\title{
OS QUINTAIS CAIÇARAS, SUAS CARACTERÍSTICAS SÓCIO-AMBIENTAIS E PERSPECTIVAS PARA A COMUNIDADE DO SACO DO MAMANGUÁ, PARATY- RJ
}

\author{
VALQUÍRIA GARROTE
}

Dissertação apresentada à Escola Superior de Agricultura "Luiz de Queiroz", Universidade de São Paulo, para obtenção do título de Mestre em Recursos Florestais, com opção em Conservação de Ecossistemas Florestais.

PIRACICABA

Estado de São Paulo - Brasil

Fevereiro - 2004 


\title{
OS QUINTAIS CAIÇARAS, SUAS CARACTERÍSTICAS SÓCIO-AMBIENTAIS E PERSPECTIVAS PARA A COMUNIDADE DO SACO DO MAMANGUÁ, PARATY-RJ
}

\author{
VALQUÍRIA GARROTE \\ Biólogo \\ Orientador: Prof. Dr. VIRGíLIO MAURÍCIO VIANA
}

Dissertação apresentada à Escola Superior de Agricultura "Luiz de Queiroz", Universidade de São Paulo, para obtenção do título de Mestre em Recursos Florestais, com opção em Conservação de Ecossistemas Florestais.

\author{
PIRACICABA \\ Estado de São Paulo - Brasil
}

Fevereiro - 2004 

Dados Internacionais de Catalogação na Publicação (CIP)
DIVISÃO DE BIBLIOTECA E DOCUMENTAÇÃO - ESALQ/USP

Garrote, Valquíria

Os quintais caiçaras, suas características sócio-ambientais e perspectivas para a comunidade do Saco do Mamanguá, Paraty-RJ / Valquíria Garrote. - - Piracicaba, 2004.

186 p. : il.

Dissertação (mestrado) - - Escola Superior de Agricultura Luiz de Queiroz, 2004.

Bibliografia.

1. Desenvolvimento sustentável 2. Ecologia humana 3. Educação ambiental 4. Proteção ambiental 5. Qualidade de vida 6. Reserva natural (Conservação) 7. Segurança alimentar 8. Uso do solo I. Título

CDD 333.707

"Permitida a cópia total ou parcial deste documento, desde que citada a fonte - O autor" 


\section{AGRADECIMENTOS}

Ao finalizar este trabalho, entre a mistura de sentimentos que me chegam, vem também a grande certeza de não tê-lo feito sozinha. Foram muitas e diferentes e valiosas contribuições... Agradecer somente, parece ser pouco diante de tudo o que foi construído, diante das descobertas que foram tantas! Todas essas pequenas, grandes contribuições, chegaram em seu melhor momento e de alguma forma colaboraram com um, ou vários tijolinhos para o que aí está... Para esta construção, de onde emana carinho e amor aos seres viventes desse planeta azul. Um momento de satisfação, de um grande alívio, por constatar que dei conta, que de alguma forma dei conta, do que me propus fazer e que antes era só uma idéia. Construir... costurar retalhos, olhares multiplicados. E então valeram as opiniões, as conversas, os abraços, as trocas, os ideais, algumas angústias, as conquistas, as dúvidas, os temores e as certezas, valeu sonhar, sempre vale! E enfim os retoques... o acabamento final, com uma imensa torcida para tudo dar certo! E agora gostaria de dividir tudo isso com as pessoas maravilhosas que cruzaram meu caminho, expressando toda minha imensa gratidão. Por tudo, por tudo mesmo...

Ao LASTROP e ao professor Virgílio Maurício Viana, por todas as oportunidades que me propiciou.

À FAPESP, pela bolsa concedida pois, sem esta seria impossivel a realização desse trabalho.

Aos professores Adriana Nolasco, Marcos Sorrentino, Carlos Rodrigues Brandão, Lin Chau Ming, Lúcia Ferreira e Vera Lex, que contribuíram com discussões e opiniões sobre o trabalho.

A todas as famílias do Saco do Mamanguá, tão queridas, tão pacientes e receptivas, que me receberam e me contaram sobre suas histórias e sobre o viver caiçara no lugar que protege. Em especial (mesmo sendo difícil dizer isso) à Dona Odete e ao Seo Licínio, Seo Jurai e Dona Gracinha, Dona Anézia, Dico e Lúcia, Isete e Neli e Gilcimar meu querido amigo.

À AMAM, por todo o apoio logístico, ao Paulo pela hospedagem e algumas dicas iniciais, mas em especial ao Alecir e Valdemir, por sempre estarem presentes e prontos para ajudar e ouvir. À minha família, Nonninha, titio, Vivian, meus queridos irmãos e suas famílias que tanto amo, pelo apoio e pelo respeito ao meu trabalho, aos meus ideais e aos aprendizados conjuntos. 
À minha família que a vida generosamente me ofereceu, meus irmãos e irmãs Marcinho, Marcus, Laurão, Renata, Marina e Fernanda, que repartiram a mesma casa, o mesmo quintal, tantas histórias, (Miró e Chuva e Nina) e descobertas juntos.

Na verdade esta família que a vida me ofereceu e oferece é extensa...Não apenas nuclear...e aí são muitos os nomes a serem ditos: Glaucinha e Thalissa (queridas), Clebinho e Elektra, Luiz Fernando, Calú, Pati Girl, Dáda e Bibelô, Mariana, Isa e Natália..

'A família Mutirão, tão especial, por tantos motivos, mas principalmente por me fazer sempre acreditar em nosso trabalho, por sempre, sempre renovar minhas esperanças na vida e no amor pelo Planeta Terra.

Ao Ney França por todo apoio e carinho em Paraty.

Ao Fabrício Tinto pela boa companhia no trabalho de campo e sua preciosa ajuda na confeç̧ão dos croquis e no levantamento botânico.

Ao Beija-flor, pela grande ajuda na organização dos dados no Access.

Aos técnicos, estagiários e pós-graduandos do Herbário da ESALQ e aos professores Vinícius de Castro Souza e Lindolfo Capellari Júnior, pelo grande apoio na identificação do material botânico. Ao Rawson e à Mônica Stein na confecção do calendário das fruteiras.

Não posso deixar de mencionar o Alexandre, Ivo, Evandro e Higor, que sempre estiveram prontos para nos ajudar nas pequenas e às vezes em coisinhas bem complicadas de serem resolvidas.

À Paula e o Cláudio do CALQ, pela grande força na hora de passar do virtual para o real!

À todos os amigos e amigas da pós, "das antigas", Neném, Dri, Carlinha, pelas boas lembranças e a turminha de agora... Ás Claúdias (Lira, Coelho e Irene) Marcelino, Andréa Mosca, Raquel Wirifran, Pati,... e...

Aos amigos e amigas I da OCA, (TOD@S!) por todas as idéias, e sonhos repartidos.

Ao Plácido e Renata por terem me oferecido um espaço tão especial para concluir o trabalho e todo carinho e apoio.

E por fim ao meu amorzinho Gleyson, meu grande companheiro, e que esteve tão presente acompanhando, compartilhando a vida nesse último ano.

Obrigada. 
À persistência, à fé das pessoas que ainda resistem, insistem em ser felizes diante do simples viver.

Às pessoas que ainda resistem, insistem, acreditam e acima de tudo, lutam com 0 coração.

E como diria Doroty Marques:

"Chegou a hora de quem trabalha com a emoção". (Que a hora seja AGORA, do ser humano ser enfim parte e não estar à parte da divina teia). 


\section{SUMÁRIO}

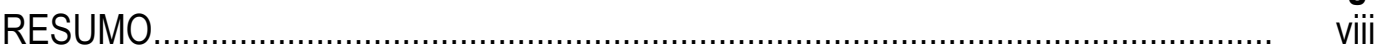

SUMMARY

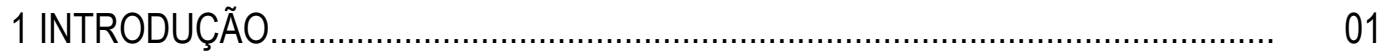

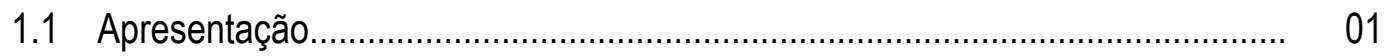

1.1.1 O desafio de contar histórias........................................................................... 03

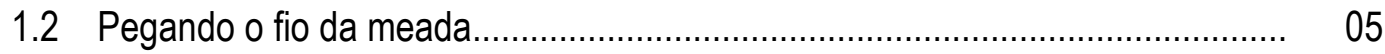

1.3 Os Atores principais - os caiçaras do Saco do Mamanguáa............................... 12

1.3.1 Populações tradicionais e a legitimidade de Estar vivendo em uma unidade de conservação.

1.3.2 A construção e desconstrução de uma identidade- Ser Caiçara........................... 14

1.4 A Roça e os quintais - caminhos paralelos rumo a alternativas frente à condição sócio-ambiental de populações em unidades de conservação.

1.41 A Roça caiçara ....................................................................................... 18

1.4.2 Os quintais agroflorestais ............................................................................... 21

1.4.3 A dieta caiçara e 0 uso das roças e quintais..................................................... 23

1.5 Objetivo da pesquisa.............................................................................. 25

2.0 LOCAL DE ESTUDO E O RECORTE METODOLÓGICO.................................. 26

2.1 A Escolha do lugar, tudo tem um início............................................................. 26

2.20 cenário que se apresenta....................................................................... 28

2.3 O Recorte metodológico................................................................................ 31

2.3.1 Os procedimentos metodológicos e suas bases teóricas................................... 31

2.3.2 A escolha dos quintais estudados na comunidade do Saco do Mamanguá....... 34 


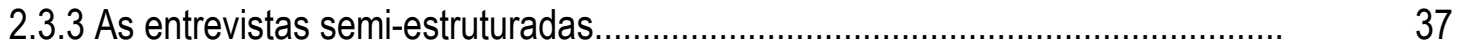

2.3.4 Levantamento etnobotânico........................................................................... 40

2.3.5 Confecção de perfis, croquis e levantamento das áreas dos quintais................. 41

2.3.6 Calendários das fruteiras................................................................................

2.3.7 Levantamento da dieta familiar........................................................................... 46

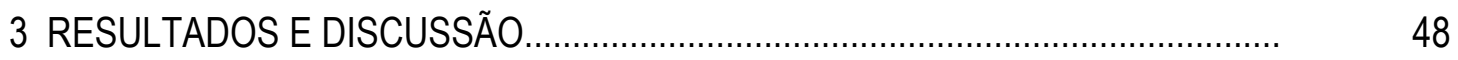

3.1 No Vai e vem das águas do mar - diferentes tempos a desvendar.................... $\quad 49$

3.2 O tempo da fartura, o tempo de agora e a roça no Saco do Mamanguá............. 50

3.1.2 A mesma estrada que leva, traz (...) .......................................................

3.1.3 O que trouxe o turismo............................................................................. 57

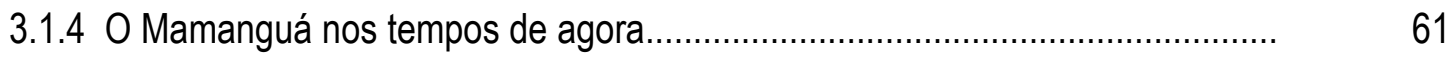

3.2 OS QUINTAIS CAIÇARAS DO SACO DO MAMANGUÁ....................................... 69

3.2.1 As Diferentes visões dos quintais: o êmico e o ético........................................... 70

3.2.2 Um Primeiro reconhecimento.....................................................................

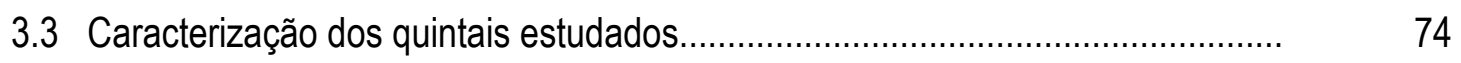

3.3.1 Caracterização sócio-econômica....................................................................

3.3.2 Caracterização etnoecológica.......................................................................

3.3.3 A presença de veranistas e seus quintais......................................................... 124

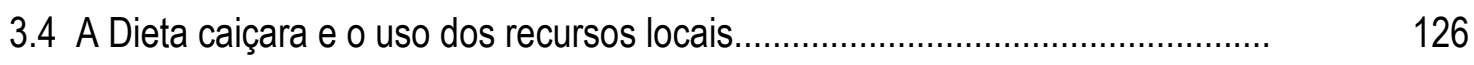

3.4.1 Algumas reflexões sobre as técnicas aplicadas durante o trabalho de campo- 134 Os problemas encontrados e suas adaptações.

3.4.2 Um pouquinho do sabor dos produtos que vem do quintal.............................. 137

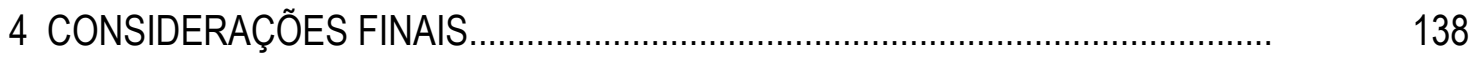

ANEXOS

REFERÊNCIAS BIBLIOGRÁFICAS ...................................................................... 179 


\title{
OS QUINTAIS CAIÇARAS, SUAS CARACTERÍSTICAS SÓCIO-AMBIENTAIS E PERSPECTIVAS PARA A COMUNIDADE DO SACO DO MAMANGUÁ, PARATY- RJ.
}

\author{
Autora: VALQUÍRIA GARROTE \\ Orientador: Prof. Dr. VIRGÍLIO MAURÍCIO VIANA
}

\section{RESUMO}

Esta dissertação teve como objetivo caracterizar e analisar dezenove quintais caiçaras na comunidade do Saco do Mamanguá, localizada no município de Paraty - RJ, do ponto de vista social, econômico e etnoecológico em estreita associação com os fatores externos de pressão presentes no contexto regional. A orientação metodológica adotada seguiu os princípios da pesquisa-intervenção em combinação com métodos e técnicas utilizadas nas ciências sociais, etnoecológicas e diagnósticos participativos. Os atuais e principais fatores de pressão vivenciados por esta comunidade são parte de um processo histórico, que teve início, principalmente, com a abertura da estrada Rio-Santos, cujo maior impacto foi o estímulo ao turismo na região, tendo como conseqüência direta o avanço da especulação imobiliária, contato crescente das comunidades caiçaras com centros de consumo, extração predatória de plantas com valor econômico e a criação de Unidades de Conservação na região, como uma medida de proteção. 
Estes fatores foram analisados do ponto de vista de seus impactos sociais, econômicos ambientais e culturais na reorganização dos sistemas tradicionais de produção e manejo dos recursos naturais da comunidade do Saco do Mamanguá, com enfoque no uso da terra, em especial, nos sistemas de produção quintais. Uma das conseqüências mais evidentes foi a perda de território e de mobilidade interna dos grupos familiares, resultando na diminuição dos espaços para plantios - roçados e quintais - e, por fim, na delocalização alimentar e aumento da dependência de produtos externos. Embora os itens alimentícios comprados na cidade representam $60,2 \%$ do total de alimentos citados nos levantamentos, os recursos locais ainda contribuem com $39,7 \%$ dos itens alimentares, sendo que $13,7 \%$ são provenientes dos quintais, que oferecem, principalmente, frutas e, em menor quantidade, verduras, plantas medicinais e condimentares. Isso mostra a importância dos quintais para a segurança alimentar das famílias. Nos dezenove quintais estudados foram encontradas 347 espécies, com uma média de 64 espécies por quintal, evidenciando sua riqueza em diversidade. Outro aspecto importante observado foi complexidade da estrutura dos quintais. Em todos eles foram observados três principais estratos: o estrato herbáceo com predominância de plantas ornamentais; o estrato arbustivo com espécies destinadas, principalmente, à alimentação e o estrato arbóreo, composto por espécies frutíferas e nativas, cujo ambiente sombreado produzido determina as demais espécies dos estratos inferiores, que, em geral, são espécies perenes, pouco exigentes em manejo e luminosidade e destinadas principalmente à alimentação. Considerando que os quintais são sistemas complexos, cujos fatores influenciam na sua forma, função e manutenção, foram observadas diferentes zonas de manejo. Ao caracterizar os quintais procurou-se enfatizar suas funções e valores, incluindo aqueles reconhecidamente intangíveis, dificilmente mensuráveis, ligados ao valor estético, ao lazer e ao aspecto emotivo. Isso permitiu dar visibilidade à contribuição dos quintais para a qualidade de vida das famílias e para a segurança alimentar e, através desses valores e dos sistemas de manejo já praticados, incentivar, futuramente, a formulação de novas práticas agroflorestais em sintonia com os princípios do desenvolvimento sustentável para a região. 


\title{
HOMEGARDENS, THEIR SOCIAL AND ENVIRONMENTAL CHARACTERISTICS AND PERSPECTIVES FOR THE SACO DO MAMANGUÁ COMMUNITY, PARATY-RJ.
}

\author{
Author: VALQUÍRIA GARROTE \\ Adviser: Prof. Dr. VIRGÍLIO MAURÍCIO VIANA
}

\section{SUMMARY}

This dissertation had the objective of characterizing nineteen homegardens in the Saco do Mamanguá community, located in the Paraty County - RJ. Social, economical and ethnoecological aspects were addressed in close association with external pressure factors in the regional context. Research-intervention methodology was used, as in social sciences, ethnoecology and participatory diagnosis. Present and main pressure factors affecting this community are part of a historical process, that started with the opening of the Rio-Santos highway. Its biggest impact was the stimulus for tourism, causing the expansion of real estate exploitation, constant contact of the local people with urban centers, predatory extractions of economically valued plants and the creation of Conservation Units in this region, as a means of protection. These factors were analyzed from the stand point of the social, economical, environmental and cultural impacts on the reorganization of the traditional production systems and natural resource management at the Saco do Mamanguá, focusing land use, and specially homegardens. 
One of the most evident consequences was the loss of territory and internal mobility of the families, resulting in the decrease of land for cultivation - gardens and fields of plantation - and at last, the food delocalization and increase of dependence on external products. Although food bought in the city represent $60.2 \%$ of the total cited in the surveys, local resources contribute with $39.7 \%$, from which $13.7 \%$ come from homegardens, which supply mainly fruits and in less quantity vegetables, medicinal plants and condiments. These data show the importance of home gardens in the families' food and health supply. Besides, from the 19 home gardens studied, we found 347 species of plants, with an average of 64 species per garden, showing their richness in diversity. Another important aspect was the structural complexity of these gardens. All of them presented three main strata: herbs (dominated by ornamental plants); shrubs (mostly for food); and trees (dominated by fruits) in which shades are occupied by other perennial species. Considering that these gardens are complex systems, one can observe different zones of management. While characterizing these gardens, their function and values were emphasized, including the intangible ones, hardly measured, related to esthetical values, to leisure and to emotional aspects. These aspects give visibility to the gardens' contribution to life quality of those families and their health security, and through these values and the management systems already in practice, to stimulate in the future the formulation of new agroforestry practices that are in tune with the principles of sustainable development. 


\section{Introdução}

\subsection{Apresentação}

Entre as duas maiores cidades brasileiras (Rio de Janeiro e São Paulo) situa-se o Saco do Mamanguá no extremo litoral sul fluminense. Em uma pequena porção da Floresta Atlântica, banhada por águas infinitamente azuis-esverdeadas, vivem famílias que ainda praticam a pesca de subsistência, cultivam suas roças de mandioca, fabricam a farinha e com menor intensidade, praticam a pequena caça, o que caracteriza o modo de vida tradicional caiçara (Diegues e Nogara, 1994). Este lugar de grande beleza ambiental e por que não dizer social, é mais um entre os incontáveis palcos por este Brasil afora, que exibe a mesma história, às vezes com coincidentes papéis. A história que me atreverei a contar, tem como pano de fundo um dos dilemas humanos atual (entre tantos outros): a preservação dos recursos naturais, através da criação de Unidades de Conservação, versus, o direito à permanência e ao acesso a esses recursos por populações presentes em seus limites ${ }^{1}$, assim como a percepção destes recursos por diferentes culturas que inevitavelmente e, cada vez mais, se chocam e interagem.

\footnotetext{
${ }^{1}$ Um estudo realizado pelo NUPAUB, mostrava que em cerca de $74 \%$ das unidades de conservação restritivas do Estado do Rio de Janeiro tinham populações vivendo em seu interior, (Vianna, Adams e Diegues, 1994, citado por Diegues e Nogara, 1994), este número sobe para mais de $80 \%$ na América do Sul (Borrini-Feyrabend, 1997 e Brito, 2000). E ainda, como afirma Rodrigues, (2000, p.14) em sua tese de doutorado, no que chamou de Cenário Principal: "A crise ambiental mundial encontra-se entre os principais desafios a serem enfrentados na contemporaneidade, tendo em vista um futuro melhor par todos. Todavia, ainda que as fronteiras das injustiças sociais alarguem-se assustadoramente, vezes sem fim, o limite da sustentabilidade ecológica em nível planetário pode, certamente, chegar a um ponto intransponível, ameaçando a própria sobrevivência da vida na Terra”.
} 
Dentre os significados que me apresentaram sobre o nome "Mamanguá", um me chamou a atenção: "o lugar que protege". E por isto comecei a pensar sobre o significado de espaço e lugar. Ao tratar sobre este tema, espaço e lugar, Tuan (1983) afirma que estes freqüentemente se fundem na realidade, e à medida que o espaço abstrato é melhor conhecido torna-se o lugar, o lugar seguro e dotado de valores. Nesse sentido, a percepção dos conceitos de espaço e lugar poderia ser utilizada como uma boa ferramenta nas discussões e no entendimento sobre 0 uso dos recursos e do estar vivendo em Unidades de Conservação, como é o caso desta comunidade. Partindo desta idéia cheguei ao lugar mais próximo das pessoas, aos seus quintais, que também são entendidos como a continuação da casa (Lok, 1996). Os quintais são classificados como um tipo de sistema agroflorestal que apresenta íntima associação entre árvores e arbustos de uso múltiplo, com cultivos anuais, e perenes, animais, no terreno próximo à moradia, cuja mão-de-obra é familiar (Nair, 1993).

Com a proposta de caracterizar os quintais ou os "terreiros" como um sistema de produção complementar a outras formas de uso da terra (a roça e a floresta), bem como a outras atividades, busquei perceber, destacar valores ou funções deste sistema, deste lugar.

Ao focalizar o quintal e a partir deste sistema de produção, com a análise dos resultados, reuni subsídios para discutir o contexto sócio-ambiental mais amplo no qual estão inseridos os grupos familiares. Procurei valorizar o quintal como um componente importante para qualidade de vida destas famílias ao ressaltar o valor de uso alternativo da terra em comunidades rurais, com relativo isolamento dentro de Unidades de Conservação na Floresta Atlântica e dependentes dos recursos locais.

A partir da percepção do lugar ou dos lugares que se compõem ou da construção destes por pessoas, quis provocar, através da sistematização dos dados que obtive durante a pesquisa, a discussão dos valores implícitos e explícitos dos quintais. Essa discussão se iniciou com 0 reconhecimento do espaço próximo a casa e se estendeu ao entorno. Seguiu por entre as relações mantidas por esta comunidade diante do contexto no qual encontravam-se os diferentes atores e pessoas que representam uma determinada cultura ainda resistente nos interstícios da Floresta Atlântica. 
A discussão perpassa pelo entendimento do "Ser" e "Estar". O ser caiçara e o estar vivendo em Unidades de Conservação. Em ser 0 agente que possui o conhecimento sobre 0 lugar e formas tradicionais de uso dos recursos. Por último, ser o agente político ao reconhecer uma identidade conferida, que lhes permite o direito de estar no lugar, o lugar que protege.

"Convido-os a entrar nos quintais, "terreiros" do Saco do Mamanguá..." É só ir chegando, pois não tem cercas, nem muros, tem é muita fruteira espalhada e claro muita, muita flor... Chegamos ao lugar desta gente simples que me recebeu de portas e corações abertos para contar suas histórias e do seu lugar, onde ainda o sossego era o motivo de orgulho, misturado com uma certa dor de esquecimento.

Eu entrei não somente em seus quintais, mas dentro de suas casas e vidas e não falei somente do plantar, do colher e do comer2, mas falei com os olhos e com as almas das pessoas.

\subsubsection{O desafio de contar histórias...}

Como começar? Essa pergunta esteve dentro de mim por muito tempo.

Era só isto que conseguia pensar. Permaneci por um tempo estática diante de meus pequenos (grandes) desafios, diante de todas as informações e vivências. A procura de caminhos seguros para contar as histórias de pessoas vivenciando o seu tempo. Perceber esse tempo e quais eram os personagens e seus papéis, e por fim, como estes personagens compunham o seu cenário?

Sem querer, ou somente dando vazão à intuição, comecei a desvendar estes caminhos no próprio processo de escrever... E desde o início ao apresentar o tema, sem que realmente me desse conta, esta foi a dica: o "palco" e seus personagens. Contar uma história, ou melhor, histórias a partir de flores, de cheiros, de fruta mordida, de criança comendo goiaba, a história assim percebida que ganha vida, no momento em que a conto.

Outros pensamentos me vinham insistentes... Sabia das minhas limitações como bióloga, na tentativa de interpretar fatos e fatores sociais. Mas também tinha a consciência que em minhas mãos ou em algum lugar dentro do meu ser estavam as palavras e toda a síntese das histórias que eu gostaria de transmitir ao papel... Agora não seria mais com o auxílio da caneta 
ou do lápis, nem da mão de minha nonna, quem me ensinou a desenhar, lembro até do cheiro do papel de pão, no qual brincávamos de desenhar casinhas e quintais com árvores que davam frutos e onde morava uma família, e que poderia ser a minha. A representação em desenhos sempre me tocou, assim como falar ao papel, meus "sentires"... como então poderia ser tão difícil escrever, se sempre foi assim?... Sempre foi aqui que pude me encontrar e falar ao vento desafiando o tempo histórias de mim mesma, histórias que eu presenciava com o resto do mundo e que aos poucos ia descobrindo na minha meninice, na minha adolescência e por fim na tentativa de me tornar mulher. Agora não há mais lápis ou canetas para me apoiar, para não cair no abismo da minha eterna angústia de viver... Há o teclado dos tempos modernos, tempos de transição, que em sua velocidade, mal damos conta de vivenciar.

Como transitar entre a linguagem científica e a minha forma de escrever, como expressar, informar, discutir, não de forma fria e puramente descritiva e sim com o sabor do café, dos bolinhos de chuva, ou com os pingos da chuva, os mergulhos em meio a ardentia? Como não dizer dos olhares, que sempre olharam curiosos e, vez ou outra, mãos que se agarravam à minha, me seguiam pelos caminhos e mexiam em meus cabelos? Como não falar dos sorrisos tímidos, da simpatia e acolhimento de todas as famílias, das flores, das orquídeas, presentes nos quintais? E deixar de lado as histórias que contam os acontecidos de um tempo não tão distante, no qual essas famílias muitas vezes foram protagonistas?

Descobri que eu podia ousar a escrever e ser assim, exatamente assim, sem perder toda a seriedade acadêmica como me é, afinal, exigido e foi assim que me reconheci, ao escrever misturando as metáforas e figuras de linguagem, para não falar apenas de ciência, mas falar de sentimentos que muitas vezes ficam restritos a um rodapé invisível. $E$ assim percebi que tudo fluía como música, porque era assim meu jeito de ser e assim que conseguiria me comunicar com o mundo externo.

\footnotetext{
${ }^{2}$ Alusão ao título do livro de Carlos Rodrigues Brandão, 1981.
} 


\subsection{Pegando o fio da meada}

A história do Mamanguá e das pessoas que lá vivem já foi de alguma forma contada, inúmeras vezes, pois a história do litoral brasileiro se repete, ou pelo menos em parte dele. Muitos foram os autores que caracterizaram o modo de vida dos caiçaras e a relação destes com os recursos próximos. Descreveram o conhecimento que surge como conseqüência de muitos anos desta relação, sua importância, assim como os mitos e a simbologia que emergiram dentro desta cultura. E claro, as injustiças e os fatos históricos que marcaram estas populações, também já foram temas de muitas pesquisas, livros, que descreveram a cultura caiçara e que denunciaram o avanço da destruição, não só da Floresta Atlântica e dos recursos marinhos, mas a degradação cultural, como conseqüência das ações da sociedade urbana-civilizada, movida pela lógica capitalista 3 .

E para contar essa história a partir da perspectiva do meu olhar e da minha vivência, iniciei "pegando o fio da meada" no livro referência, publicado na década de noventa, "Nosso Lugar Virou Parque"4 de Diegues \& Nogara (1994) e que foi escrito com base em um estudo realizado no Saco do Mamanguá. É a partir deste livro que situei essa pesquisa dentro de um contexto histórico do lugar citando os fatos mais recentes que foram vivenciados por esta comunidade (década de 40-50).

$\mathrm{Na}$ introdução do livro, os autores fazem alguns apontamentos que também foram observados, discutidos e constituem o problema de pesquisa levantado nesse trabalho. Os autores avaliaram as mudanças na organização dos sistemas de produção e na utilização dos recursos pela população local e suas causas. Com isso, busquei identificar e entender se os fatores sócio-ambientais externos a esta comunidade afetaram e afetam as formas de uso da

3 Existem inúmeros autores que desenvolveram suas pesquisas sobre populações caiçaras, aqui vou citar apenas alguns, os quais, a maioria, consta no corpo do texto: França, 1951; Mussolini, 1980; Mourão, 1971; Diegues, 1983, 1994; Siqueira, 1984; Maldonado, 1986; Begossi,, 1989; Kempers, 1993; Mansano, 1998; Rodrigues, 2000, entre muitos outros.

4 Este livro é resultado de um dos estudos realizados pelo então CEMAR (Centro de Culturas Marítimas da Universidade de São Paulo, atual NUPAUB-Núcleo de Pesquisa sobre Populações Humanas e Áreas Úmidas) no início da década de 90 em conjunto com o Departamento de Antropologia da Universidade de Laval-Canadá, que teve como objetivo fornecer subsídios ao conhecimento da área estuarina e de Mata Atlântica que foi transformada em Reserva Ecológica em 1992 e onde parte peninsular do Saco do Mamanguá está inserida, (Diegues \& Nogara, 1994). 
terra, em especial o sistema de produção quintal, em comunidades inseridas nos limites e dentro das Unidades de Conservação, como é o caso da comunidade do Saco do Mamanguá.

As atividades tidas como tradicionais submetidas direta e indiretamente a esses fatores podem ser substituídas e afetadas gradativamente, inclusive pela própria dinâmica interna entre e dentro dos grupos com interesses próprios que se posicionam diante de situações diversas e disputas de poder.

É possivel identificar através de uma breve revisão histórica os fatos ou os elementos que corroboraram para as mudanças e como estas foram desencadeadas e em quais momentos ocorreram na comunidade do Saco do Mamanguá

Ao descrever as populações caiçaras, Mussolini (1980) aponta o relativo isolamento geográfico destas e um desenvolvimento de vida fechada, porém sujeitas em diferentes graus aos processos sócio-econômicos e mais recentemente, diria-se também aos processos sócioambientais e a comunidade do Saco do Mamanguá não foge a esta situação.

Antes, porém, gostaria de abordar a questão sobre tradição e moderno e as rupturas dentro do aspecto dinâmico das culturas. É possível realizar paralelos entre as culturas caiçara e caipira, tanto no que diz respeito às suas origens étnicas e o desenvolvimento de suas estruturas, quanto aos fatores de mudança e pressão sob as quais estão submetidas. No livro "Os Parceiros do Rio Bonito" Antonio Candido (1987), ao descrever a cultura caipira apresenta a situação de mudança em relação à anterior, na qual é assinalada a passagem duma economia auto-suficiente para o âmbito da economia capitalista. Realiza a análise da mudança através da manifestação de sintomas, aos quais se refere como crise social e cultural e o processo desencadeado que pode levar à manutenção, ou à ruptura e reinvenção dos seus aspectos culturais. Segue abaixo um trecho do livro que expressa essa situação:

"Em toda conjuntura de crise podem-se observar duas categorias principais de fatos: os de persistência e os de alteração. Os primeiros constituem aquela parte do equipamento cultural e das formas sociais que, oriundas de período anterior, perduram no presente, estabelecendo continuidade entre sucessivas etapas dum processo total de transformação. Os segundos são formações novas, geradas no seio do grupo, ou nele incorporadas por difusão, para reajuste do seu funcionamento. Todo equilíbrio social - essencialmente dinâmico - supõe estes dois aspectos. Diz-se, todavia que há mudança quando nas variações de equilibrio, os fatores de 
alteração avultam, até motivarem recomposição de estrutura. A situação da crise define-se, do seu lado por tensões ainda não resolvidas, ou resolvidas parcialmente, entre os fatores de persistência e os de alteração podendo originar reorganização ou desorganização mais ou menos profundas da estrutura", (Candido, 1987, p.163-164).

Retornando ao livro "Nosso Lugar Virou Parque", Diegues e Nogara (1994) assinalaram que a primeira mudança ocorrida em relação aos sistemas de produção nas comunidades caiçaras, e em específico no Saco do Mamanguá, ocorreu com a chegada das traineiras e da pesca embarcada. Neste momento, a agricultura e a pesca de subsistência passaram de atividades principais à secundárias e a responsabilidade por estas atividades foi assumida pelas mulheres e crianças. Com isto, os homens, principalmente os jovens, deixaram suas famílias e as atividades locais para praticarem a pesca marítima e passavam a maior parte do tempo embarcados, exceto nos períodos de claro (épocas de lua cheia) e nas épocas do defeso.

A segunda grande mudança que chegou inicialmente tímida, no caso do Mamanguá pelo difícil acesso, se deu com a chegada dos veranistas e turistas. Sobretudo após a abertura da BR 101 (Rio- Santos), que facilitou a chegada a esta parte do litoral, aumentando a especulação imobiliária nesta região de grande beleza cênica.

Por último, é citada a criação das Unidades de Conservação, em especial a da Reserva Ecológica da Juatinga- REJ em 1992 que atingiu não somente o Saco do Mamanguá, mas envolveu diferentes comunidades. Os autores dão certa relevância às restrições impostas pela legislação ambiental, a partir de sua criação. Relevância esta, totalmente pertinente no momento em que o livro foi publicado, tendo um peso maior nessa época do que nos dias atuais, no caso do Saco do Mamanguá, pois tinham como exemplo pungente e vivo, o Vale do Ribeira - SP, que no início da década de oitenta foi palco de muitos conflitos entre diferentes atores diante da implantação verticalizada de Unidades de Conservação (Ferreira et al., 2000). É citado ainda pelos autores, que apesar de todos os aspectos negativos que poderiam afetar diretamente as populações residentes na REJ, a criação deste tipo de Unidades de Conservação, teria um aspecto positivo, que seria a contenção da especulação imobiliária crescente nesta região.

Contudo, o que se observou, após oito anos da publicação da primeira edição do livro "Nosso lugar virou Parque", é que a aplicação da legislação ambiental, que poderia ser um dos fatores que contribuiria na desestrutração destas comunidades, não se concretizou efetivamente, 
já que o órgão responsável por esta Unidade de Conservação,- Instituto Estadual de Florestas IEF, se fez presente em Paraty apenas a partir da metade da década de noventa contando apenas com um funcionário.

A REJ sobrepõe-se à Área de Proteção Ambiental - APA do Cairuçu, e abrange uma extensa área na qual, além de parte peninsular do Saco do Mamanguá, são incluídas mais onze comunidades com diferentes características e incontáveis problemas e conflitos. Não houve esclarecimentos a respeito da criação desta Unidade de Conservação e nem mesmo, como está previsto na legislação da REJ5, programas de educação ambiental envolvendo as populações locais, que permitissem a valorização da cultura e a utilização dos recursos de forma planejada, mediante a um plano de gestão.

Diferente do que aconteceu no Vale do Ribeira-SP, no final da década de 80 e início dos anos 90 palco de muitos conflitos diante da criação verticalizada de muitas unidades de conservação com uso restrito (Ferreira et al., 2000), a população continua residindo em "seu" lugar, utilizando os recursos sem sofrer o impacto de uma fiscalização mais severa. Isso ocorre em parte pela falta de estrutura de fiscalização do órgão administrativo e também pelo respaldo encontrado na própria lei que regulamenta a REJ, no que tange à cultura caiçara. Observa-se, ainda hoje, a manutenção de atividades tradicionais coexistentes ou adaptadas às novas atividades ligadas diretamente ou indiretamente ao turismo. A utilização da caixeta- Tabebuia cassinoides, uma árvore de madeira leve e fácil de manusear para a fabricação de peças de artesanato que são vendidas em Paraty, Angra dos Reis e outras cidades turísticas- é um exemplo de atividade tradicional que se adapta ao novo contexto, no qual o conhecimento tradicional é integrado a uma nova realidade: o turismo. No Saco do Mamanguá existem aproximadamente 50 artesãos que se ocupam especialmente do artesanato na época da "safra" do turismo. Ainda há pessoas na comunidade que usam a taquara e cipós na fabricação de

\footnotetext{
${ }^{5}$ Foi criada pelo Decreto Estadual no 17.981 , de 30 de outubro de 1992, com o objetivo de preservar o ecossistema local, composto por remanescentes florestais de Mata Atlântica, restingas, manguezais e costões rochosos, além de tentar preservar a típica cultura caiçara. A área da Reserva, com cerca de 8.000 hectares (80 quilômetros quadrados), abriga doze núcleos de ocupação de populações tradicionais, que se distribuem em trechos ao longo do litoral e vivem de pesca artesanal, agricultura de subsistência, e mais recentemente, do turismo que vem sendo o causador de um forte processo de descaracterização cultural. Os núcleos se relacionam entre si e usam a cidade de Paraty como centro de comércio e serviços, apesar da precariedade de acesso - a pé, por picadas, ou barcos, (www.ief.rj.gov.br, acessado em 25/03/2003).
} 
tapitis e balaios (utilizados na confecção de farinha de mandioca) e a palha do coco preto para fazer abanos, também comercializados em lojas nas cidades em Paraty. As poucas canoas que ainda são esculpidas em troncos de espécies nativas (como a timbuíba, cedro, ingá, carquera, caixeta, etc) são retiradas da floresta próxima, assim como diferentes tipos de madeiras utilizadas na construção e reparos de casas, embarcações, cais e outras benfeitorias. As áreas de roças diminuíram drasticamente, porém ainda existem famílias que cultivam a mandioca para a confecção de farinha. A caça, embora com menor freqüência, se faz ainda presente na dieta do caiçara. Mas, se estas atividades são entendidas como constituintes do arcabouço da cultura caiçara, estão previstas dentro da lei que criou a REJ, assim como sua preservação é incentivada. $O$ que não acontece no caso das construções de casas de veranistas. Portanto, 0 que se percebe é que a criação da REJ foi mais um exemplo de Unidades de Conservação de papel, que inclusive a contenção da especulação imobiliária, uma das justificativas de sua criação, também ficou somente no papel, pois o que se vê "a olhos vistos", é o aumento de construções de casas de veranistas.

Atualmente com a aprovação do Sistema Nacional de Unidades de Conservação, em julho de 2000, a REJ torna-se uma categoria inexistente dentro deste sistema. O IEF até 0 momento demonstra-se propenso à reclassificação da REJ em Parque Estadual. Com esta atitude mostra-se, mais uma vez, indiferente e insensível às populações locais, às suas necessidades, e à história e suas contribuições para a conservação dessa região6 .

Caso a REJ venha a tornar-se um Parque Estadual, as populações locais deverão ser retiradas, indenizadas e assentadas em outras regiões, (SNUC, 2000). O local será destinado à visitação pública, enfim ao turismo, beneficiando uma pequena parcela da população elitizada. Uma pequena parte do paraíso de águas transparentes e azuis, preservada para quem afinal? E

6 Esta posição assumida pelo IEF-RJ parece ignorar a crise enfrentada pelos Órgãos Ambientais responsáveis pelas Unidades de Conservação, como é assinalado por (Diegues, 2001) em Saberes Tradicionais e Etnoconservação "As áreas protegidas brasileiras, em particular as de uso indireto (Parques Nacionais, Reservas Biológicas, etc) estão em crise, muitas estão sendo invadidas e degradadas. Para os defensores do modelo norte-americano de parques sem habitantes, as razões de tal crise, são em geral, ligadas à falta de dinheiro para a desapropriação, a falta de investimento público, de fiscalização e de informação aos visitantes público. Para os que defendem outras alternativas de conservação, essas dificuldades são inerentes ao modelo atual predominante nas áreas protegidas, uma vez que, tendo sido criado no contexto ecológico e cultural norte-americano, não se aplica ao contexto dos países tropicais do Sul”. 
que até então foi conservada por populações caiçaras, através de formas diferenciadas de produção e interação com os recursos naturais presentes.

Portanto, a legislação ambiental, que até então não representava uma limitação real, transforma-se em uma ameaça constante e que, por sua vez, desencadeia uma situação de instabilidade, medos e uma série de conflitos envolvendo os diferentes atores ou interessados, externos e internos. A ameaça de reclassificação da REJ, aliada ao grande interesse turístico e à especulação imobiliária, representa hoje os principais fatores externos de instabilidade e fortes pressões nesta comunidade e que serão aprofundados nos resultados.

Os atuais e principais fatores de pressão externa foram citados como parte de um processo histórico que tiveram início, principalmente, com a abertura de estradas, sobretudo a BR 101,7 com conseqüente avanço da especulação imobiliária, do turismo, da extração de plantas com valor econômico, resultando também em um contato crescente com centros de consumo. E por fim, culminaram na criação de diferentes Unidades de Conservação.

Esses fatores, acima mencionados, resultam na desorganização ou na readaptação de atividades relacionadas aos sistemas de produção e manejo dos recursos naturais em comunidades caiçaras, como no Saco do Mamanguá. $O$ abandono e a substituição de atividades tradicionais, ou ainda, a subtilização de sistemas de produção como os quintais, podem ser uma das conseqüências do relacionamento direto e indireto com turismo e ainda o aumento da aquisição e dependência de produtos industrializados, já que o poder aquisitivo também se elevou por parte de algumas famílias. Repensar essa situação e propor a discussão sobre alternativas de manejo dos recursos pelas populações residentes em unidades de conservação, se faz necessário. É fundamental que estas alternativas sejam condizentes com a vocação natural da região em questão e, ao mesmo tempo, atendam às atuais necessidades destas comunidades. A partir da concepção de que o agroecossistema é um produto da intervenção do

\footnotetext{
7 "Os faróis do trator mais pareciam os olhos de Boitatá. As crianças, que nunca tinham visto coisa igual, se encolheram junto `a saia das mães, que também olhavam o monstro assustadas. Sob o impacto da pesada máquina, troncos de jequitibás, perobas e massarandubas centenárias iam tombando um a um. Em poucas horas acontecia o que pareceu o prenúncio do fim do mundo para os caiçaras. A ocupação secular de gerações não destruíra o que o loteamento ou a estrada conseguiam em poucas horas. E o caiçara que vivera isolado, com sua economia de consumo e com seus costumes e valores próprios, viu-se de repente inserido numa outra sociedade, sem saber o que significava e sem estar preparado para ela”. Este trecho transcrito do livro Genocídio dos Caiçaras, de Priscila Siqueira (1984, p. 13) e se refere à abertura da BR 101 na década de 70.
} 
agricultor no ambiente, torna-se essencial a análise dos aspectos sociais e econômico, assim como a percepção do produtor em ao seu entorno natural, (Weid, 1995). Portanto, procurei entender os quintais como reflexo de um conjunto de fatores que determinaram ou determinam as ações de seus moradores nesse espaço.

No Saco do Mamanguá, os atores coletivos são representados pelos moradores, pela Associação de Moradores e Amigos do Mamanguá-AMAM, por instituições governamentais (IBAMA, IEF e Prefeitura Municipal de Paraty), veranistas e proprietários de sítios e pela Universidade de São Paulo, representada pelo LASTROP-ESALQ/USP e NUPAUB-USP8. Esses atores possuem graus diferentes de parcerias e relações e cada qual acredita assumir uma função para com o lugar e para com as pessoas, com expectativas e interesses específicos, que por vezes convergem e lou divergem entre si.

O que está em discussão, e o desafio que se apresenta à sociedade, representada por este grupo de atores, é como conciliar a conservação dos recursos naturais das Unidades de Conservação estabelecidas, com a presença humana e ainda proteger os ecossistemas, garantindo qualidade de vida às populações locais presentes.

Isto não significa que estas populações tenham que continuar à margem como até então estiveram: em um primeiro momento, marginalizado em relação ao mercado formal e, em um segundo momento, pressionadas pelas leis ambientais. Os fatos e as mudanças devem ser incorporados e "digeridas" através da promoção de fóruns de debates entre os interessados, nos quais discutam as alternativas de uso da terra e dos recursos marinhos. Alternativas estas que também sejam desenvolvidas com base no conhecimento acumulado pela população local em suas atividades tradicionais e, aqui me remeto novamente a Candido (1987), ao perceber os aspectos de persistência e os de alteração na dinâmica cultural. Cabe dizer que é ainda preciso aprofundar o debate em torno do conceito "tradicional", pois como afirma Britto, (1995), muitas pesquisas posicionam-se de forma estática frente às mudanças que podem ser relativizadas em seus aspectos positivos e negativos diante de um determinado grupo social. Esse autor discorre que muitos pesquisadores assumem uma posição rígida e simplificada entre tradição e mudança,

8 LASTROP- Laboratório de Silvicultura Tropical da Escola Superior de Agricultura / NUPAUB Núcleo de Apoio à Pesquisa sobre Populações Humanas e Áreas Úmidas Brasileiras -Universidade de São Paulo. 
submetendo as diferentes formas de organização social a uma única e preestabelecida escala de análise.

O conceito de "população tradicional", além da importante conotação política, que a cada dia se torna imprescindível na luta pela permanência e legitimidade no uso dos recursos (Ferreira et al. , 2002), também assume o importante papel para a construção de um outro caminho. Isto se dá através da troca de experiências com o conhecimento formal desenvolvido nos meios técnicos e acadêmicos, guiados pelos preceitos do desenvolvimento sustentável.

\subsection{Os Atores principais - Os caiçaras do Saco doMamanguá}

\subsubsection{Populações tradicionais e a legitimidade do "Estar" vivendo em Unidades de Conservação...}

Para falar sobre as pessoas que vivem no Saco do Mamanguá, inicio com a discussão não muito bem resolvida sobre populações tradicionais. A construção deste termo tem início nos diferentes enfoques estudados pela antropologia, no que diz respeito à relação homem-natureza e nas diferentes escolas que daí derivaram. Ao tentar definir o conceito sobre populações tradicionais no contexto sócio-ambiental (Unidades de Conservação X populações humanas), vários autores manifestam a ambigüidade e a imprecisão deste conceito (Diegues \& Nogara, 1994; Cunha \& Almeida, 2000; Castro, 2000; Diegues \& Arruda, 2001; Adams, 2002).

Contudo, a discussão sobre o termo população tradicional transcende sua conceituação antropológica e assume toda uma amplitude política-ambiental, iniciada na década de 1980. É nesta década que se iniciam grandes conflitos originados pela institucionalização e implantação das áreas protegidas e é questionada a legitimidade dessas populações em "Estar" vivendo nessas áreas. Uma importante questão é colocada por Cunha \& Almeida (2000), motivo de grande polêmica entre (os assim definidos) preservacionistas e antropocentristas (Adams, 2002), os quais possuem diferentes visões sobre populações em Unidades de Conservação: as populações tradicionais podem ser descritas como conservacionistas culturais?

Aqueles que defendem a exclusão dessas populações de Unidades de Conservação, utilizam como argumentos: (i) que nem todas as sociedades tradicionais são conservacionistas e 
(ii) mesmo aquelas que ainda o são podem mudar à medida que jovens com espírito empresarial entrem em contato com o mercado e em conflitos com os costumes e com valores de reciprocidade, Cunha \& Almeida (2000, p.187).

Há um conjunto de idéias, defendido pelos antropocentristas e que é sustentado pelo baixo impacto das atividades de subsistência destas populações, como consequiência do etnoconhecimento sobre o meio em que vivem (Adams, 2002) define esses grupos como naturalmente conservacionistas e que resultou no que tem sido chamado de o "mito do bom selvagem ecológico" ou do "ecologicamente correto".

Diante desses impasses, Cunha \& Almeida, (2000) discutem populações tradicionais a partir de uma contextualização histórica das populações indígenas e dos seringueiros do Acre e sua importante mobilização política e ambiental. Convidam o leitor a analisar de forma "extensional" esta definição, na qual as categorias sociais são, ou tornam-se habitadas por povos que as convertem em bandeiras mobilizadoras, principalmente quanto à questão territorial, quando anteriormente eram carregadas de preconceitos, e o que há de mais importante, é que esta prática aponta para a formação de sujeitos políticos. E finalizam o raciocínio definindo que

"(...) a categoria de "populações tradicionais" é ocupada por estes sujeitos que estão dispostos a conferir-Ihe substância, isto é, que estão dispostos a construir um pacto: comprometer-se com uma série de práticas em troca de algum benefício, e sobretudo, de direitos territoriais. Nessa perspectiva, mesmo aquelas sociedades que são culturalmente conservacionistas, são não obstante, em certo sentido, neotradicionais ou neoconservacionistas" (Cunha \& Almeida, 2000, p. 192).

Diegues \& Nogara (1994) colocam como um dos critérios mais importante para definir populações tradicionais, além do modo de vida, o fato de reconhecer-se como pertencente àquele grupo social, o que remete a um dos temas centrais da antropologia: a questão da identidade. 
O surgimento de outras identidades socioculturais, como "caiçara"9, é fato mais recente, tanto nos meios acadêmicos quanto no auto-reconhecimento por essas populações como portadoras de uma cultura e um modo de vida diferenciados de outras populações (Diegues \& Nogara, 1994).

\title{
1.3.2 A construção e desconstrução de uma identidade - "Ser" Caiçara
}

\begin{abstract}
"O diferente é o outro, e o reconhecimento da diferença é a consciência da alteridade: a descoberta do sentimento que se arma dos símbolos da cultura para dizer que nem tudo é o que sou e nem todos são como eu sou"
\end{abstract}

Brandão, (1986, p. 7).

A origem do vocábulo "Caiçara" sinaliza para um dos componentes da origem tríade do povo brasileiro (índios, portugueses e os negros africanos) que significa o homem do litoral em tupi-guarani- caáiçara, (Sampaio citado por Adams, 2000).

Como já citado anteriormente é possível fazer um paralelo entre as culturas caipira e caiçara, já que estas surgiram da protocélula da nação brasileira (Adams, 2000). Os primeiros brasileiros são o resultado da miscigenação étnica-cultural entre índios, colonizadores portugueses e em menor grau, os negros africanos (Diegues, 1994, 2001; Ribeiro, 1995; Adams, 2000). Alguns autores, concordam ser a cultura caiçara uma subcultura, uma expressão regional da cultura caipira, não por constituir uma variação paralela desta, mas por fazer parte de inúmeros conjuntos (Silva; Pierson \& Teixeira; Noffs, citado por Adams, 2000).

"Caiçara é aqui do lugar, da roça que mora mais afastado, como caipira. Só que aqui a gente mora perto do mar. Então tem a roça e tem o mar".

9 Brandão (1986, p 145), cita como grupo étnico: “(...) um tipo organizacional peculiar culturalmente diferenciado de outros. Uma categoria de articulação de tipos de pessoas que, por estarem historicamente unidas por laços próprios de relações realizadas como famílias, redes de parentes, clãs, metades, aldeias e tribos, e por viverem e se reconhecerem vivendo em comum um mesmo modo peculiar de vida e representação da vida social, estabelecem para eles próprios e para os outros as fronteiras étnicas, os seus limites de etnia. Mergulhados em um sistema de relações regidas pela desigualdade, aprendem a pensar a diferença; aprendem a se pensar como diferentes". 
O que aproxima as duas culturas, apesar das diferenças regionais, e que pode ser traduzido como "modo de vida"10, são elementos socioculturais, presentes nos meios rústicos como, agricultura de coivara, mutirão, a fabricação de farinha de mandioca, a pesca de subsistência, a relação de compadrio, as novenas, as festas e folias (Mussolini, citado por Adams, 2000).

Para entender a formação da cultura caiçara é necessário inseri-la ao contexto dos ciclos econômicos e a ocupação do litoral brasileiro por essas economias de mercado. Devida a essa ocupação houve a formação de grandes e médios aglomerados populacionais. Porém, devido às condições da costa brasileira, surgiram também pequenos núcleos gravitacionais que por vezes, mantiveram-se estanques, com pouca comunicação em relação aos centros maiores. Nesses últimos anos, o que se observou foi o desenvolvimento de uma a agricultura exportadora, enquanto que nos pequenos núcleos desenvolveu-se a agricultura de subsistência, que muitas vezes era também responsável pelo abastecimento dos grandes engenhos, (Mussolini, 1980).

As populações caiçaras são descritas por Mussolini (1980) que as caracteriza pelo desenvolvimento de um tipo de vida fechada, quase que isolada das influências do mundo de fora e que resultou:

"(...) em um aproveitamento intensivo, quase exclusivo e mesmo abusivo dos recursos do meio criando-se por assim dizer, uma intimidade muito pronunciada entre homem e seu habitat. Conhece o homem muito bem as propriedades das plantas ao seu redor para remédios, para construções, para canoas, para jangada, bem como os fenômenos naturais presos à terra e ao mar que o norteia no sistema de vida anfíbia que leva, dividindo suas atividades entre a pesca e agricultura de pequeno vulto" (Mussolini, 1980, p. 226).

\footnotetext{
${ }^{10}$ Este modo de vida se estabelece em certas condições como: terra virgem, abundância de recursos naturais, fraca densidade demográfica, onde o mutirão assume importância crucial que permiti a obter a colaboração de outros núcleos em empreendimentos que exigem maior concentração de esforços, àquele que convocava o mutirão cabia prover alimentação e ao final da tarefa (derrubada da mata, "puxada de canoa", barreamento de uma casa ou consertos), realizava-se a festa com música e pinga, (Diegues \& Nogara, 1994; Ribeiro, 1995)
} 
A economia das comunidades caiçaras está baseada no que é chamado de "pluralismo econômico" que caracteriza a exploração dos recursos da terra e do mar (Maldonado, 1986). É um sistema econômico típico, caracterizado por complementaridade de atividades que garante a satisfação das necessidades da população, além de evitar a concentração da exploração de alguns poucos recursos naturais (Adams, 2000).

Através de uma análise processual histórica, existe uma diversidade de estratégias de subsistência adotadas pelos caiçaras, em determinados períodos de prosperidade, outras alternativas econômicas eram oferecidas e a agricultura de subsistência e a pesca eram abandonadas (Adams, 2002). Atualmente uma nova "safra" é integrada ao calendário anual de atividades, uma nova e importante atividade é agregada ao universo caiçara, dividindo o seu calendário em tempos e "safra" do turismo e sua "entre-safra". E é durante a entre-safra do turismo que as outras atividades, as chamadas de tradicionais, ganham novamente maior importância, e talvez, é quando a cultura caiçara é recriada ou rearticulada, (Rodrigues, 2000).

A cultura caiçara em geral sofreu um grande impacto nos últimos quarenta anos, com 0 avanço do turismo e da especulação imobiliária, e talvez seja a causa das mudanças mais avassaladoras em seu processo histórico. Diante das histórias semelhantes que ocorreram e que ainda ocorrem no litoral sul de São Paulo algumas questões são concebidas: "quais são as influências do turismo no modo de vida das populações caiçaras? Até que ponto o turismo se torna mera alegoria da identidade do caiçara"? (Rodrigues, 2000).

Até aqui discuti o que estruturalmente se reconhece por cultura caiçara, sua identificação como população tradicional, destacando as atividades tradicionalmente desenvolvidas e que foram até então valorizadas como harmoniosas, já que esta população habita os últimos refúgios preservados de Floresta Atlântica. Este fato, diante do debate ambientalista, fez com os antropocentristas se apoderassem de uma das facetas desta identidade ressaltando-a como poder de barganha no direito territorial em áreas protegidas. Contudo, em um artigo publicado pela Sociedade Brasileira de Etnobiologia e Etnoecologia Adams (2002), adverte para algumas sutilezas ao classificar determinados grupos como "populações tradicionais", e aqui no caso, refere-se aos caiçaras. E com base em Hill (1996) afirma que:

"A dicotomia criada entre povos "tradicionais" e "não-tradicionais" é paralisante, e dificilmente não se conseguirá, à posteriori, transformá-la em um entendimento global de suas 
identidades culturais". Propõem a "desconstrução" desta identidade, pois segundo sua análise, esta situação perpetua o estado de exclusão sócio-econômica e reforça a posição periférica e passiva dos caiçaras e sobreviventes de um passado remoto, dependentes incondicionais de suas atividades de subsistência" (Adams, 2002).

E mesmo frente a essa indefinição conceitual, a esses impasses, também acredito nas conseqüências e aspectos positivos de uma identidade assumida. Pessoas que ao se identificarem como caiçaras, obtêm como resultado certa mobilização e crescentes associações comunitárias. Assim, iniciam sua organização em torno do que é reconhecido pelo grupo, reclamam seus direitos territoriais diante da sociedade majoritária. Como o direito ao acesso aos recursos naturais e formas de comercializar seus produtos resultantes de uma forma diferenciada de exploração, na qual ainda é possível perceber seus traços culturais, como por exemplo, os que estão presentes na lavoura caiçara - descrita por Schmidt (1958) - e na culinária na pesca e em seus artesanatos.

O que é singular no Mamanguá...

Na região do Saco do Mamanguá, como descreveu Diegues \& Nogara em 1994, apesar da "safra do turismo" já fazer parte do cotidiano dessas pessoas, havia ainda a predominância do modo de vida tradicional caiçara (grifo nosso) e ainda há nos dias atuais. As famílias praticam a pesca de subsistência, plantam as roças de mandioca, confeccionam sua farinha e praticam a pequena caça. Utilizam em suas construções, benfeitorias e artesanatos, madeiras e produtos não-madeireiros retirados do mangue, caixetais e das florestas de encosta. Da floresta, os caiçaras exploram árvores de madeira propícia para a construção de canoas e outras embarcações (Diegues \& Nogara, 1994). A relativa importância que ainda hoje é dada a essas atividades, mesmo com o turismo cada vez mais presente na vida das pessoas que lá vivem, torna o Saco do Mamanguá singular. Fato este que se deve ao relativo isolamento geográfico dessa comunidade e do tipo de turismo que lá se desenvolveu com o predomínio de casas de veranistas. 


\subsection{A Roça e os quintais caiçaras caminhos paralelos rumo à alternativas frente à condição sócio-ambiental de populações em Unidades de Conservação}

\subsubsection{A roça caiçara}

Independente da influência e da pressão exercida pelo turismo nos últimos anos a comunidade do Saco do Mamanguá, como mencionado acima, ainda preserva fortes traços que definem sua população como tradicional, ou pelo menos quando a colocamos em relação aos parâmetros atuais das populações que habitam o litoral nessa região. Pode ainda ser definida como uma comunidade de pescadores-lavradores (Maldonado, 1986; Adams, 2002) e a agricultura praticada é ainda parte da fonte de subsistência para algumas famílias. Vou me ater ao uso da terra por esta população, muito embora é observada a drástica diminuição dos plantios nos dias atuais.

Ao traçar um paralelo entre dois sistemas de produção e suas práticas agroecológicas, as roças e os quintais, pode-se identificar um possível diálogo entre o "tradicional" e novas formas de subsistir diante do quadro político-ambiental, utilizando os recursos e os conhecimentos da terra, em que populações como a do Saco do Mamanguá se encontram. Ao estabelecer esse paralelo entre os dois sistemas tradicionais de cultivo, talvez seja possível encontrar formas e alternativas de manejo do espaço que venham ao encontro dos princípios da agrofloresta direcionada pela sucessão11, cuja proposta é a mudança de paradigmas dos sistemas de produção rural (Viana et al., 1997). Diante do contexto regional em questão (Floresta Atlântica), a agrofloresta apresenta-se como o tipo de manejo mais condizente com a vocação regional e também aquele que oferece um leque maior de produtos em diferentes épocas. No entanto, é preciso considerar a seguinte advertência feita por Adams (2000, p. 241)

“(...) novas técnicas agroecológicas devem ser cuidadosamente investigadas, uma vez que, as espécies e variedades utilizadas pelos caiçaras são resultado de fortes pressões

\footnotetext{
${ }^{11}$ A agrofloresta direcionada pela sucessão está baseada na teoria desenvolvida por Ernest Götsch, que considera a sucessão a instrumentalidade da vida em um contexto sintrópico, ambas em conjunto, como "vetores interrelacionados que giram a vida". Agrupa as espécies, classificando-as por sua função ecofisiológica, em um sistema que por sua vez, são constituídos por um ou mais ciclos de Pioneira (normalmente herbáceas), Secundárias I (com ciclo de vida curto), Secundárias II (com ciclo de vida médio), Secundárias III (com ciclo de vida longo) e as Transicionais (consórcio de espécies que domina o ciclo em sua fase adulta, pertencendo a ele, entre outros, os animais, (Silva, 2002).
} 
seletivas locais e de uma longa co-evolução com o homem (como a mandioca), e que se apresentam, portanto, mais adaptadas".

Uma das características desses sistemas (roças e quintais) é o grau de diversidade das plantas, geralmente na forma de policultivos e/ou padrões agroflorestais. A interação dos agricultores com seu ambiente, através de práticas agroecológicas, resulta em um conhecimento acumulado que surgiu no decorrer de séculos de evolução biológica e cultural (Altieri, 1994). E quando se fala especificamente dos quintais agroflorestais nota-se também, além da grande diversidade, os diferentes estratos, as interações entre as espécies, as funções ecológicas e zonas de manejo presentes neste sistema (Lok, 1998a). O que teoricamente proporciona subsídios para a discussão sobre práticas de manejo agroflorestal guiado pela sucessão de espécies, considerando todo o conhecimento e práticas já existentes em comunidades caiçaras.

Para entender esta relação entre o caiçara e seu ambiente, se faz necessário uma breve descrição da roça caiçara. A roça caiçara é resultado do conhecimento advindo desta relação e vários autores a descrevem em seus trabalhos com comunidades caiçaras, ou então, esta é um tema específico de suas pesquisas.

A organização do trabalho na roça é familiar, na qual encontra-se o melhor equilíbrio e por este motivo existem poucas famílias múltiplas ou extensas. Somente em situações adversas como morte de um dos cônjuges, admite-se agregar novos membros à família garantindo 0 equilíbrio vital do grupo doméstico (Adams, 2000).

Este tipo de agricultura itinerante de subsistência nas florestas ${ }^{12}$ foi inventada de forma independente em diferentes regiões tropicais e tem-se mostrado sustentável ao longo dos séculos. A interação com a floresta sempre ofereceu todos os produtos necessários ao dia-a-dia dessas populações. A cobertura vegetal apresenta-se em diferentes estágios de regeneração devido a utilização das encostas no passado por tempo continuado. Os agricultores itinerantes deixam trechos de florestas primárias intactos, de forma a manter espécies úteis, assim como

\footnotetext{
${ }^{12}$ Caracteriza-se como sistema de coivara e como o próprio nome indica, sua herança é indígena, chamada também de "roça de toco", agricultura itinerante de subsistência. Consiste na derrubada e queima da mata, seguida de plantio por três anos, e após esse período com o empobrecimento do solo e queda de produtividade, a área é abandonada por três a dez anos. A roça é considerada um bem comunal, embora os produtos das roças pertençam às famílias que as plantaram (Oliveira; Lima; Sampaio et al., 1994).
} 
habitat para os animais que utilizam para caça. Além disso, várias espécies da floresta secundária também são plantadas para atrair animais (Adams, 2000).

Sendo assim, a capoeira faz parte do ciclo agrícola, tanto pela incorporação de nutrientes ao solo, como pelo manejo das espécies por parte da população. Contudo, os autores advertem para o aspecto florístico e que a capoeira é extremamente pobre em espécies (menos de 20 espécies), porém, em termos de funcionamento ela é semelhante a um ecossistema maduro, como por exemplo às estruturas de ciclagem de nutrientes. $\mathrm{O}$ uso do fogo, quando controlado, constitui o principal agente fertilizador e de controle de acidez, já que as cinzas neutralizam o pH, a concentração de nutrientes é elevada e a toxicidade do alumínio é reduzido, (Oliveira; Lima; Sampaio; et al., 1994, p. 47; Felipim, 2000, et al., p.113).

No entanto, esse sistema para funcionar com perfeição pressupõe-se o respeito a certas regras relacionadas à freqüência de utilização do fogo, pois a maioria dos nutrientes está presente na biomassa e não no solo. $O$ desrespeito a essas regras pode ter como conseqüência a destruição dos mecanismos biológicos de reposição da vegetação nativa e propiciar a formação de uma comunidade formada por espécies resistentes ao fogo, como o sapé (Imperata brasilienses) e o alecrim (Baccharis dracunculifolia), sendo que nessas áreas nem a biomassa, nem a diversidade de espécies aumenta com o tempo (Lima et al. citado por Felipim et al., 2000, p. 113).

A roça é um sistema "primitivo" que prioriza a auto sustentabilidade e a reutilização dos recursos naturais, ao contrário do que é feito em nossa sociedade, a mesma onde nasce todo um discurso ecológico em contraposição. Mas, é ainda importante lembrar que esta sustentabilidade, tal como é descrita pelos autores, só é garantida pela baixa densidade demográfica presente em comunidades como por exemplo, as caiçaras (Oliveira; Lima; Sampaio; et al., 1994).

Portanto, as pesquisas realizadas em comunidades caiçaras descrevem práticas seculares e sustentáveis em regiões de baixa densidade demográfica. Mas, o que se observa por parte do Estado, ou dos órgãos responsáveis por políticas públicas é a adoção de um tipo de relação unilateral, que exclui o diálogo e a troca. Os autores atentam para o fato a ser considerado, que essas populações co-evoluíram com o meio ambiente e portanto podem contribuir com importantes subsídios para seu próprio futuro. E essa questão só poderá ser 
plenamente resolvida ao considerar essas populações como parte do ecossistema, (Oliveira; Lima; Sampaio et al, 1994, p. 51).

\subsubsection{Os quintais agroflorestais}

"Ao adentrar no Saco do Mamanguá a bordo da baleeira que desliza morosamente pelas calmas águas do "lugar que nos protege", o tempo que me é oferecido, é suficiente para os olhos se deliciarem com as imagens que vão sendo reveladas e que se compõem em meio ao verde exuberante da Floresta Atlântica. E então são reveladas as pequenas casas rodeadas não por menos verde, e se os olhos estiverem mesmo atentos, percebese que o que diferencia os lugares habitados de todo o resto, é a presença das muitas fruteiras. Por entre roupas penduradas nos varais ao vento e por entre redes de pesca e canoas à beira mar, estão as mangueiras, jambeiros, fruta-pão, abacateiros, araçás, grumixamas, laranjeiras, limoeiros, jaqueiras, muitas palmeiras de todos os tipos e flores de tantas cores, tudo, junto às casas, que em muitos casos, não com menos cores em suas janelas e portas. É ali então que a vida passa, é ali que a vida do homem do mar se confunde com a vida pungente da floresta, o espaço de transição entre o homem e a natureza: o quintal, relação esta expressa em sua última análise na cultura e na dieta caiçara" (Diário de Campo, 2001).

Os quintais agroflorestais são um tipo de sistema de produção entre os diferentes tipos de agroecossistemas. A interação entre os recursos naturais e seu manejo por parte das populações locais está baseado em suas necessidades e, em geral, se caracteriza por sua heterogeneidade e a utilização de tecnologias simples. Os quintais, como sistemas agroflorestais, através de sua complexidade, demonstram claramente as características desta interação, como: boas qualidades biofísicas, eficiente ciclagem de nutrientes, alta biodiversidade e grande potencial para a conservação da estrutura física e da fertilidade do solo (Lok \& Mendez, 1998).

Os quintais são áreas próximas às moradias e ainda mesmo que abandonadas, exibem uma grande variedade de espécies frutíferas, juntamente com plantios anuais. Os quintais caiçaras, por exemplo, garantem ingresso em diferentes épocas do ano de frutos e outros alimentos, como o café, a cana e o aipim (Adams, 2000).

O quintal agroflorestal é tão diverso em quantidade e variedade, como nenhum outro sistema agroflorestal. É complexo e variado em estruturas e associações e completo em sua funcionalidade (Lok, 1996). Os quintais são estudados no mundo todo e podem ser divididos em quintais agroflorestais de clima temperado e quintais agroflorestais tropicais. Estes apresentam diferenças significativas, quanto à diversidade e aos estratos neles presentes. São conhecidos por diferentes nomes em vários lugares e são sistemas amplamente utilizados especialmente por pequenos agricultores (Lima, 1994). São desenvolvidos estudos expressivos na Ásia, sobretudo nas ilhas da indonésia, em que os quintais são reconhecidamente diversos e apresentam 
diferentes estratos (Michon; Mary, 1990), na África (Okigbo, 1990), onde esse sistema possui um significado importante no aporte de gêneros alimentícios, e na América Latina, especialmente na América Central, com trabalhos desenvolvidos por centros de excelência, como o Centro Agronómico Tropical y Enseñanza-CATIE.

São muitos os tipos de quintais encontrados na América Latina, em função dos diferentes contextos sociais e culturais e aspectos geofísicos existentes nas zonas nas quais estão localizados (Lok, 1996). No Brasil existem trabalhos com quintais na Amazônia (Saragoussi et al.,1990; Lima, 1994; Leeuwen, 1995; 1999, Amoroso, 1981) e também trabalhos no interior de São Paulo com os quintais urbanos em um projeto desenvolvido na UNESP de Rio Claro, coordenado pela prof ${ }^{a}$. Dra Maria Christina de Mello Amoroso ${ }^{13}$. Esses estudos revelam as relações desses sistemas com a segurança alimentar e destacam também a função desse espaço como um campo de aclimatação e experimentação de espécies para posterior utilização em plantios maiores, sendo que um dos papéis fundamentais é a introdução de novas espécies, como no caso da Amazônia, e também no estabelecimento de uma agricultura adaptada à região. A pouca importância econômica e à baixa produtividade desses sistemas, é relatado por Leeuwen (1995), entretanto diferentes autores, entre estes Fernandes e Nariz, citado por Lok (1998b), enfatizam a importância dos quintais na complementação da dieta familiar, sendo esta sua principal função, juntamente com outros valores como: medicinal, estético e até mesmo cultural. Pois nesse espaço está expresso o conhecimento do agricultor/morador em relação ao local onde este se instala, assim como sua cultura.

De fato em muitos países os quintais agroflorestais assumem um papel significativo para a segurança alimentar das famílias de populações que praticam atividades de subsistência. Fornecem a estas um aporte extra e variado de alimentos e outros produtos, e por vezes podem também representar um pequeno ganho econômico direto ou indireto (Saragoussi et al., 1990). Os estudos relacionados aos quintais em sua maioria envolvem as questões sócio-econômicas das famílias e o aspecto cultural, são considerados como importantes dados complementares ao entendimento do sistema de produção quintal. Estes sistemas são extremamente importantes, porém complicados de serem entendidos, e requerem um enfoque multidisciplinar e integrado de

\footnotetext{
13 “Conhecimento Empírico de Sociedades Rurais ou de Origem Rural - Os quintais na área do município de Rio Claro, SP, que teve início em março de 1998.
} 
estudo, em combinação com uma visão de promoção/extensão aberta e tolerante (Lok; 1996). E através dessa abordagem multidisciplinar trata de explorar as diferentes e complexas relações construídas e existentes nesse espaço (Saragoussi et al., 1990).

Os pesquisadores do CATIE, no Proyecto de Huertos Caseros, caracterizam os quintais estudados por sua forma. Consideram que a forma inclui um conjunto de estruturas e que esta está fortemente relacionada à função.

"Dependendo de quem maneja o quintal, a função determinará sua forma e ambas determinam seus produtos, recursos e benefícios. A forma, por sua vez, pode gerar uma série de funções biológicas, ecológicas e geofísicas importantes para a estabilidade do sistema agroecológico do quintal e para seus habitantes, sendo que essas funções podem ou não ser conscientes por parte dos habitantes" (Lok, 1998a, p.11).

\subsubsection{A dieta caiçara e o uso das roças e quintais}

Ao considerar que os caiçaras têm na roça e nos quintais a base de sua subsistência, (juntamente com os pescados), a análise da relação entre o consumo dos produtos advindos desses sistemas e da situação sócio-econômica das famílias, permite perceber a complementaridade desses dois sistemas (roças e quintais), além da possibilidade de inferir sobre a importância destes, e da influência direta e mútua entre os recursos e a dieta familiar (Hanazaki, 2001). As mudanças no contexto sócio-ambiental e econômico podem afetar direta e indiretamente, de forma negativa ou (até mesmo) positiva as comunidades caiçaras. Portanto, a análise da dieta na comunidade do Saco do Mamanguá, parte da mesma premissa considerada por (Hanazaki, 2001, p. 98), a qual coloca que: "A relação entre usos de recursos e dieta pode refletir ajustes a situações de mudança. Não raro ocorrem situações de mudança no modo de vida e de subsistência de uma população local que são refletidas na dieta desta população."

Nas últimas décadas têm sido observadas mudanças nos hábitos alimentares, em vários países, revelando que os modelos de consumo e seus fatores determinantes são complexos. Assim, a adoção de uma abordagem multidisciplinar e comparativa, onde os vários aspectos da alimentação tais como (econômicos, sociais, culturais e nutricionais), possam ser avaliados, se faz ainda mais necessária, de modo a permitir a elucidação dos mecanismos responsáveis por 
essas mudanças e suas conseqüências, nos diferentes contextos sócio-econômicos. A alimentação pode ser analisada sob vários aspectos, independentes e complementares. Estes aspectos determinam o tipo de consumo alimentar de uma população. E quando se fala em alimentação não se pode negligenciar as relações do homem com seu meio (Oliveira \& ThébaudMony, 1997).

Ao reunir todas as perspectivas de análise do consumo alimentar, não se restringindo apenas ao processo de produção e de consumo, mas também considerando todas as etapas intermediárias, dentro do contexto social num sentido mais amplo, que visa a segurança alimentar, tem-se o conceito de "sistemas alimentares" em uma perspectiva histórica. Com isto, é obtida a compreensão do processo pelo qual os hábitos alimentares se constróem e evoluem (Oliveira \& Thébaud- Mony, 1997). Na pesquisa realizada no município de Mossâmedes, Brandão, (1981) também considera entre outros aspectos, as condições e relações sociais que permitem o acesso, o uso e as concretas relações do agricultor com a natureza e a definição dos valores dos alimentos que constitui assim, os hábitos alimentares, o que também foi observado por Murrieta (2001).

A análise aqui pretendida, busca através de seu tema central - os quintais, contribuir para a construção do possível caminho entre o conhecimento, as formas tradicionais de uso da terra, e o uso de novas técnicas, frente às novas condições sócio-ambientais. A partir do entendimento desses complexos sistemas de produção que apresentam diferentes funções e que refletem a relação direta estabelecida com quem os maneja (Lok, 1998a), é possível apontar funções ecológicas importantes, como também as relações e responsabilidades sociais no que tange, por exemplo, à segurança alimentar de uma família ou de uma comunidade e ainda a ocupação da terra e manejo dos recursos .

Partindo dessas reflexões estabeleci uma trajetória sintetizada em algumas perguntas norteadoras: (i) os fatores sócio-ambientais externos, citados acima, implicam em que mudanças na comunidade do Saco do Mamanguá?; (ii); os quintais podem sintetizar ou espelhar essas mudanças? e (iii), como essas mudanças são refletidas nos hábitos alimentares dessa comunidade? 


\subsection{Objetivo da Pesquisa}

$\mathrm{Na}$ tentativa de responder a essas perguntas estabeleci como objetivo da pesquisa realizar a caracterização dos quintais de alguns grupos familiares do Saco do Mamanguá, do ponto de vista social, econômico e etnoecológico, para gerar informações capazes de (i) dar visibilidade à contribuição significativa dos mesmos para a segurança alimentar das famílias e para (ii) incentivar, futuramente, a formulação e adoção de novas práticas agroflorestais na comunidade, em sintonia com os princípios do desenvolvimento sustentável. 


\subsection{O LocAl de Estudo e o ReCORTE MEtodológico}

\subsection{A Escolha do lugar, tudo tem um começo}

"VOU VOLTAR, SEI QUE AINDA VOU VOLTAR..."

Até chegar ao local de estudo, um pouco da minha trajetória...

Logo após o término do meu bacharelado em Ciências Biológicas na Universidade Estadual de Londrina, onde realizei um trabalho com pequenos agricultores sobre o potencial de implantação de sistemas agroflorestais para a recuperação da vegetação ao longo do "Ribeirão dos Apertados", comecei a participar das atividades desenvolvidas no Laboratório de Silvicultura Tropical (LASTROP)- do Departamento de Ciências Florestais da ESALQ/USP. Minhas primeiras atividades estiveram ligadas ao projeto financiado pela Fundação Ford em Iguape- SP, onde entre outras coisas, fui a responsável pelo curso destinado aos professores da rede pública de ensino fundamental e médio do município, cujo tema foi o seguinte: "O Caixetal, A Escola e o Ambiente Sustentável". Neste mesmo período, o LASTROP iniciava o desenvolvimento de atividades na comunidade do Saco do Mamanguá na APA do Cairuçu, junto com minha chegada. Portanto, a escolha do local de estudo foi determinada diretamente pelo envolvimento e desenvolvimento dos trabalhos pelo LASTROP nesta comunidade, das quais participei inicialmente como monitora nas práticas de campo, anteriormente e durante o mestrado, na disciplina do curso de graduação de Engenharia Florestal: "Manejo Florestal por Populações Tradicionais", ministrada em 1998 a 2000. Participei também da disciplina de pós- graduação do programa de Recursos Florestais ministrada em 2001, no Saco do Mamanguá e também do Programa de Extensão Universitária sobre o "Manejo Comunitário das Florestas de Caixeta", destinado aos artesãos desde de 1999. 
Maio de 1998 -

A disciplina chegava ao fim, depois de uma semana na qual fui monitora do grupo de quintais, sem saber exatamente o que aquilo tudo poderia significar, deixamos o Saco do Mamanguá, e ao olhar para trás diante da imagem naturalmente imponente, muitas reflexões sobre o trabalho com as pessoas e a intensidade desta experiência, quantas descobertas... E em meio aos deslumbramentos e as incertezas, a música falava de um futuro próximo: "Vou voltar, sei que ainda vou voltar..."E assim foi o início.

O próximo contato com a comunidade se deu por conta do curso que o Laboratório de Silvicultura Tropical- LASTROP, realizou para discutir o manejo da árvore de caixeta (Tabebuia cassinoides), madeira utilizada para a confecção do artesanato por aproximadamente 50 famílias no Saco do Mamanguá. Minha função naquele momento foi mobilizar os artesãos convidando-os a participar da discussão sobre seu "manejo". A palavra manejo era nova para a maioria das pessoas e este conceito foi discutido diretamente no campo durante o curso ${ }^{14}$, através de métodos participativos e práticas silviculturais adaptadas aos costumes e necessidades dos artesãos. Por mais três anos a disciplina de Manejo Florestal por Populações Tradicionais foi ministrada no Mamanguá, o que possibilitou o estreitamento dos laços da equipe do laboratório com a comunidade, o "ajuntamento" de fragmentos de conhecimentos das pessoas que ali moravam, o envolvimento com a situação sócio-ambiental do lugar, que por fim resultou nesta dissertação de mestrado

A monitoria durante as disciplinas de campo foi muito importante no processo que resultou no tema proposto e no projeto de mestrado, assim como o inevitável envolvimento afetivo com as pessoas e seu lugar.

\footnotetext{
${ }^{14}$ O curso destinado aos artesãos caixeteiros, ocorreu em novembro de 1999, em seguida o LASTROP deu continuidade às atividades com a comunidade, como: (i) viabilização da legalização do manejo da caixeta, junto ao Instituto Estadual de Florestas -IEF do Rio de Janeiro (ii) levantamentos de informações sobre os caixetais presentes no Saco do Mamanguá (localização, inventários, estoque/demanda do recurso, além dos aspectos sócio- econômicos sobre os artesãos) e (iii) acompanhamento de pequenos grupos (mutirões) no manejo da caixeta nos anos seguintes. Desta forma obteve-se uma visão ampla de toda a cadeia de produção da Tabebuia cassinoides, desde a matéria- prima até o lojista/consumidor.
} 


\subsection{Cenário que se apresenta}

"(...) esses pequenos núcleos que se formaram graças à certas condições particulares da linha costeira, aproveitando-se das menores condições que pudessem ser favoráveis ao homem, passaram em geral a gravitar ao redor dos centros maiores tornando-se seus satélites, enviando-lhes sua parca produção como- farinha de mandioca, peixe, algum café- quando não se converteram em compartimentos estanques, com pouca comunicação para o interior e não raro também entre si, em virtude dos obstáculos à comunicação por terra" (Mussolini, 1980, p. 221 )

O pequeno trecho acima nos remete a uma parte do provável cenário que se compôs com a cultura caiçara e se desenvolveu em meio aos acidentes geográficos na Floresta Atlântica, e que atualmente ainda permanece, graças a sua alta resiliência bem verdade, em sua exuberância de formas, cores e cheiros. É no sudeste do Brasil onde ainda estão situados os melhores e mais preservados remanescentes de Floresta Atlântica, localizados na Serra do Mar, devido à topografia de difícil acesso para as práticas da agricultura convencional (Leitão Filho, 1993).

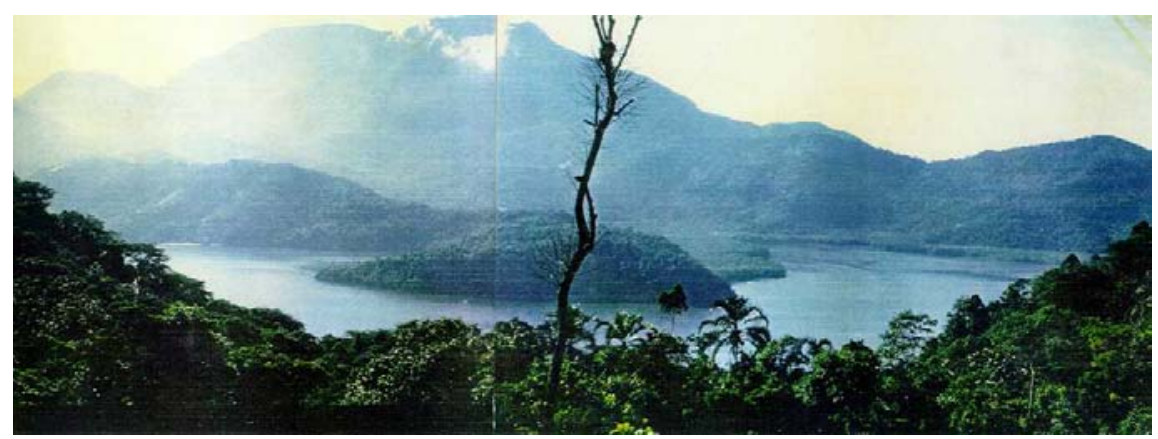

Figura 1 - Vista do Fundo do Saco do Mamanguá, foto de Paulo Nogara

No sul do litoral fluminense encontra-se o Saco do Mamanguá (Figura 1). O local constitui-se em uma área litorânea do tipo estuarina, e trata-se de uma reentrância do mar com aproximadamente $9 \mathrm{Km}$ de comprimento por 1,5 Km de largura. 
O Saco do Mamanguá pode ser ainda dividido em Margem Continental, Fundo do Saco e Margem Peninsular, cujo acesso se dá apenas por barco (Diegues \& Nogara, 1994). Faz parte da Área de Proteção Ambiental - APA- Cairuçu, que se localiza no extremo sul do município de Paraty-RJ, entre os paralelos de $23^{\circ} 10^{\prime}$ e $23^{\circ} 23^{\prime}$ lat. S e os meridianos de $44^{\circ} 30^{\prime}$ e $44^{\circ} 51^{\prime}$ 'lon. W. Sobrepondo-se a APA do Cairuçu, tem-se ainda a Reserva Ecológica da Juatinga, outro tipo de Unidade de Conservação, da qual a margem peninsular do Mamanguá também faz parte.

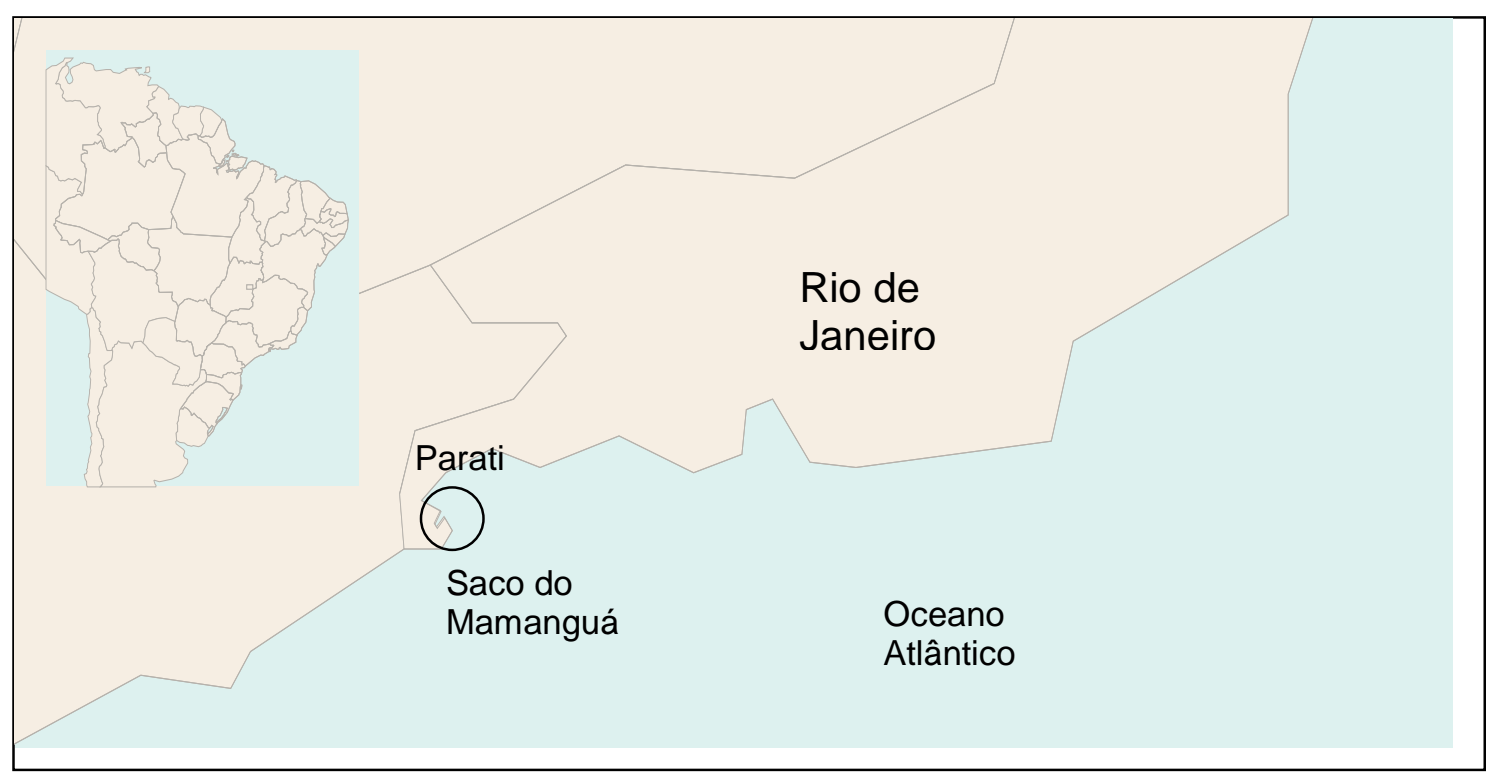

Figura 2 - Localização do Saco do Mamanguá

Está situado na vertente oceânica da Serra do Mar. Possui relevo bastante acidentado, variando desde ondulado, montanhoso e escarpado, com altitudes que vão do nível do mar até 1.070 m, no Pico do Cairuçu (Marques, 1997). O tipo de clima é supeúmido, com pouco ou nenhum déficit de água, mesotérmico com calor bem distribuído o ano todo. Os solos que ocorrem na parte movimentada do relevo, são em geral, de elevada acidez e com indicativos de baixa fertilidade. Em áreas planas, em pequenas várzeas, os solos são também ácidos, hidromórficos, argilosos e muito argilosos sendo influenciados pelo elevado lençol freático durante o ano todo ou por um longo período (Marques, 1997).

Ainda segundo a mesma autora, a cobertura vegetal predominante é a Floresta Ombrófila Densa, áreas onde já ocorreu exploração seletiva; conversão em áreas cultivadas e/ou 
pastagens onde 0 desmatamento foi intenso. As formações vegetais com influência fluvial (caixetais), fluvio - marinha (manguezais) e marinha (praias e restingas), ocorrem em áreas relativamente pequenas. As áreas planas são reduzidas, restritas a estreitas faixas de várzeas e manguezais.

Em 1994, residiam 119 famílias com 527 moradores e 21 propriedades particulares de turistas, divididos em vários povoados (Praia da Romana, Cruzeiro, Baixio, Regato, Curupira, Pontal, Praia Grande, Praia da Paca, Praia do Engenho e outros), espalhados pela comunidade (Diegues \& Nogara, 1994) ${ }^{15}$. Esse estudo se desenvolveu em 19 grupos familiares, distribuídos em diferentes povoados, que foram selecionados segundo alguns critérios que serão apresentados adiante.

${ }^{15}$ Procurei durante a pesquisa atualizar os dados censitários sobre a população, contudo não obtive respostas ao procurar essas informações na Prefeitura de Paraty, através da Secretaria de Ação Social que também não possuía esses dados atualizados. 


\title{
2.3 O Recorte metodológico
}

\begin{abstract}
"Se o experimento é repetível, a experiência é irrepetível, sempre há algo como a primeira vez. Se o experimento é preditível e previsivel, a experiência tem sempre uma dimensão de incerteza que não pode ser reduzida. Além disso, posto que não se pode antecipar o resultado, a experiêncianão é o caminho até um objetivo previsto, até uma meta que se conhece de antemão, mas é uma abertura para o desconhecido para que 0 que não se pode antecipar nem "pré-ver" nem "pré-dizer"

(Larrosa; 2001) ${ }^{16}$.
\end{abstract}

\subsubsection{Os procedimentos metodológicos e suas bases teóricas}

Minha estratégia de intervenção e o desenvolvimento do trabalho foram baseados na associação de diferentes métodos e técnicas, inicialmente norteados pelos princípios da pesquisa-participante, que buscou durante o processo da pesquisa de campo a participação dos sujeitos como atores sociais. Nessa perspectiva, o sujeito social é considerado parte fundamental do trabalho com a intenção de despertá-lo para problematização e ações a partir dos fatos observados conjuntamente (Freire, 1984; Thiollent, 1984; Brandão 1984).

É preciso no entanto, assinalar e fazer a ressalva quanto as limitações do processo participativo durante o trabalho de pesquisa, por se tratar de uma dissertação, em que existem prazos a serem cumpridos, e o projeto dependia da aprovação e financiamento. As atividades de pesquisa foram delineadas por mim, inclusive na proposição do tema e sua problematização (que mesmo sendo discutido com todas as famílias com as quais interagi, foram pré-concebidos).

Diante dessa ressalva e na tentativa de definir e enquadrar os métodos aqui aplicados dentro de uma categoria de pesquisa diferenciada da convencional, acredito ter desenvolvido um trabalho dentro da linha do que é colocado como pesquisa-intervenção educacional e em poucas palavras apresento a seguir a definição apresentada por Oliveira, (2002) a qual também embasou as ações de sua pesquisa de mestrado:

A pesquisa intervenção educacional pode ser uma intervenção para a solução de um problema específico e/ou uma intervenção educacional. (...) A pesquisa intervenção dialoga com a pesquisa-ação e a pesquisa-participante e pode envolver o público ao qual se destina como

\footnotetext{
${ }^{16}$ Conferência proferida no I Seminário Internacional de Educação de Campinas, traduzida e publicada, em julho de 2001, por Leituras SME; Textos - subsídios ao trabalho pedagógico das unidades da Rede Municipal de Educação de Campinas/FUMEC.
} 
sujeito do pesquisar, mas pode não envolvê-lo de forma ativa, portanto, pode não ser a ação do participante, mas só do agente externo" (Oliveira 2002, p.49).

Nos processos educativos faz parte prever a discussão no andamento do trabalho sobre a complexidade da situação na qual a comunidade está inserida. E durante esse processo devese propiciar o levantamento de problemas, estratégias e o potencial para resolvê-los por parte dos interessados. A educação socialmente produtiva supõe fazer da educação o elemento integrador e aglutinador de todo o processo que garanta a homens, mulheres e grupos produtivos chegar à condição de atores reais e conscientes dos processos sociais (Guitiérrez, 1993). E é nesta prática que pesquisador e o sujeito de pesquisa encontram maior interação, como é colocado por Freire a seguir:

"(...) quanto mais, em uma tal forma de conceber e praticar a pesquisa, os grupos populares vão aprofundando, como sujeitos, o ato de conhecimento de si em suas relações com a sua realidade, tanto mais vão podendo superar ou vão superando o conhecimento anterior em seus aspectos mais ingênuos. Deste modo, fazendo pesquisa, educação e estou me educando com os grupos populares. Voltando à área para pôr em prática os resultados da pesquisa não estou somente educando ou sendo educado: estou pesquisando outra vez. No sentido aqui descrito pesquisar e educar se identificam em um permanente e dinâmico movimento." (Freire, 1984, p.36).

Os procedimentos de pesquisa adotados durante o trabalho de campo se deram através de observações diretas e registros em diário de campo durante o convívio com as famílias e que complementaram as entrevistas semi-estruturadas, foram realizados registros da história oral, pois é através das falas dos informantes que se pode constatar valores, expectativas, ideais de vida, ponderações, frustrações e sofrimentos (Brandão, 1981) levantamentos sócio-econômico das famílias participantes da pesquisa, além de várias situações informais que também constituíram importantes fontes e trocas de informações. Essas técnicas são características de um instrumental típico das Ciências Sociais e associadas a essas estão as técnicas utilizadas em Ciências Naturais (Marques; 1995), como levantamento florístico e coleta botânica, confecção de perfis verticais e horizontais dos quintais que juntas compõem o arcabouço metodológico utilizado para a caracterização e compreensão etnoecológica dos quintais. 
Entender qual a percepção do agricultor em relação ao seu entorno natural, como também o econômico e o social passaram a ser um elemento essencial da análise. Se a lógica do produtor não for compreendida, nunca será possível chegar a uma proposta aceitável por ele, mesmo que o agroecossistema seja compreendido (Weid; 1995).

Assim, a etnobiologia, um campo relativamente novo da ciência, também apresenta seu método e sua teoria em construção, na busca de entender os processos de interação das populações humanas com os recursos naturais, com especial atenção à percepção, conhecimento e usos (incluindo o manejo dos recursos).

"A etnobiologia tenta inferir de que modo os povos classificam seu ambiente físico e cultural. Ao tratar de diferentes comunidades em ambientes distintos, a etnobiologia é particularista e relativista, no sentido de focalizar uma dada comunidade e seu ambiente, procurando compreender os processos de conhecimento e do manejo dos recursos naturais" (Begossi et al., 2002).

E é com esta abordagem que são realizados os estudos das interações do homem com a natureza através do conhecimento e das conceituações desenvolvidas por determinada comunidade a respeito da biologia, dentro do seu sistema de crenças e mitos englobando ainda várias categorias de pesquisa como por exemplo, a etnobotânica (Posey, citado por Hanazaki et al., 2000).

Desta forma procurei tecer um caminho próprio, associando diferentes métodos seguindo os referencias acima citados, no qual seria possível caracterizar os quintais de forma abrangente. Cabe então citar a colocação feita por Becker ao se referir aos possíveis caminhos traçados pelo pesquisador: $O$ pesquisador deve se sentir livre para tecer os métodos capazes de resolver os problemas da pesquisa que está realizando (...) estas decisões não podem ignorar princípios metodológicos gerais que são encontrados em livros e artigos sobre metodologia que oferecem caminhos, mas sim adaptá-los à uma situação específica ao considerar suas variações e peculiaridades (Becker; 1999).

Para realizar esse estudo, considerei os quintais como resultado da interação íntima entre as pessoas que neles residem e os fatores externos que podem influenciar e serem refletidos no dia-a-dia, neste espaço e por fim nos hábitos alimentares dessas pessoas. Tentei chegar aos caminhos que me conduziriam além da caracterização dos quintais, e que durante 
todo o processo, entre visitas e cafés, poderiam também conduzir para a reflexão conjunta da situação atual da comunidade frente aos problemas comuns entre os grupos familiares que participaram direta e indiretamente dessa pesquisa.

Em uma primeira etapa realizei um diagnóstico, aprofundei meu envolvimento no contexto social da comunidade e com os integrantes dos grupos familiares, visitando as famílias com as quais já mantinha contato anterior à pesquisa a procura de maiores informações acerca de outras famílias em potencial para o desenvolvimento do trabalho, neste primeiro momento também foi entregue para a AMAM e para os professores, um texto informativo sobre o trabalho que segue no Anexo A. Em uma segunda etapa, foram discutidos os temas que estavam em pauta (os acontecimentos recentes que envolviam pessoas da comunidade e os diversos "causos" que iam sendo relatados a cada conversa) com as famílias, com lideranças. Procurei esclarecer o propósito da pesquisa, os objetivos, além das explicações sobre as técnicas que seriam aplicadas, sobre a coleta de informações e de material botânico que se realizou concomitantemente, o porquê dessas coletas e como seriam utilizadas. Realizei o levantamento de depoimentos durante a pesquisa que, junto às informações secundárias obtidas em bibliografias e literatura sobre a cultura caiçara, sobre a região do litoral norte de São Paulo e sul fluminense, e do próprio Saco do Mamanguá, ofereceram elementos para o entendimento do processo histórico social e ambiental e que resultou em sua atual configuração.

\subsubsection{A escolha dos quintais estudados na comunidade do Saco do Mamanguá}

A escolha dos quintais se deu a partir de alguns critérios adotados com base na vivência com algumas famílias da comunidade e das observações realizadas no período anterior ao projeto de pesquisa, através das atividades desenvolvidas no Saco do Mamanguá e que foram importantes. Selecionei quintais em sete povoados que estão espalhados entre a APA do Cairuçu e a REJ, e são eles: Regate, Curupira, Pontal, Praia Grande, passando pela Praia da Bica que se encontram na área continental do Saco do Mamanguá e estão localizados na APA do Cairuçu, totalizando doze quintais, já no lado da Reserva Ecológica da Juatinga os povoados escolhidos para o estudo dos quintais foram: Ponta da Romana, Cruzeiro, Baixio, totalizando sete quintais. Em cada povoado foram estudados de dois a três quintais, a pesquisa iniciou-se em doze 
quintais e em seguida foram sendo acrescidos os outros, e que chegou a um total de dezenove quintais estudados. "Pessoas-chaves" foram indicadas e essas se encaixavam nos critérios considerados e a pesquisa foi iniciada nos quintais dessas pessoas. As indicações foram feitas tanto pelo presidente da Associação dos Moradores e Amigos do Mamanguá -AMAM, como por um biólogo atuante no local de estudo há aproximadamente dez anos. A partir daí segui também as indicações de pessoas já envolvidas na pesquisa, que geralmente apontaram pessoas mais velhas, parentes e vizinhos.

Para escolher os quintais nos povoados citados acima, parti do pressuposto que a localização dos quintais dentro da comunidade do Saco do Mamanguá poderia determinar relações diferenciadas de seus moradores com o turismo local, as quais subdividi em diretas e indiretas. Esse pressuposto foi considerado ao observar que as casas de veranistas se concentram mais em alguns povoados localizados na saída do Saco do Mamanguá para o mar aberto. No fundo, onde se encontra o mangue, a água é mais turva devido à baixa profundidade e a concentração de matéria orgânica, neste local também há maior incidência de mosquitos ("pórvinha e maruí", como são chamados pelos moradores locais), em especial nas épocas de lua cheia e nova. Com isso o local ainda é pouco procurado por esse tipo de turismo mais desenvolvido no Saco do Mamanguá. E assim, as relações (diretas e/ou indiretas) das famílias caiçaras com os veranistas poderiam revelar as possíveis diferenças quanto ao uso da terra por estas, a percepção do lugar por seus moradores, as principais atividades desenvolvidas pelas famílias e as contribuições dos quintais e dos recursos locais na dieta familiar. Os demais critérios considerados foram: (i) quintais de famílias caiçaras de diferentes tamanhos e estruturas; (não foram considerados os quintais dos veranistas, muito embora há referências a estes, como resultado das entrevistas e conversas informais com os moradores); (II) a receptividade dos integrantes das famílias em relação à pesquisa ${ }^{17} \mathrm{e}$ (iii) inclusão de quintais de pessoas com idade acima de cinqüenta anos.

A receptividade das pessoas em relação à pesquisa foi considerada como um fator importante, já que além de propor a maior interação possível com os moradores e a tentativa de promover discussões acerca do tema, esse estudo se caracteriza como um trabalho, diria quase 
invasivo, pois foi preciso estar na casa com seus moradores, falar sobre os hábitos, sobre a alimentação, interromper muitas vezes os afazeres diários dessas pessoas, para que me acompanhassem nas visitas aos seus quintais e apesar da surpresa das minhas visitas, que era quase inevitável, sempre estavam disponíveis para conversas. A inclusão de pessoas com idade acima de cinqüenta anos, responsáveis pelos núcleos familiares, teve como intuito obter informações sobre a história mais recente e identificar as possíveis mudanças ocorridas na história do lugar, em relação ao uso da terra, as relações de trabalho, aos hábitos alimentares e quais foram os agentes promotores dessas mudanças. Considerei apenas os quintais caiçaras e famílias que ainda os possuem, para caracterizá-los e verificar a relação destes com a dieta familiar.

\begin{tabular}{|l|c|c|l|}
\hline \multirow{2}{*}{ Quintais } & \multicolumn{3}{|c|}{ Critérios Considerados para Escolha dos Quintais } \\
\cline { 2 - 4 } & Idosos & $\begin{array}{c}\text { Presença de casa } \\
\text { de veranistas }\end{array}$ & \multicolumn{1}{|c|}{ Indicados } \\
\hline R1 & & & Moradores \\
\hline R2 & $\mathbf{X}$ & & Contato anterior \\
\hline C1 & $\mathbf{X}$ & $\mathbf{X}$ & Contato anterior \\
\hline C2 & & & Moradores \\
\hline C3 & & $\mathbf{X}$ & Contato anterior \\
\hline PP1 & $\mathbf{X}$ & $\mathbf{X}$ & AMAM \\
\hline PP2 & $\mathbf{X}$ & $\mathbf{X}$ & Moradores \\
\hline PP3 & $\mathbf{X}$ & $\mathbf{X}$ & Contato anterior \\
\hline PB & $\mathbf{X}$ & $\mathbf{X}$ & Moradores \\
\hline PG1 & & $\mathbf{X}$ & AMAM \\
\hline PG2 & $\mathbf{X}$ & $\mathbf{X}$ & Contato - pesquisa \\
\hline PG3 & &
\end{tabular}

Quadro 1 - Critérios adotados para a escolha dos quintais estudados

Obs: As siglas apresentadas acima correspondem aos grupos familiares estudados, pertencentes aos respectivos povoados do Saco do Mamanguá: $-\mathbf{R}=$ Regate; $\mathbf{C}=$ Curupira; $\mathbf{P P}=$ Praia do Pontal; $\mathbf{P B}=$ Praia da Bica; PG= Praia Grande; PR= Ponta da Romana; $\mathbf{C Z}=$ Cruzeiro; $\mathbf{B A}=$ Baixio

${ }^{17}$ A receptividade dos agricultores é uma característica, entre outras, considerada pelos autores que realizaram a caracterização de quintais na Nicarágua, (Víquez et al, 1994, p. 6). 


\begin{tabular}{|l|c|c|l|}
\hline \multirow{2}{*}{ Quintais } & \multicolumn{3}{|c|}{ Critérios Considerados para Escolha dos Quintais } \\
\cline { 2 - 4 } & Idosos & $\begin{array}{c}\text { Presença de casa } \\
\text { de veranistas }\end{array}$ & \multicolumn{1}{|c|}{ Indicados } \\
\hline PR2 & & $X$ & Contato - pesquisa \\
\hline CZ1 & & & AMAM \\
\hline CZ2 & $X$ & & AMAM \\
\hline BA1 & & & Contato anterior \\
\hline BA2 & & & Contato anterior \\
\hline BA3 & & $X$ & AMAM \\
\hline
\end{tabular}

Quadro 1 - Critérios adotados para a escolha dos quintais estudados

Obs: As siglas apresentadas acima correspondem aos grupos familiares estudados, pertencentes aos respectivos povoados do Saco do Mamanguá: $-\mathbf{R}=$ Regate; $\mathbf{C}=$ Curupira; $P P=P r a i a$ do Pontal; $P B=$ Praia da Bica; $P$ G = Praia Grande; $P R=$ Ponta da Romana; $\mathbf{C Z =}$ Cruzeiro; $\mathbf{B A}=$ Baixio

\subsubsection{As entrevistas semi-estrutradas durante as boas conversas de café}

Em meio às conversas informais, as conversas de café, as entrevistas semi-estrutradas foram realizadas. Elaborei um roteiro (Anexo B), com base em Lima (1994) com perguntas que nortearam o levantamento sócio-ambiental.

A entrevista semi-estrutrada ${ }^{18}$ por sua natureza interativa é uma entre as diversas técnicas aplicadas nas pesquisas sociais, que quando aliadas às demais técnicas, como observação participante, os relatos de histórias de vida, permite tratar de temas complexos (como por exemplo, os quintais e seu enfoque multidisciplinar). Muitas vezes a sensação de parecer um "extraterrestre" se fez presente. Era preciso encontrar elementos que aproximassem mundos diferentes, o meu e o das pessoas entrevistadas, então como dar início a uma entrevista?

Em meio às conversas de café a entrevista acontecia, ao falar de coisas da vida e entre as histórias que estavam em pauta, surgiam os elementos, as informações que eram garimpadas e mais tarde passadas para o diário. No desenrolar das conversas incluía algumas perguntas

\footnotetext{
${ }^{18}$ Calvente em seu trabalho com uma comunidade caiçara, também se utiliza dessa técnica e observa suas vantagens em estudos com populações, ao citar Triviños declara que a entrevista estruturada privilegia o objeto, sendo usada pelo modelo positivista, enquanto a entrevista não-diretiva privilegia o sujeito. A
} 
sobre o quintal, sobres as plantas e a família, e assim ia entendendo aos poucos as dimensões do tema quintal e as relações mantidas entre os diferentes elementos, tanto sociais como ambientais.

Durante essas visitas tive a boa oportunidade de tomar cafezinhos que em algumas casas o café havia sido colhido no próprio terreiro, seco na "pedra do café", (pedras grandes que ocorrem por toda a comunidade e em alguns terreiros), e depois era torrado e moído em pilão de jaca, também degustei os maravilhosos bolinhos de fruta-pão e de aipim cozido, produzidos nos quintais, com um gosto especial para quem vem da cidade grande. Gostos e cheiros também constróem histórias.

As entrevistas foram realizadas em dezenove famílias, com o total de vinte e duas mulheres e de dezenove homens entrevistados (as), entre jovens, adultos e idosos, abaixo apresento a seguir um quadro que demonstra o público com quem interagi mais ativamente.

\begin{tabular}{|l|l|l|}
\hline \multirow{2}{*}{ Faixa Etária } & \multicolumn{2}{|l|}{ Número de entrevistados } \\
\cline { 2 - 3 } & Homens & Mulheres \\
\hline Jovens & 01 & 02 \\
\hline Adultos & 10 & 11 \\
\hline Idosos & 08 & 09 \\
\hline Subtotal & 19 & 22 \\
\hline Total & 41 entrevistados \\
\hline
\end{tabular}

Quadro 2 - Relação dos entrevistados divido por faixa etária e gênero

E dessa forma o conjunto de informações sobre os integrantes das famílias foi se constituindo, dados como: nível de instrução, idade e principais atividades desenvolvidas por eles. Outras questões, as quais estavam mais relacionadas ao espaço físico dos quintais foram complementadas através de caminhadas junto aos seus moradores e aí verifiquei: (i) as plantas presentes nos quintais, aquelas que eram indicadas pelos informantes procurava saber o uso destas; (ii) benfeitorias, (iii) existência e tipos de criação, (iv) horta (v) idade e manejo do quintal; 
e (vi) lixo. Estas informações não foram obtidas em apenas uma visita e sim no decorrer de todo o trabalho de campo.

Além das entrevistas com os integrantes dos grupos familiares estudados, outras tantas conversas informais aconteceram, com as lideranças, com os pastores das igrejas evangélicas da comunidade, com os professores das escolas, merendeiras e demais moradores que complementaram as informações obtidas através das entrevistas como também possibilitou trocas de experiências e discussões mais intensas com parte da comunidade. A checagem das informações obtidas foi realizada com a apresentação destas em cada família e com as pessoas da comunidade, com os professores das escolas do Mamanguá e com integrantes da Associação de Moradores e Amigo do Mamanguá- AMAM. E se deu durante todo o trabalho de campo, levei também os relatórios preliminares apresentados à Fundação de Amparo à Pesquisa do Estado de São Paulo-FAPESP, os quais eram lidos por mim, discutidos e ilustrados com as figuras, tabelas, e fotos presentes nos textos.

Esses momentos proporcionaram ricas discussões não somente sobre o tema principal, os quintais, mas também proporcionou espaço para reflexão da própria condição em que a comunidade se encontrava, inclusive sobre a participação das pessoas como "atores" que estão construindo sua própria história e têm o direito e também o dever de opinar e entender-se como parte e não à parte.

É preciso fazer um adendo especial: durante a pesquisa tive a boa companhia de um jovem morador de vinte anos, que foi uma das pessoas com quem estabeleci uma interação de troca mais efetiva durante todo o trabalho, pois ele me acompanhou e me auxiliou inicialmente na coleta e prensa do material botânico e esteve presente em várias atividades de campo, inclusive em outros quintais. Nos dois últimos trabalhos de campo participou também das medições das áreas e da confecção dos perfis verticais e plantas baixas (croquis). Estas atividades propiciaram momentos ricos e trocas que se concretizaram durante as coletas, nos caminhos, onde conversávamos sobre botânica, política, as funções das árvores e grupos ecológicos, a água, participação nas decisões, papel social, responsabilidades, angústias, sonhos. Falava-se também sobre o turismo e as pessoas, suas histórias e sobre os conflitos internos na comunidade. Estas interações resultaram ainda na elaboração espontânea de um caderno de campo escrito por ele,

hipóteses, que surgem com as respostas dos informantes (Calvente, 192, p.13). 
no qual ele abordou assuntos referentes à botânica e ecologia, especialmente e algumas reflexões/curiosidades sobre o papel do "pesquisador" e da pesquisa científica. Outro reflexo dessa boa interação foi à entrada dele para a AMAM.

\subsubsection{Levantamento etnobotânico}

Para realizar o levantamento etnobotânico, optei por uma abordagem qualitativa e quantitativa, já que este tipo de levantamento aborda diversos dados referentes a uma série de informações sobre como as pessoas locais interagem com seu meio natural (Martin, 1995).

O levantamento etnobotânico procurou responder questões quanto à diversidade presente nos quintais, conhecimento e uso das plantas e quem as maneja, informações sobre a fenologia, o hábito, e também identificar o estrato predominante, além do histórico dos quintais e identificar as principais mudanças ocorridas ao longo do tempo com a participação direta dos interessados. Realizei coleta de material botânico, que se iniciou concomitantemente às entrevistas (fevereiro de 2001) e no mês de janeiro de 2002, dei maior ênfase a esta atividade, coletando e contabilizando todas as plantas existentes nos quintais, não me atendo apenas aos relatos e indicações dos moradores. Iniciei a coleta em um quintal, um dos maiores e aparentemente um dos mais diversos, no qual coletei a maior quantidade possível de material para identificação e nos demais quintais eram coletadas as plantas que diferiam e que ainda não haviam sido coletadas no quintal que serviu como base para o início do levantamento. No decorrer de todo o trabalho de campo coletei material botânico em todos os quintais, especialmente quando era encontrado material reprodutivo. Coletei as espécies arbóreas e arbustivas, enquanto que as herbáceas, somente coletei aquelas indicadas e utilizadas pelos moradores. Em relação às ornamentais, algumas vezes utilizei a fotografia como recurso para identificação de plantas que se encontravam em vasos, já que muitas vezes só existia aquele indivíduo e havia também a questão afetiva por parte das moradoras. Para identificação em campo das plantas ornamentais também utilizei os livros Plantas Ornamentais no Brasil; (Lorenzi, 1999), Palmeiras no Brasil (Lorenzi, 1996) e Árvores Brasileiras (1992), e também Dicionário das Plantas úteis do Brasil (Cruz, 1982). O material botânico (vegetativo e reprodutivo) foi depositado no Herbário da ESALQ-USP e identificado por família, gênero e/ou espécie, com o auxílio dos 
professores, alunos de pós-graduação e técnicos que trabalham no herbário da ESALQ. Junto às coletas eram registradas informações referentes a cada planta fornecida pelos moradores, complementando, assim, as entrevistas. Durante as coletas eu procurava detalhar meus procedimentos explicando aos moradores todas as etapas, desde a coleta das partes das plantas e a herborização.

\subsubsection{Confecção de perfis, croquis e levantamento das áreas dos quintais}

Foram feitos perfis verticais em nove quintais. Muitos autores em seus estudos descrevem a estrutura dos quintais primeiramente pela estratificação vertical, com ênfase aos seus principais estratos (alto, médio e baixo) e as funções ecológicas, analisando essa relação com base nos princípios da dinâmica florestal (Lok, 1998b). Contudo, para obter uma análise mais abrangente do conjunto de estruturas, a confecção dos perfis teve como objetivo possibilitar a identificação dos diferentes estratos presentes e relacioná-los às zonas de manejo existentes nos quintais e, assim, obter uma visão tridimensional desse espaço. Os perfis verticais foram feitos em parcelas de 2 a $5 \mathrm{~m}$ de largura por $20 \mathrm{~m}$ de comprimento, por um estagiário Fabrício Tinto, estudante de graduação de Engenharia Florestal, que acompanhou parte do trabalho na comunidade, através da realização de estágio supervisionado pelo Laboratório de Silvicultura Tropical da ESALQ/USP.

Alguns moradores também participaram na confecção dos perfis de seus quintais. Foi 0 caso de um perfil, feito por um dos integrantes de um dos grupos familiares estudados. Entre as atividades das quais ele participou além da confecção do perfil de seu quintal, auxiliou em outros quintais, observando e medindo as áreas e as árvores.

A confecção dos croquis dos quintais possibilitou a visualização e a disposição de diferentes áreas de manejo, dos cultivos em relação à estrutura do quintal e o entendimento de sua forma.

Seguindo esta linha de estudos para a caracterização dos quintais, foram desenhados os croquis e realizadas as medições das áreas em quatorze quintais, sendo que em um destes foi feita também a projeção de copas. Para realizar a medição utilizei trena e as casas foram o ponto de referência e partida. Os limites dos quintais foram definidos por seus moradores que me 
indicavam: "vai até aquela pedra ali...";"acho que vai até o caminho, naqueles pés de banana "; "até a cachoeira"; "Ah! eu plantei este pé de manga e até aqui é meu".

A partir da casa foram traçadas linhas em "forma de estrela" até os limites dos quintais e as benfeitorias, quando presentes, como galinheiros, casas de farinha e etc, foram medidas e demarcadas. As plantas baixas dos quintais ou croquis foram delineados em papel milimetrado em escala que variou entre 1:100 ou 1:200 e depois transpassados para o papel vegetal e gravados em arquivo digital. As plantas baixas em escala foram trabalhadas no programa Auto Cad, o que permitiu a obtenção das áreas aproximadas de cada quintal. Algumas destas plantas baixas ou croquis foram também "montadas" junto com os moradores, tendo como ponto de referência a casa onde foram localizadas as principais plantas e benfeitorias dos seus quintais.

\title{
2.3.6 Calendários das fruteiras
}

\begin{abstract}
"Abacateiro acataremos teu ato, nós também somos do mato, como o pato e o leão, aguardaremos brincaremos no Regato até que nos tragam frutos teu amor teu coração. Enquanto o tempo não trouxer teu abacate, amanhecerá tomate e anoitecerá mamão."
\end{abstract}

Refazenda, Gilberto Gil

Durante o trabalho de campo outra idéia "amadureceu" e resultou na elaboração de um calendário de fruteiras que serviu como um instrumento para obter informações mais completas sobre a produção e aproveitamento das fruteiras presentes nos quintais, assim como informações sobre fenologia, fornecidas pelos moradores.

Elaborei os Calendários das Fruteiras e no Anexo C encontra-se exemplares preenchidos por uma moradora, o material é composto de ilustrações de dezenove plantas, a maioria fruteiras (banana, mamão, goiaba, limão, coco, manga, abacate, laranja, maracujá, jaca, caju, jaboticaba, romã, condessa, jambo, café, urucum, palmito e batata-doce), observadas nos quintais visitados do Mamanguá. As ilustrações foram feitas em aquarela pela desenhista e ilustradora Mônica Stein Aguiar. E em cada página estão presentes as representações da árvore, flores e frutos da 
respectiva fruteira (Figura3), além de outros desenhos que correspondem às informações de interesse a serem coletadas sobre cada planta, como serão comentados adiante.

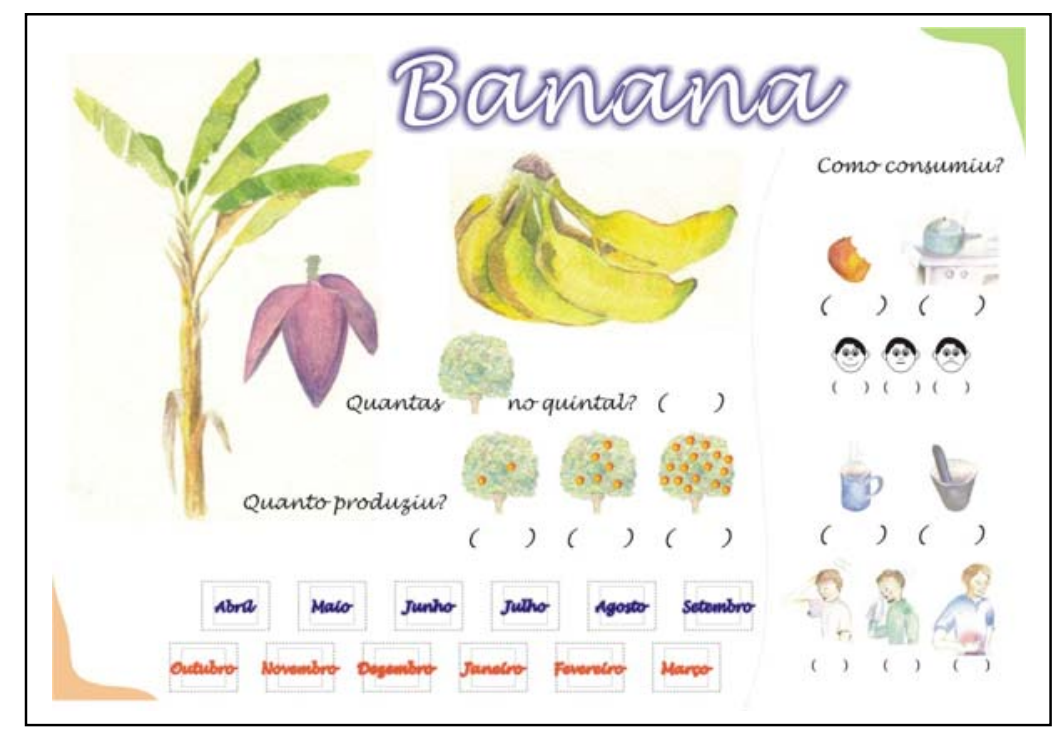

Figura 3 -. Um dos calendários das Fruteiras

O preenchimento dos espaços deixados em branco, permitiu a coleta de dados. Esses espaços correspondiam a um determinado desenho e a respectiva informação desejada, dessa forma, as pessoas foram orientadas para que assinalassem com um $\mathbf{X}$ ou números e assim informaram: (i)a relação de indivíduos da respectiva frutífera/quintal, (ii) produção qualitativa dessa, (iii) forma de consumo de suas frutas e/ou outras partes da planta (in natura ou preparada) e (iv) uso (nesse caso, procurei averiguar o uso de cada planta como remédio). 


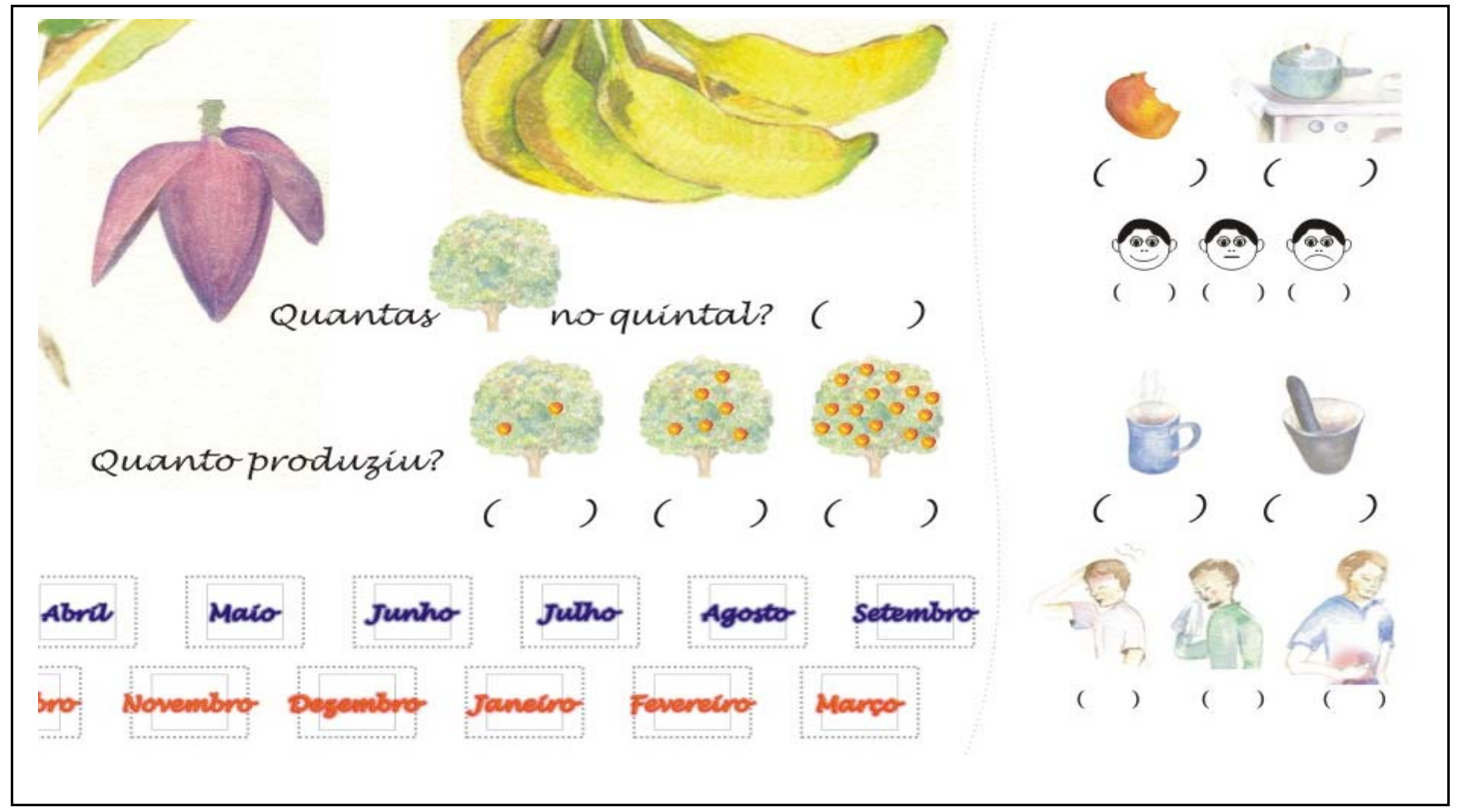

Figura 4 - As informações obtidas com o preenchimento do calendário por fruteira

Os dados fenológicos foram preenchidos com a colagem de pequenas figuras (desenhos de flores e frutas, verdes e maduras) que foram recortadas e distribuídas juntamente com os calendários e cola. Dessa forma, foi orientado para que elas fossem coladas junto ao mês correspondente de sua ocorrência. Os meses foram diferenciados em meses frios (em azul) e meses quentes (em vermelho), segundo a classificação dos próprios moradores.

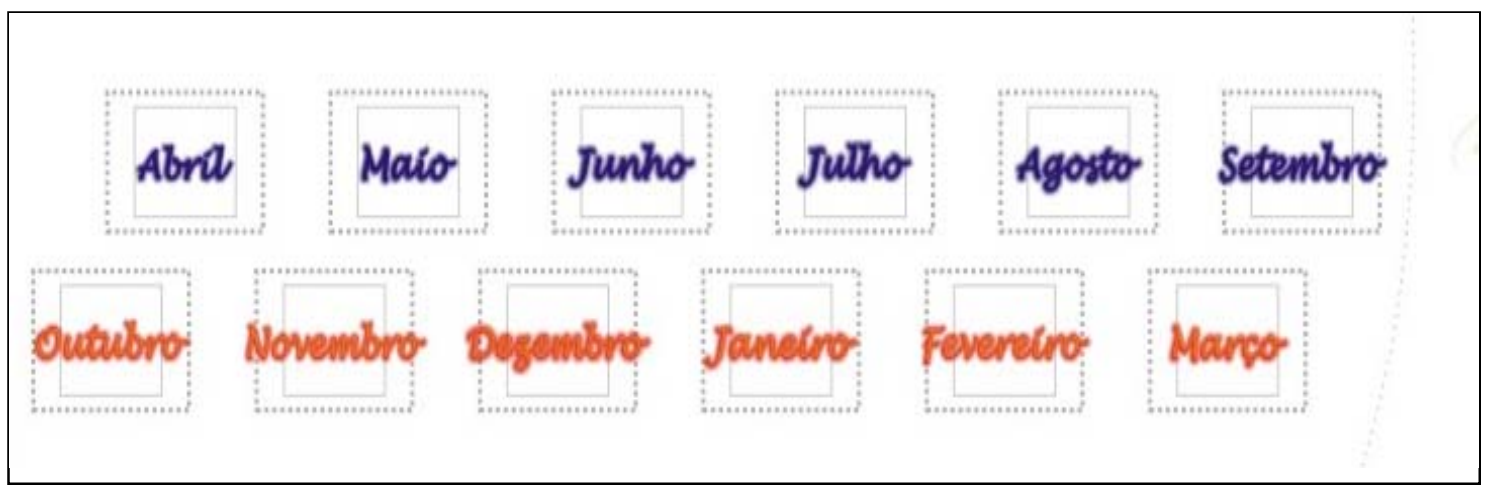

Figura 5 - Os meses que compõem o calendário os quais encontram-se divididos em meses frios e quentes 
As opções apresentadas para colagem no mês referente são as seguintes:

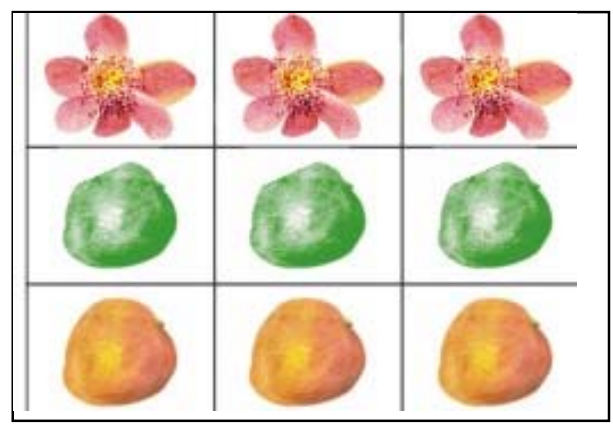

Figura 6 - Flores e frutos para serem colados nos meses correspondentes

Um exemplo de preenchimento sobre a fenologia: em janeiro 0 abacateiro estava com flores e iniciando a frutificação, portanto a figura a ser colada era a que ilustrava uma flor e o fruto verde, como mostra a figura a seguir, (Figura 7):

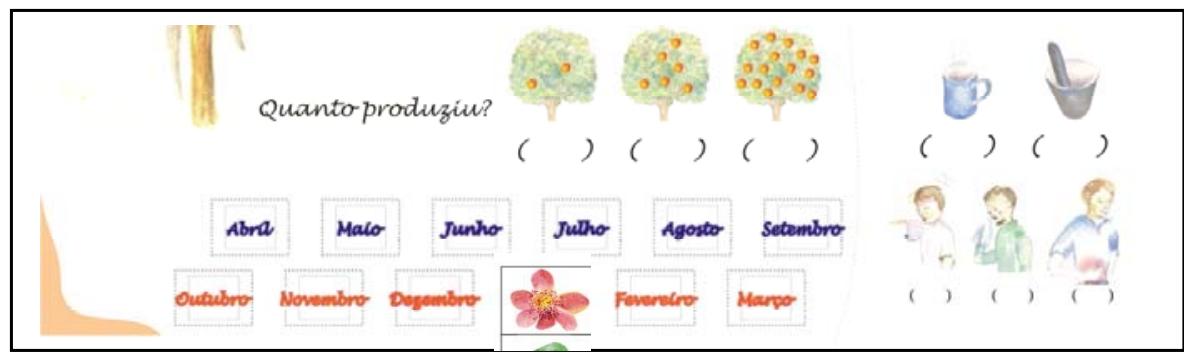

Figura 7 - Exemplo de preenchimento dos dados sobre fenologia

Esse instrumento teve como principal objetivo promover o aumento da percepção do "espaço quintal" por suas moradoras e seus familiares. Busquei fazer esse convite através da beleza, da linguagem simples e lúdica dos desenhos, tentei com isso estimular a participação não-verbal e a maior interação das pessoas, ao despertar o olhar delas para suas fruteiras e para seus quintais.

Os calendários foram entregues em janeiro de 2002, ao entregá-los, folhei todas as páginas e preenchi algumas informações junto com as moradoras e foram conferidas as fruteiras presentes em seus respectivos quintais. Os calendários foram distribuídos em seis diferentes povoados, sendo os seguintes: Regate, Curupira, Pontal, Praia Grande, Ponta da Romana e 
Cruzeiro e alguns casos, o mesmo calendário foi preenchido por integrantes de diferentes famílias. Entres as senhoras que preencheram 0 calendário duas eram responsáveis pela merenda escolar da escola pólo do Saco do Mamanguá.

Em um dos momentos, após a entrega do calendário e a explicação sobre 0 preenchimento do calendário em das uma casas, fiquei na varanda conferindo a listagem das plantas que haviam sido coletadas. Neste momento chegou outra senhora que comentou com a dona da casa sobre as figuras e a forma de preencher. Fiquei feliz ao escutar a explicação de uma para a outra de como deveria ser feito o preenchimento e o comentário "que seria fácil, que ela sabia fazer, sim". Em novembro de 2002, os calendários foram recolhidos, totalizando quase onze meses de coleta de informações.

Entreguei um exemplar na Secretaria Municipal de Educação e também estimulei o uso dos calendários na escola como instrumento didático, para isso elaborei junto com os professores atividades que poderiam ser desenvolvidas com os alunos através desse instrumento.

\subsubsection{Levantamento da dieta familiar}

Para realizar o levantamento da dieta familiar na comunidade do Saco do Mamanguá, foram feitas nove viagens a campo. Nestas viagens foram feitos 104 levantamentos sobre a dieta familiar com o total de 208 refeições principais (almoço e jantar) 208 complementares (desjejum e lanche), em dezenove famílias, no período de janeiro de 2001 à março/abril de 2002. Nesses levantamentos foram verificadas a origem e a freqüência dos gêneros alimentares através do método Recordatório 24 horas (Dufour \& Nicolette; Quandt) citado por Hanazaki, (2001). Esse método consiste no levantamento de todos os itens que os grupos consumiram nas refeições realizadas nas últimas 24 horas, contando a partir da última refeição até o momento da entrevista.

Esses levantamentos, além de verificar a freqüência e quais alimentos foram produzidos nos quintais que estavam presentes na dieta das famílias, obteve também informações sobre as relações "comerciais" de trocas e de parentesco dentro da comunidade. Informações sobre a utilização de outros sistemas ou recursos como a roça, o mar e a floresta, assim como quais alimentos que foram comprados em supermercados/armazéns na cidade de Paraty. 
Todas as informações e resultados obtidos no decorrer de dez viagens a campo (ver Anexo D, o Quadro com as viagens e atividades desenvolvidas), foram sistematizados em um banco de dados do programa Access e trabalhadas em Excel. Em Parte dos resultados utilizei o programa Statistica e realizei uma análise não-paramétrica, Komogorov-Smirnoff, para comparar as categorias de uso entre o grupo de quintais que estão localizados na APA com os que estão inseridos na REJ, assim como o grupo de quintais localizados no fundo com aqueles que estão localizados mais na saída do Saco do Mamanguá, onde há maior influência do turismo. A seguir serão apresentados todos os dados obtidos juntamente com a análise e discussão. 


\section{RESULTADOS E DISCUSSÃO}

\section{Encanto caiçara}

Venho de campos e matos terra verde, fértil e farta. Nossa roça à beira-mar. Canto a pesca e canto a planta $E$ a vida santa do lugar. Jucá acordando cedo, visitando o cerco e Manezinho saindo pra tirar taquara.

E nos olhos da caiçara um riso, uma beleza rara.

E a natureza não pára, é tanta história pra contar... Lá da casa de farinha uma voz sozinha vem soprando um canto e solta pelo vento manso nossa história pelo ar.

$E$ quem pensar que o meu canto terminou aqui não viu $q$ que não falei da rama, a planta da mandioca, o peixe e a banana, a massa e o tapiti.

E nem da casinha de palha.

Um porco na ceva, um quarto de lua, um cio de água e um peixe na malha.

E nem na viola do Dito, na tarde de um dia bonito.

Um azul-marinho é um pirão de gonguito Uma cachaça boa e a gente cantando, poesia brotando pelo chão do peito e esse canto é feito pra quem quer morar nesse encanto do meu canto caiçara. É camarão no covo, criança na praia remendando rede, reunindo malhas prá cercar o peixe e fartar a casa. E mariscar maré rasa... 


\subsection{No Vai e vem das águas do mar, diferentes tempos a desvendar}

"O tempo dos antigos, o tempo de hoje, o tempo da natureza, o tempo de ganhar dinheiro, o tempo dos turistas, tempos de transição, o tempo da Ecologia, o tempo da memória e o tempo da fartura"... Inicio fazendo alusão a todos esses tempos revelados nas falas dos caiçaras, citados por Diegues \& Nogara (1994); Sanches (1997) e Mansano (1998). Essas falas revelam que não somente espaços diferentes são reconhecidos, como também diferentes tempos e que traduzem as mudanças sentidas por essas populações (Diegues \& Nogara, 1994).

Diante dos fatos que vão deixando suas marcas na vida e reconhecidos no decorrer do tempo, vou tentar fazer o diálogo entre a bibliografia consultada, (em que os autores descrevem, às vezes, coincidentes histórias sendo que em muitas delas, o que muda simplesmente são os "atores ou os cenários"), com as falas destacadas, garimpadas, através das entrevistas e observações feitas no tempo que passei com as famílias do Saco do Mamanguá. Esses depoimentos foram transcritos ao diário de campo fazendo referência aos tempos que são assim percebidos por essas pessoas.

Ao abordar o contexto histórico dos caiçaras do bairro rural de Cambury, Mansano (1998) refere-se à velocidade das transformações que intercruzaram os tempos "dos antigos" e o "de hoje", e entre um e outro, está o que ela denominou de "tempo de transição", marcado por mudanças sócio-econômicas e culturais profundas, intimamente ligadas aos ciclos econômicos e ações públicas do século passado. As transformações se deram de forma tão veloz, que a sensação é que o "tempo dos antigos" já foi a muito tempo atrás... Contudo, as mudanças mais relevantes ocorreram somente a trinta, quarenta anos atrás.

No caso do Mamanguá o "tempo dos antigos", corresponde ao "tempo da fartura" citado pelos moradores e segundo Diegues \& Nogara (1994), a década de 40 constitui-se num referencial simbólico desse tempo. Durante o período de pesquisa, constatei também em muitas falas, em especial das pessoas mais velhas, a lembrança de episódios que remetiam ao que é chamado por eles de tempo da fartura, tanto no que se relaciona aos plantios e à pesca, como também ao trabalho coletivo, contudo, nas falas por mim coletadas esse tempo se relaciona aos fatos que ocorreram entre as décadas de sessenta e setenta. 


\subsubsection{0 tempo da fartura, o tempo de agora e a roça}

"Se a gente fosse contar como era aqui antigamente, ia ficar a tarde toda...

Tinha muita fartura, muito trabalho, pra conseguir as coisas, era tudo

com muito esforço, como muito sacrifício..."

Os trechos retirados do diário de campo são recortes em que os interlocutores (as) falam sobretudo do trabalho na roça relacionado ao "tempo da fartura". Em muitos depoimentos as pessoas apontam mudanças e que muitas vezes estão relacionadas com as formas de uso da terra e fica mais explícito no uso/desuso da roça. Existe um certo saudosismo, a lembrança em que os morros eram cultivados e as pessoas trabalhavam a terra, a "época da fartura". Em um dos povoados alguns moradores apontam a encosta dizendo: "Nesses morros todos há 30 anos atrás era tudo roça e agora é mata virgem".

O cultivo de roças diminuiu drasticamente segundo alguns depoimentos, mas ainda é possível encontrar famílias que as cultivam no Mamanguá e muitas vezes apenas para consumo próprio. Entre os dezenove grupos familiares estudados, oito famílias ainda possuem suas roças e três grupos realizam plantios esporádicos, portanto, na ocasião do trabalho de campo, onze famílias mantinham suas roças, ainda que mais timidamente em relação ao passado. Sendo que destes, quatro possuem pequenos plantios de aipim e mandioca em continuidade aos seus quintais, e na maioria das vezes a roça localiza-se distante dos quintais. Já os outros setes grupos cultivam a mandioca para produção de farinha e seus plantios estão distantes da casa. $E$ entre as famílias entrevistadas, há ainda uma família que comercializa a farinha externamente, as demais fazem a roça apenas para consumo próprio e para alimentação animal (geralmente galinhas), o excedente, ou é comercializado entre vizinhos e parentes, ou ainda são mantidas relações de troca de produtos entre as famílias (e que também pode ser a mandioca pela farinha). Além dos grupos familiares, com os quais interagi diretamente nos povoados visitados durante a pesquisa, há ainda segundo relatos dessas pessoas, cerca de mais quatro famílias que ainda colocam roça na parte peninsular do Saco do Mamanguá, na REJ. Já no lado continental, aproximadamente de cinco a seis famílias também ainda fazem plantios para consumo próprio ou pequena comercialização, nos mesmos povoados do presente estudo. 
Já a casa de farinha está presente em cinco dos quintais estudados, em alguns casos mais de um grupo familiar utiliza o mesmo paiol (outro nome para casa de farinha). A farinha de mandioca é produzida nos meses frios que vai de abril a agosto e o plantio se inicia em agosto e vai até outubro/novembro. Antes é feita derrubada da capoeira, a queima e depois o plantio. Foram citadas muitas variedades de mandioca e aipim ${ }^{19}$, como: landi, aipim preta, aipim vermelha, aipim seda, maricá, caravela, bahia, amargosa, tupã, varetinha, gongá, aipim rosinha e aipim manteiga. Geralmente se planta mais de uma variedade nas roças, de acordo com a finalidade e com a terra. Foram citados também outros tipos de cultivos na roça, como bananas, abacaxi, café, abóbora, laranjas, quiabo, feijão, e a presença do ingá, que era plantado em consórcio com o café, segundo relatos dos entrevistados.

Durante o campo a listagem de espécies/variedades (tanto dos quintais como das roças) foi crescendo, e em cada relatório pronto, eu costuma levar para discutir com as pessoas essa listagem que ia se formando. Em uma tarde, em uma dessas cabanas para canoas na beira do mar, sentamos vendo a tarde quente e limpa cair devagar por detrás das montanhas. 0 clima era de muita descontração, além das boas conversas, cantamos músicas ("...beira do mar, lugar comum...") e então abri o relatório e mostrei quantas variedades de mandioca já haviam me falado e também observado... E durante essas boas conversas foram então acrescidas outras variedades de mandioca e aipim que um e outro ia lembrando (estávamos em um grupo de mais ou menos seis pessoas, entre homens e mulheres, sem falar nas crianças) e o nome das variedades de mandiocas ou aipim, muitas vezes estão relacionados com o lugar de onde 0 camarada trouxe a planta, ou alguma característica específica, como cor, tempo de produção, tamanho e etc... Portanto, mais onze variedades foram citadas, isso não significa que todas eram cultivadas naquele momento na comunidade, expuseram apenas as que conheciam e que já tinham tido contato, tais como: varetinha (em oito meses já dá raiz) da vermelha e branca, ruivinha, perna de saracura (rama comprida), landi branco e preto, aipim santista, aipim amarelinha, aipim bordão São Pedro, aipim senta na mesa (muito mole, quando se cozinha já pode sentar na mesa que logo ela fica pronta) e sete folhas. Totalizando vinte e cinco variedades citadas pelos entrevistados.

\footnotetext{
${ }^{19}$ A diferença entre mandioca e o aipim é que a primeira serve somente para a fabricação de farinha, enquanto a outra serve para comer cozida e também fazer farinha, segundo o relato dos moradores.
} 
Quando indagava aos moradores sobre as dificuldades atuais de plantar a roça, dois principais problemas me foram apontados: um, citado por muitos entrevistados, foi a seca que se fez presente durante o meu trabalho de campo (2001-2002) e o outro também bastante citado, foi a terra que está fracassando, isso em conjunto com a perda de território para os veranista/proprietários de terra e alguns falam ainda da existência do IBAMA, como um problema às suas práticas da roça, principalmente nas várzea, próximas ao Rio Grande na área da REJ.

O termo "fracassou" é usado quando as pessoas se referem a pouca produção ou à razão do não-plantio, as terras boas estão cada vez mais distantes e difíceis de serem cultivadas. Muitos dos entrevistados que praticam o plantio, já estão idosos e vivem atualmente com a aposentadoria ou exercem outras atividades relacionadas ao turismo (como transporte e jardinagem). Os jovens, segundo os depoimentos, não demonstram interesse na roça, dão preferência às atividades remuneradas, porém quando há produção de farinha pela família, todos contribuem nas atividades.

"Tanto a pesca como o serviço de caseiro, trabalha-se menos e ganha mais do que na roça. A farinha é uma coisa tão boa e tão ruim, porque se tiver duas pessoas na casa, ocupa 0 trabalho delas. E se tiver dez pessoas, também vai ocupar o trabalho delas. Porque a farinha dá muito trabalho" (trecho retirado do Relatório da disciplina "Manejo Florestal por populações Tradicionais", apresentado pelo grupo que estudou as roças no Mamanguá)

- E como era antes, no tempo da fartura?

As famílias que faziam grandes roças contratavam os "camaradas" para ajudá-los no plantio, pois tinha muito serviço, e nesse caso não só os integrantes da família se ocupavam das tarefas, de plantar a mandioca, fabricar a farinha e vender em Paraty e llha Grande e Angra dos Reis, a seguir um trecho do diário de campo junto com parte de uma entrevista que descreve esta situação.

(...) Na roça, recorda, tinha mandioca, feijão, milho, melancia. Sua família vendia farinha de mandioca para Angra dos Reis e Ilha Grande, que era transportada em canoas de voga. A família chegava a fazer $60 / 50 \mathrm{~kg}$ por dia de farinha, há mais ou menos 40 anos atrás: 
"Naquela época era tudo uma fartura, tudo tão lindinho". Secava o feijão no terreiro, peneirava e depois ensacava e guardava na casa. Farinha de milho, canjica, nós não comprava, o café, pra adoçar o café, era com o melado da cana, não tinha açúcar. Nós tinha o pilão e colhia o café, torrava e moía pro consumo. Nós passava o dia todo na roça, então de manhã, acordava, fritava o peixe e levava o café, mais as coisas da roça, era esta nossa comida quando se ia para a roça, às vezes levava feijão e a farinha".

- E como é o tempo de agora?

"Agora as roças estão fracassando, antes, de julho a agosto o que se via era toda gente colocando fogo e preparando a terra, a melhor época de plantio é setembro. Hoje já não se vê mais ninguém preparando a terra com antes. Hoje ninguém mais faz farinha, são poucas as famílias que ainda fazem e têm roça".

Quando eu pergunto qual tempo era melhor não fica claro para mim, parece que apesar das dificuldades, identifico um certo saudosismo dos tempos antigos, do tempo da fartura, mas as facilidades de hoje são bem vindas, mesmo porque ao se referirem às atividades da roça sempre falam de um trabalho muito duro, e muitos deles, já não têm mais saúde para estas práticas. Mesmo que quisessem trabalhar não podem ou não vale à pena. Sem falar nas terras que estão sendo vendidas...

"...é mais fácil comprar do que fazer a roça, o feijão tem que "munizar"... (imunizar) Antes os mais velhos não tinham dinheiro, hoje tem aposentadoria e outras atividades que dá dinheiro. 0 milho se colher demais tem que vender. Não compensa vai perder muito tempo, até preparar a terra e quem compra da gente não paga nada e vende pelo dobro".

"Como é que pode? Gente da roça comprá tudo na cidade, será que não pode plantar num pedaço de terra(?) e come tudo com veneno, o tomate é muito diferente, é aguado, as sementes ficam soltas. (...)."

$\mathrm{E}$ a sabedoria da terra fica predominantemente com os antigos, com aqueles que através dos tempos continuam a afagar terra e dela tirar o seu sustento. As falas que coloco a seguir é de uma senhora de setenta e poucos anos, a matriarca de uma família de pescadores, que não seguiram os passos dos pais agricultores e saem em embarcações para 0 alto mar e mesmo as 
filhas casaram-se com pescadores, a família reside no povoado do Cruzeiro, onde moram a maioria dos pescadores embarcados.

"A gente tem que saber o mês para plantar, tenho cará, eu sei qual é a terra, se eu plantar na terra vermelha eu não vou colher, tem que plantar em terra preta, perto da cachoeira, aí vai dar. Se planta em julho, agosto, setembro, outubro e aí já está brotando"

“(...) Eu planto tudo, até hoje eu ainda tenho minha roça, planto meu cará, o aipim, melancia, pepino, cenoura (...). As "crianças" falam que eu não tenho mais idade, mas eu quero plantar e gosto, outro dia levei meu filho, pra ele me ajudar a colher o cará e a gente colheu dois sacos cheios de cará. Ele falava que não tinha mais nada e eu fui mostrá pra ele o que tinha, e ele se admirou do que a gente colheu lá." Eu vendi e dei pra muita gente o cará".

\subsubsection{A mesma estrada que leva, traz... 0 homem do mar e da terra chega à cidade e o homem da cidade chega ao mar e compra a terra. ${ }^{20}$}

Os relatos por mim coletados estão relacionados a uma época não muito distante, aproximadamente no final dos anos sessenta e início da década de setenta, quando se deu também a abertura da BR 101 e talvez quando um conjunto de mudanças estruturais mais relevantes torna-se mais evidente para as populações do litoral. Conhecida também como a "Estrada da redenção", responsável pelo escoamento da produção econômica entre as duas maiores cidades brasileiras, veio acoplada ao Projeto "Turis", elaborado pelo governo federal em 1973, que reconhece o valor turístico da região, colocando Paraty em destaque e torna-se responsável pela inserção do caiçara no mercado do turismo. Mas trouxe também uma multidão de grileiros e especuladores interessados em expropriar o caiçara da terra entregando-a às grandes empreendedoras (Calvente, 1992). Por outro lado, o acesso agora facilitado aos centros de consumo, trouxe conseqüências que foram percebidas de forma gradativa nas comunidades caiçaras, principalmente em lugares como o Saco do Mamanguá, já que mesmo nos dias atuais, 0 acesso é difícil.

A chegada da estrada Rio-Santos sem dúvida foi um dos fatores que modificou 0 cotidiano caiçara. Luís Perequê, um artista caiçara de Paraty, relata esse fato de forma

${ }^{20}$ Com a atividade turística, a terra surge como uma lucrativa possibilidade de reserva de valor para o capital, diferentemente do seu valor para o caiçara, a terra só possui valor quando produz. (Calvente, 1992, p. 32). 
poeticamente peculiar, desmembrando a palavra desenvolvimento e fala do des-envolvimento, (contrapondo-se ao envolvimento) das pessoas em relação às suas atividades e ao seu lugar, pois até então as populações caiçaras daquela região tinham uma vida muita adaptada às características das florestas, rios e mares. Era uma vida intensamente envolvida com a natureza, com o seu lugar.

A partir dessa formulação crítica que é expressa nas canções desse artista, Viana (2002) realiza uma nova reflexão sobre o conceito do desenvolvimento sustentável, na qual "envolver", segundo 0 autor, é a antítese de des-envolver e propõe a discussão sobre o conceito do "envolvimento sustentável" e questiona: "Está o conceito de desenvolvimento equivocado?" E segue propondo uma reflexão, que pode ser subsidiada com base numa perspectiva caiçara sobre o real significado do des-envolvimento, que segundo a ótica do compositor caiçara, está vinculado ao fenômeno da abertura da estrada-turismo, a BR 101.

Porém, além do acesso facilitado ${ }^{21}$ aos centros de consumo por parte dessas populações, pela abertura da estrada, outro fenômeno que se tornou cada vez mais presente e atualmente merece atenção pelos caiçaras, foi o turismo, que começou a atingir as comunidades litorâneas durante essa mesma época. A mesma estrada que facilita 0 acesso das populações aos centros mais urbanizados, retirando o caiçara do relativo isolamento, também traz o turista, fatos que colocam a perspectiva de novos hábitos e novas possibilidades de consumo. Muitos caiçaras passaram a consumir produtos advindos da cidade.

"A gente acordava, moía a cana, e fazia o café de cana, que era fervido com o caldo da cana. A banana cozida ou então 0 aipim era o que a gente costumava fazer para acompanhar, ou então misturava o café com farinha de mandioca. A gente fazia canjica, tinha milho, plantava também feijão, e se comia com o peixe que era salgado e seco nos terreiros, acompanhado da farinha de mandioca."

${ }^{21} \mathrm{O}$ acesso facilitado atualmente significa para a população que reside no lado continental do Saco do Mamanguá, a caminhada por uma trilha, de aproximadamente 1 hora e meia até a Vila de Laranjeiras, que após a construção do grande condomínio de luxo de Laranjeiras, é servida por algumas linhas de ônibus que ligam principalmente à Paraty. Em dias de chuva esta trilha fica praticamente intransitável e precisa ser limpa constantemente. No caso da população que vive na parte peninsular, as pessoas ainda dependem diretamente de embarcações para realizar o transporte e chegar na parte continental, à Paraty-Mirim ou ainda à Paraty . 
Esse depoimento descreve uma cena cotidiana e que ainda revela elementos da alimentação ligada diretamente ao uso dos recursos locais e oferece traços de como era a dieta básica do caiçara (que será discutida adiante mais profundamente), também remete ao tempo da fartura, em que tudo era produzido no lugar, mesmo diante de todas as dificuldades colocadas pelos informantes e sempre atreladas aos depoimentos.

Muito pouco era comprado, o dinheiro era escasso, comprava-se apenas o sal, a querosene, ração para os bichos, segundo relatos dos moradores, e que também é citado por Adams (2000). Muitas vezes nas falas é citada a forma simples de viver a vida, "sem muitos luxos". E o prazer que a atividade do plantar proporciona (va), fica expresso no olhar e implícito no falar das pessoas que ao contarem sobre os tempos antigos, comentam a mudança diante das facilidades oferecidas hoje em dia e o comportamento dos mais jovens:

"E hoje quem é que quer acordar de manhã e fazer café de cana, moer a cana?"

O açúcar compra na cidade, tudo se compra na cidade, é mais fácil."

"Hoje as pessoas estão todas "ricas", ganham $R$ \$20,00/dia e ainda acham pouco, a gente criou nossos filhos com muita dificuldade, a gente ia na cidade e trazia um pouquinho de cada coisa: sal, querosene, tecido, sabão em pedra e se trocava muito as coisas entre as pessoas, pedacinho de sabão, sal....Não se tinha móvel nas casas, hoje o pessoal tem e quer mais..."

"Hoje em dia gente mais nova não quer saber de roça não". Ninguém quer mais saber, só os mais velhos mesmo que ainda lidam com a terra, fazem farinha. $E$ a gente mesmo que quisesse, não dá mais pra fazer roça..."

- Por que a terra "fracassou"? (perguntei)

"Não, por causa dos turistas que compra a terra e a gente não pode mais usar, eles cercam e os caseiros não deixam a gente pegar pau lá, nem mexer em nada e atrapalha os caminhos..." 


\subsubsection{0 que trouxe o turismo}

Como Já foi colocado por Diegues \& Nogara (1994), a opinião dos moradores do Mamanguá sobre a chegada dos veranistas se divide, ou então, estes conseguem perceber os pontos positivos e negativos nessa nova relação como é confirmado nos relatos que seguem, ao responderem a questão: 0 que aconteceu com a chegada do turista?

"Veranistas trouxeram emprego, deu dinheiro pro caiçara, ninguém tinha dinheiro, por isso foi muito bom".

"Hoje temos casas mais arrumadas... mas o que queremos é a melhoria das escolas e as gerações futuras vão precisar sair pra procurar emprego"...

"É bom ter turista porque dá serviço para as mulheres e para os homens. Antes as mulheres não tinham dinheiro".

"O impedimento do caminho do litoral, eles fecharam as passagens para chegar nas praias, colocaram cachorros bravos e arame farpado... Os caminhos do litoral, são caminhos do caiçara, que não tem muro, cachorro bravo. Antes eu andava por esses caminhos todos, ia andando até Ubatuba, hoje em dia não existe mais o caminho. (...) Os veranistas podem fazer marina, mas os pequenos não podem".

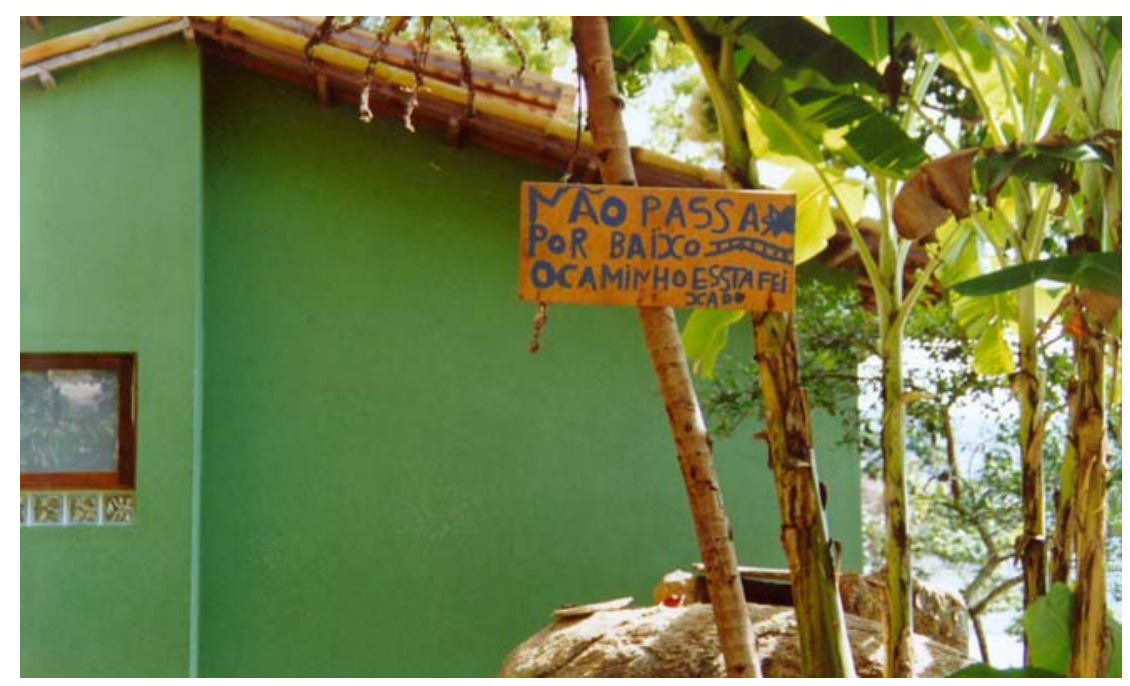

Figura 8 - Placa colocada pelo caseiro, proibindo a passagem do caminho costeiro 
Outra conseqüência logo sentida com a chegada do turismo, está relacionada ao fato de muitos moradores perderem efetivamente suas terras, iludidos com a obtenção do "dinheiro fácil", resultante da venda de suas posses e que em muitos casos, foram vendidas por um valor inferior do que realmente valiam (Silva, 2001). Aqueles que venderam foram morar em Paraty e são criticados pelos que ficaram, por viverem também de forma miserável e também por não poderem mais votar ao lugar, pois não têm mais casa ou terra e com isso chegou também a consciência do que era des-envolver (Diegues \& Nogara, 1994 e Viana, 2002)

Com a venda das terras para os veranistas, principalmente as áreas de costeira e praias, as casas são "empurradas" morro acima e estão mais próximas, sem plantios e com isso 0 espaço nos terreiros também diminuiu, conforme relatos:

"Hoje a família é maior e o quintal diminuiu". "Ter o quintal é bom porque dá o direito de fazer 0 que quer".

"Muita coisa mudou. O certo é não vender a propriedade, mas eles ficam iludindo, falam que o terreno é do turista e o Cid Ribeiro22 fala que é dele. A comunidade estaria como era antes, tinha roça e cana. Os mais novos modificaram, preferem trabalhar como caseiro. Há trinta anos atrás só se via roça de mandioca nesses morros, era cana e mandioca".

Entre os povoados que visitei durante meu trabalho de campo, a Ponta da Romana, é onde se observa o maior aglomerado de casas mais próximas e com características diferenciadas do resto do Mamanguá, com a presença de muros ou cercas, o chão encontra-se cimentado e com espaços pequenos entre as casas caiçaras e com poucos plantios (ou inexistentes), com a predominância de plantas ornamentais (muitas vezes em pequenos vasos) e grama, como é possível ver nas Figuras 9 e 10. Na primeira figura, a foto aérea do povoado e em seguida uma aproximação, mostrando os quintais. A Ponta da Romana e a Praia Grande são, dos povoados estudados, os que possuem também mais casas de veranistas. Este fato talvez se justifique inicialmente pela localização geográfica. Os lugares citados apresentam melhores praias, pois estão mais distantes do mangue, onde a água é mais turva devido à presença de matéria orgânica. Contudo, este quadro está se modificando rapidamente com grandes

\footnotetext{
${ }^{22}$ Referência a um dos grandes proprietários de terra no Mamanguá.
} 
empreendimentos espalhados por todo o Saco do Mamanguá, inclusive na área de Reserva (Baixio, Cruzeiro e entre Ponta da Romana e Cruzeiro).

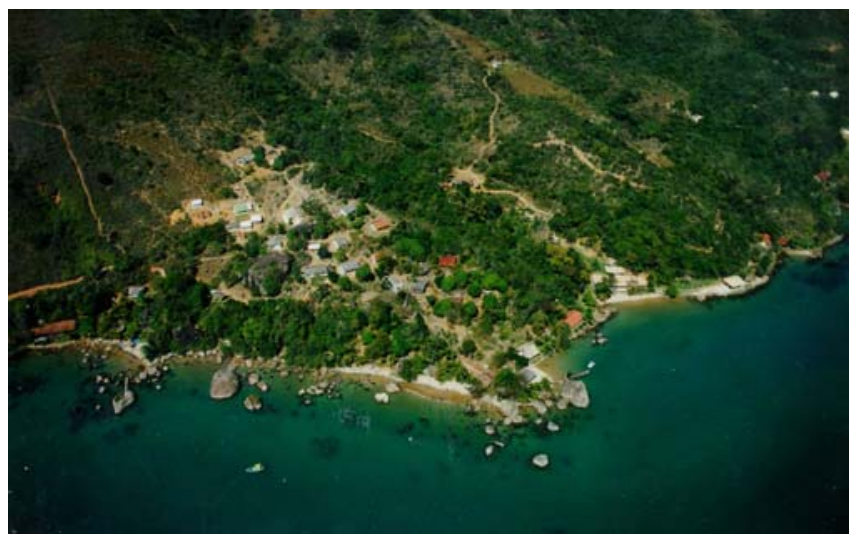

Figura 9 - Vista aérea do povoado da Ponta da Romana, foto cedida pela SOS Mata Atlântica.

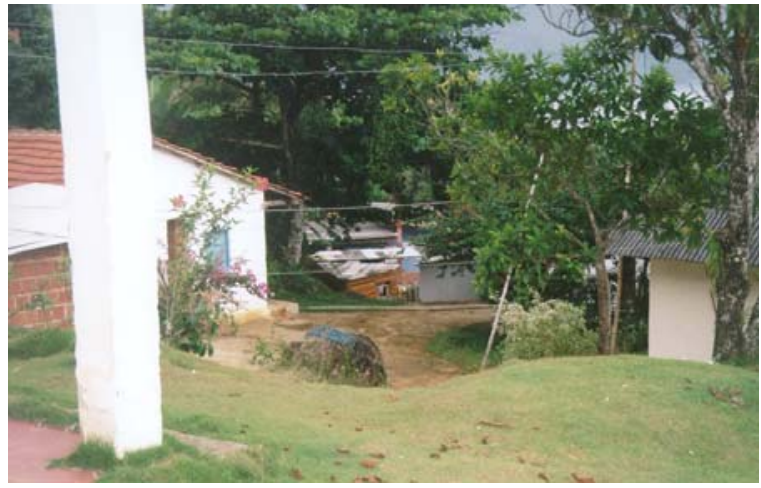

Figura 10 - Foto detalhada dos quintais no povoado da Ponta da Romana

De acordo com o Decreto de lei n0 17981 de 30 de outubro de 1992, que criou a Reserva Ecológicada Juatinga, na qual a margem peninsular do Saco do Mamanguá está inserida, a Reserva é de natureza non edificandi. Muitas vezes as áreas protegidas por leis e fiscalizadas pelo Estado são exploradas pela iniciativa privada que aproveita a estrutura pouco eficiente do Estado para melhor lucrar com isso (Silva, 2001). E seguindo a idéia que a atividade turística, principalmente nos escritos da década de 50 a 70 , elaborados basicamente por economistas, é 
tida como uma grande alternativa para solucoionar uma boa parcela do problema econômico da humanidade (Silva, 2001). Esta atividade vai ganhando terreno na região, mesmo em áreas protegidas por lei, espalhando suas "hifas", penetrando suavemente e burlando a fiscalização do Estado. Na APA, em 2001 dois terrenos adjacentes, antigas posses foram vendidas para veranistas no fundo do Saco.

Estes terrenos têm acesso a um dos principais cais e estão próximos a uma antiga estrada que leva à Vila de Laranjeiras. Os compradores são condôminos do Condomínio Laranjeiras e que têm grande interesse na área, como opção para uma possível marina. Ainda havia a intenção de compra de outros terrenos por outros condôminos, o que no futuro poderia configurar-se em um pequeno condomínio. Em um dos terrenos comprados, segundo as conversas dos moradores, existia um projeto para a construção de quatro casas, deck e um cais particular, que sorrateiramente poderia também dar margem a tão esperada marina opcional aos condôminos, como outra forma de acesso para suas embarcações para não chegarem apenas por mar aberto, que em tempos de "mar grosso" este é praticamente impossível.

Com a chegada do turismo outro problema observado e também muito comentado pelos moradores foi a água. Pode chegar a falta, em períodos de seca prolongada, como a registrada durante parte do trabalho em campo (2000 a 2001). Os moradores do Saco do Mamanguá, captam a água que vem das cachoeiras e nascentes, através de grandes borrachas pretas. Muitas vezes com a venda das terras, algumas dessas cachoeiras, localizam-se em propriedades de veranistas, que começam a controlar o recurso através de regras.

Durante meu trabalho em campo presenciei essa situação, em que um antigo proprietário de terra (veranista) da Praia Grande, forçou parte da população dessa praia a "obedecer" suas regras, tornando-se o único a captar água em uma das nascentes que abastecia praticamente toda a população, ao represar e canalizar a água. Como se ainda não bastasse, esse mesmo proprietário, mandou que desmatasse parte de uma área de mangue, todas essas atitudes, intensificaram nessa ocasião, os conflitos com os moradores caiçaras, que já havia se iniciado com a proibição da passagem do caminho costeiro, o que nenhum morador estava de fato disposto a aceitar.

Nesse caso, o proprietário e sua família ocupam praticamente toda a extensão da praia (como em outros localidades), os moradores subiram para o morro e por fim, o acesso está 
condicionado às vontades daquele que veio de fora, embora o conflito reflita o descontentamento e a não aceitação dessas regras e até mesmo pequena mobilização de quem sempre esteve acostumado a obedecer.

E aí o caiçara vê-se frente a sua nova realidade, reconhecendo que nesta nova relação com o turismo, há também entre os pontos negativos, os positivos. E estes estão relacionados principalmente com aquisição de bens, através da venda de seu trabalho ou até mesmo da sua posse, contudo, muitas vezes paga-se também um preço alto, e o que fica mais evidente e o que eles mais temem é a perda do que tanto apreciam em seu lugar, o sossego, a liberdade, como é relatado em muitas falas.

\subsubsection{O Mamanguá nos tempos do agora}

"Se, pelo contrário, a minha opção é libertadora, se a realidade se dá a mim não como algo parado, imobilizado, posto aí, mas na relação dinâmica entre objetividade e subjetividade, não posso reduzir os grupos sociais a meros objetos da minha pesquisa." (Freire, 1981, p.35).

Estudar os quintais propiciou o acesso direto às famílias, foi preciso antes de qualquer coisa adentrar em suas casas e muitas vezes o tema "quintal" tornou-se a ponte para a discussão sobre tantos outros e diversos assuntos, ligados ao cotidiano e aos dramas diários familiares ou coletivos. Como já citado, a comunidade onde foi desenvolvida a pesquisa encontrava-se sob fortes pressões, sejam elas por questões externas como, por exemplo, o avanço do turismo e a reclassificação da REJ, como por questões internas, que a cada momento exigia dos moradores (as) posicionamentos diante de situações não muito claras. "Verdades" eram estabelecidas e que muitas vezes eram construídas a partir de "boatos". Os diferentes atores envolvidos exprimiam interesses diversos, expectativas e desejos. Estas circunstâncias refletiram a pouca informação e a quase inexistente comunicação, se não fosse a "fofoca", muito comum em pequenas comunidades, onde os fatos acontecidos são comentados por todos em diferentes famílias e distâncias. Situações que deixara claro o relativo isolamento e também muitas vezes a marginalidade destas populações em relação ao sistema vigente e às decisões que são tomadas por instituições governamentais ou por outros agentes. 
Antes de iniciar a caracterização dos quintais vou descrever o que pude perceber e entender do panorama e a dinâmica sócio-ambiental do lugar no momento em que realizava a pesquisa de campo. $O$ que foi vivenciado por mim através das discussões realizadas entre um cafezinho e outro e que por muitas vezes tomaram grande parte das conversas nas visitas realizadas às famílias, nas portas das casas, das escolas e das igrejas ou em reuniões comunitárias.

Vou relatar as condições e os fatos, que ao meu ver são conseqüências da chegada do turismo, do contato com os centros urbanos e a legislação ambiental, que naquele momento tornava-se mais uma vez uma incógnita e ameaçava as pessoas que queriam continuar a viver no lugar. E ainda, como a comunidade e os demais atores estavam submetidos e envolvidos por esses fatos e condições, assim como as ações por eles desencadeadas durante o tempo em que foi desenvolvida a pesquisa de campo.

\section{O isolamento}

O isolamento como uma condição, não se encerra em si mesmo apenas por sua conotação geográfica. Ele permeia várias outras situações e atinge a vida de muitas famílias. 0 isolamento pode ser traduzido também na inexistência ou ineficiência da informação/comunicação. E que de fato influenciou em muitos dos conflitos que serão colocados a seguir.

Ao perguntar para alguns moradores qual era o sonho individual ou o sonho coletivo, muitos respondiam ou mesmo comentavam sobre situações que refletiam esta condição de isolamento geográfico. O sonho da estrada ou formas de deslocamento mais facilitadas esteve presente em muitas falas, já que só é possível chegar à comunidade do Saco do Mamanguá por barco ou por terra através de trilhas.

Uma destas trilhas era uma antiga estrada localizada no fundo do Saco do Mamanguá e foi aberta há mais ou menos uns 30 anos, quando ainda eram desenvolvidas atividades na fazenda por onde esta passava. Atualmente encontra-se inoperante e graças a alta resiliência da Floresta Atlântica, esta encontrava-se quase fechada, restringindo-se a uma pequena trilha.

Após a compra de um terreno no fundo do Saco do Mamanguá um grupo de condôminos do Condomínio Laranjeiras, iniciou a reabertura desta estrada, sem comunicar aos órgãos 
responsáveis IBAMA e IEF e a própria proprietária. O grupo tinha como objetivo facilitar a chegada ao local, onde também possuíam planos de instalação de uma marina. Pessoas de fora e moradores para foram contratadas para executarem a obra, que quase foi a cabo.

Contudo houve a mobilização e ação de alguns integrantes da diretoria da Associação de Moradores e Amigos do Mamanguá-AMAM e alguns proprietários, junto ao IBAMA e aos meios de comunicação, conseguindo assim embargar a obra, no Anexo E, encontra-se a matéria de jornal publicada pela Folha de São Paulo nessa ocasião.

Neste momento cria-se um conflito, pois muitos moradores não entendem a posição da AMAM e dos órgãos ambientalistas em apoiarem a não abertura da estrada. Afinal existia a necessidade de facilitar o acesso à cidade, seja por motivos de saúde, comerciais ou simplesmente por entenderem que é um direito de ir e vir em condições mais dignas, principalmente para as pessoas mais idosas e crianças.

Por outro lado, entende-se que é legítima a preocupação das pessoas que se mobilizaram no sentido contrário, pois: i) a estrada seria privada. Como seria o controle de acesso, quanto às restrições, como na liberação deste, em um local que ainda permanece fragilmente resguardado entre as duas maiores cidades do país?; e ii) a estrada possui ligação direta com a marina.

A ameaça de instalação da marina no fundo do Saco do Mamanguá

A instalação de uma marina no fundo do Mamanguá poderia causar sérios impactos ambientais, pela proximidade do mangue, pela baixa profundidade do local, por ser um local de reprodução marinha e ainda por motivos sociais, já que a maioria das famílias ainda pratica a pesca de subsistência, deixando suas redes espalhadas por toda a extensão do mar do Mamanguá.

Porém existem moradores que são favoráveis a instalação da marina por acreditarem ser uma oportunidade de emprego. A ameaça de instalação da marina, não é recente, há muito já se ouve falar nas intenções de alguns condôminos de Laranjeiras, já que 0 acesso para seus barcos é difícil. O Prefeito quando assumiu a Prefeitura de Paraty se posicionou favorável -"desde que seja uma marina "ecológica" (!?) - , resposta dada em uma reunião na comunidade, quando indagado sobre tal fato. 
A condição de viver em uma Unidade de Conservação

Os casos da estrada e da marina esbarram antes de tudo, na condição desta região estar inserida em Unidades de Conservação e suas restrições legais. E esta condição parece ser ignorada, quando convém, por grupos poderosos aliados muitas vezes a ineficiência da aplicação das leis pelos órgãos responsáveis. E em relação à comunidade, poucos sabem, que vivem em Unidades de Conservação e o significado disto. Isto é conseqüência direta do processo de criação destas unidades na região de Paraty-RJ, que segue o mesmo padrão que ocorreu no resto do Brasil. A pouca informação e o não envolvimento da população local é uma das características comuns dos processos de implantação das Unidades de Conservação. $O$ que foi apontado por Diegues e Nogara (1994), a grande maioria das pessoas entrevistadas na época da criação da REJ, não sabiam para que servia a Reserva Ecológica e muito menos qual seria 0 impacto desta sobre suas vidas. Hoje, a discussão sobre legislação ambiental é retomada, com a ameaça real de transformação da área em Parque. A desinformação é refletida nos relatos colocados a seguir:

"Dizem que vai virar Parque, vão tirar as pessoas e cercar tudo e colocar bicho lá dentro". "E pra onde vai todo mundo?" Onde eles vão colocar as pessoas?"

Outro fato ligado às restrições da legislação ambiental, que infelizmente é ignorada, é as construções ilegais dentro da REJ e que muitos caiçaras não poderiam deixar de questionar neste momento:

"Por que as leis não valem pra gente rica?"

"O que você me diz? Vão construir um hotel, já tem gente contratada por cinco anos, com carteira assinada e vão receber 20,00 reais por dia com almoço e café da tarde... Quem é que não quer trabalhar ?"

Como já foi mencionado, as pessoas ficam divididas diante da chegada dos turistas/veranistas. Por um lado, vêem seu lugar se modificando, regras sendo impostas, porém muitas vezes a chegada do veranista significa a única perspectiva de trabalho e ganhos através de atividades diretas com a prestação de serviços ou atividades indiretas com a venda de produtos. 
O turismo provoca um choque inevitável entre mundos diferentes. E não demora para este "outro mundo" se transformar no padrão, no modelo inatingível com seus sedutores valores de consumo, de "possuir". Este "outro mundo", segundo minha ótica, chegou como um trator e muitas vezes o turismo é apresentado como a única solução possível para muitos que vivem sem perspectivas, sem a valorização do seu trabalho e muito menos do seu conhecimento sobre 0 lugar.

A educação formal na comunidade do Saco do Mamanguá

A educação formal é precária e somente as crianças têm acesso. Até o início de 2001, era oferecido o ensino fundamental dentro do sistema multiseriado em três escolas. Em janeiro de 2002, a secretaria de Educação do Município de Paraty, promove uma reforma no ensino fundamental das escolas rurais do município.

As três escolas foram concentradas em uma única escola pólo que por facilidades e coincidência, localiza-se na área da APA. A AMAM, por acreditar ser o melhor para as crianças do lugar, já que a prefeitura se responsabilizaria pelo transporte, auxiliou a prefeitura a simplesmente notificar os pais. Estes se demonstram totalmente contrários e insatisfeitos e ainda acreditaram que a Associação não os representou (mais uma vez) e associaram o fato à reclassificação da REJ em Parque, ao livro "Nosso Lugar Virou Parque" e aos trabalhos realizados pela Universidade. Fatos que enfim desencadearam uma revolta por parte dos moradores que se fecharam para o diálogo e para as possibilidades de trabalho.

Como se vê nas situações descritas é possível identificar os diferentes atores com interesses divergentes e um estado de conflito. Nas quais por vezes a AMAM acreditava estar atuando em favor da comunidade e tentava somente através de reuniões esclarecer algumas ações, porém se viu cada vez mais isolada diante dessas pressões externas.

O uso dos recursos e o envolvimento do LASTROP/USP E NUPAUB/USP com a comunidade do Saco do Mamanguá 
No início dos anos 90, o Centro de Culturas Marítimas-USP e o Departamento de Antropologia de Laval-Canadá desenvolveram pesquisas na área costeira de Paraty-RJ, dentre estas, tem-se o estudo sócio-ambiental realizado no Saco do Mamanguá, que focalizou a cultura caiçara e criação da REJ. Esse estudo sócio-ambiental que resultou na primeira edição do livro "Nosso Lugar Virou Parque" em 1994, e com isto deu início a algumas atividades que são continuadas através do NUPAUB/USP, ligadas principalmente com a mobilização da comunidade frente à pesca de arrastão, outra situação muito polêmica dentro da comunidade, que durante a época do meu trabalho de campo, essa se encontrava mais estável. Mais tarde o LASTROPESALQ/USP, também iniciou atividades, através de um projeto financiado pela Fundação Ford. Em 1998, o LASTROP ministrou pela primeira vez a disciplina "Manejo Florestal por Populações Tradicionais" no Saco do Mamanguá e a partir desta disciplina o Laboratório realizou o levantamento de informações e dados sobre o manejo florestal realizados por artesãos de caixeta, assim como a mobilização destes, para desenvolver um curso sobre "manejo dos caixetais". O curso foi oferecido em 1999 para um grupo de aproximadamente 50 artesãos. Aparentemente com resultados interessantes e estabelecimento de regras de utilização e manejo dos caixetais. Uma das propostas tiradas deste curso foi a tentativa de articulação junto ao IEF, para obtenção de uma carteirinha reconhecendo o grupo que estivesse praticando manejo. Esta seria uma forma de estimular o grupo a realizar o manejo e ao mesmo tempo protegê-los garantindo $o$ uso deste recurso.

Foi nesta oportunidade que pela primeira vez, muitas pessoas ouviram falar e discutiram sobre o manejo de recursos, organização comunitária e a legislação que rege as Unidades de Conservação. A disciplina voltou a ser ministrada por mais dois anos no Saco do Mamanguá, na qual os alunos eram divididos em grupos e juntamente com monitores abordaram este e outros temas.

Por falta de recursos financeiros e humanos o LASTROP ofereceu um acompanhamento limitado das atividades iniciadas. Tentou-se reverter esta situação com a contratação de uma técnica em 2001, para acompanhar os artesãos e o manejo. Porém, poucos artesãos haviam de fato incorporado, ou se apropriado das práticas de manejo. A articulação do LASTROP com IEF, não foi efetiva e este ainda se recusou a reconhecer o manejo dos caixetais pelos comunitários 
do Mamanguá, não autorizando a carteirinha, com o argumento que os caixetais presentes no Mamanguá eram os últimos do estado do Rio de Janeiro.

Outra situação que poucoo contribui para a valorização do grupo quanto artesãos, são os baixos preços pagos aos produtos comercializados em Paraty e em outras regiões próximas. Os lojistas pagam muito pouco pelo artesanato e vendem pelo triplo e algumas vezes não cumprem com os prazos combinados.

\section{Os fatos e as instituições envolvidas}

Todos estas situações que foram citadas acima aliadas à falta de um trabalho mais consistente e presente por parte das instituições que se propõem de alguma forma desenvolver atividades na comunidade (Universidade, IBAMA, ONGs, AMAM), culminaram na descrença por parte da comunidade. E revela também a falta de comunicação entre estas instituições, em estabelecer objetivos e estratégias comuns e a checagem crítica das já desenvolvidas a partir das parcerias.

Isto pode ser constatado em relatos de moradores alguns dias após uma reunião em que muitos manifestaram a insatisfação diante de todas as situações de pressão a que estão submetidos:

"Nada vai melhorar mesmo... o Mamanguá não vai pra frente mesmo e eu não vou mais perder meu tempo"23

"O que vai acontecer, o que você vai fazer com tudo isto que você escreve, vai para o governo?"24

Diante deste panorama algumas questões foram observadas e como a pesquisa pôde de alguma forma contribuir ao abordar estes fatos. Em alguns momentos meu papel, o que eu fazia, deixava muitas dúvidas diante da fragilidade do momento que estávamos todos vivenciando. Porém, acredito que as longas conversas com vários membros da comunidade, que por um lado me colocaram à par dos fatos e como estes eram vistos, sentidos por eles, também muitas vezes

\footnotetext{
23 Uma das moradoras do Cruzeiro, desculpando-se por não querer mais participar desta pesquisa.

24 Muitos moradores questionam sobre a(s) pesquisa(s), esta é apenas uma das falas que traduz a dúvida de muitos, especialmente de moradores com os quais não tive muito contato.
} 
foram essenciais para o esclarecimento das muitas situações, momentos de troca de informações. Conversas que também foram questionadoras e propositivas.

Participei de algumas reuniões que envolviam vários segmentos da sociedade diretamente interessados na questão da reclassificação da REJ, uma das reuniões, foi chamada pelos moradores das comunidades que estão no interior dessa Unidade de Conservação. 0 objetivo desse encontro era obter 0 máximo de informações a respeito do que estava acontecendo no andamento do processo da reclassificação, pois a maioria dos moradores não conseguia acompanhar as discussões por falta de informações e pelo excesso de termos técnicos. Foram convidados advogados, membros de algumas ONGs e pessoas da Universidade que desenvolviam trabalhos na região, trabalhamos uma tarde com lideranças das comunidades, através de pequenos grupos e utilizando um texto que seguir no Anexo $\mathrm{F}$ na tentativa de esclarecer essas pessoas sobre questões tão fundamentais em suas vidas, o direito de permanecer, estar no lugar e simplesmente ser caiçara. 


\subsection{Os Quintais Caiçaras do Saco do Mamanguá}

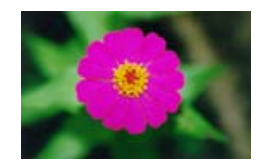

Até aqui descrevi como a comunidade do Saco do Mamanguá está inserida em um pequeno recorte histórico. Com base em alguns depoimentos colhidos durante as visitas e entrevistas, assim como em dados da bibliografia, fui percebendo como esta comunidade em um processo dinâmico reage e age diante de alguns fatos, compondo sua própria história. Com isso tentei responder a primeira pergunta norteadora do meu trabalho, com a qual propunha averiguar se os fatores sócio-ambientais externos a essa comunidade implicaram em mudanças. De certo que meu olhar se ateve a alguns pequenos trechos, também a recortes, os quais inclusive me propus também focar e que estão diretamente ligados ao uso da terra e aprofundando mais este olhar, ao sistema de produção quintal.

Assim dou seguimento a exposição dos resultados revelando o que ficou nessa pesquisa explícito em relação a percepção dos valores e funções que este sistema de produção agrega e 0 faz assumir um importante papel (mesmo que nas entrelinhas) para as famílias do Saco do Mamanguá. E se de alguma forma o quintal reflete o contexto sócio-ambiental vivenciado por esta comunidade diante de todas as informações colhidas como pano de fundo.

Obtive uma série de resultados que me permitem discutir os quintais do Mamanguá nos tempos de agora, um sistema interligado a outros sistemas de produção (roça, pesca e manejo florestal), complementando-os e ainda fazendo parte de diferentes formas, da vida cotidiana de todos os integrantes das famílias.

A complementaridade mantida entre esses sistemas de produção pode ser percebida através da dieta familiar e pelas atividades desenvolvidas pelos integrantes das famílias (dados também coletados durante a pesquisa) verificando ainda as associações mantidas com "a safra do turismo" e seus desdobramentos, como principal fator atual de "interferência" nesta comunidade.

E como se viu, com o que até então foi colocado, a chegada do turismo teve como conseqüência mais significtiva para os caiçaras, a perda de território. E de forma mais gradativa, a mudança de hábitos, e que talvez fique mais explícito de geração para geração, em que as atividades ligadas ao turismo, passam de complementares `as atividades de subsistência, para se tornarem as principais mantenedoras das famílias. 
Portanto, os principais levantamentos realizados em campo estiveram direcionados para coletar informações que levassem ao entendimento dos quintais como a identificação de categorias de uso predominantes, reconhecimento de zonas de manejo e à valorização do quintal, dentro do contexto sócio-ambiental atual da comunidade do Saco do Mamanguá, procurando avaliar essa interferência.

\subsubsection{As diferentes visões dos quintais: o êmico e o ético25}

Para todas as famílias a pesquisa sobre esse tema era muito novo e estranho, como alguém podia se deslocar (de um outro estado) para saber o que havia sido plantado em seus terreiros, ou o que as pessoas consumiam de um dia para o outro (?!). 0 que poderia significar, 0 que havia de especial naquele espaço que fazia parte do cotidiano e passava quase desapercebido, se não fosse pelas funções a serem cumpridas no local que é quase a extensão da casa?

A percepção de valores e funções se dá de diferentes formas e sua interpretação pode ser através de dois olhares: o olhar êmico, que muitas vezes não é verbalizado e sim expresso em diversas representações e o olhar de quem vai a campo e "tenta" perceber o olhar do outro, 0 olhar ético . E para reforçar a idéia de diferentes percepções me apóio no seguinte trecho em que Yi-Fu Tuan, (1980) discorre sobre esse tema:

"A percepção é uma atividade, um entender-se para o mundo. Duas pessoas não vêem a mesma realidade. Nem dois grupos sociais fazem exatamente a mesma avaliação do meio ambiente. A própria visão científica está ligada à cultura e uma possível perspectiva entre muitas" (Tuan, Yi-Fu, 1980).

Nessa pesquisa a analise ética foi enfatizada, porém me propus a estar sensível à apreensão de alguns elementos êmicos, captados através das técnicas utilizadas durante 0 trabalho de campo. Para isso através do olhar ético do outro, a tentativa de capturar a expressão

\footnotetext{
${ }^{25}$ Interpretações êmica refletem categorias cognitivas e lingüísticas de populações tradicionais, enquanto interpretações éticas são as desenvolvidas pelos pesquisadores com propósitos analíticos. É natural que essas duas categorias se obscureçam com certa freqüência, uma vez que indivíduos pertencentes a culturas distintas inevitavelmente pensam e expressam-se através de realidades cognitivas diferentes. Para que interpretações mútuas aconteçam, realidades precisam ser compartilhadas (Posey, 1992).
} 
de valores (a expressão êmica) deste sistema de produção. Entender o lugar e quem o ocupa, suas interações e interpretações e quais são as funções reconhecidas e atribuídas.

Os valores por mim reconhecidos encontram ressonância na expressão da forma dos quintais, fruto da interação de seus moradores ao longo do tempo em um determinado espaço. Procurei identificar este espaço e os marcos temporais vivenciados pela comunidade que poderiam significar mudanças nessa interação.

Através dos questionários, das conversas informais e dos resultados dos levantamentos, dos perfis e croquis, algumas categorias foram apontadas de valores e funções. $O$ papel dos quintais dentro dos sistemas de produção pode estar relacionado, por exemplo, com a experimentação, com o valor estético, com o lazer, com o local trabalho, o papel ecológico, nutricional, cultural e político (Lok, 1998a).

Entre os dezenove quintais estudados, todas as informações inicialmente propostas foram obtidas em quatorze quintais, sendo elas as seguintes: coleta botânica e classificação das plantas quanto ao uso, informações sócio-econômicas dos grupos familiares, além de plantas baixas ou croquis, e em nove quintais foram também feitos os perfis verticais. Nos outros cinco restantes, as informações ficaram incompletas, mas todas as informações obtidas nesses grupos familiares foram consideradas na análise.

Foram vários os fatores que impossibilitaram a proposta de coleta dos dados nos quintais estudados. Em um primeiro momento, com a manifestação dos responsáveis pelos grupos familiares em não quererem participar mais da pesquisa, sem razões aparentes, talvez por não se sentirem à vontade diante da minha presença ou das perguntas realizadas. Mesmo diante dos meus esforços em esclarecer meu papel, não compreenderem meu trabalho, ou por sentirem que este não tivesse de fato, alguma relevância prática em suas vidas. Outro momento que dificultou o diálogo e 0 andamento da pesquisa, foi no início de 2002, no exato momento em que estava realizando a medição das áreas dos quintais e finalizando a coleta botânica. Nessa ocasião aconteceu uma reunião em um dos povoados, que alterou os ânimos dos moradores e gerou um clima de desconfiança. Este "clima" desencadeado por uma série de fatores somados, já citados acima, acabou por afetar minhas atividades na comunidade. Não houve condições de trabalhar nos quintais, medindo as áreas. Neste momento a comunidade estava se sentindo acuada pelos boatos da criação do Parque Estadual e da ameaça de serem expulsos do lugar e com isso, o 
meu papel ficou pouco claro. Para muitos a "pesquisa" era mais um motivo para se sentirem fragilizados e visíveis pelo "mundo de fora" representado também por mim naquele momento.

\subsubsection{Um primeiro reconhecimento}

Nas primeiras visitas realizadas aos grupos familiares do Saco do Mamanguá, ao apresentar a proposta do trabalho, a primeira pergunta que fiz era como as pessoas chamavam 0 seu espaço/lugar próximo à casa. Sorridentes respondiam: "antes a gente chamava de terreiro, mas agora falam quintal, porque terreiro é coisa de macumba"26.

Outras pessoas faziam o mesmo comentário mas continuam reconhecendo este lugar como terreiro: "a gente chama mesmo de terreiro, porque quintal é menor, murado e é na cidade, aqui na roça não se tem quintal, tem terreiro e não tem cerca".

O que aos poucos se tem modificado com a presença de veranistas proprietários, é a necessidade de demarcação da propriedade. Durante as visitas que se sucederam às casas, fui observando em conversas entre as pessoas das famílias que o nome mais usado entre eles era terreiro mesmo e o termo quintal era usado com as pessoas de fora. Contudo, os dois termos são usados sem muitos preconceitos, procurei então adotar os dois termos dependendo da conversa Procurei também identificar os limites de seus quintais, pedindo para que caminhássemos até onde consideravam como suas propriedades.

Sugeri aos integrantes dos grupos familiares para que representassem seus quintais, com o intuito de uma primeira aproximação e para a partir do olhar deles, perceber como os quintais se compunham. Em um primeiro momento alguns quintais foram representados através do mapeamento das plantas em uma cartolina, a partir de um ponto de referência (a casa). Homens e mulheres se dispuseram a andar pelo quintal ou terreiro para localizarem suas plantas e depois plotá-las na cartolina com os pedaços de cartolina que foram recortadas representando as copas de diferentes tamanhos, formando assim, o mapa de seus terreiros. 0 resultado foi interessante e apresentou certa riqueza de detalhes, além da participação de vários integrantes das famílias. Um dos integrantes comentou ao mapear todas as plantas de seu quintal: "nossa

${ }^{26}$ A comunidade do Saco do Mamanguá, como descreve Diegues \& Nogara (1994) nos tempos antigos e até o último levantamento realizado por esses autores, era essencialmente católica, contudo atualmente 
nem parece que tem tanta coisa!", essa técnica foi aplicada em quatro grupos familiares. As benfeitorias também foram localizadas, assim como as principais plantas e consórcios presentes nos quintais.

Em outro momento, através de uma técnica mais livre, os quintais foram desenhados por seus moradores e estes desenhos ofereceram pouca riqueza de detalhes, quanto à composição e reconhecimento de zonas de manejo, diferente da outra técnica empregada.

Essas técnicas, em que os moradores "montaram" e desenharam seus quintais, complementaram os croquis e os perfis verticais que foram confeccionados durante o trabalho de campo e auxiliaram na identificação e caracterização das zonas de manejo que serão descritas mais adiante.

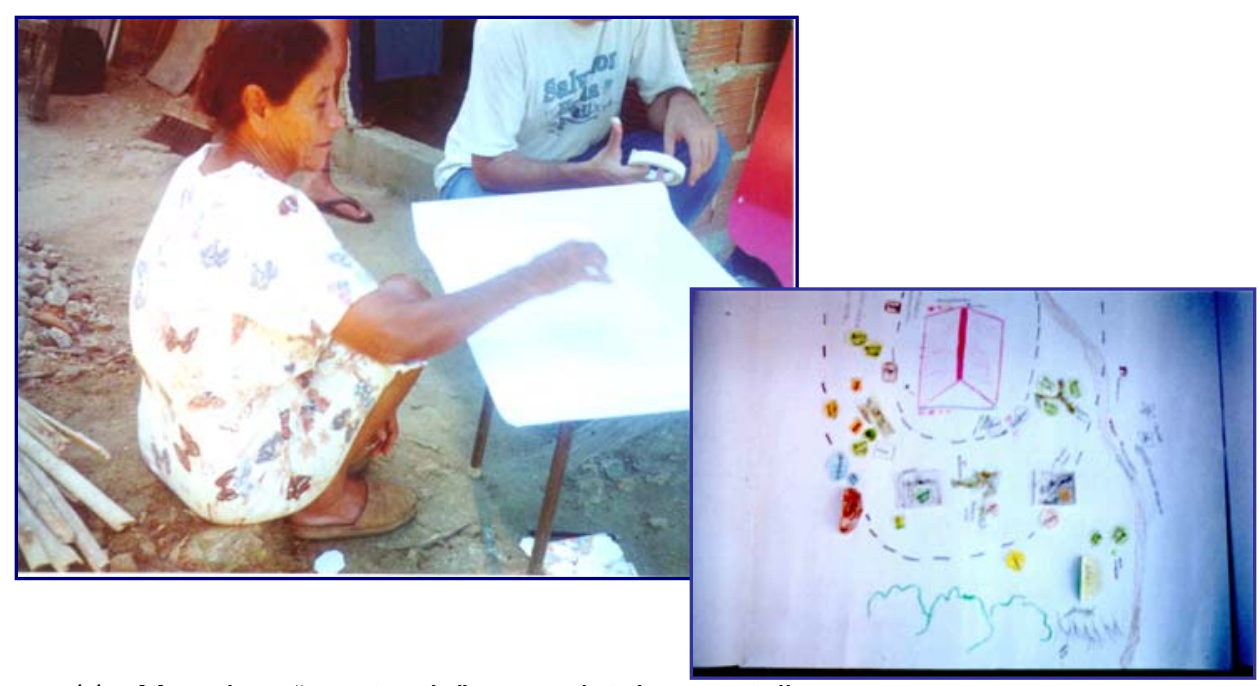

Figura 11 - Moradora "montando" seu quintal na cartolina.

entre as famílias em que realizei o estudo a maioria é evangélica, ver adiante em caracterização sócioeconômica. 


\subsection{Caracterização dos quintais estudados}

No mapa (Figura 12) apresentado abaixo é possível visualizar a comunidade do Saco do Mamanguá e a localização aproximada dos povoados. Para identificar os quintais estudados e diferenciá-los, adotei letras que correspondem as inicias dos nomes de cada povoado a qual pertencem: $\mathbf{R}=$ Regate; $\mathbf{C}=$ Curupira; $\mathbf{P P}=$ Praia do Pontal; $\mathbf{P B}=$ Praia da Bica; $\mathbf{P G}=$ Praia Grande; PR= Ponta da Romana; $\mathbf{C Z}=$ Cruzeiro; $\mathbf{B A}=$ Baixio. Em cada povoado foram estudados de dois a três quintais, com isso também adotei números que acompanham as siglas. Portanto, em toda a apresentação dos dados que se dará a seguir, os quintais estarão assim representados.

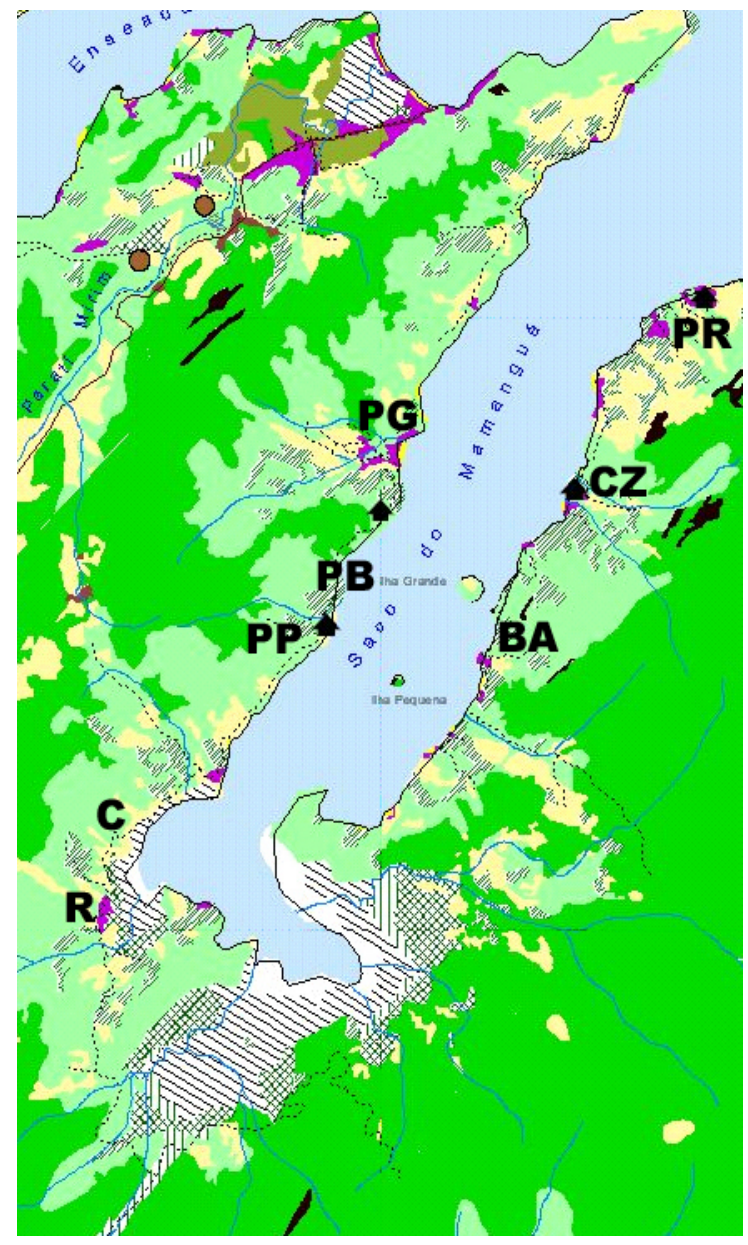

Figura 12 - Localização dos povoados no Saco do Mamanguá 
A caracterização dos quintais propicia o reconhecimento da forma como um conjunto de estruturas (horizontais e verticais) e suas funções resultantes desse conjunto, incluindo os aspectos socioeconômicos da população em questão. Os quintais podem ser caracterizados por sua área, ou por quem os maneja, pela renda obtida nesse sistema, pela diversidade de espécies e variedades encontradas, assim como pela estrutura vertical da vegetação e zonas de manejo. Esses fatores são facilmente mensuráveis, determinando a importância desses sistemas, porém, entre os valores reconhecidos, estão àqueles considerados intangíveis, ligados à estética e bemestar, recreação, local de trabalho e local onde se realizam reuniões e onde crescem os filhos, no entanto todos estão relacionados à qualidade de vida (Lok,1998a; 1998b).

Estes sistemas de produção são classificados como um tipo de sistema agroflorestal que apresentam íntima associação entre árvores e arbustos de uso múltiplo, com cultivos anuais. São complexos e variados em associações e completos em sua funcionalidade, constituídos em sua maior parte por plantas perenes, plantadas de forma aparentemente desordenada no terreno próximo à moradia. São sistemas tão diversos em quantidade e variedade, como nenhum outro sistema agroflorestal. (Nair, 1993 \& Lok, 1996, 1998a). Através da caracterização dos quintais é possível reconhecer linhas que conduzam, juntamente com as práticas de agricultura de subsistência e do conhecimento local, à proposições de novas técnicas e perspectivas para a comunidade do Saco do Mamanguá.

\subsubsection{Caracterização sócio-econômica}

Os dezenove grupos familiares representam um total de 91 pessoas, com uma média de 5 pessoas por família. Aproximadamente 45 pessoas encontram-se ativas economicamente, mesmo entre os que se aposentaram, alguns ainda exercem algum tipo de atividade extra.

Quanto à forma de apropriação da terra, praticamente todos são posseiros, apenas um grupo familiar afirma possuir o título da terra, porém seu terreno é parte de uma antiga fazenda, herança de família, com muitos herdeiros em uma situação não muito bem resolvida. $O$ nível de alfabetização é baixo, sendo que entre os responsáveis pelos grupos familiares (37 pessoas) $32,5 \%$ não lêem e escrevem, os outros $48,6 \%$ possuem o ensino primário incompleto e 18,9\% 
primário completo, o que equivale as quatro primeiras séries do ensino fundamental, e até há poonsevaçãoo tempo o ensino era multiseriado.

A religião predominante entre os grupos familiares é o protestantismo, cerca de $68 \%$ das famílias são protestantes e freqüentam as quatro igrejas espalhadas pela comunidade (Três da Assembléia de Deus e uma da Congregação Cristã do Brasil), três encontram-se na REJ e uma na APA, a mais antiga (década de 40) é próxima à escola pólo, e é freqüentada por grande parte da comunidade. 0 pastor desta igreja, que na época do trabalho de campo era recém-chegado à comunidade, foi um dos responsáveis pela conversão de algumas famílias e principalmente jovens, pois iniciou alguns grupos de música e canto, movimentando a vida pacata da comunidade atraindo assim mais pessoas para a igreja. Existe apenas uma igreja católica que se localiza no Cruzeiro, normalmente permanece fechada e o padre faz visitas pouco regulares para realizar batismos e até casamentos.

A comunidade não dispõe de energia elétrica, contudo algumas famílias possuem geradores movidos à diesel e outras utilizam-se de baterias elétricas. Mesmo assim, a geladeira já se faz presente em um número significativo de famílias (47,4\%). As geladeiras são adaptadas e funcionam com de gás de cozinha, e os butijões duram cerca de quinze dias. Esse dado é importante, pois pode ser um fator a ser considerado nas escolhas dos componentes alimentares e interferir na variedade da dieta familiar, como será discutido adiante.

As casas em sua maioria, são de alvenaria e corresponde a $58 \%$ enquanto $37 \%$ das casas são de estuque e 5\% representa a mistura de alvenaria e estuque. Em quase todos grupos notou-se a existência de outras benfeitorias nos quintais, como casa de farinha, cozinha de lenha, galinheiro e outros. Em relação ao tratamento de esgoto, a maioria das famílias que corresponde a $79 \%$ dos dezenove grupos familiares - afirma possuir banheiro e fossa séptica, e $21 \%$ disseram não possuir. O lixo é um problema para a comunidade, pois o difícil acesso faz com que o lixo que veio da cidade, como produtos industrializados destinados à alimentação, fiquem na comunidade, muitas vezes sem destino adequado. Ao caminhar pela comunidade, vêse muito lixo próximo às áreas habitadas, pois ainda não foi criado o hábito de jogar lixo de produtos industrializados em locais mais adequados. A SOS Mata Atlântica, tentou através das escolas separar o lixo e fazer um programa de reciclagem, porém algumas famílias que se dispuseram a guardar latas e vidros, nunca tiveram seu lixo reciclável recolhido. Porém, existem 
famílias que optam por enterrar e queimar o lixo, algumas, as que se locomovem com mais facilidade, acabam levando latas e vidros para a cidade.

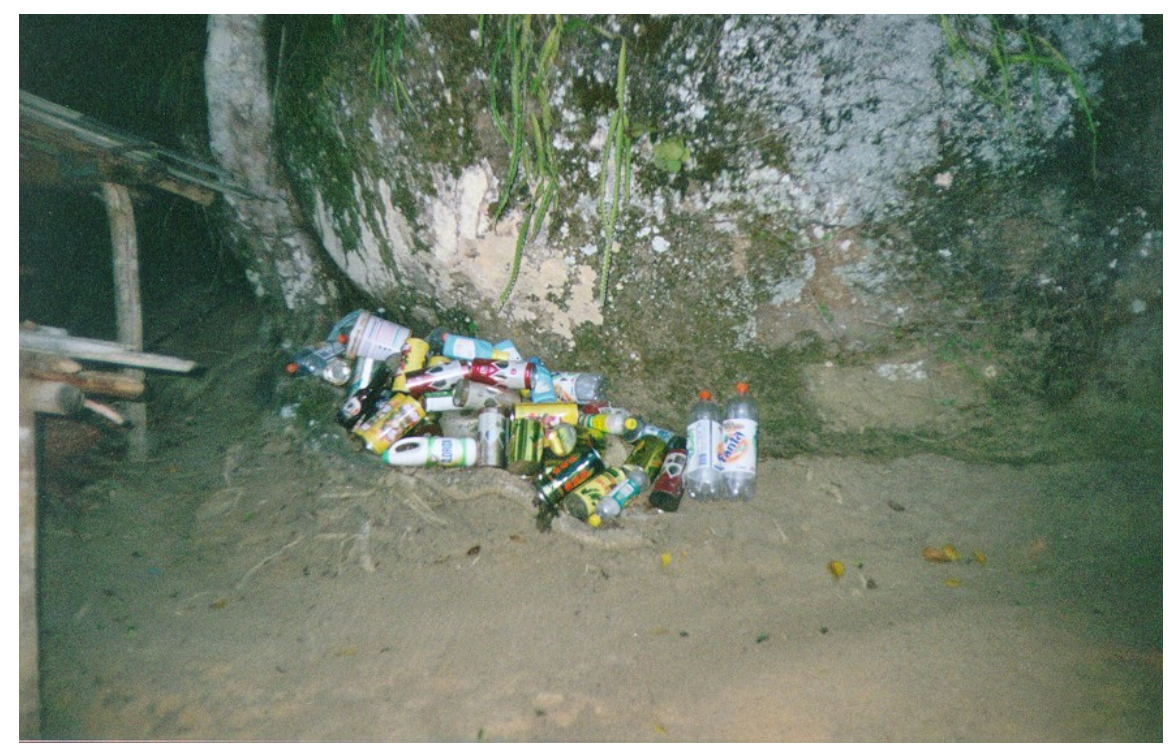

Figura 13 - Vidros e latas armazenados para serem levados para a cidade

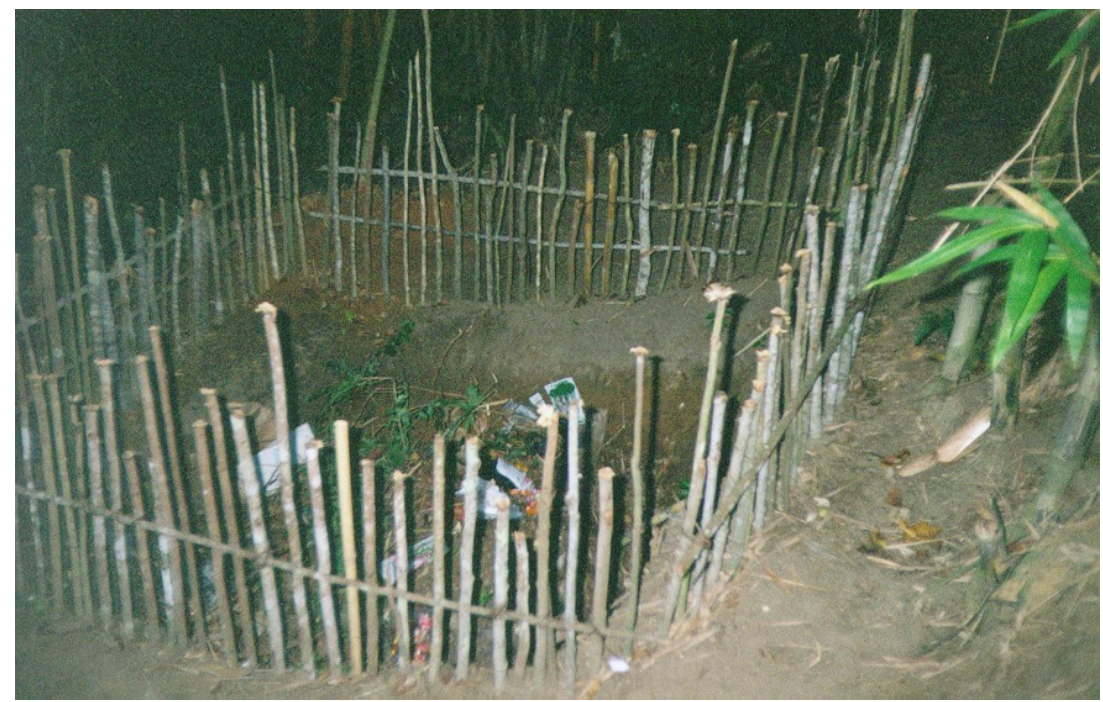

Figura 14 - Local onde o lixo é queimado 
A seguir apresento um quadro resumo (Quadro 3) com algumas características sócioeconômicas levantadas de todos os grupos familiares estudados. No qual também são observadas as benfeitorias presentes nos quintais. A presença de casa de farinha e cozinha de lenha, por exemplo, mostra ou nos remete a alguns aspectos da cultura e do cotidiano caiçara, em que o quintal funciona como a extensão da casa, e é também nesse espaço que se realiza a modificação da natureza ou sua socialização, através da transformação dos produtos. 


\begin{tabular}{|c|c|c|c|c|c|c|}
\hline GF & Localização & Apropriação & Habitação & Lixo & Tratamento Esgoto & Benfeitorias \\
\hline R1 & Regate & Posseiro & Estuque & Queima e enterra & Possui & Possui casa de farinha \\
\hline RR2 & Regate & Proprietário & Alvenaria & Queima e enterra & Possui & Casa de farinha, duas novas casas \\
\hline C1 & Curupira & Posseiro & Alvenaria & Queima e enterra & Possui & Cozinha de lenha \\
\hline C2 & Curupira & Posseiro & Alvenaria & Queima e joga na cachoeira & Não possui fossa & Não possui \\
\hline C3 & Curupira & Posseiro & Misto & Queima e enterra & Possui & Não possui \\
\hline PP1 & Praia do Pontal & Posseiro & Alvenaria & Queima e enterra & Possui & Cozinha de lenha, galinheiro, casa de farinha \\
\hline PP2 & Praia do Pontal & Posseiro & Estuque & Queima e joga na cachoeira & Possui & Cozinha de lenha, galinheiro, casa p/a tur. \\
\hline PP3 & Praia do Pontal & Posseiro & Alvenaria & Queima e enterra & Possui & Não possui \\
\hline PB1 & Praia da Bica & Posseiro & Alvenaria & Queima e leva para a cidade & Possui & Cozinha de lenha, galinheiro \\
\hline PG1 & Praia Grande & Posseiro & Estuque & Queima e enterra & Possui & Casa de farinha, galinheiro, cozinha de lenha \\
\hline PG2 & Praia Grande & Posseiro & Estuque & Queima e leva para a cidade & Possui & Cozinha de lenha, casa de farinha \\
\hline PG3 & Praia Grande & Posseiro & Alvenaria & Queima e enterra & Possui & Casa de farinha \\
\hline PR1 & Ponta da Romana & Posseiro & Alvenaria & Queima e leva para a cidade & Possui & Casa de farinha, cozinha de lenha \\
\hline PR2 & Ponta da Romana & Posseiro & Alvenaria & Queima e leva para a cidade & Possui & Galinheiro \\
\hline CZ1 & Cruzeiro & Posseiro & Estuque & Queima e enterra & Possui & Não possui \\
\hline CZ2 & Cruzeiro & Posseiro & Estuque & Queima e joga na cachoeira & Não possui fossa & Galinheiro, casa de farinha \\
\hline BA1 & Baixio & Posseiro & Estuque & Queima e joga na cachoeira & Não possui fossa & Não possui \\
\hline BA2 & Baixio & Posseiro & Alvenaria & Queima e enterra & Possui & Casa de farinha, cozinha de lenha \\
\hline BA3 & Baixio de dentro & Posseiro & Alvenaria & Queima e enterra & Não possui fossa & Não possui \\
\hline
\end{tabular}

Quadro 3 - Algumas característica sócio-econômicas dos grupos familiares estudados no Saco do Mamanguá 
- As atividades desenvolvidas atualmente pelos grupos familiares e a ligação com o turismo.

A maioria das pessoas entrevistada está envolvidas em ocupações múltiplas, contudo, considerei atividades principais e secundárias que se alternam entre si. Dentre essas estão aquelas que são praticadas no âmbito da subsistência e tidas como tradicionais (pesca de subsistência, coleta e preparo de pescados, (sapinhanguá - marisco, siri, ostra), roça. E aquelas atividades que agora atendem a uma nova demanda e representam novas possibilidades de obter recursos financeiros, como venda de artesanato, através de serviços de caseiro, jardineiro e fretes para turistas). Dividi essas atividades segundo a relação que é mantida com o turismo, em: (i) "relação direta", é aquelas que apresentam um vínculo empregatício, com salário ou remuneração por pequenos serviços prestados e (ii) relação indireta", seria aquelas em que a renda é obtida através da venda de produtos aos turistas, tanto na cidade de Paraty ou em outras cidades turísticas, como na própria comunidade para os veranistas. A seguir apresento o resumo das principais atividades desenvolvidas pelos responsáveis dos grupos familiares por povoado e a relação destas com o turismo (Quadro 4).

\begin{tabular}{|c|c|c|c|c|c|}
\hline \multirow{2}{*}{$\begin{array}{l}\text { Principal Atividade } \\
\text { Desenvolvida }\end{array}$} & \multicolumn{2}{|c|}{$\begin{array}{ll}\text { Divisão } & \text { por } \\
\text { Gênero } & \end{array}$} & \multicolumn{2}{|c|}{$\begin{array}{l}\text { Relação com } 0 \\
\text { Turismo }\end{array}$} & \multirow{2}{*}{ 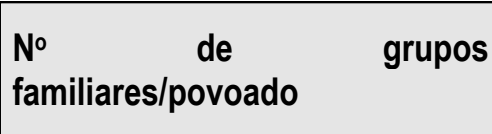 } \\
\hline & 9 & $\hat{0}$ & Direta & Indireta & \\
\hline Artesanato & $\mathbf{X}$ & $\mathrm{X}$ & & & $\begin{array}{l}\text { 2/Regate; 1/Praia do Pontal e } \\
\text { 3/Baixio. }\end{array}$ \\
\hline $\begin{array}{l}\text { Siri - Marisco - } \\
\text { Camarão }\end{array}$ & $\mathbf{X}$ & $\mathrm{X}$ & & $X$ & $\begin{array}{l}\text { 2/Curupira e 1/Praia do Pontal; } \\
\text { 1/Praia da Bica*. }\end{array}$ \\
\hline Pesca Artesanal & & $\bar{X}$ & & $\bar{X}$ & 1/Curupira; 1/Baixio. \\
\hline Construção & & $X$ & $X$ & & $\begin{array}{l}\text { 2/Regate; 1/Curupira; 2/Pontal; } \\
\text { 1/Praia da Bica; 3/Praia Grande; } \\
\text { 3/Baixio. }\end{array}$ \\
\hline $\begin{array}{l}\text { Caseiros (casa e } \\
\text { jardinagem) }\end{array}$ & $X$ & $\mathrm{X}$ & $X$ & & $\begin{array}{l}\text { 1/Curupira; 2/Pontal; 1/Praia da } \\
\text { Bica; } 2 \text { Praia Grande;1/Baixio. }\end{array}$ \\
\hline Transporte/ lancha & & $\mathrm{X}$ & $\mathbf{X}$ & & $\begin{array}{l}\text { 1/Pontal; 1/Baixio; 1/Ponta da } \\
\text { Romana; 1/Praia da Bica. }\end{array}$ \\
\hline Outras Atividades & $X$ & $X$ & & & $\begin{array}{l}\text { Roça- 2/Praia Grande; Pesca - 1 } \\
\text { Cruzeiro; Merendeira 1/Praia } \\
\text { Grande } q\end{array}$ \\
\hline Aposentados (as) & $\mathrm{X}$ & $\mathrm{X}$ & & & $\begin{array}{l}\text { 1/Regate; 1/Curupira, } 1 \text { Pontal; } \\
\text { 1/Praia Grande; } 1 \text { Cruzeiro; } 1 \\
\text { Ponta da Romana. }\end{array}$ \\
\hline
\end{tabular}

Quadro 4 - As principais atividades desenvolvidas pelos grupos familiares e a relação com o turismo 
Dentro desse espectro de múltiplas funções desempenhadas pelos integrantes das famílias, são reconhecidas oito categorias de atividades: ligadas aos recursos pesqueiros, às roças, ao artesanato, às construções, transporte, jardinagem e de caseiros. De acordo com as observações feitas em campo realizo a seguir uma breve descrição de algumas dessas atividades e como as funções específicas encontram-se divididas por gênero.

As atividades ligadas aos produtos pesqueiros são divididas entre coleta/pesca, limpeza e retirada da carne (no caso de siri, mariscos). Na coleta tanto a mulher (com o auxílio das crianças), como os homens participam destas atividades, já a pesca e a venda dos produtos, geralmente o homem é quem as executa.

No caso das roças, as atividades diárias ligadas a este sistema são praticadas essencialmente pelos mais idosos, contando com a ajuda de jovens e das mulheres, especialmente quando se dá o preparo da farinha de mandioca. Alguns dos produtos, após suprir a necessidade da família, em época de veraneio, são vendidos aos turistas, especialmente aqueles que se mantém algum tipo de relação, como por exemplo, onde algum parente trabalha.

No artesanato, as funções também se dividem em coleta (caixeta- Tabebuia cassinoides, cipó e a palha do coco preto, por exemplo ), confecção do produto e venda. A coleta da madeira no caixetal e a venda cabem ao homem, enquanto que a confecção ambos a executam, com diferentes tipos de encomendas, ou ainda a mulher apenas auxilia o marido no trabalho de confecção e na pintura das peças, quando essas são pintadas. Os homens que têm como principal atividade 0 artesanato, no inverno quando a venda de artesanato é pouca, dedicam-se também a construção outras atividades.

As funções de caseiros são desenvolvidas geralmente pelo casal, mas também com funções específicas. As mulheres trabalham com serviços da casa (do veranista) e do quintal e os homens estão mais ligados à manutenção (serviços gerais) da casa, embarcações, pequenos reparos e jardinagem.

As atividades de pesca de cerco ou rede, coleta de mariscos, assim como o plantio e os cuidados com as roças, quando o grupo familiar ainda às possui, tornam-se secundárias, durante a época de veraneio, são complementares às atividades principais, que em sua maioria possuem vínculos com o turismo (diretos ou indiretos). As mulheres além de participar de diferentes tarefas junto ao marido, ainda desempenham as atividades ligadas aos cuidados com a casa e com os 
filhos. Tratam dos animais domésticos e quando possuem hortas, também são elas as principais responsáveis, assim como com os quintais, sendo elas as principais responsáveis, os quais vou ainda descrever melhor mais adiante, quando tratar especificamente desse tema.

Quanto a aposentadoria, alguns entrevistados a conquistaram, contudo a maioria das mulheres relatam a dificuldade em consegui-la, mesmo tendo trabalhado a vida toda na roça, como registrado em alguns depoimentos. E quando o marido já é aposentado fica ainda mais difícil de consegui-la.

Das 45 pessoas que desempenham atividades econômicas, 56\% têm como principais atividades àquelas ligadas diretamente ao turismo (caseiros e construção). Enquanto 29\% desenvolvem as atividades ligadas indiretamente ao turismo, principalmente 0 artesanato, que envolve tanto homens quanto mulheres proporcionalmente. Outras atividades como roça, emprego público - merendeira escolar - e pesca embarcada correspondem a $13 \%$ das atividades principais da população ativa dos grupos familiares estudados.

Quando perguntei a respeito das atividades que as pessoas do lugar estão atualmente envolvidas a um dos entrevistados, que deu início ao povoado da Ponta da Romana- REJ, respondeu que os mais velhos já estão aposentados e os mais novos trabalham como caseiros ou em construções, relato que antecipou a análise quantitativa aqui apresentada.

- As funções desempenhadas nos quintais

Entre as múltiplas funções desempenhadas pelos responsáveis dos grupos familiares, há também àquelas relacionadas aos quintais, no qual também são percebidas atividades distintas entre mulheres e homens, inclusive o território também se encontra dividido coincidindo com os diferentes estratos. A presença predominante do estrato herbáceo, indica entre outras coisas, que o quintal é um espaço essencialmente feminino, e talvez sua expressão maior resida no fato de que praticamente todos os quintais, como será visto mais adiante na caracterização etnoecológica, possuam grande número de ornamentais. E ainda junto a estas tem-se as plantas para remédio e as condimentares, que se localizam próximas às casas e cozinhas, sendo as mulheres as principais responsáveis por essas plantas. Já os homens cuidam das plantas de 
futuro ${ }^{27}$, como por exemplo o coqueiro e a bananeira, a eles são destinados atividades mais pesadas ligadas principalmente ao estrato arbóreo, como as fruteiras, realizando podas e colheitas e até a capina, mas esta pode ser também dividida com as mulheres. Já às mulheres, cabem também os cuidados com a criação de pequenos animais (especialmente galinhas), hortas (quando possuem) e a limpeza semanal dos terreiros, varrendo as folhas das proximidades da casa, com vassouras feitas com uma planta denominada "vassoura" (Bacharis sp). Essa prática é considerada importante para que a família não corra o risco com animais peçonhentos e mantém as proximidades da casa limpas. Portanto, o que observei é que apesar das tarefas dos quintais encontrarem-se de alguma forma divididas entre homens e mulheres, a maioria das tarefas é executada pela mulher, também por passar mais tempo na casa. A não ser quando têm o artesanato como atividade principal e esta é executada no quintal. Ao responderem quanto tempo despendiam as funções dos quintais, poucos consideraram as atividades diárias, por exemplo com a criação, ou em épocas de seca, com a irrigação, e até podas que na realidade são pouco freqüentes. Parecem ter considerado mais a limpeza semanal o que corresponde de duas a quatro horas dependendo do tamanho do quintal, ou quantas pessoas auxiliam nessa atividade.

\subsubsection{Caracterização etnoecológica}

- Área, diversidade e idade dos quintais caiçaras e seus responsáveis do Saco do Mamanguá

A diversidade de espécies presentes nos quintais está diretamente ligada a maior oferta de produtos e em diferentes épocas do ano, que pode ou não estar relacionada com a área disponível e/ou a idade do quintal. Abaixo apresento os dados obtidos e a discussão relacionada ao número de espécies por quintal, com suas áreas e idades correspondentes (Quadro 5).

\footnotetext{
27 Planta de futuro é aquela que oferecerá algum ganho, através da comercialização de seus frutos/produtos.
} 


\begin{tabular}{|c|c|c|c|c|c|}
\hline \multirow{2}{*}{ GF } & \multirow{2}{*}{ Área $\left(m^{2}\right)$} & \multirow{2}{*}{$\begin{array}{c}\mathrm{N}^{0} \text { de Espécies } \\
\text { /Quintal }\end{array}$} & \multirow{2}{*}{$\begin{array}{c}\text { Idade dos } \\
\text { Quintais- Anos }\end{array}$} & \multicolumn{2}{|c|}{ Idade Resp. } \\
\hline & & & & $\mathrm{F}$ & $M$ \\
\hline R1 & 1475 & 79 & 12 & 44 & 33 \\
\hline $\mathrm{R} 2$ & 5752 & 101 & $>70$ & 71 & 51 \\
\hline C1 & 1390 & 106 & 17 & 45 & 36 \\
\hline $\mathrm{C} 2$ & $2294^{*}$ & 72 & $>50$ & 22 & 31 \\
\hline C3 & 694 & 55 & 01 & --- & 77 \\
\hline PP1 & 1592 & 70 & $>16$ & 50 & 45 \\
\hline PP2 & 802 & 93 & $>19$ & 60 & 69 \\
\hline PP3 & 1630 & 63 & 19 & 49 & 39 \\
\hline PB1 & 1702 & 90 & $>20$ & 67 & 67 \\
\hline PG1 & 1969 & 91 & $>30$ & 70 & 55 \\
\hline PG2 & 920 & 73 & 20 & 76 & 68 \\
\hline PG3 & 855 & 71 & $>18$ & 50 & 42 \\
\hline PR1 & $2297^{*}$ & 48 & $>40$ & 71 & 70 \\
\hline PR2 & 1362 & 50 & 26 & 49 & 47 \\
\hline CZ1 & Peq. & 23 & 30 & 53 & 42 \\
\hline CZ2 & Med. & 27 & $>50$ & 82 & 70 \\
\hline BA1 & Peq. & 38 & 05 & 29 & 24 \\
\hline BA2 & Med. & 45 & 36 & 44 & 30 \\
\hline BA3 & Med. & 16 & 12 & 44 & 42 \\
\hline
\end{tabular}

Quadro 5 - Dados referentes a riqueza de espécies, área e idade de formação dos quintais e dos responsáveis dos dezenove quintais estudados

Inicio a caracterização etnoecológica apresentando os dados obtidos referentes à diversidade de espécies presentes nos quintais, comparando-os a outros estudos semelhantes realizados em outros lugares. Nos dezenove quintais encontrou-se um total de 347 espécies e 28 
variedades. 0 número variou de 16 a 106 espécies por quintal e teve como média 64 espécies. As principais famílias botânicas presentes no levantamento foram as seguintes: Asteraceae, Euphorbaceae, Solanaceae, Verbenaceae, Myrtaceae, Rutaceae, Lamiaceae, Araceae, Malvaceae, Mimosaceae, Arecaceae, Melastomataceae e Moraceae. Em anexo (Anexo G) encontra-se a listagem completa com nome popular, nome científico, família, hábito e uso das plantas que foram coletadas nos dezenove quintais durante o trabalho de campo.

Estudos realizados na América Central com quintais na Costa Rica, Honduras e Nicarágua, revelam números muito próximos aos que foram obtidos nos quintais do Mamanguá em meio à Floresta Atlântica. A média de espécies encontradas em amostras que giram em torno de 10 a 20 quintais estudados nesses países é de 249 espécies (Lok, 1998a). A média do número de espécies perenes para a Amazônia é em torno de 60 por quintal. No interior de São Paulo, a média foi de 61 plantas frutiferas em 13 quintais, com uma variação de 16 a 176 plantas, (Ambrósio; Peres; Salgado, 1996). Já o que se encontra nos quintais dos países tropicais asiáticos, especialmente em Java, o número de espécies por quintal eleva-se para 180 em áreas de aproximadamente $0,1 \mathrm{ha}$, com a presença de muitas plantas perenes de uso múltiplo, distribuídas em quatro estratos, fato este que se deve à alta concentração demográfica da ilha. (Viana; Dubois; Anderson, 1996).

As áreas em geral obtidas nesses estudos são maiores do que as que foram levantadas nos quintais do Mamanguá e apresentam a média de 0,3 ha nos quintais estudados na Nicarágua, 0,5 ha na Costa Rica e de 0,2 a 0,9 ha nos quintais de Honduras, os quintais estudados na Amazônia não ultrapassam a 1 ha. Enquanto que a média da área encontrada em 14 quintais no Saco do Mamanguá foi de $1402 \mathrm{~m}^{2}$ ou 0,14 ha.

Sendo que dos quatorze grupos que tiveram suas áreas medidas, dois grupos (Ponta da Romana-PR1 e Regate - R2) incluem pequenos plantios um, mais caracterizados como roçado e o outro grupo com café sombreado em áreas adjacente aos de quintais. 0 grupo familiar PR1 apresenta plantio de mandioca consorciado com bananas e o outro grupo do Regate - R2, apresenta o plantio de café sombreado com fruteiras (pitanga, jabuticaba) e nativas de grande porte (por exemplo, o Garapubu- Schizolobium parahyba). Dois motivos fizeram com que considerasse esses plantios: (i) limites não delimitados, e (ii) a presença de muitas fruteiras e estes encontram-se relativamente próximos às moradias. 
Os últimos cinco grupos familiares não apresentaram suas áreas medidas devido aos problemas que ocorreram durante o trabalho de campo já relatados, porém com base nos demais quintais que foram visitados, os classifiquei de pequenos a grandes.

Ao se tratar da área dos quintais nessa comunidade caiçara, é preciso fazer uma importante observação relacionada à dinâmica interna de distribuição e ocupação dos espaços pelas famílias na comunidade e que de alguma forma atualmente também reflete um movimento externo, com a venda das posses e a chegada dos veranistas. Trata-se da divisão do espaço e conseqüente perda de área de quintal e cultivo da pequena posse, principalmente para os filhos que se casam e em segundo, com outros parentes. Entre os dezenove grupos familiares visitados, quatro encontra-se nessa situação ( $R 2$ atualmente com três casas, duas em construção; C2 com quatro casas, duas recentemente construídas e uma em construção; BA1 com duas casas e BA3 com duas casas). No Grupo Familiar do Curupira - C2, desenvolvi o trabalho com apenas uma família, casal jovem, filhos pequenos e o espaço que corresponde a esse grupo é pequeno, e recentemente ocupado, o local onde foi construída a casa, era o local de cultivo de batata doce. Contudo, considerei toda a área, pois todos se utilizam de seus benefícios, além de ser um dos quintais antigos presentes na pesquisa.

Outros três grupos, do total estudado, (PP3, PR1 e CZ2) enquadram-se também na situação acima colocada, porém são famílias axtensas e numerosas e essa divisão já ocorreu inúmeras vezes abrigando na mesma posse, diferentes gerações, filhos, netos e bisnetos. Em todos os casos, é observado o uso do espaço por todas as famílias.

Outra situação mais recente entre os quintais estudados, é a construção de casas de aluguel para turistas, que foi observada em dois grupos familiares (PP2 e PB1), nesse caso, esse espaço passou a ser utilizadode forma diferenciada para o aporte econômico das famílias.

O aumento populacional e a diminuição do espaço para plantios, reflete-se de forma diferente em comparação com o que foi verificado em Java. A pressão demográfica juntamente com a demanda urbana por produtos hortifrutigranjeiros e a diminuição de território para plantios, teve como comseqüência o aumento da diversidade nos quintais. Além de tornarem-se mais diversos, modificaram-se quanto ao seu significado maior, que passa a ser o aporte econômico, com a venda de produtos para o mercado, em detrimento da complementação alimentar para família, como a que é observada nos quintais do Mamanguá e na maioria dos quintais da 
América Latina. Situações que refletem claramente a importância do meio social (econômico e cultural) como determinante das práticas de manejo do espaço e suas mudanças.

Em cada caso, há um fator ou mais fatores que desencadeiam mudanças na utilização e manejo dos espaços. 0 que observei no Mamanguá como um dos fatores influentes nessa situação, foi a venda das posses, o que significou perda efetiva do território, afetando com isso a migração interna, restringindo a ocupação de novos espaços. Na maioria dos casos, os veranistas ocuparam a área costeira com a conseqüente concentração de casas de caiçaras morro acima. Esse fato é bem observado no povoado da Ponta da Romana, como já descrito no item em que discorro sobre a influência do turismo, e que significou a redução de quintais e áreas de plantios, ou até mesmo a perda total destas. Contudo, ao escolher os grupos familiares desse povoado, considerei aqueles que ainda possuíam área de plantio, já que meu objetivo era caracterizar os quintais caiçaras e a relação destes com a dieta familiar.

Os quintais estudados apresentam uma grande variação em relação às suas idades de formação: variando de 01 ano à mais de 70 anos. 0 que pude perceber é que não existe necessariamente relação direta entre idade e riqueza de espécies. Vou pegar como exemplo quatro quintais. Ao comparar os quintais com idades aproximadas (C3 e BA1; PP1 e BA2) estes apresentam números de espécies bem diferenciados. Esta comparação reforça outra característica dos quintais: a subjetividade quanto as decisões de manejo e composição desse espaço por seus responsáveis.

- A composição dos quintais

O levantamento etnobotânico averiguou como são constituídos identificando as espécies presentes nos quintais agroflorestais e quais categorias de uso estão presentes nesse espaço.

Entre os diferentes usos das plantas por essas populações considerei algumas categorias de uso que me foram apontadas durante as entrevistas e coleta botânica.

As plantas coletadas foram classificadas em cinco principais categorias de uso, no entanto existem espécies que se enquadram em mais de uma categoria, para isto as subdividi como será apresentada a seguir: (i) Alimentação, subdividida em: Alimentação e Medicinal, Alimentação e ornamental, Alimentação e outros; (ii) Condimentos; (iii) Medicinal, subdividida em: Medicinal e condimentar, Medicinal e ornamental, Medicinal e outros; (iv) Ornamental, e 
Ornamental e outros e (v) Outros. Essa última categoria engloba por exemplo, uso da madeira para construções, lenha, resinas, corantes e etc.

O levantamento realizado nos dezenove quintais caiçaras do Mamanguá indica a predominância de ornamentais (42,1\%), como já citado acima, esse dado reflete espaços essencialmente femininos, já que os cuidados com essas plantas cabem, em sua maioria, às mulheres. Outro ponto revelado com esse dado, está relacionado ao que se pode chamar de valor intangível dos quintais, ligado à estética e ao bem-estar das famílias. Em segundo tem-se na alimentação, com $27,3 \%$, outra importante categoria de uso destes espaços pelos grupos familiares, confirmando o potencial dos quintais para a complementação da dieta familiar, já bem discutido anteriormente através da bibliografia pertinente. As plantas destinadas para 0 uso medicinal participam com $11,9 \%$ e 3,2\%, as plantas condimentares. Nos estudos relacionados às plantas medicinais, a análise quantitativa tenta aferir através da freqüência de certas plantas 0 grau de importância e a consistência do uso destas. As plantas medicinais mais freqüentes nos quintais entre as 43 citadas são: saiãozinho, (Kalanchoe sp), capim limão, (Cymbopogon citratus), hortelã de galinha (Plectranthus sp), boldo arbusto (Plectranthus cf barbatus), terramicina (Pfaffia sp), embaúba branca (Cecropia sp), arruda (Ruta graveolenses), hortelã (Plectranthus sp), novalgina (Pfaffia cf glomerata), babosa (Aloe vera).

A categoria "outros usos" contribuíram com $15,5 \%$ do total de plantas presentes nos dezenove quintais, sendo que grande parte dessa categoria é constituída por espécies nativas e compõem em sua grande maioria o estrato arbóreo. A seguir apresento a Tabela 1 e o respectivo gráfico (Figura 15) com os valores correspondentes para cada categoria de uso, para os dezenove quintais estudados. 
Tabela 1. Porcentagem das espécies dos quintais que compõem as diferentes categorias de uso

\begin{tabular}{|c|c|c|}
\hline Principal Categoria de Uso & $\begin{array}{ll}\text { Subdivisões } & \text { das } \\
\text { Categoriasde uso }\end{array}$ & Porcentagem \% \\
\hline \multirow{4}{*}{ Alimentação } & Alimentação & 19,5 \\
\hline & Alimentação e medicinal & 5,9 \\
\hline & Alimentação e ornamental & 0,3 \\
\hline & Alimentação e outros & 1,6 \\
\hline Subtotal & & 27,3 \\
\hline Condimentos & Condimentos & 3,2 \\
\hline Subtotal & & 3,2 \\
\hline \multirow{4}{*}{ Medicinal } & Medicinal & 10,1 \\
\hline & Medicinal e ornamental & 0,8 \\
\hline & Medicinal e outros & 0,5 \\
\hline & Medicinal e condimentar & 0,5 \\
\hline Subtotal & & 11,9 \\
\hline \multirow{2}{*}{ Ornamental } & Ornamental & 39,2 \\
\hline & Ornamental e outros & 2,9 \\
\hline Subtotal & & 42,1 \\
\hline Outros & Outros & 15,5 \\
\hline Subtotal & & 15,5 \\
\hline Total & & 100 \\
\hline
\end{tabular}




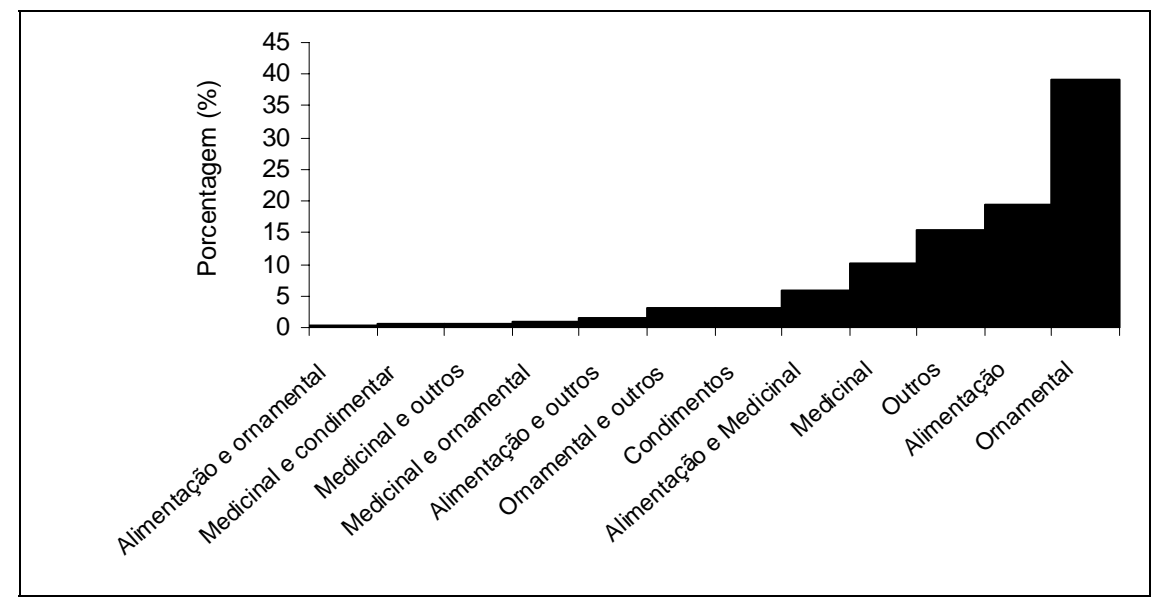

Figura 15 - Gráfico representando as diferentes categorias de uso dos quintais

A seguir na Tabela 2, apresento os resultados obtidos em todos os quintais, nesse caso apresentei apenas as principais categorias de uso. Quando determinada espécie era classificada em mais que uma categoria, considerei a principal. Nesta tabela constam as porcentagens das espécies agrupadas nessas categorias de uso (alimentação, medicinal, condimentar, ornamental e outros) coletadas por quintal.

Tabela 2. Porcentagem das espécies que compõem as diferentes categorias de uso por quintal

\begin{tabular}{cccccc}
\hline \multicolumn{5}{c}{ Porcentagem de espécies- (\%) para cada categoria de uso } \\
GF & Alimentação & Medicinal & Condimento & Ornamental & Outros Usos \\
\hline & 36,9 & 23,9 & 6,0 & 25,0 & 8,3 \\
R1 & 41,7 & 12,9 & 5,9 & 28,7 & 9,9 \\
R2 & 30,0 & 10,0 & 3,6 & 48,2 & 8,2 \\
C1 & 38,7 & 5,3 & 5,3 & 42,7 & 8,0 \\
C2 & 33,4 & 7,4 & 3,7 & 46,3 & 9,3 \\
C3 & 43,1 & 6,9 & 5,6 & 38,9 & 5,6 \\
PP1 & 30,6 & 10,2 & 5,1 & 48,0 & 6,1 \\
PP2 & 57,6 & 10,6 & 1,5 & 47,0 & 3,0 \\
PP3 & & &
\end{tabular}


Tabela 2. Porcentagem das espécies que compõem as diferentes categorias de uso por quintal

\begin{tabular}{lccccc}
\hline \multicolumn{5}{c}{ Porcentagem de espécies- (\%) para cada categoria de uso } \\
GF & Alimentação & Medicinal & Condimento & Ornamental & Outros Usos \\
\hline PB1 & 31,6 & 8,1 & 4,1 & 34,7 & 21,4 \\
PG1 & 19,1 & 8,5 & 4,3 & 58,5 & 9,6 \\
PG2 & 22,3 & 10,5 & 5,3 & 44,7 & 17,1 \\
PG3 & 23,6 & 13,9 & 1,4 & 58,3 & 2,8 \\
PR1 & 37,4 & 2,1 & 4,2 & 41,7 & 16,7 \\
PR2 & 43,1 & 4,0 & 2,0 & 47,1 & 3,9 \\
CZ1 & 60,0 & 28,0 & 12,0 & 0,0 & 0,0 \\
CZ2 & 73,0 & 7,6 & 11,5 & 0,0 & 0,0 \\
BA1 & 25,0 & 18,7 & 0,0 & 53,1 & 3,1 \\
BA2 & 51,3 & 14,2 & 2,4 & 19,5 & 9,8 \\
BA3 & 50,0 & 31,3 & 6,3 & 12,5 & 0,0 \\
\hline
\end{tabular}

Para averiguar se as diferenças existentes entre os quintais, quanto a categoria de uso eram significativas entre os grupos estudados, realizei uma análise não-paramétrica (KomogorovSmirnoff, do programa Statitsca). Para isto, dividi os quintais primeiramente em dois grupos, os pertencentes à APA e os que estão na REJ, analisei todas as variáveis, sendo que as diferenças existentes não foram significativas, o mesmo ocorreu para a análise feita, ao dividir novamente os quintais em dois outros grupos, um correspondente aos quintais do fundo do Saco do Mamanguá e o outro àqueles que se encontram na entrada, onde a presença do turismo é mais significativa. Porém os valores encontrados identificam os principais potenciais de uso ou funções determinadas pela composição de cada quintal, assim como oferece pistas em relação às decisões por parte de quem os maneja, que determinam os cultivos que permanecem ou a retirada de espécies.

Todo o material botânico coletado nos dezenove quintais também foi classificado quanto ao hábito das plantas e desta forma a presença dos principais estratos (alto, médio e baixo) foi identificada e segue representada na Tabela 3 com o gráfico correspondente (Figura 16). Os estratos foram divididos em: (i) arbóreas nativas e cultivadas e que somadas representam $31,8 \%$ 
do total de plantas coletadas que compõem os estratos mais altos, (ii) arbustivas nativas e cultivadas que também somadas correspondem à 16,8\%; e (iii) as herbáceas que representam a maior porcentagem de plantas nos quintais com 48\%, ainda tem-se as epifitas e cipós ou lianas, que somadas representam $3,4 \%$ do total levantado nos dezenove quintais.

Tabela 3. Porcentagem das espécies dos quintais estudados que compõem os diferentes estratos verticais

\begin{tabular}{lll}
\hline Estratos & Subdivisão dos estratos & Porcentagem \\
\hline Arbóreo & Nativas & 20,1 \\
& Cultivadas & 11,7 \\
Subtotal & & 31,8 \\
Arbustivo & Nativas & 1,6 \\
Subtotal & Cultivadas & 15,2 \\
Herbáceo & & 16,8 \\
Epífitas & Herbáceo & 48,0 \\
Cipó & Epífitas & 1,3 \\
Total & Cipó & 2,1 \\
\hline
\end{tabular}

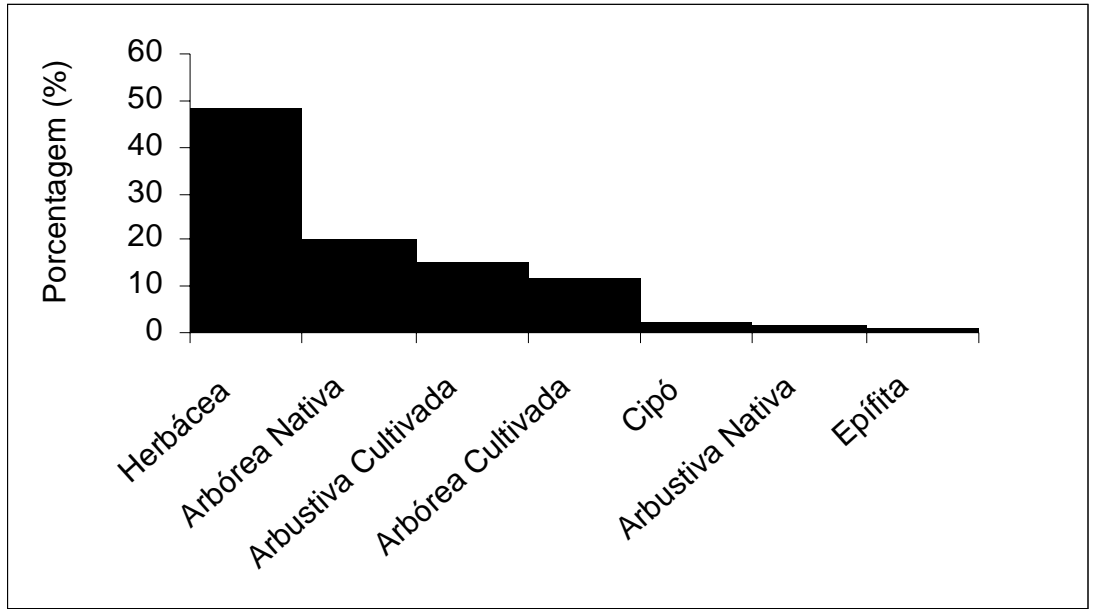

Figura 16 - Gráfico representando as porcentagens dos diferentes estratos presentes nos quintais estudados no Mamanguá 
A Tabela 4 refere-se à estrutura vertical de cada quintal, na qual são apresentadas as porcentagens de espécies correspondentes aos estratos verificais encontrados.

Tabela 4. Porcentagem das espécies divididas entre os diferentes estratos por quintal

\begin{tabular}{|c|c|c|c|c|c|c|c|}
\hline \multirow{2}{*}{ GF } & \multicolumn{2}{|c|}{ Arbórea (\%) } & \multicolumn{2}{|c|}{ Arbustiva (\%) } & \multirow{2}{*}{$\begin{array}{l}\text { Herbáceas } \\
(\%)\end{array}$} & \multirow{2}{*}{$\begin{array}{l}\text { Lianas } \\
(\%)\end{array}$} & \multirow{2}{*}{ Epifitas (\%) } \\
\hline & Nativas & Cultivadas & Nativas & Cultivadas & & & \\
\hline R1 & 14,3 & 14,3 & 1,2 & 16,7 & 46,4 & 4,8 & 1,2 \\
\hline R2 & 16,8 & 18,8 & 2,0 & 20,8 & 34,7 & 5,0 & 2,0 \\
\hline C1 & 13,6 & 12,7 & 3,6 & 17,3 & 50,0 & 2,7 & 0,0 \\
\hline $\mathrm{C} 2$ & 14,7 & 13,3 & 4,0 & 32,0 & 38,3 & 2,7 & 0,0 \\
\hline C3 & 18,5 & 7,4 & 1,9 & 20,4 & 50,0 & 1,9 & 0,0 \\
\hline PP1 & 6,8 & 16,4 & 0,0 & 6,8 & 45,2 & 1,4 & 0,0 \\
\hline PP2 & 10,2 & 11,2 & 4,1 & 29,6 & 40,8 & 4,1 & 0,0 \\
\hline PP3 & 9,1 & 19,7 & 0,0 & 36,4 & 34,8 & 0,0 & 0,0 \\
\hline PB1 & 26,3 & 12,1 & 6,1 & 21,2 & 29,3 & 4,0 & 0,0 \\
\hline PG1 & 13,8 & 7,4 & 1,1 & 19,1 & 56,4 & 0,0 & 1,1 \\
\hline PG2 & 15,8 & 6,6 & 3,9 & 14,5 & 57,9 & 1,3 & 0,0 \\
\hline PG3 & 18,1 & 4,2 & 2,8 & 2,8 & 63,9 & 0,0 & 4,2 \\
\hline PR1 & 25,0 & 10,4 & 2,1 & 27,1 & 31,3 & 2,1 & 0,0 \\
\hline PR2 & 5,9 & 21,5 & 0,0 & 29,4 & 41,2 & 0,0 & 2,0 \\
\hline CZ1 & 0,0 & 20,0 & 4,0 & 0,0 & 52,0 & 0,0 & 0,0 \\
\hline CZ2 & 7,7 & 11,5 & 0,0 & 19,2 & 61,5 & 0,0 & 0,0 \\
\hline BA1 & 12,5 & 15,6 & 6,3 & 34,4 & 31,3 & 0,0 & 0,0 \\
\hline BA2 & 19,5 & 22,0 & 0,0 & 17,1 & 39,0 & 2,4 & 0,0 \\
\hline BA3 & 0,0 & 18,8 & 0,0 & 6,3 & 75,0 & 0,0 & 0,0 \\
\hline
\end{tabular}

Como pode ser observado pelos dados acima, todos os quintais apresentam em sua estrutura vertical espécies que representam os principais estratos, o que também, junto à diversidade de espécies, é uma forte característica desses sistemas. O que diferencia os quintais estudados quanto a estrutura vertical é a proporção encontrada em relação às espécies nativas e cultivadas, assim como em relação as proporções entre os estratos, embora o estrato herbáceo 
seja predominante em riqueza de espécies, o estrato arbóreo na maioria dos quintais também está bastante presente, determinando um ambiente sombreado. Essa discussão está baseada apenas em dados referentes à riqueza de espécies, (a escolha de espécies que compõem os quintais), não considerando a abundância, pois em alguns casos, mesmo o quintal apresentando pouca diversidade compondo um determinado estrato, isto não significa que este não seja predominante nesse ambiente, tendo apenas uma ou poucas espécies em abundancia 0 representando. Poderia citar como exemplo, o predomínio de bananeiras, mangueiras, jaqueiras, abacateiros, citrus e goiabeiras, além dos plantios de café, que logo em um primeiro olhar, são abundantes em muitos quintais do Saco do Mamanguá.

No caso do Mamanguá, uma das características dos seus quintais passível de ser considerada, é a presença de espécies nativas nos diferentes estratos, fato que além de contribuir para o aumento da diversidade destes, oferece também diferentes usos e que estão diretamente relacionados aos recursos locais da Floresta Atlântica, este fato entre outros, me permiti reconhecer nesse espaço, um local de transição entre a floresta e a casa.

O estrato arbóreo nos quintais é formado por espécies cultivadas (em geral fruteiras) e nativas que cumprem diversas funções, além do fornecimento de frutos comestíveis. São utilizadas como "quebra-vento" e também propiciam sombra, com isso mantêm os quintais "limpos", não permitindo o crescimento do mato, ou então criam o microhabitat ideal para 0 cultivo de ornamentais, medicinais e condimentares. Um exemplo dessa situação é as mangueiras (Mangifera indica) do Mamanguá que raramente produzem frutos, principalmente no lado continental, onde a incidência solar é menor, mas os moradores as deixam, pois reconhecem tais funções nessa fruteira de grande porte. A sombra produzida pelas espécies arbóreas também possui um significado importante para os moradores, ao criarem um microclima agradável nesse espaço, muito diferente da roça, por exemplo. A prevalência da sombra nos quintais faz com que os estratos inferiores sejam ocupados por espécies menos exigentes quanto a incidência luminosa e que requeiram pouca mão-de-obra para produção para consumo próprio. Mas, ao compor os quintais outras funções ou valores das espécies nativas são percebidos pelos moradores e não são tão visíveis ao primeiro olhar. O palmito jiçara (Euterpe edulis), é um exemplo citado durante as entrevistas. Ao observarem a escassez dessa espécie devido ao corte predatório e a dificuldade de encontrarem palmito nas proximidades, alguns entrevistados 
afirmaram plantar o palmito em seus quintais ou em suas posses, onde assim, poderiam cuidar e os palmiteiros não cortariam. A caixeta (Tabebuia cassinoides), outro exemplo, por seu valor comercial, pois dela fazem o artesanato, plantam (estacas) ou deixam crescer aquelas que "nasceram sozinhas" em seus quintais (brotaram dos tocos ou estacas esquecidas nos quintais que seriam utilizados para confecção de peças), mesmo sendo estes bem diferentes do habitat natural dessa espécie. A aroeira (Schinus terebintifhifolius) e o mangue do mato (Rapanea guyanensis) foram também citadas como "chama passarinho" e por isso, os moradores gostam de tê-las próximas às casas.

O estrato arbustivo é composto em sua grande maioria em todos os quintais, por espécies cultivadas, que são destinadas principalmente à alimentação, como por exemplo, os citrus (Citrus sp), café (Coffea arabica) e bananeiras (Musa sp). Neste estrato ao contrário do que se viu no anterior, são observadas poucas representantes de espécies nativas, sendo que alguns quintais, chega a ser nula a existência destas. Parte das plantas ornamentais também são encontradas nesse estrato, junto ainda com algumas medicinais de porte arbustivo, como 0 sabugueiro (Sambucous nigra), estomalina (Vernonia condesata), maria preta (Vernonia scorpioides) e boldo arbusto (Plectrantus cf barbatus). Porém, é no estrato herbáceo onde se concentram a maior parte das ornamentais, medicinais e condimentares. Ao realizar 0 levantamento junto à coleta botânica, considerei apenas as plantas herbáceas que são conhecidas e utilizadas pelos moradores, nesse estrato encontram-se também representantes de espécies nativas, mas no caso, não cheguei a diferenciá-las.

- Os perfis verticais e os diferentes estratos que compõem o sistema

Os dos dados coletados sobre as categorias de uso e os diferentes estratos presentes nos quintais revelam a vocação ou o potencial de cada quintal, que cumprem funções específicas de acordo com as necessidades e escolhas de seus moradores. A seguir serão apresentadosdos os perfis verticais de algumas parcelas dos quintais, seguidos dos croquis, onde também será possível visualizar a estrutura horizontal dos quintais e como se dá a divisão do espaço em áreas de manejo. 


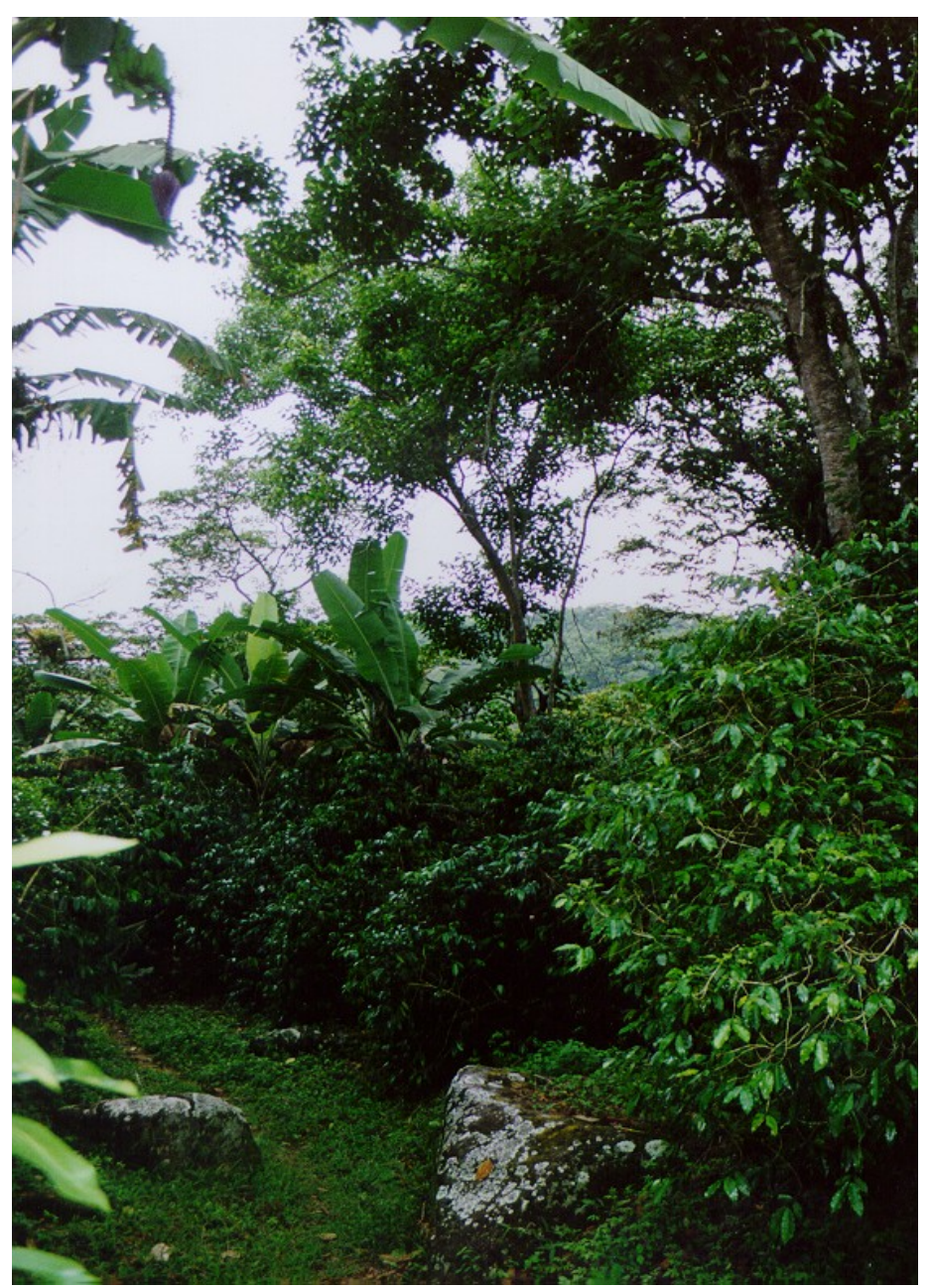

Figura 18 - Exemplo da estrutra vertical de um quintal e os difentes consórcios formados

Nos perfis que seguem abaixo são observados de três a quatro estratos, desde o estrato herbáceo até o arbóreo, sendo que este último não ultrapassa a média dos doze metros de altura. 


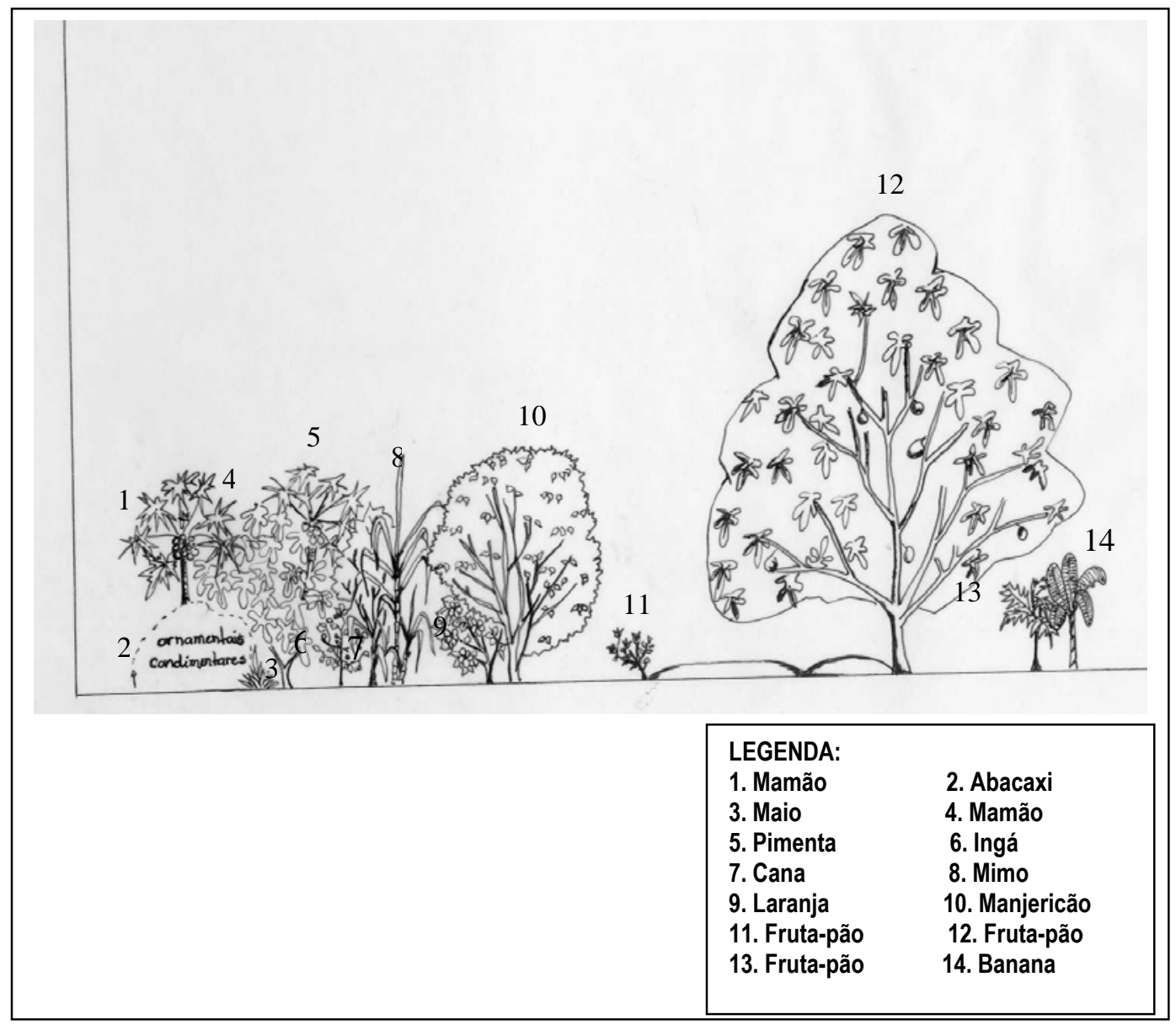

Figura 19 - Perfil vertical do Grupo Familiar R1 - Regate

Neste perfil são observadas principalmente espécies destinadas à alimentação, compondo os três principais estratos. As plantas ornamentais e medicinais estão localizadas mais próximas a casa. Embaixo do pé de fruta-pão, encontra-se o local de trabalho de toda a família que confecciona artesanato de caixeta, enquanto os filhos mais novos e o neto brincam no terreiro. 


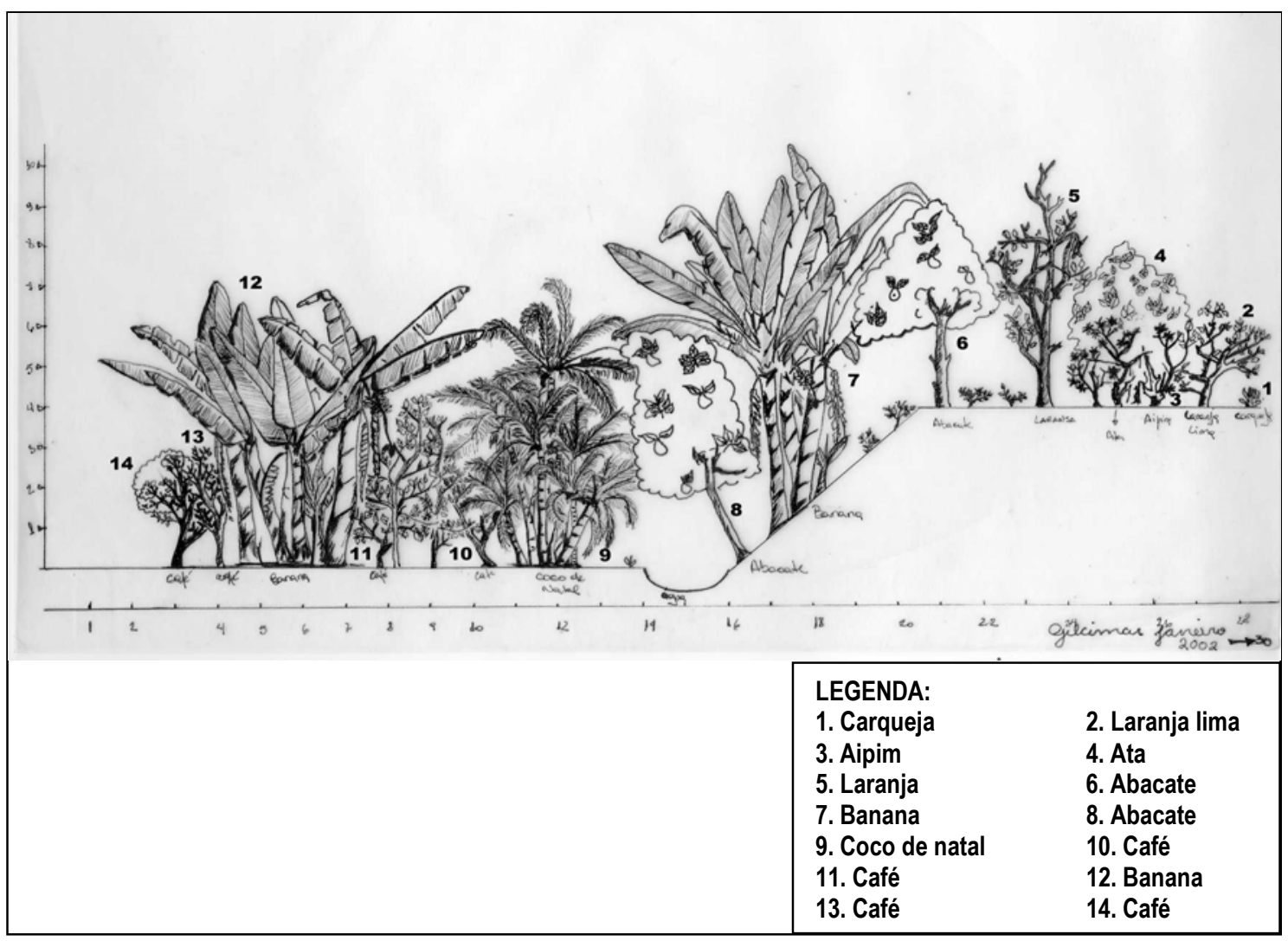

Figura 20 - Perfil vertical do Grupo Familiar R2 - Regate

Este perfil foi feito pelo filho mais novo desse grupo familiar, a parcela representada inicia-se próxima a casa, e aqui também são observadas principalmente espécies destinadas à alimentação. As árvores maiores, inclusive nativas, localizam-se mais distantes e onde também se encontram cultivos muito antigos de café sombreado. 


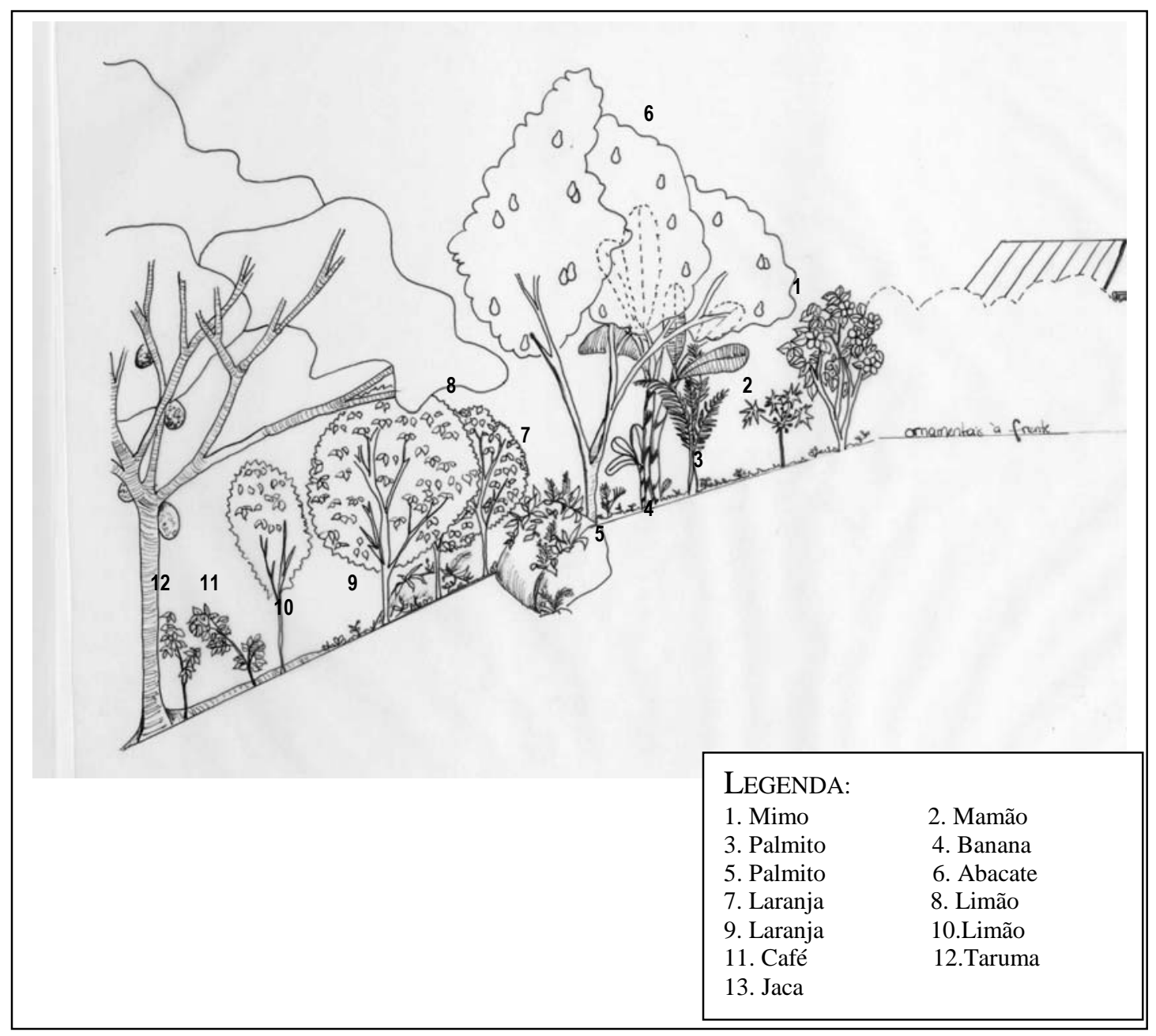

Figura 21 - Perfil vertical do Grupo Familiar C1 - Curupira

Neste quintal o perfil mostra a presença de espécies nativas e espécies frutiferas, compondo o estrato arbóreo bem desenvolvido, oferecendo bastante sombra e onde encontra-se o palmito e a pupunha. As plantas que compõem o estrato herbáceo não foram identificadas, mas este se encontra bem diverso além da presença de aráceas e outras epífitas. 


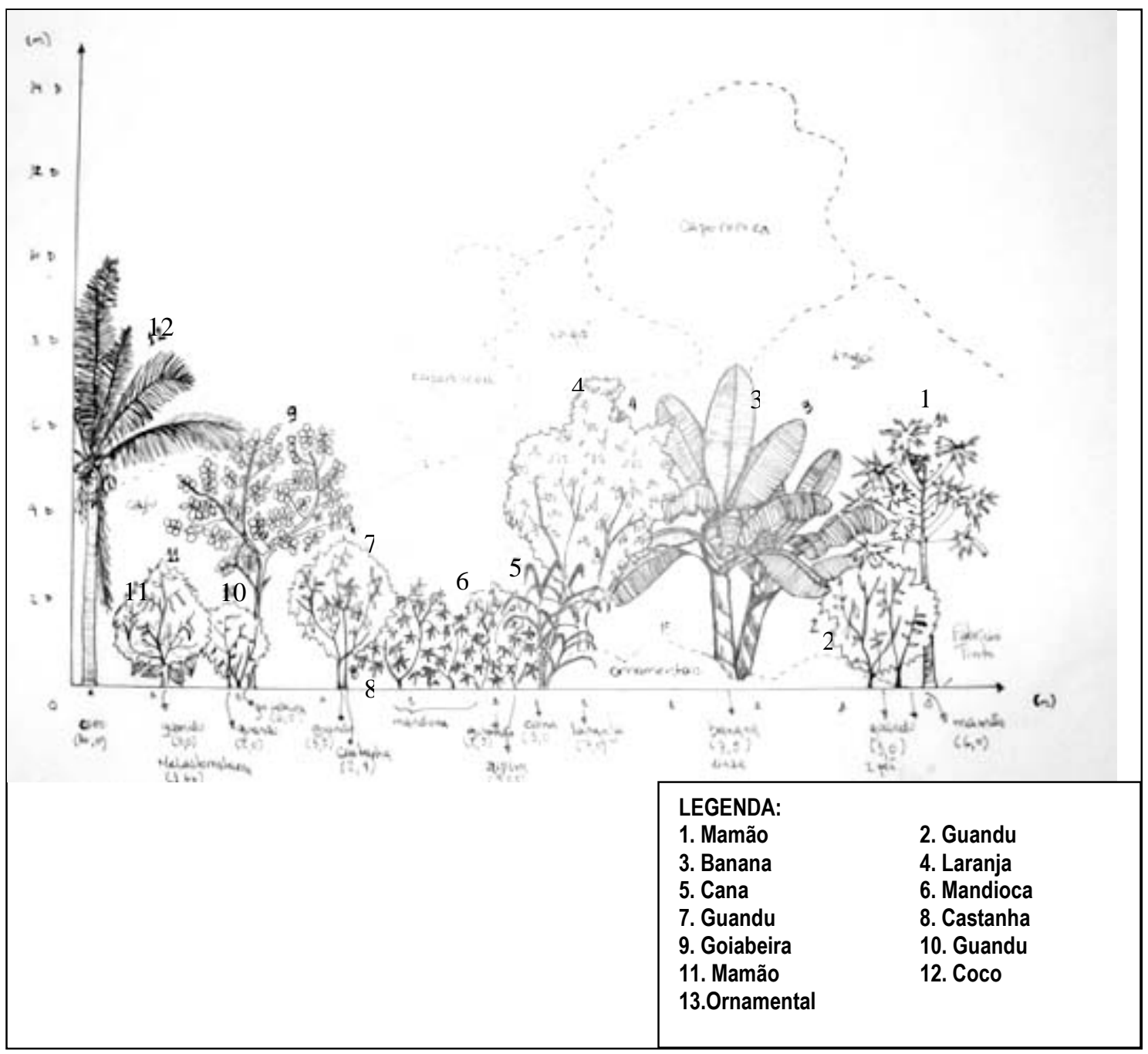

Figura 22 - Perfil vertical do Grupo Familiar C3 - Curupira

Neste grupo familiar, o quintal possuía cerca de um ano apenas, quando realizei o trabalho de campo, mas uma estrutura vertical com relativa riqueza de espécies, já podia ser observada, em comparação aos outros quintais estudados. Nesse quintal também são observados os plantios de aipim e batata doce formando consórcio com o guandu. 


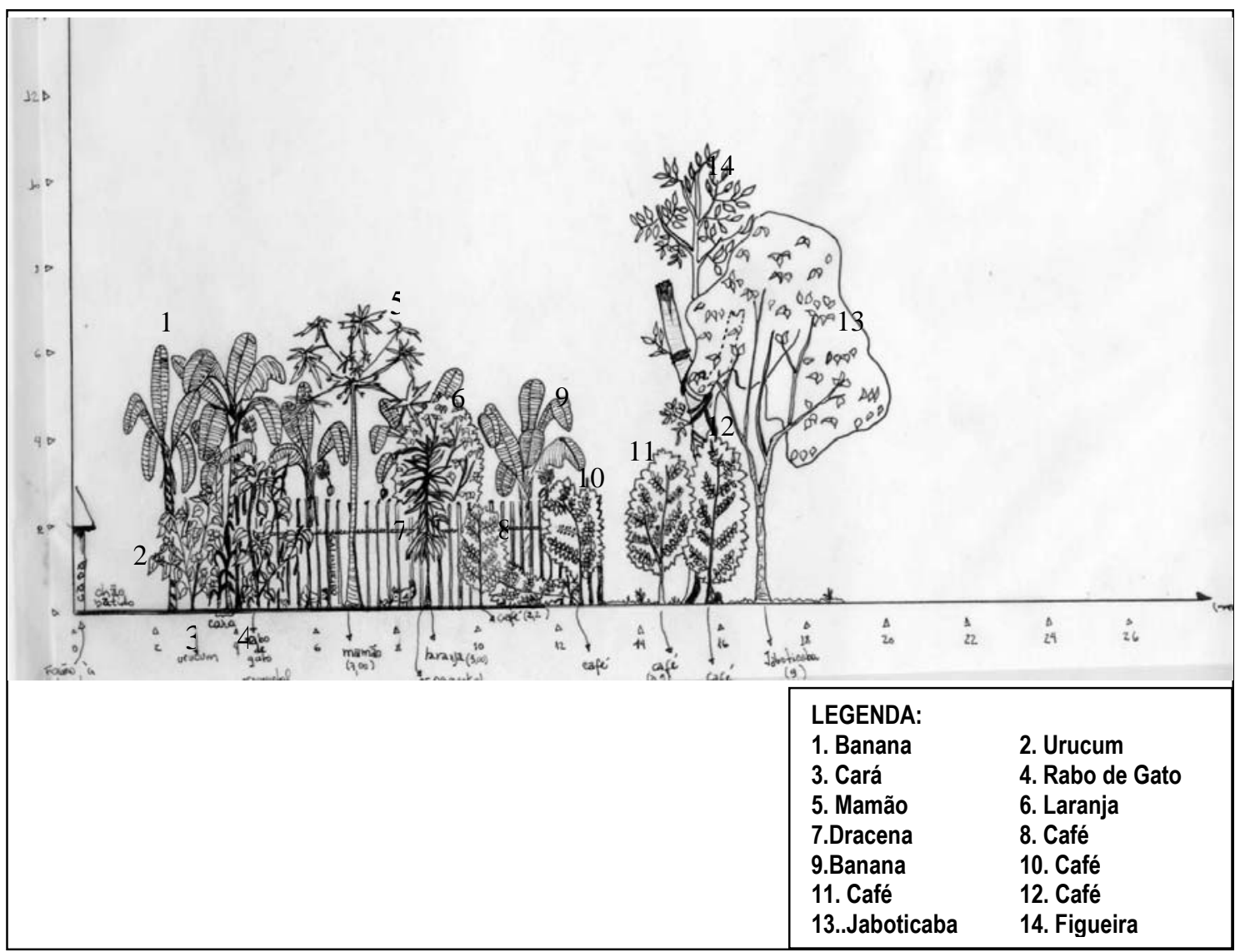

Figura 23 - Regate Perfil vertical do Grupo Família PP1- Praia do Pontal

Neste perfil são observados principalmente dois estratos (arbóreo e arbustivo) compostos por espécies destinadas à alimentação, o café sombreado, além do galinheiro cercado por bambu, onde nascem bananeiras e pés de mamão. 


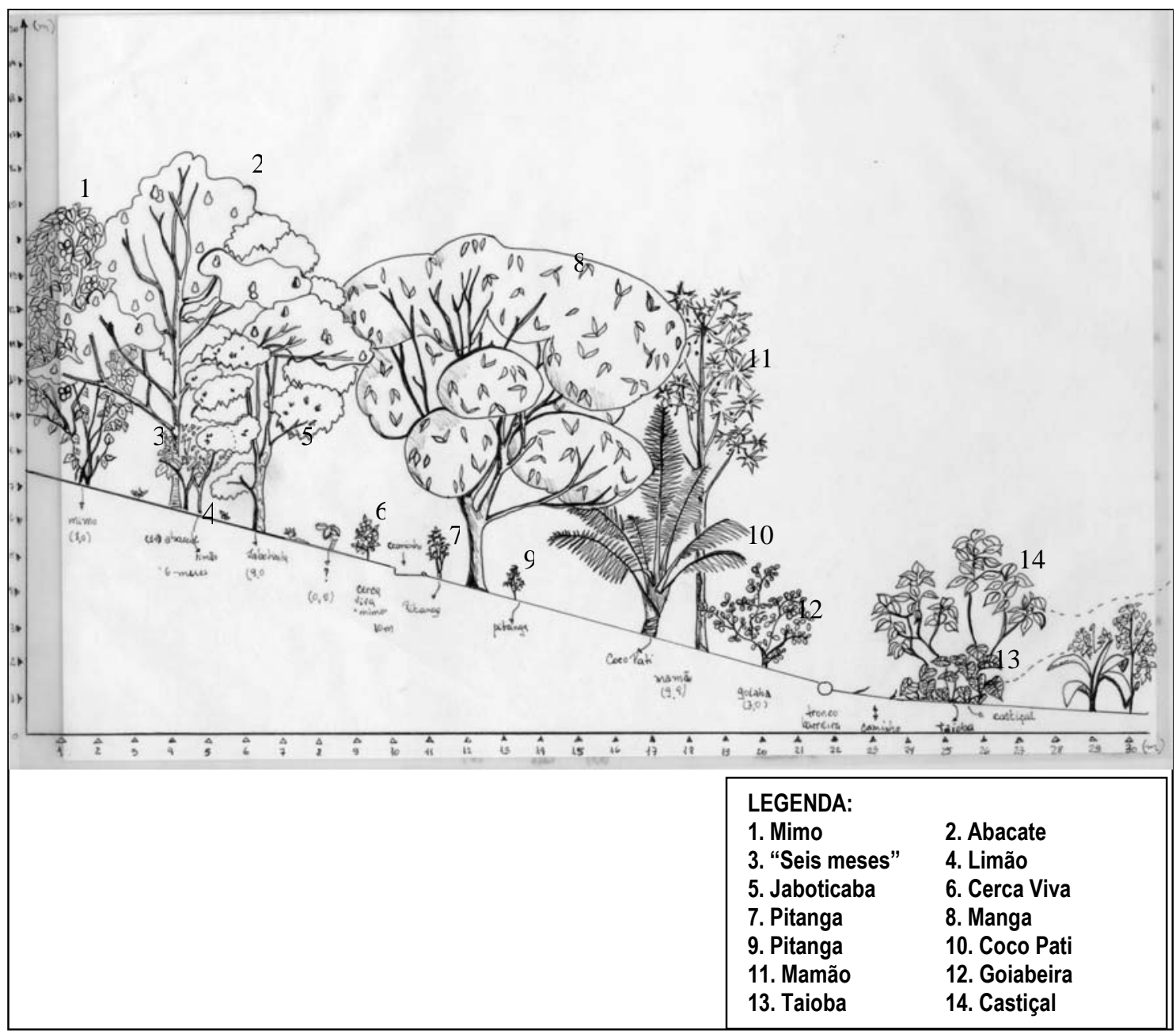

Figura 24 - Perfil vertical do Grupo familiar PB1- Praia da Bica

Neste perfil é observada a predominância do estrato arbóreo composto especialmente por fruteiras. Na baixada onde se concentra "o estrume", a terra boa, são cultivadas plantas medicinais (boldo), condimentares e a taioba que gosta de lugares úmidos. 


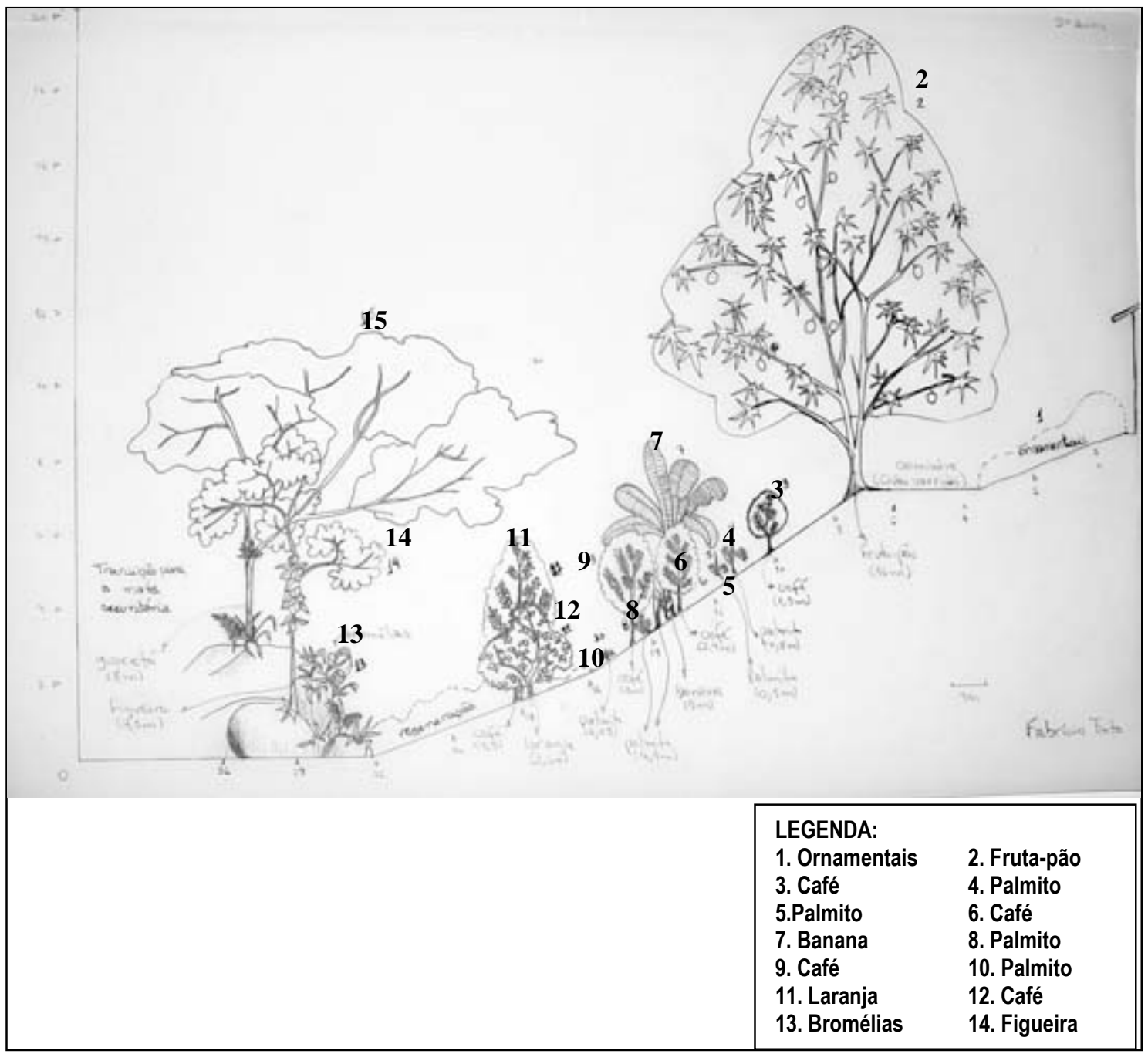

Figura 25 - Perfil vertical do Grupo Familiar PG1 - Praia Grande

Neste perfil, os três estratos são observados, com a presença de nativas, nesse local encontra-se também café sombreado, citrus e um banco de plântulas de palmito. 


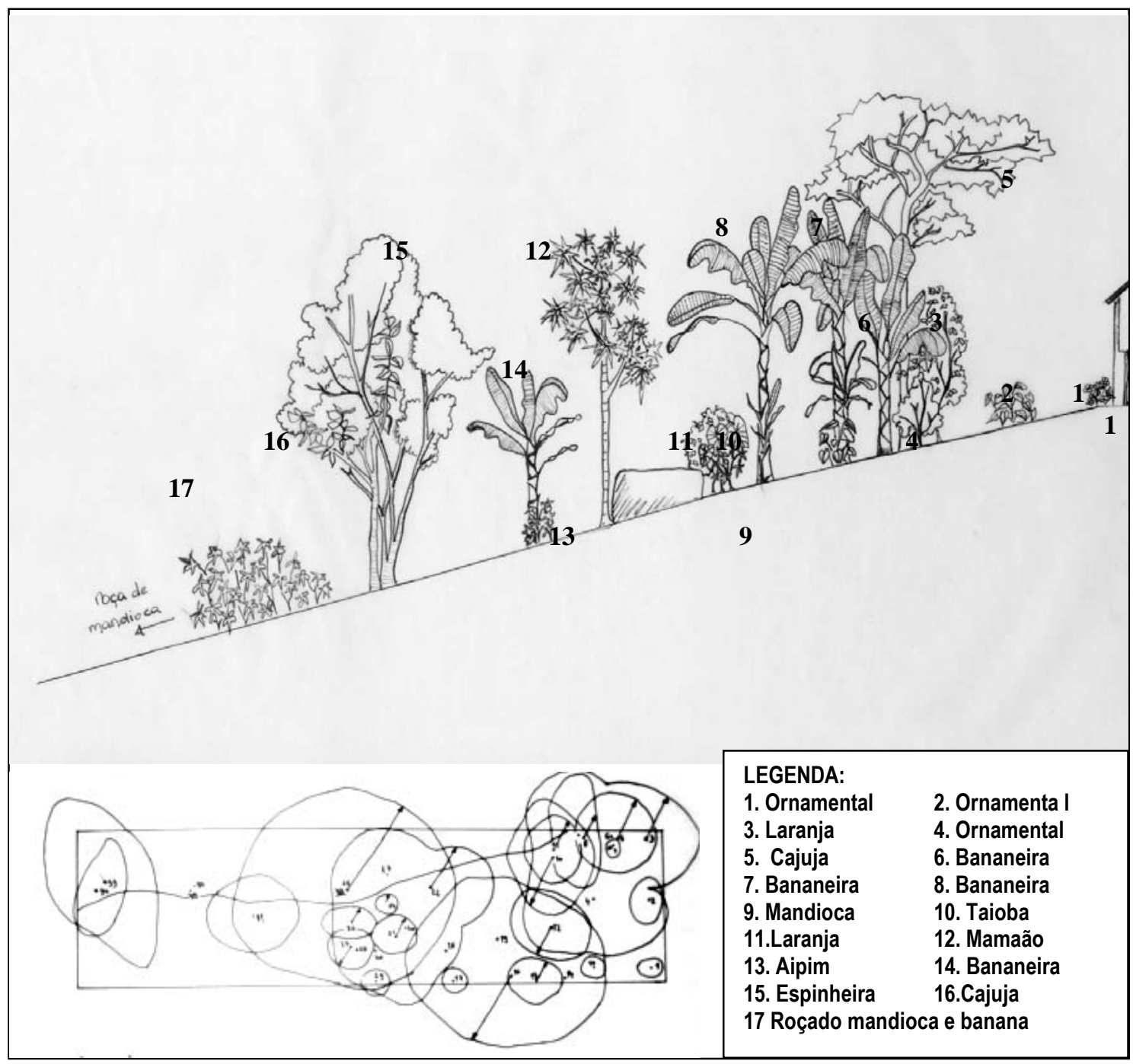

Figura 26 - Perfil vertical do Grupo Familiar PR1 - Ponta da Romana

Nesse perfil é possível identificar a predominância do estrato arbóreo com espécies nativas e frutíferas, e logo a seguir encontra-se o plantio de mandioca, da pequena roça, com a presença de bananeiras. A qui também está apresentada a projeção das copas desse perfil. 


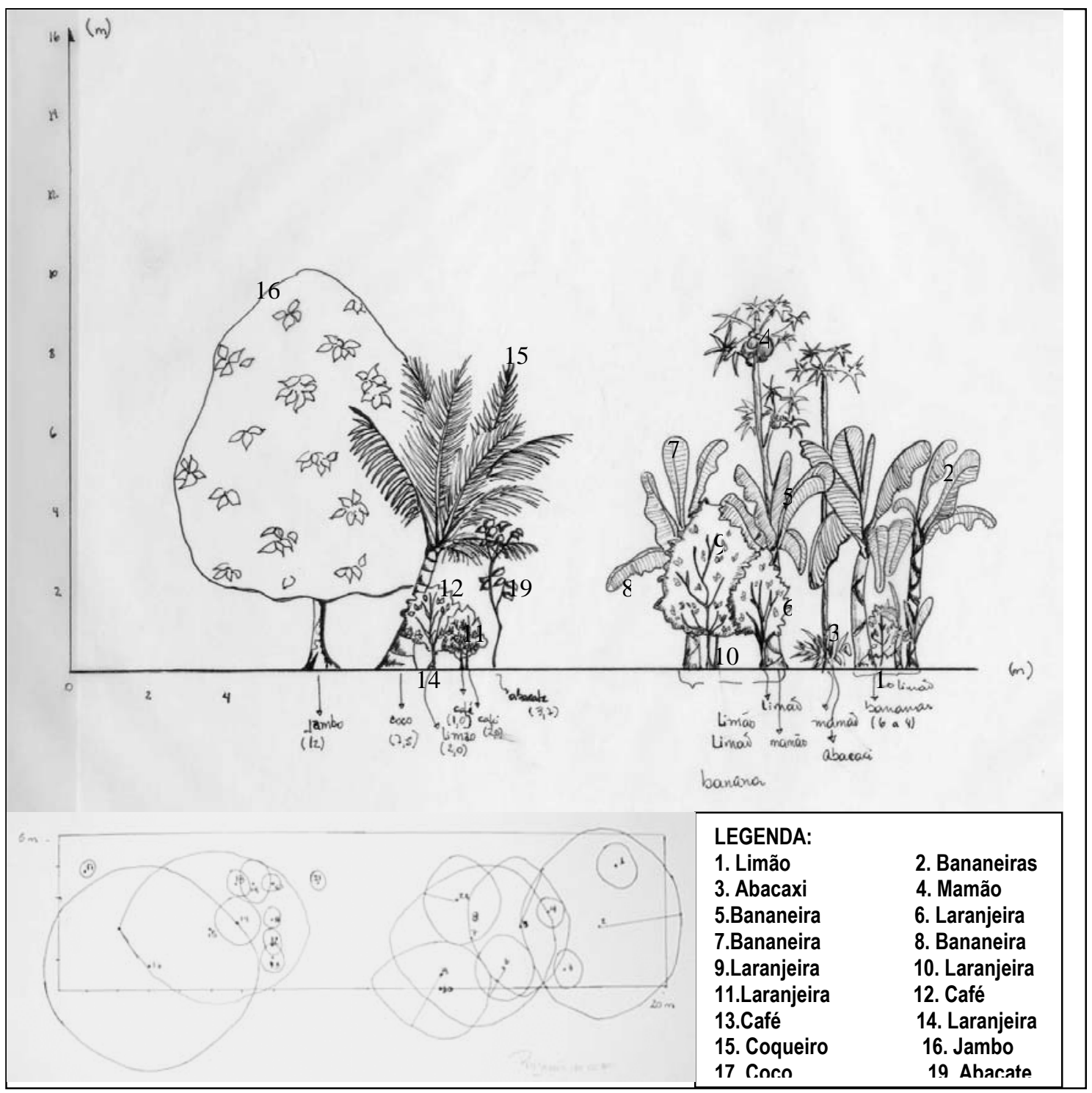

Figura 27 - Perfil vertical do grupo familiar PR2 - Ponta da Romana

Aqui observa-se a presença dos estratos arbóreos e arbustivos, e fruteiras compondo consórcios, como por exemplo, bananeiras e citrus, logo abaixo está representada a parcela (5m $X$ 20) com a projeção de copas. 
- Exemplos de consórcios presentes nos quintais agroflorestais

Como já mencionei antes, a predominância de espaços sombreados é determinante nas escolhas dos cultivos dos estratos inferiores nos quintais. Com a apresentação dos perfis foi possível observar a presença de café sombreado nos diferentes grupos familiares e em muitos quintais estes plantios foram observados compondo consórcios com bananeiras ou outras fruteiras e árvores nativas. Muitas ornamentais são observadas próximas às casas e estas são plantadas junto às plantas medicinais, condimentares e aos tubérculos (taioba, batata-doce), formando o estrato herbáceo. E algumas vezes, estas ainda se encontram sob a copa de arbustos e fruteiras de menor porte ou árvores nativas, no caso mais distantes da casa. Apresento abaixo alguns exemplos de consórcios encontrados nos quintais com as plantas que ocupam os três principais estratos (Quadro 6):

\begin{tabular}{|c|l|l|l|}
\hline \multirow{2}{*}{ GF } & \multicolumn{3}{|l|}{ Exemplos de Consórcios Encontrados } \\
\cline { 2 - 4 } & Estrato Superior & Estrato Médio & Estrato Baixo \\
\hline \multirow{2}{*}{ R1 } & Goiabeira & Café & Cará \\
\cline { 2 - 4 } & Laranjeira & Café & \\
\hline \multirow{4}{*}{ R2 } & Ingazeiro & $\begin{array}{l}\text { Jabuticaba + banana + } \\
\text { café Laranjeira + café }\end{array}$ & \\
\cline { 2 - 4 } & Guapurubu & Laranjeira + café & \\
\cline { 2 - 4 } & $\begin{array}{l}\text { Ingazeiro } \\
\text { jabuticabeira }\end{array}$ & Bananeira e café & \\
\hline \multirow{3}{*}{ C1 } & Jaqueira + cambucá & Laranjeira & \\
\cline { 2 - 4 } & Jaqueira + Cambucá & $\begin{array}{l}\text { Pupunheira + palmito } \\
\text { jiçara + bananeira }\end{array}$ & \\
\cline { 2 - 4 } & $\begin{array}{l}\text { Jaqueira } \\
\text { pupunheira }\end{array}$ & Laranjeira + café & Ornamentais \\
\hline \multirow{2}{*}{ C2 } & $\begin{array}{l}\text { Cambcá, Figueira e } \\
\text { jaqueira }\end{array}$ & Cacau + laranja + Limão & \\
\cline { 2 - 4 } & Cajueiro & Pimenta, ornamentais \\
\hline
\end{tabular}

Quadro 6 - Exemplos de consórcios observados nos quintais do Mamanguá 


\begin{tabular}{|c|c|c|c|}
\hline \multirow{2}{*}{ GF } & \multicolumn{3}{|c|}{ Exemplos de Consórcios Encontrados } \\
\hline & Estrato Superior & Estrato Médio & Estrato Baixo \\
\hline \multirow{2}{*}{ C3 } & & Guandu + aipim & Batata doce, ornamentais \\
\hline & Bananeira & Mamão & Condimentares ornamentais \\
\hline \multirow{4}{*}{ PP1 } & Ata & Laranja china e cravo & \\
\hline & Cajueiro & Taioba + aipim & Batata doce \\
\hline & Jabuticaba & Café & \\
\hline & $\begin{array}{l}\text { Cajá-manga, fruta- } \\
\text { pão }\end{array}$ & Bananeira e limoeiro & \\
\hline \multirow{2}{*}{ PP2 } & Cedro + nativas & Bananeira & \\
\hline & Palmito & Cana & Medicinais e batata doce \\
\hline PP3 & Figueira & Jabuticabeira e café & \\
\hline \multirow[b]{2}{*}{ PB1 } & Abacateiro & Limoeiro e jabuticabeira & \\
\hline & Mangueira & $\begin{array}{l}\text { Pitangueira, laranjeira e } \\
\text { café }\end{array}$ & \\
\hline PG1 & $\begin{array}{l}\text { Figueira, cedro e } \\
\text { fruta-pão }\end{array}$ & $\begin{array}{l}\text { Bananeira, café, laranja, } \\
\text { palmito }\end{array}$ & $\begin{array}{l}\text { Palmito (banco de plântulas) e } \\
\text { ornamentais }\end{array}$ \\
\hline \multirow{3}{*}{ PG2 } & & $\begin{array}{l}\text { Bananeira, café e } \\
\text { palmito }\end{array}$ & \\
\hline & Jaqueira & Cabaça + Limoeiro & \\
\hline & Figueira & $\begin{array}{l}\text { Guarana, laranjeira + } \\
\text { café }\end{array}$ & \\
\hline PG3 & Ingazeiro & Limoeiro & Taioba, Batata doce, ornam. e med. \\
\hline PR2 & $\begin{array}{l}\text { Mangueira, jaqueira, } \\
\text { jambo }\end{array}$ & $\begin{array}{l}\text { Limoeiro, laranjeira } \mathrm{e} \\
\text { coqueiro }\end{array}$ & Ornamentais \\
\hline CZ1 & Jaqueira & $\begin{array}{l}\text { Pitangueira + laranjeira } \\
\text { Bananeira e café }\end{array}$ & \\
\hline CZ2 & Fruta -pão & Bananeira, laranja e café & \\
\hline \multirow{2}{*}{ BA1 } & Jaqueira & Bananeira, café & \\
\hline & Condessa & & Ornamentais \\
\hline BA2 & Mangueira & Laranjeira & Ornamentais \\
\hline BA3 & Abacateiro & & Medicinal e ornamentais \\
\hline
\end{tabular}

Quadro 6 - Exemplos de consórcios observados nos quintais do Mamanguá 
Sem dúvida que no quadro acima, assim como nos perfis apresentados, há um destaque para os consórcios nos quais estão presentes as fruteiras, contudo, isto não significa que outros diferentes tipos de consórcios sejam formados compondo os estratos verticais e tendo as espécies nativas como componentes, por exemplo. Porém, aqui dei destaque às espécies produtivas, como as fruteiras, dando relevância a um dos principais potenciais, ou função, dos quintais que é a complementação alimentar. Ao apresentar os croquis identificando as diferentes zonas de manejo, outros consórcios poderão ser visualizados.

- As zonas de manejo dos quintais

Nos quintais é possível detectar zonas de manejo que se definem (...)“como áreas ou espaços com estrutura própria, destinadas a usos específicos e com manejo particular" (Lok \& Méndez, 1998). Para distinguir as diferentes zonas de manejo, considerei o componente principal de acordo com as categorias de uso, níveis verticais, presença de consórcios.

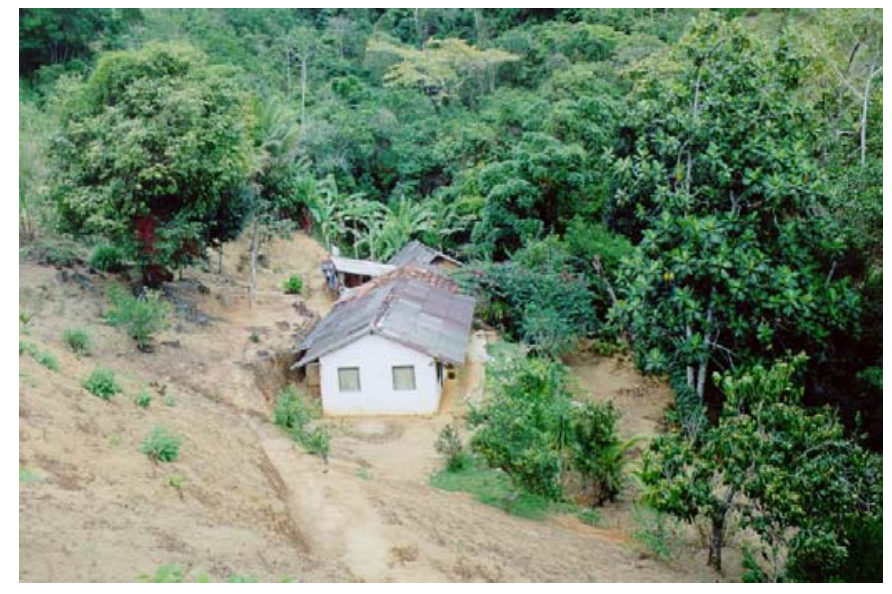

Figura 28 - Vista de um dos quintais estudados e as diferentes zonas de manejo

Foram classificadas doze diferentes zonas de manejo, incluindo a residencial que se caracteriza por espaços livres e chão batido. Nos croquis que foram elaborados é possível visualizar também outros elementos constituintes dos quintais, além dos diferentes cultivos, os locais destinados à criação de animais, o local de trabalho. As benfeitorias de alguma forma traduzem os aspectos da cultura caiçara, como as casas de farinha, as cozinhas de lenha fora da casa e 0 engenho. Nos croquis que serão apresentados a seguir, as diferentes zonas de manejo 
estão identificadas por letras em caixa alta. $\mathbf{A}=$ Área residencial; $\mathbf{B}=$ Ornamentais; $\mathbf{C}=$ Ornamentais com sombra; $D=$ Consórcios entre Fruteiras ; E Fruteiras Arbóreas Isoladas= ; F= Fruteiras e Café; G= Criação; H= Horta ; l= Medicinais e Condimentares; J= Nativas e Fruteiras; L= Cultivos para Alimentação ; $0=$ Outros (Local para Trabalho).

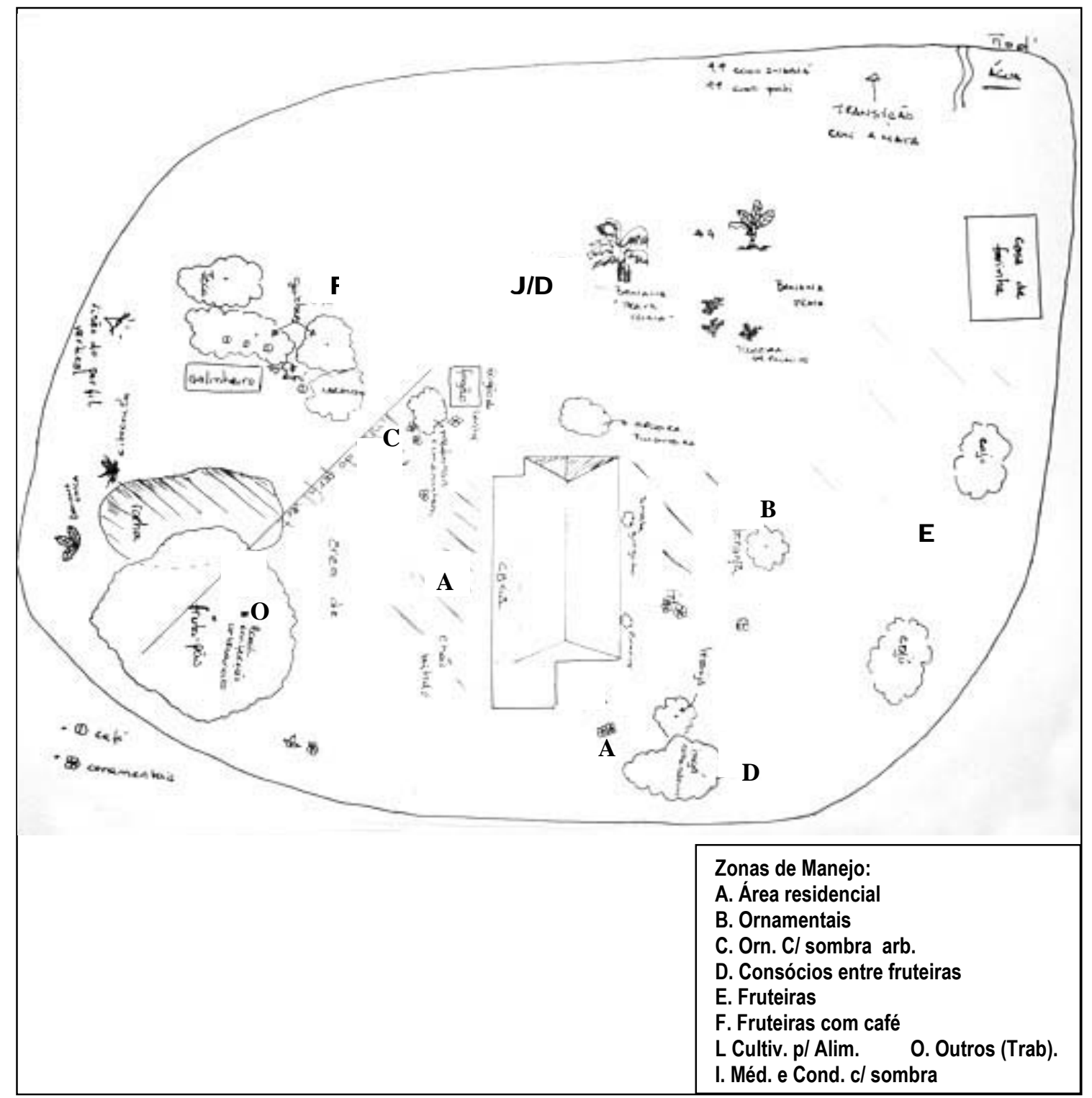

Figura 29 - Croqui do Grupo Familiar do Regate - R1

Nesse grupo pode-se observar oito zonas de manejo, ornamentais mais próximas à casa, sozinhas ou com sombra arbustiva e arbórea, consórcios entre fruteiras e café sombreado, e 
aipim, uma área de transição para mata secundária, com a presença de palmito. Ideentifica-se o local de trabalho, onde é confeccionado o artesanato é à sombra da grande árvore de fruta-pão.

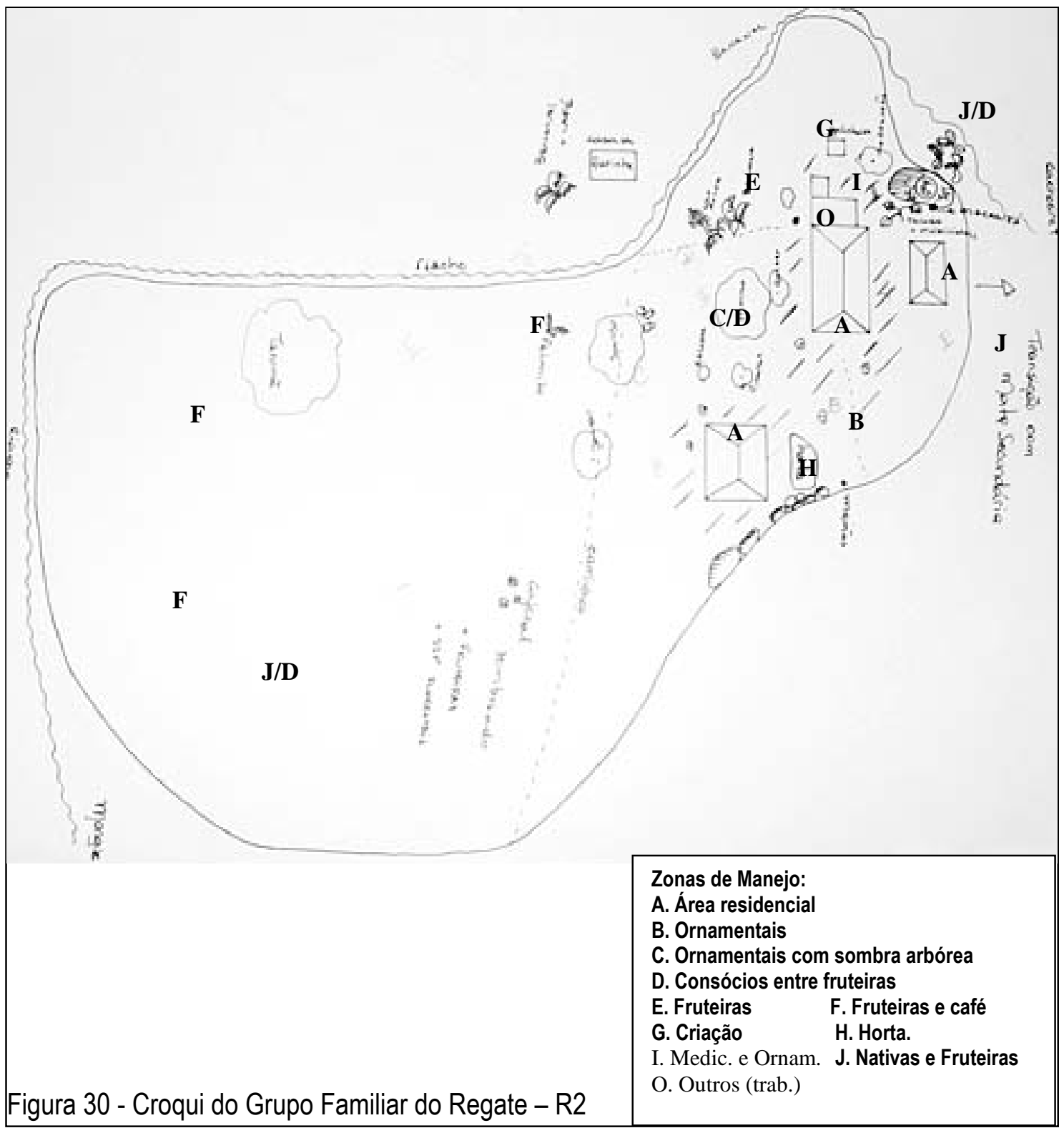

Esse quintal foi o que apresentou o maior número de zonas de manejo, é o mais antigo entre todos que estudei. Nele identifiquei todas as zonas de manejo, exceto cultivos como mandioca, cana, pois a roça está mais distante da casa. Apresenta diferentes espécies nativas que compõem o estrato arbóreo e junto com fruteiras (jaboticabas, citrus, bananeiras) sombreiam o plantio antigo de café. Esse quintal já teve muito citrus, mas hoje em dia abriu espaço para outras fruteiras, ornamentais e atualmente para duas novas casas. 


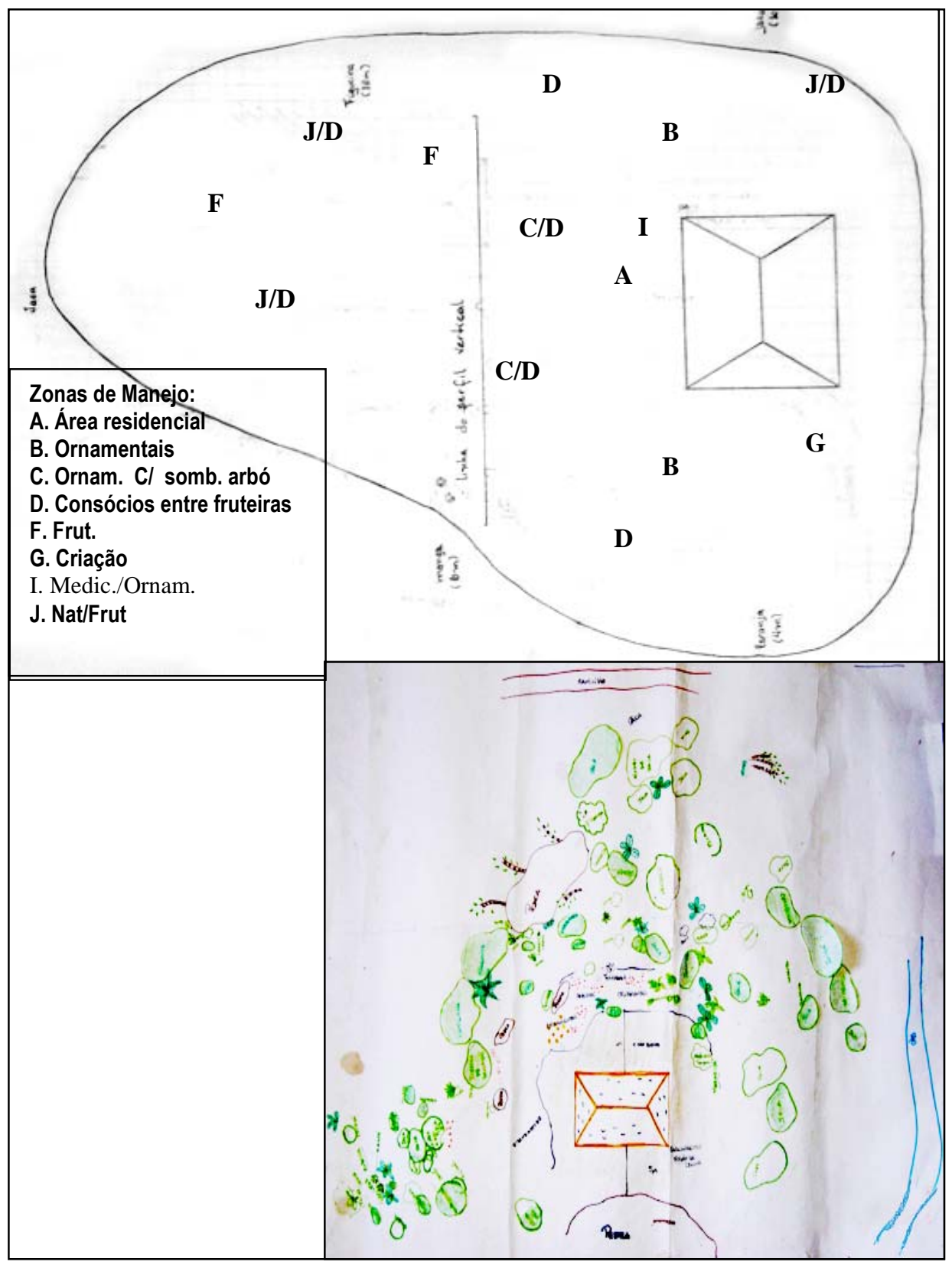

Figura 31 - Croqui do Grupo Familiar do Curupira - C1

Nesse grupo familiar os moradores responsáveis pelo quintal montaram o croqui, localizando os cultivos na área próxima a casa. Aqui identifiquei sete zonas de manejo nesse grupo, com muitas ornamentais ao redor da casa e estrato arbóreo bem marcante após a zona residencial, predominando o ambiente sombreado, com palmito, café sombreado e presença de muitos consórcios entre fruteiras. 


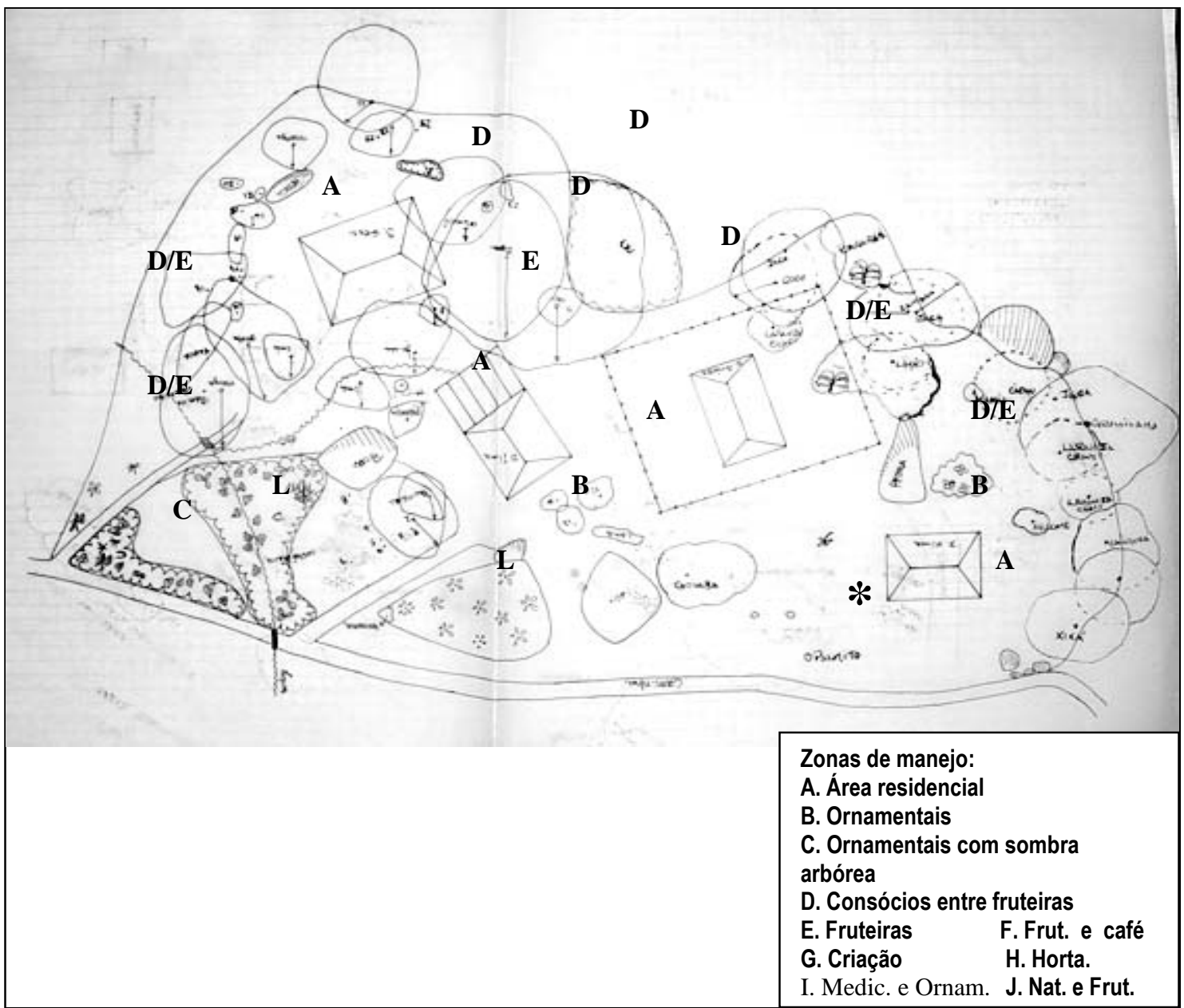

Figura 32 - Croqui do Grupo Familiar do Curupira C2

Esse é um dos quintais mais antigos, já foi dividido entre os filhos e o grupo familiar (identificado com o asterisco) no qual foi desenvolvido o estudo faz parte da área total aqui representada assinalada com asterisco. Contudo, os grandes responsáveis pela manutenção dessa área, ainda continuam sendo os pais, os donos da posse que foi dividida, e as famílias que aí residem se beneficiam de todos os recursos disponíveis. Dessa forma, achei interessante representar o espaço como um todo. O quintal como um todo apresenta o estrato arbóreo também bem desenvolvido, muitas fruteiras e ornamentais, nesse quintal foi feita a projeção das copas das principais árvores e identificados os canteiros de ornamentais compondo consórcios com fruteiras e foram identificadas seis zonas de manejo. 


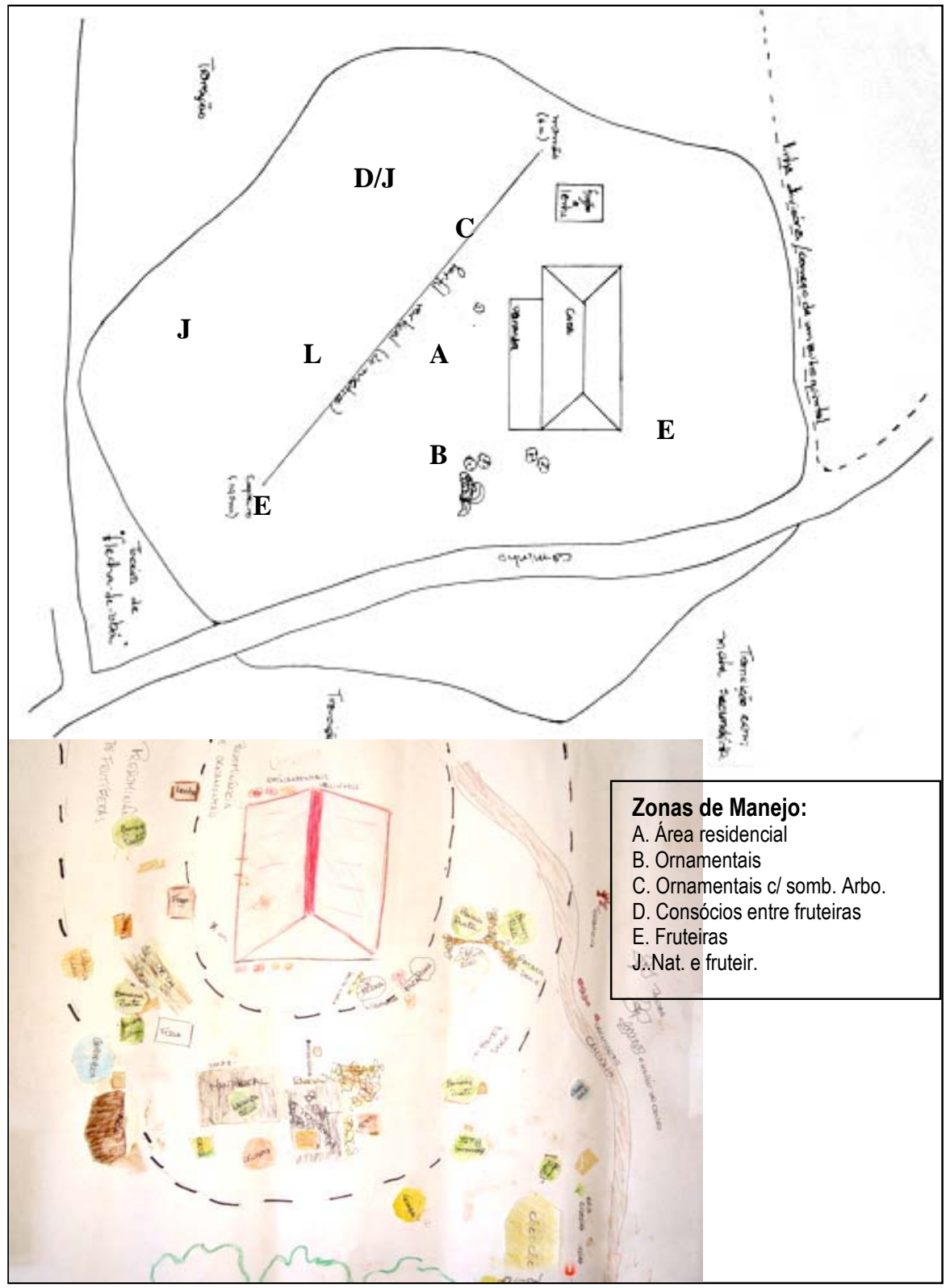

Figura 33 - Croqui do Grupo Familiar do Curupira C3

Esse quintal era o mais recente entre todos os estudados, mas já apresentava uma estrutura vertical desenvolvida e quatro áreas de manejo identificadas, além da área residencial, onde predominam as ornamentais e plantas para temperos, além da presença de maracujá e 
feijão fava. Na borda a presença de espécies arbóreas nativas caracterizando uma área de transição para mata secundária.

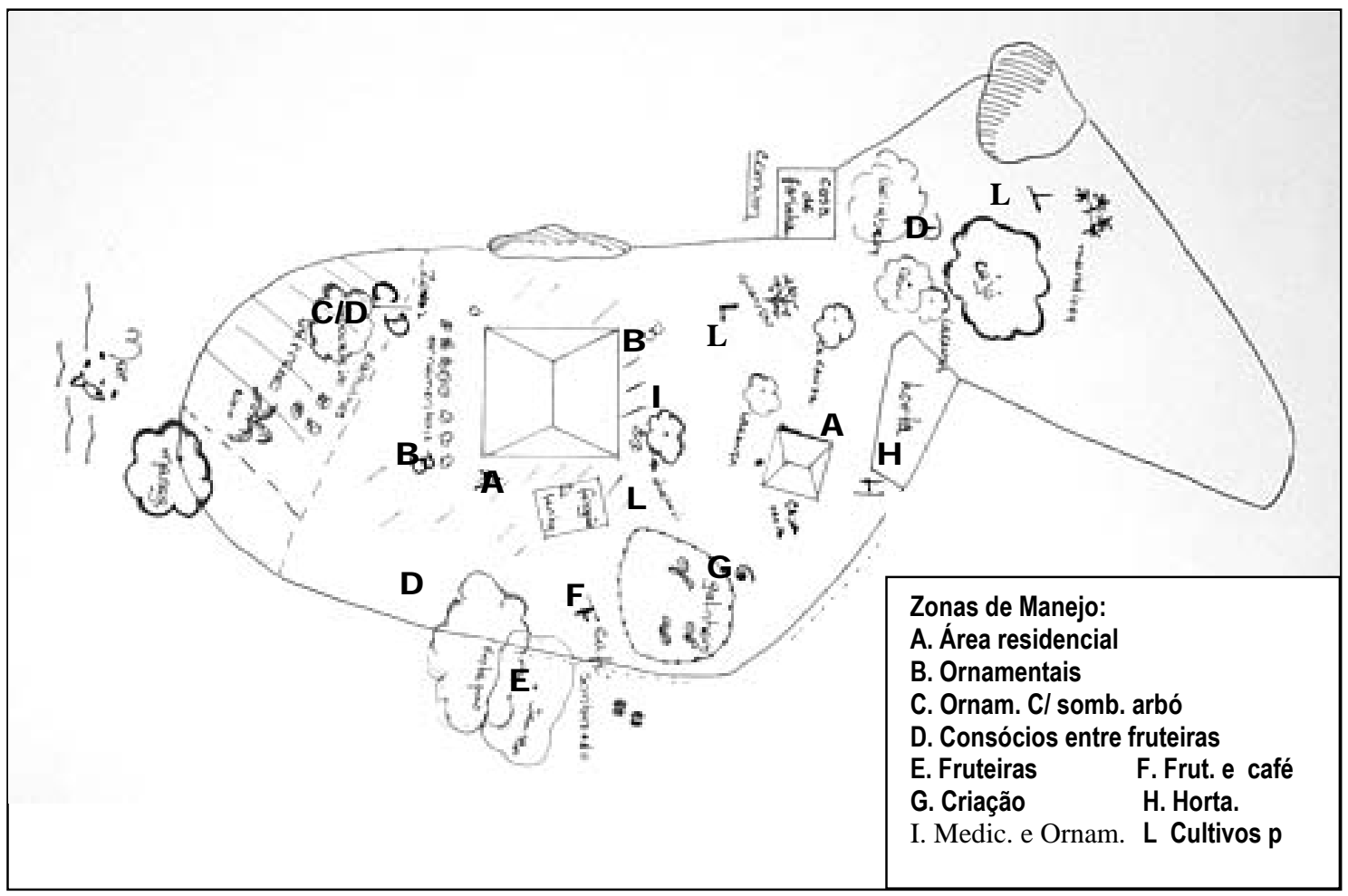

Figura 34 - Croqui do Grupo Familiar da Praia do Pontal PP1

Foram identificadas nove zonas de manejo nesse quintal, excluindo a zona residencial, com a presença de horta, galinheiro, casa de farinha, além de consórcios entre fruteiras e cultivo de guandu, mandioca, batata doce. 


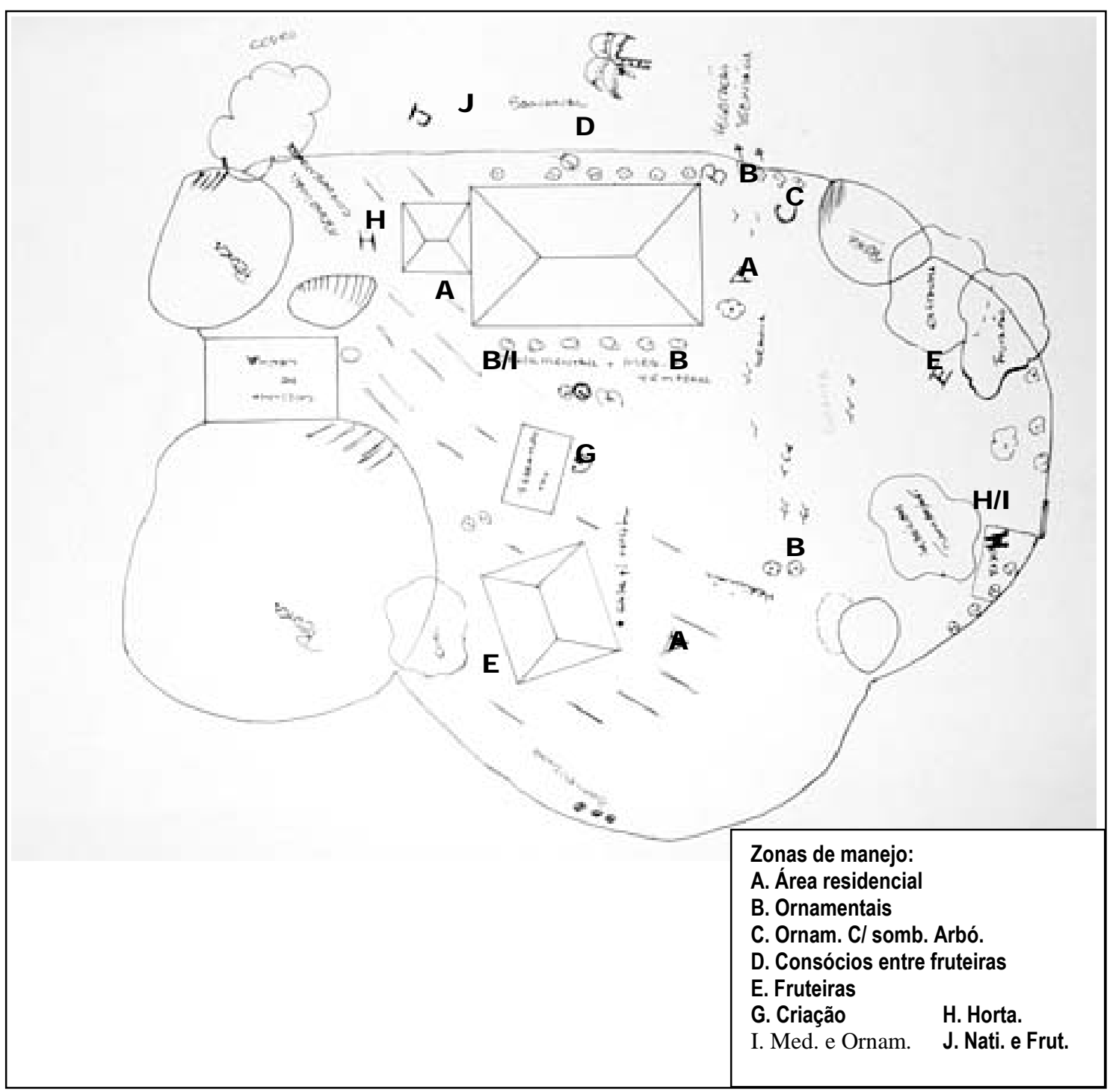

Figura 35 - Croqui do Grupo Familiar da Praia do Pontal - PP2

Esse quintal apresenta oito zonas de manejo, como a maioria dos quintais, grande parte das ornamentais está próxima a casa e os estratos mais altos ocupam zonas mais distantes, e são compostos por espécies frutiferas e outras nativas e exóticas, como por exemplo flamboyant e a castanha. Outro destaque, é para a construção de uma nova casa para ser alugada para turistas. 


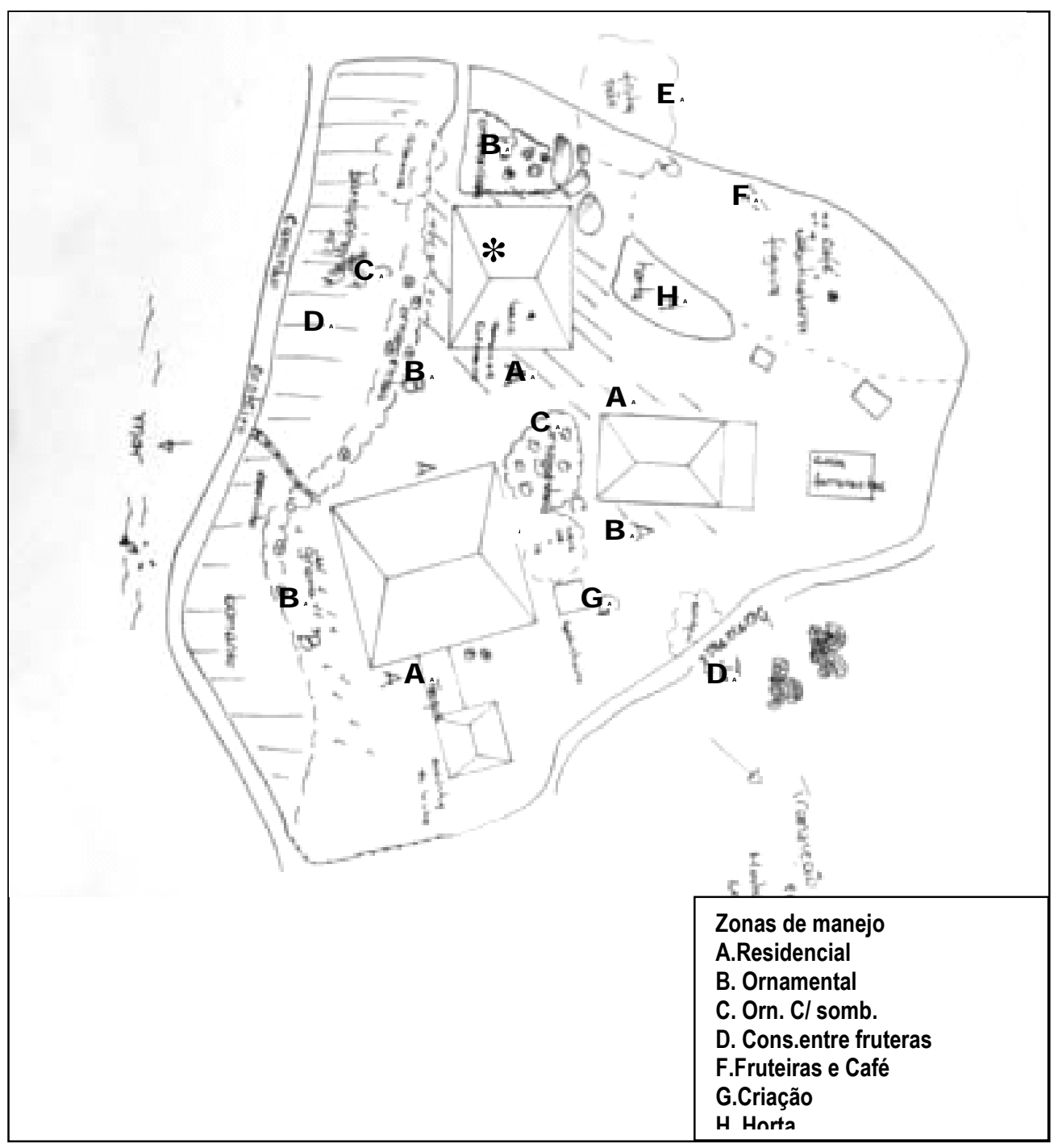

Figura 36 - Croqui do Grupo Familiar - PP3

O grupo familiar estudado (identificado com o asterisco) faz parte da área aqui representada, mas como no caso do grupo familiar C2, este espaço foi dividido entre os filhos. Os recursos disponiveis são utilizados por todas as famílias que residem nesse quintal, inclusive a horta, a criação de galinhas e a produção de ovos e por esta razão o quintal foi representado com todas as casas. Ao redor das casas predominam as ornamentais e no estrato arbóreo tem-se as fruteiras compondo consórcios e sombreando o café e um pouco mais distante o bananal junto às espécies nativas que caracterizam uma área de transição para mata secundária e ao todo podese identificar seis zonas de manejo. 


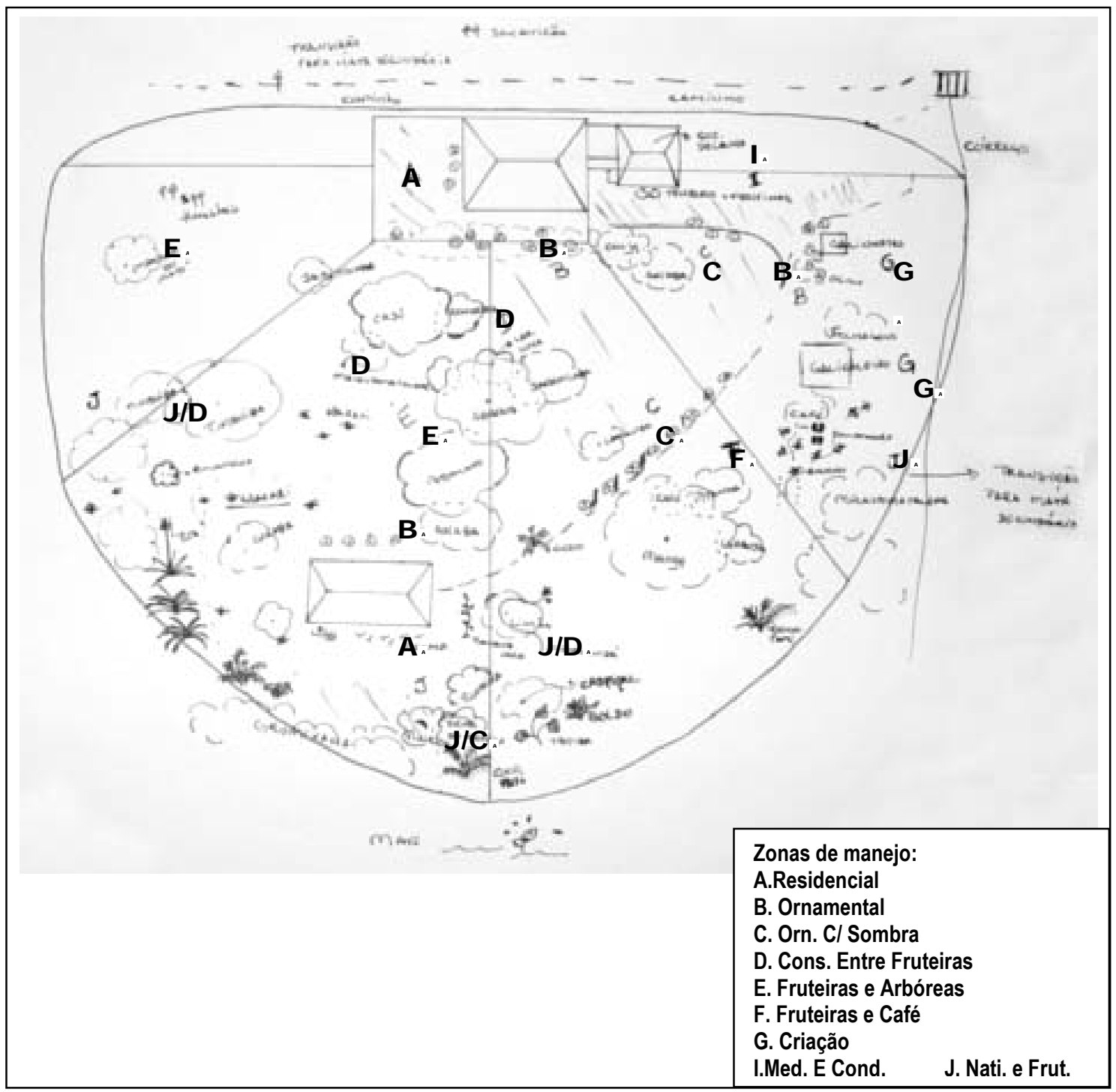

Figura 37 - Croqui do Grupo Familiar da Praia da Bica - PB1

Esse quintal apresenta oito zonas de manejo, sendo que uma forte característica é a predominância do estrato arbóreo com espécies nativas, muitos consórcios são formados entre fruteiras, observa-se também a existência de café sombreado. Nesse quintal também foi construída uma nova casa, que é alugada para turistas. 


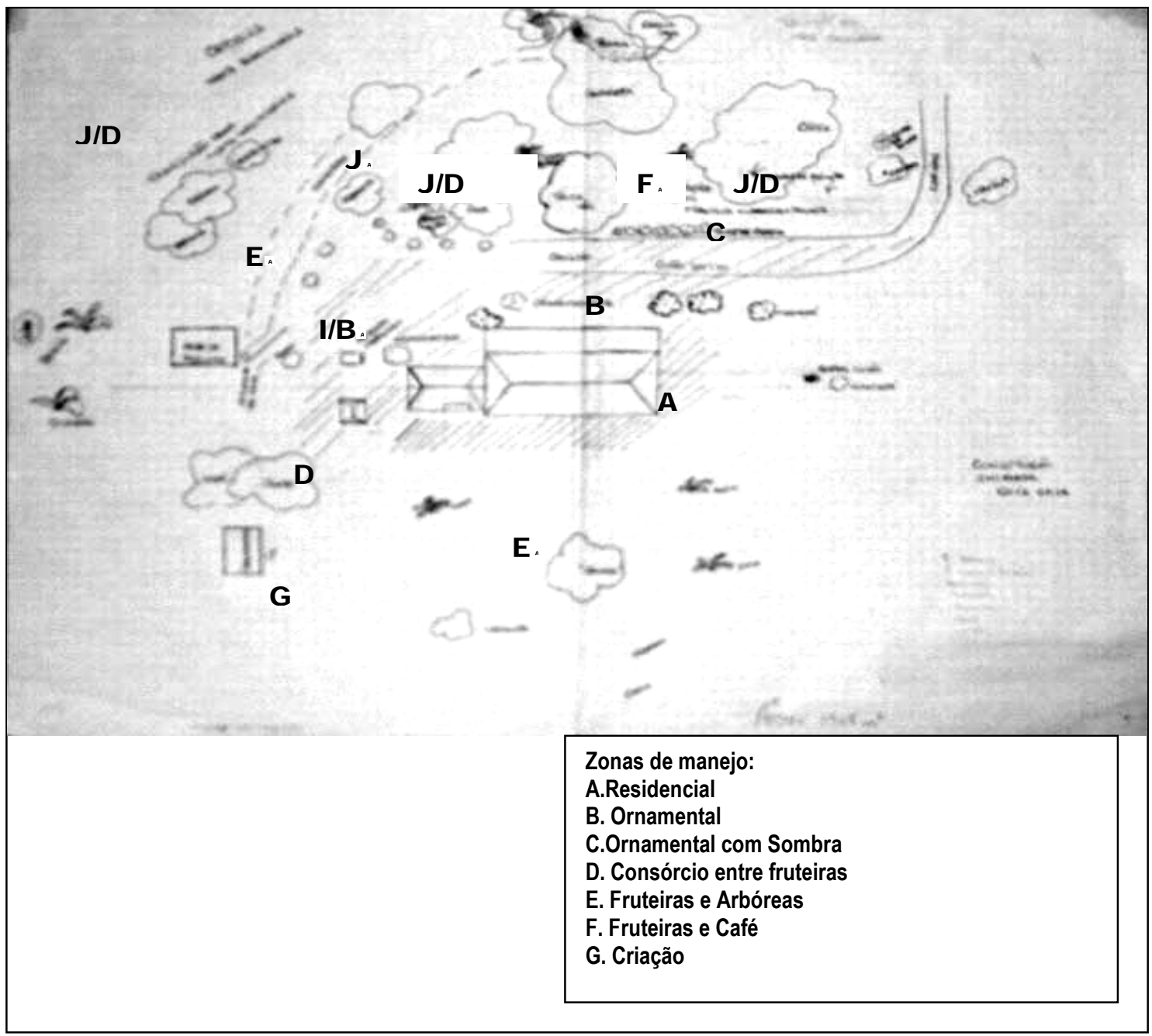

Figura 38 - Croqui do Grupo Familiar da Praia Grande - PG1

Esse quintal apresenta oito zonas de manejo e a forte característica identificada é a predominância do estrato arbóreo composto por nativas de porte alto, como cedro (Cedrela fissilis), garapubu (Schizolobium parahyba), Figueira (Fícus sp), sombreando o café, fruteiras e ornamentais, além de muitas mudas de palmito. Percebe-se também locais onde predominam espécies frutiferas isoladas. $\mathrm{E}$ um pequeno canteiro de medicinais e condimentares que se encontra próximo à casa. 


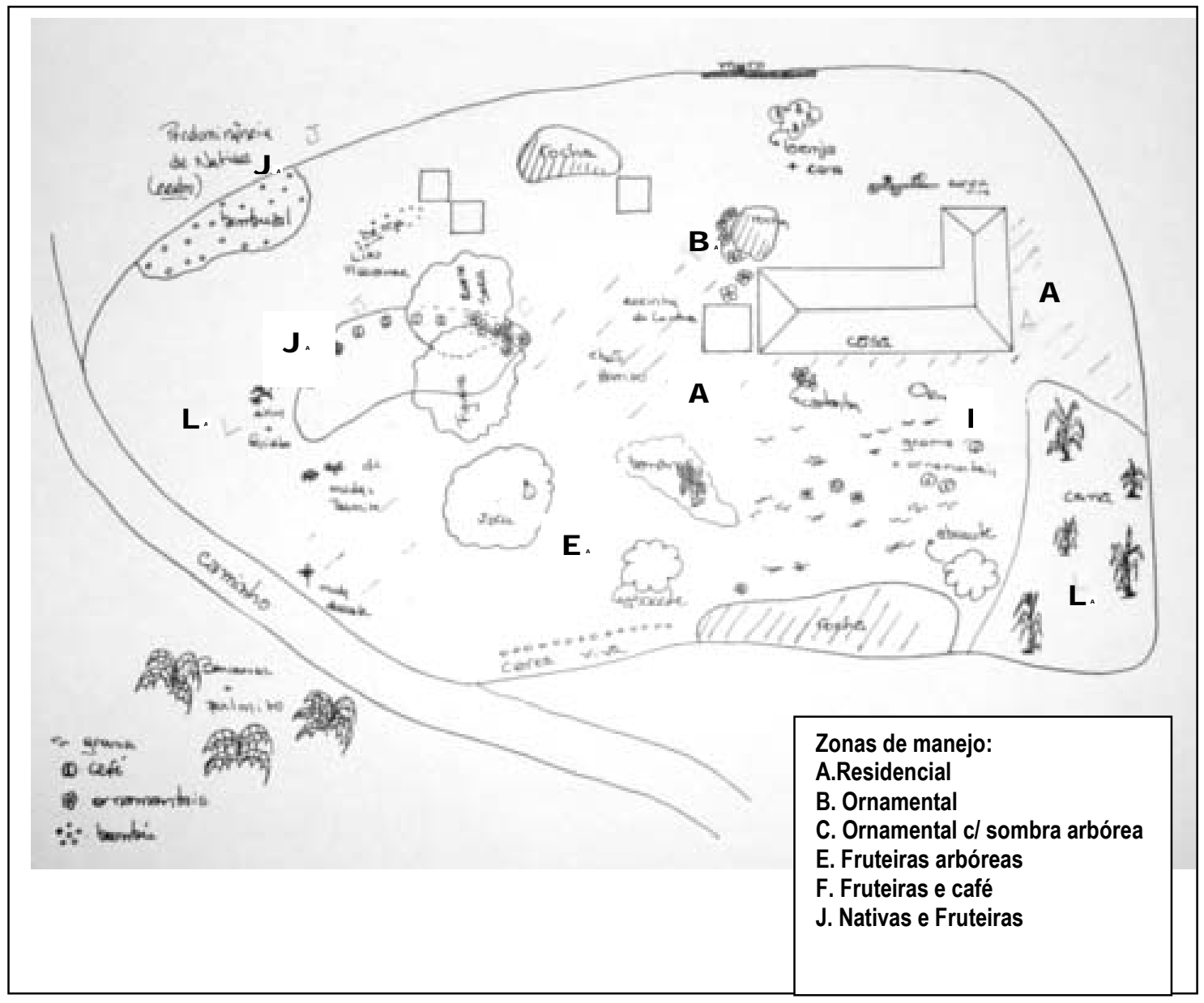

Figura 39 - Croqui da Praia Grande - PG2

Identifiquei seis zonas de manejo nesse quintal e são observadas ornamentais próximas à casa e em uma zona um pouco mais distante, tem-se as ornamentais sombreadas junto com 0 café, por espécies arbóreas nativas. Encontra-se também uma zona destinada aos cultivos anuais, como a cana. E outra onde há o predomínio de fruteiras, como por exemplo o bananal, além de uma área de transição com mata secundária, na qual encontram-se espécies nativas. 


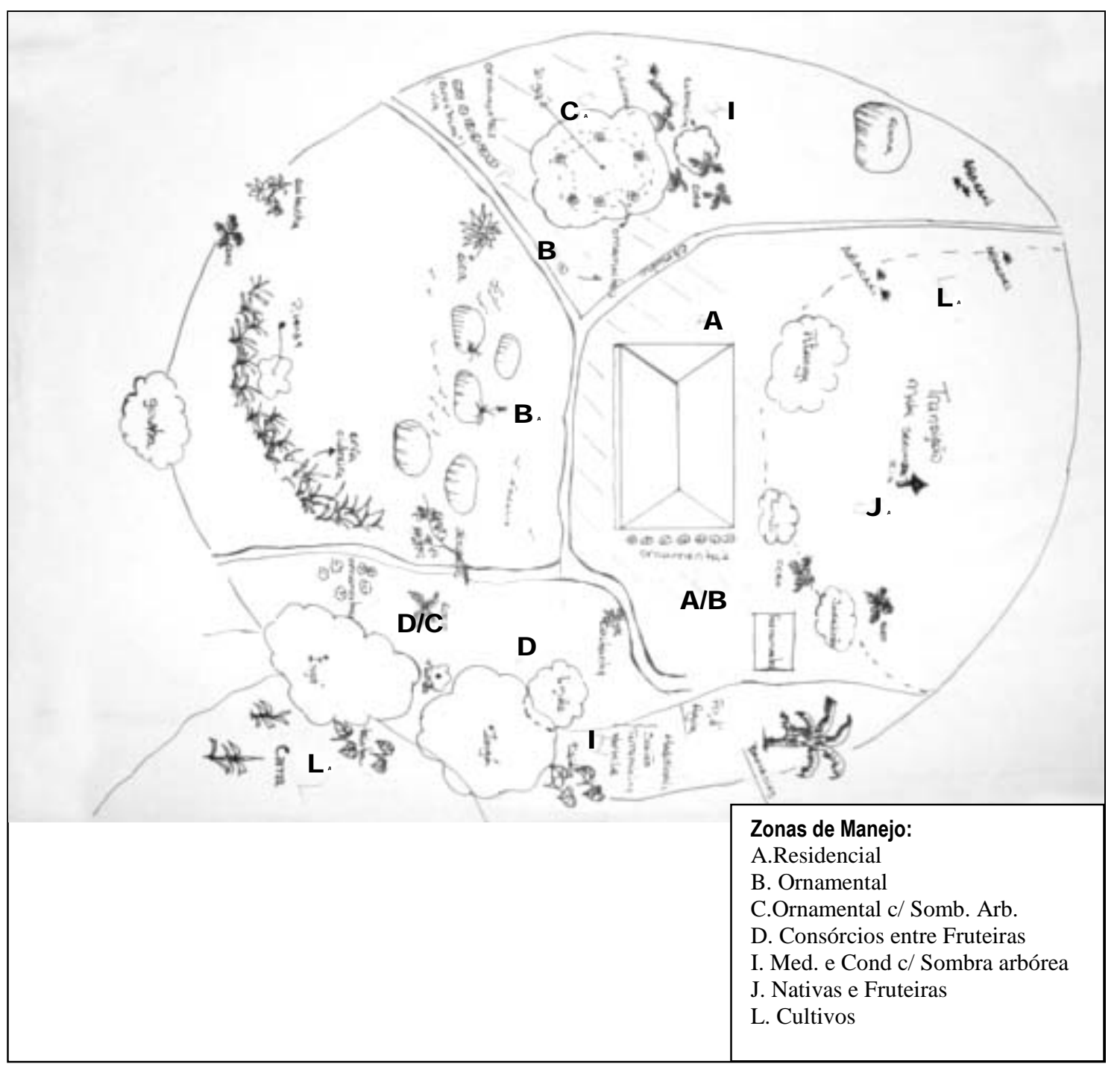

Figura 40 - Croqui do Grupo Familiar da Praia Grande - PG3

Nesse quintal encontram-se seis zonas de manejo, com a predominância de ornamentais junto com espécies medicinais e condimentares ao redor da casa e sombreadas por espécies nativas, também são observadas áreas de cultivos anuais de cana e abacaxi. 


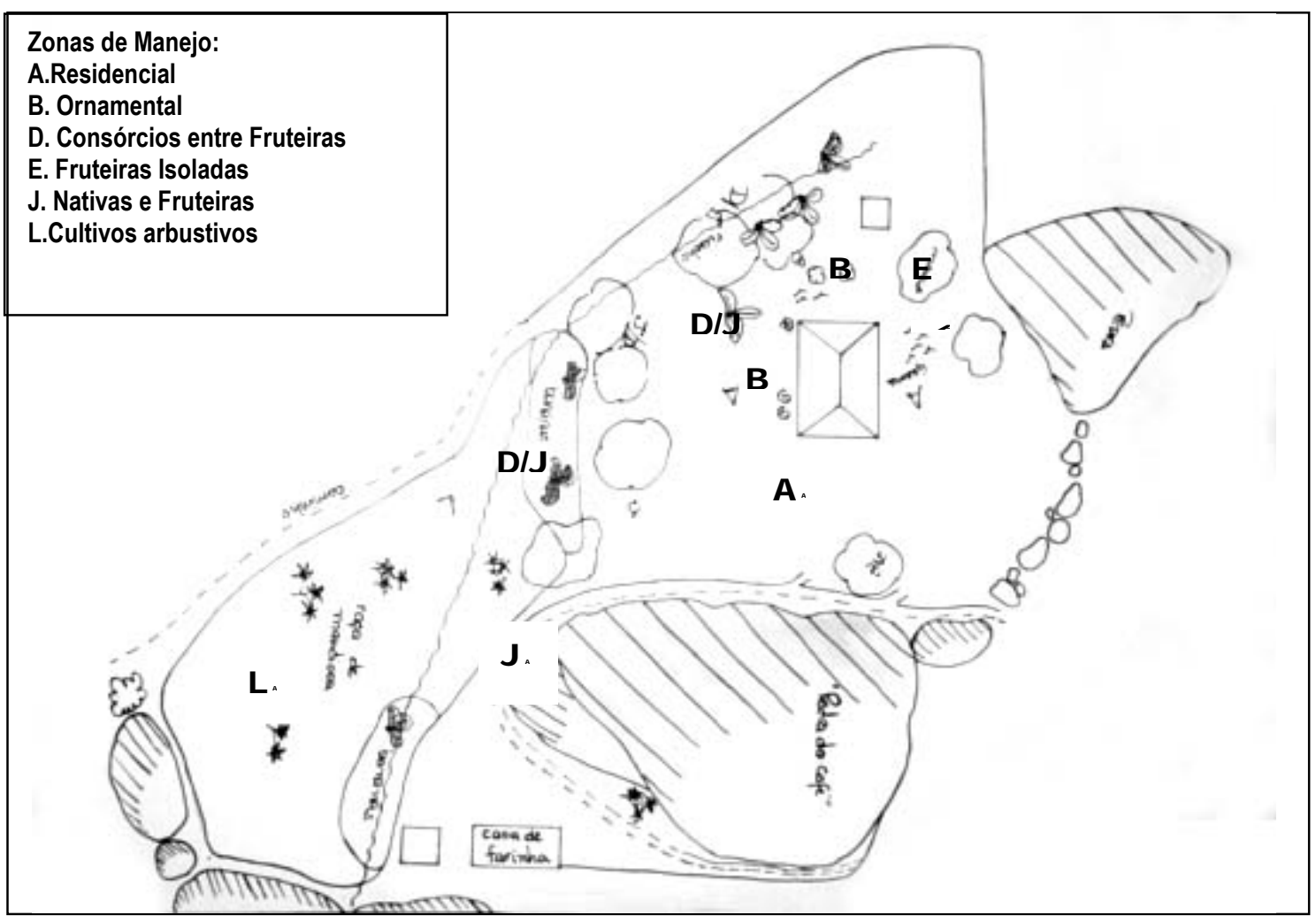

Figura 41 - Croqui do Grupo Familiar da Ponta da Romana, - PR1

Nesse grupo identifiquei cinco zonas de manejo onde predomina o estrato arbóreo com fruteiras e nativas formando consórcios com citrus, bananas, taioba que ocupam o estrato arbustivo, em uma zona intermediária, mais central. Um pouco mais distante da casa tem-se 0 estrato arbóreo que é composto por fruteiras e nativas isoladas. Dando continuidade ao quintal encontra-se $o$ cultivo de mandioca e bananas. 


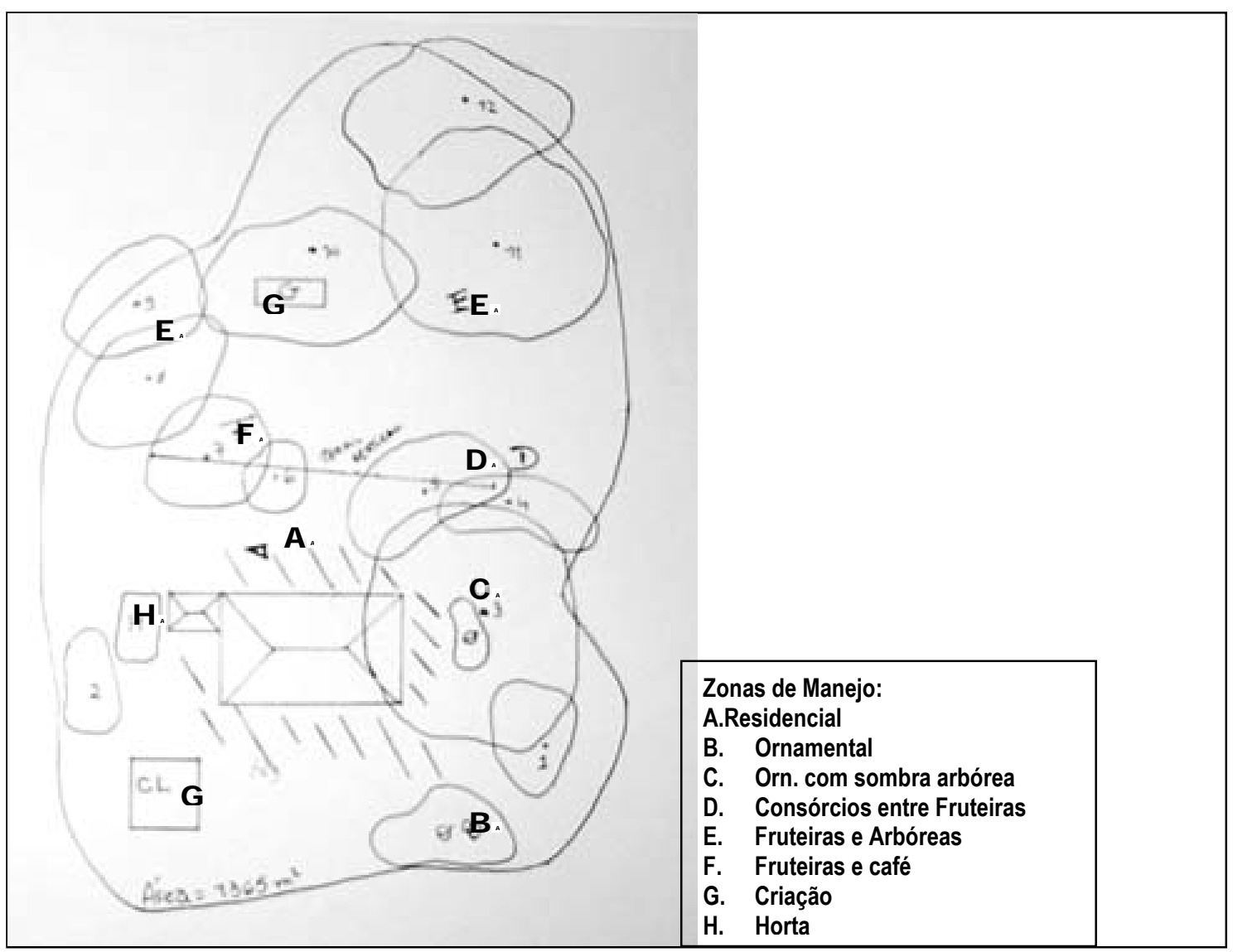

Figura 42 - Croqui do Grupo Familiar da Ponta da Romana - PR2

Sete zonas de manejo são identificadas nesse quintal, mas aqui também há a predominância do estrato arbóreo, com muitas fruteiras compondo este estrato mais alto. Próximo a casa, estão as ornamentais e ornamentais sombreadas por fruteiras. Próxima à cozinha de lenha um pequeno canteiro com medicinais e plantas condimentares. 
- A presença de hortas e animais de criação nos quintais

Os pequenos canteiros, as hortas e animais de criação estão entre os elementos que compõem os quintais. No Saco do Mamanguá dos dezenove grupos familiares estudados, apenas cinco possuem hortas, o que corresponde a $26 \%$ do total. Nesses quintais foram observados pequenos canteiros, nos quais são plantados verduras (alface, couve, chicória) e alguns legumes (pimentão, cenoura, abóbora menina, pepino, quiabo, tomate, tomate gnguito tomate cereja que possui alto valor de mercado) além de medicinais (saião, boldo, erva de santa maria, hortelã) e condimentos (manjericão, salsinha, coentro, hortelã de galinha, coentrão, alfavaca, cebolinha), encontram-se também alguns tubérculos, principalmente a batata-doce. Estes pequenos canteiros enriquecem com verduras e legumes a dieta caiçara, na figura que segue abaixo é possível visuliazar um exemplo de horta presente no quintal do grupo familiar da Praia do Pontal - PP1 (Figura 43). Em outros sete quintais encontram-se os pequenos canteiros nos quais são cultivadas somente medicinais e ou condimentos.

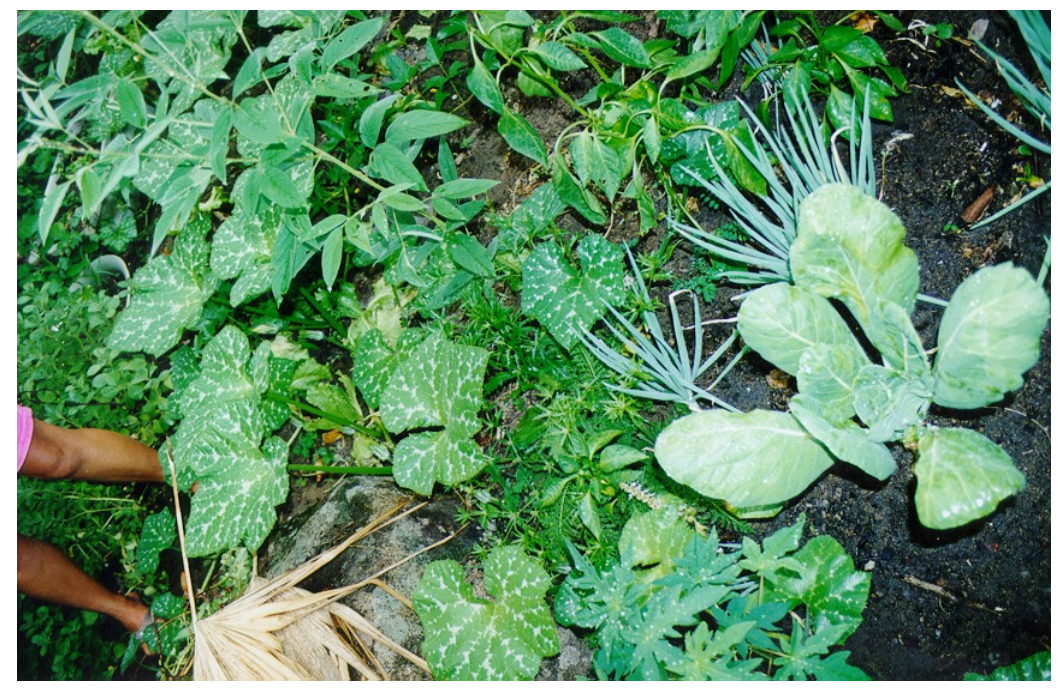

Figura 43 - A horta de um dos quintais estudados - PP1

Contudo, isto não quer dizer que aqueles que não apresentam cultivos de medicinais e condimentares em canteiros específicos, não possuam em seus quintais essas plantas, muitas vezes espalhadas ou em latas e vasos próximas às moradias.

Importante assinalar que o número de hortas nos quintais cresceu a partir da implantação da horta na escola pólo do Curupira. Algumas famílias do Curupira e Regate ganharam mudas na 
escola, que foram distribuídas pela professora, e as plantaram em cercados feitos com rede de pesca e bambu.

A criação animal foi constatada em oito grupos familiares, os quais possuem criação de galinhas e frangos e corresponde a $42 \%$ dos grupos familiares. Em um grupo doméstico cria-se também peru e em um outro um casal de patos.

A criação é destinada principalmente para obtenção de ovos para autoconsumo, mas também pode representar uma pequena fonte de renda quando o excedente é vendido. A produção de ovos e galinhas caipiras do quintal caiçara é um importante componente do quintal, responsável pelo aporte proteíco dos grupos familiares juntamente com a pesca de subsistência e em pequena escala a caça, atualmente pouco praticada entres os grupos familiares estudados. O preço da dúzia de ovos varia entre $R \$ 2,00$ e $R \$ 2,50$. A galinha caipira com $2 \mathrm{Kg}$, aproximadamente, é vendida por $\mathrm{R} \$ 7,00$ a $\mathrm{R} \$ 8,00$. As galinhas em sua maioria são criadas soltas, o que às vezes representa um problema, tanto para quem cria como para os vizinhos, que reclamam que as galinhas acabam com suas plantações. Alguns entrevistados citam este problema como um fator desestimulante para a plantação de hortas e outras ervas.

A alimentação da criação é composta de ração que é comprada na cidade, mandioca (maricá que é "doce" e as galinhas gostam) e milho. Os resíduos (esterco) acumulados nos galinheiros são aproveitados em canteiros, porém não é um hábito em todos os grupos familiares.

\subsubsection{A Presença de Veranistas e seus quintais}

Após caracterizar os quintais caiçaras minuciosamente, abro um parêntese e um contraponto com o que vem de fora, com o diferente, os quintais dos veranistas (Figura 44). Em algumas entrevistas perguntei como eram os quintais dos veranistas com o intuito de saber como se dava a percepção dos moradores locais acerca do outro, partindo de seus próprios referenciais. 


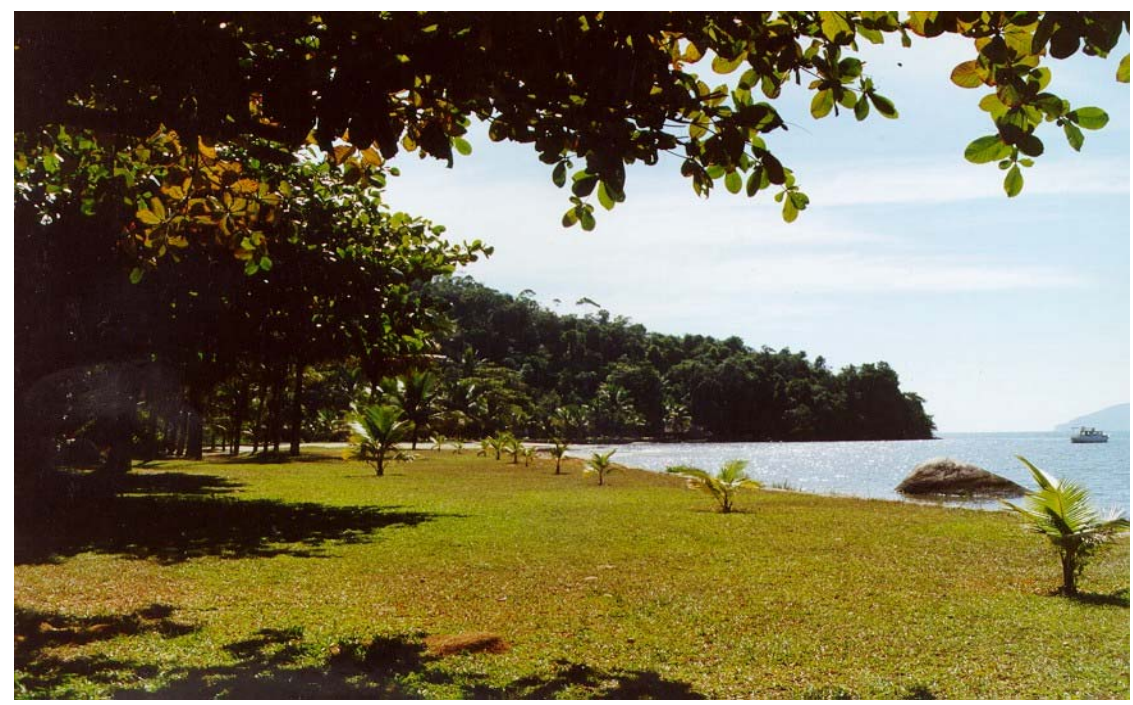

Figura 44 - Exemplo de um quintal não caiçara na Praia Grande, Saco do Mamanguá

Procurei também estar atenta e observar como se dava a interação dos veranistas/proprietários com os moradores locais e como esta se dava em vários níveis. Esta interação é visível ao caminhar/navegar pelo Mamanguá, assim como nas conversas e histórias contadas pelos moradores. E em uma das falas o entrevistado comentava sobre os quintais das pessoas de fora: "Só tem grama, coco e bananas, tem pouca fruteira."

Mas, além dos muitos coqueiros e a grama, observam-se também muitas ornamentais, muitas exóticas e que por vezes "migram" para os quintais caiçaras. E como já citado, outra diferença notável são as cercas, muros e ainda em alguns casos a presença de cachorros ferozes que muitas vezes ameaçam a comunidade.

Porém, é também preciso fazer outra ressalva, que esta não é uma atitude seguida por todos. Existem os veranistas/proprietários que interagem de forma menos impactante ao cotidiano caiçara, tanto com o ambiente que recentemente ocuparam, como com seus habitantes. Isto se reflete por exemplo, na opção por cercas vivas de "mimo" (Hibiscus rosa sinenses), e também em suas construções mais discretas que se perdem em meio à mata. Manifesta-se também através de suas atitudes de respeito e solidariedade para com as pessoas do lugar e sua cultura. Alguns destes proprietários colaboram com a Associação de Moradores, daí o nome da Associação de Moradores e "Amigos" do Mamanguá. A colaboração vai desde a contribuição em dinheiro para realizar a festa anual de Natal, como também em serviços médicos 
e odontológicos, já que estes são extremamente precários no lugar. Alguns veranistas/proprietários já se mobilizaram para defender o lugar de empreendimentos, que com certeza teriam conseqüências sócio-ambientais sérias, que transformariam o lugar e muito se perderia, entre estas perdas, está a beleza natural exuberante do lugar e o sossego, que levaram muitas destas pessoas escolherem o Mamanguá como seu lugar de descanso e refúgio.

\subsection{A Dieta caiçara e o uso dos recursos locais}

Os levantamentos realizados sobre a dieta familiar ofereceram dados para um entendimento geral e atual do uso dos recursos disponíveis a partir da alimentação. Em conjunto aos depoimentos coletados, estes dados complementaram as informações que possibilitaram inferir se as mudanças sócio-ambientais externas mais marcantes e atuais estão de fato atuando sobre as formas de uso da terra e se estas são refletidas nos hábitos alimentares das famílias.

Uma interessante discussão sobre a relação mantida entre o ser humano e o seu meio, pode ser elaborada através da alimentação em seus diferentes aspectos, além da simples abordagem nutricional. Esta discussão é proposta por Oliveira \& Thébaud-Mony (1997) ao considerar os aspectos complementares à análise nutricional, como o econômico, o social e 0 aspecto cultural, onde estes são analisados em seu conjunto, em busca de uma abordagem multidisciplinar. E foi com esta abordagem que verifiquei as mudanças no consumo alimentar como reflexo da dinâmica sócio-econômica e cultural relacionadas aos sistemas de produção e distribuição na comunidade do Saco do Mamanguá.

Os caiçaras têm na roça e nos quintais a base de sua subsistência (juntamente com os pescados), a análise da relação entre o consumo dos produtos advindos desses sistemas e da situação sócio-econômica das famílias, permitiu perceber a complementaridade desses sistemas. As mudanças no contexto sócio-ambiental e econômico podem afetar direta e indiretamente, de forma negativa ou (até mesmo) positiva as comunidades caiçaras. E para realizar a análise da dieta na comunidade do Saco do Mamanguá, parti da mesma premissa considerada por (Hanazaki, 2001, p. 98), a qual coloca que: 
"A relação entre usos de recursos e dieta pode refletir ajustes a situações de mudança. Não raro ocorrem situações de mudança no modo de vida e de subsistência de uma população local que são refletidas na dieta desta população."

E esta autora considera que uma das conseqüências das mudanças observadas, é o que Pelto \& Vargas (1992) chamam de "delocalização alimentar", termo que resume uma série de processos complexos que têm como resultado maior dependência de produtos industrializados em detrimento dos que são produzidos localmente. Fato também observado por Candido (1987) em relação às populações caipiras, no qual o autor cita que tal situação, está relacionada ao desligamento dos meios naturais, a aceleração do ritmo de trabalho e a maior dependência dos centros urbanos. E este fato não poderia deixar de repercutir na esfera cultural, na reelaboração de técnicas, práticas e conceitos.

No caso do Saco do Mamanguá o aumento do poder aquisitivo de algumas famílias,o que está relacionado diretamente ao turismo através das relações de trabalho, pode ser um dos fatores (ente outros já mencionados, como a perda de território para o plantio) que influenciou nos hábitos alimentares de alguns grupos familiares. 0 que observei foi à aquisição de uma porcentagem elevada de alimentos industrializados em suas dietas, comprados na cidade como é demonstrado na tabela que segue abaixo (Tabela 5), em que são apresentados os percentuais dos gêneros alimentares correspondentes as suas origens.

Tabela 5. Origem dos alimentos consumidos na dieta caiçara

\begin{tabular}{cl}
\hline Origem & Porcentagem \% \\
\hline Armazém & 60,2 \\
Roça & 6,2 \\
Quintal & 13,7 \\
Mar & 7,4 \\
Floresta & 4,9 \\
Vizinhos & 7,6 \\
\hline
\end{tabular}


Em uma análise geral dos dezenove grupos familiares, onde quantifiquei os itens alimentares quanto a origem (arrmazém, roça, quintal, mar floresta e vizinhos), mais da metade dos itens presentes no levantamento da dieta são comprados na cidade de Paraty ou em pequenos armazéns na comunidade, representando $60,2 \%$ da dieta. Estes itens constituem em sua grande maioria a base das principais refeições, como, o arroz, feijão, temperos e a farinha de mandioca e nunca estão ausentes das "listas de compras".

Ao realizar o levantamento em duas comunidades caiçaras no litoral sul de São Paulo (Pedrinhas e São Paulo do Bagre), Hanazaki (2001) observou que a farinha de mandioca, apesar de ser um item citado freqüentemente, existiam famílias que abandonaram o hábito de consumila, mesmo sendo um item considerado básico na dieta caiçara.

Nos grupos familiares do Mamanguá a farinha da mandioca ainda é um item presente na dieta e todos os grupos a consomem e quando esta falta, compram na cidade. Esse fato demonstra que o plantio dos roçados já é insuficiente para o abastecimento da comunidade para a farinha de mandioca, o que antes, dificilmente faltava ou se comprava na cidade.

A compra geralmente é mensal, o acesso é difícil e nem todas as famílias possuem geladeira, o que considerei como um dos fatores que também pode influenciar na decisão de compra dos gêneros alimentares e por fim na variedade da dieta familiar. Este elemento, também oferece pistas sobre a situação econômica das famílias.

Mas observa-se também que os recursos locais (mar, floresta, roça e quintal) juntos ainda contribuem com parte significativa da dieta como um todo, com aproximadamente $40 \%$ da alimentação caiçara $(39,8 \%)$. Para os dezenove grupos familiares aqui estudados, $13,7 \%$ dos alimentos são provenientes dos quintais e estão presentes no seu dia-a-dia.

É interessante assinalar que a maioria dos grupos familiares pesquisados mantém relações de parentesco, entre eles e com outros grupos que não são mencionados nesse estudo, são observadas trocas de alimentos e outros bens com certa freqüência. Os grupos familiares que mantém relações de parentesco entre eles são: R1 e R2; C3 e PP3; PP1 e PP2; PB1, PP3, PG3; PR1 e PR2; CZ1 e CZ2; BA1 e BA2. As trocas entre vizinhos corresponde a 7,6\% e este percentual corresponde aos produtos que advém dos quintais (principalmente frutas, ovos e galinhas), da roça (mandioca, aipim) e os pescados. 
A roça participa com $6,2 \%$ na alimentação dos grupos familiares estudados (com a produção de farinha de mandioca, mas também foram citados outros alimentos como: banana, abóbora, pepino, abacaxi, abacate, maracujá, batata doce e cará), enquanto que os alimentos que têm a procedência do "mar" chega a 7,4\%, e contribuem na dieta com os pescados (aqui estão incluindos os mariscos e outros que são coletados na praia, mangue e costeira, além dos diversos peixes, sobretudo o parati) e a floresta com 4,9\%, (caça e farinha de coco pati). Os levantamentos das dietas familiares foram realizados de março de 2001 a fevereiro de 2002, que se deu concomitante aos demais levantamentos em nove viagens a campo. A coleta de muitas informações, aliada às dificuldades logísticas foi determinante na restrição da minha amostra quanto ao levantamento da dieta.

Com os dados que obtive em 208 levantamentos das principais refeições (almoço e jantar) que compõem a dieta familiar, pude observar o predomínio de uma dieta básica entre as famílias nas quais realizei o estudo. Cujo cardápio diário das principais refeições, (que dificilmente é alterado) se mantém praticamente fixo: arroz com feijão e a farinha de mandioca, e o peixe alternando-se com outra fonte proteíca. 0 que pode variar nessa dieta é o acréscimo de outros alimentos, complementando-a com macarrão, principalmente, já os legumes são pouco citados, e a carne (bovina, geralmente costela ou carne seca ou de frango), que depende das condições financeiras em que cada família se encontra.

A fonte protéica alterna-se entre peixe, marisco ou sapinhanguá (nome regional), ovos, siri, sendo que estes normalment provém do próprio local, a carne seca, embutidos (mortadela e salsicha, lingüiça) e o frango são freqüentes nos levantamentos das dietas das famílias, e menos citadas estão as carne de porco e carne de boi fresca, costela e em alguns levantamentos, aparece ainda a carne de caça, principalmente cotia, mas também foi citado tatu e o quati. Além dos produtos derivados do leite como, queijo, requeijão, iogurte e o próprio leite em pó.

As verduras e legumes são citados apenas por alguns grupos familiares (R2, PP1, PB1, CZ1) e que em sua grande maioria são comprados na cidade e aqueles grupos que possuem hortas, complementam o consumo desses itens com a produção local.

Nas demais refeições, desjejum e lanche - 0 café fraco e bem açucarado sempre está presente, acompanhado de biscoitos de água e sal, podendo variar, e com bem menos freqüência com aipim cozido, banana cozida, angu de milho, bolinho de fruta-pão ou aipim, 
farinha de mandioca que se toma misturada com café, bolo de fubá, rosca e, quando se vai à cidade, pão de sal ou francês, e a margarina.

$\mathrm{Na}$ tabela (Tabela 6) que apresento a seguir estão representadas as porcentagens referentes a procedência dos itens alimentares levantados por grupo familiar.

Tabela 6. Porcentagens de origem dos alimentos por grupo familiar

\begin{tabular}{ccccccc}
\hline \multirow{2}{*}{ FF } & \multicolumn{7}{c}{ Porcentagem quanto a origem dos alimentos } \\
& Armazém & Roça & Mar & Vizinhos & Quintal & Floresta \\
\hline R1 & 70,2 & 5,3 & 3,5 & 3,5 & 17,5 & 0,0 \\
R2 & 61,4 & 5,6 & 5,6 & 4,1 & 21,8 & 1,52 \\
C1 & 86,3 & 0,0 & 2,0 & 3,9 & 7,84 & 0,0 \\
C2 & 73,3 & 1,0 & 2,9 & 8,6 & 14,3 & 0,0 \\
C3 & 86,3 & 0,0 & 1,96 & 3,9 & 7,8 & 0,0 \\
PP1 & 78,7 & 6,3 & 3,2 & 0,8 & 11,0 & 0,0 \\
PP2 & 77,1 & 0,0 & 2,08 & 3,1 & 19,8 & 0,0 \\
PP3 & 88,4 & 1,2 & 2,3 & 3,5 & 4,7 & 0,0 \\
PB1 & 69,6 & 0,0 & 4,8 & 13,1 & 12,4 & 0,0 \\
PG1 & 82,35 & 1,2 & 2,4 & 2,4 & 11,8 & 0,0 \\
PG2 & 66,0 & 13,9 & 0,7 & 10,4 & 9,7 & 0,0 \\
PG3 & 66,9 & 5,2 & 4,4 & 10,3 & 12,5 & 0,7 \\
PR1 & 80,3 & 5,6 & 0,0 & 2,8 & 11,3 & 0,0 \\
PR2 & 79,6 & 0,0 & 40,1 & 4,1 & 12,2 & 0,0 \\
CZ1 & 84,1 & 0,0 & 2,4 & 3,7 & 9,8 & \\
CZ2 & 50,0 & 12,1 & 0,0 & 10,6 & 27,3 & 0,0 \\
BA1 & 84,3 & 1,9 & & 13,5 & 0,0 & \\
BA2 & 77,4 & 0,0 & 14,3 & 1,8 & 7,11 & 0,0 \\
BA3 & 76,8 & 0,0 & 14,3 & 1,8 & 7,1 & 0,0 \\
\hline
\end{tabular}

Dando continuidade a apresentação dos dados referentes à dieta dos grupos familiares, observa-se que há uma forte relação de todas as famílias com o centro urbano no aporte dos gêneros alimentares. Contudo, as porcentagens estão indicando apenas a quantidade de 
produtos que são comprados em armazéns ou mercados na cidade, mas em relação à variedade, poucs grupos apresentam produtos mais diversos em suas dietas sendo estes os seguintes: CZ1, PB1, PG1, PG2, PG3, PP1, PP3, R2. E citam o consumo de legumes, leite e seus derivados, enlatados, como molho de toamte, achocolatado e também carnes (bovina e o frango que é bem freqüente nos levantamentos). Destes grupos, quatro estão diretamente envolvidos com atividades ligadas ao turismo, outros três, os responsáveis recebem aposentadoria que é complementada com outras atividades, como a pesca, a roça e o artesanato. Mas todos estes grupos possuem facilidades de transporte e maior contato com a cidade, devido as atividades desenvolvidas pelos responsáveis ou por outros integrantes do grupo familiar.

Os quintais em sua maioria, como já apresentado nos itens anteriores, possuem potencial para o uso alimentar. Contudo, pelo que foi levantado na dieta, sua participação direta no cardápio, ao analisar os grupos separadamente, parece ser tímida diante do que pode ser explorado, chegando a ser nula a citação de alimentos advindos do quintal por um dos grupos familiares. Porém, um fator a ser considerado ao analisar esse resultado, é que nem sempre os moradores listavam os alimentos produzidos nos quintais durante as entrevistas, como vou mencionar a seguir. Ao perceber esta situação tentei contorná-la através de questões mais objetivas a respeito do que o quintal estava produzindo e o que havia sido consumido de frutas e temperos, por exemplo. A confecção dos calendários das fruteiras, também foi uma forma de obter maiores dados sobre a produção do quintal e se esta participava na dieta (Anexo C). Procurei também estar atenta as fruteiras que estavam produzindo, durante as visitas às casas. Os principais produtos advindos dos quintais são as frutas, ovos e em seguida tem-se a produção da horta (que inclui temperos e medicinais), porém apenas cinco terreiros possuem hortas. Esses alimentos são de extrema importância no aporte de vitaminas e minerais.

Os diferentes gêneros alimentares produzidos e coletados localmente, conferem à dieta variedade e qualidade nutricional. Assumem importante papel, pois em geral as famílias têm dificuldades em adquirir tais produtos na cidade, porque estes elevariam os custos com a alimentação no orçamento familiar, que muitas vezes é precário para atender as necessidades da família. Durante todo o ano são observadas frutas nos quintais (Figura 45), principalmente banana e mamão, ver a disponibilidade de frutas e outras plantas observadas durante as visitas aos quintais e também citadas nos calendários (Quadro 6), que segue mais abaixo. Mesmo 
aquelas famílias que não possuem mais plantios ou até mesmo o espaço suficiente para estes, possuem na comunidade relações de trocas e/ou pequenas vendas, que são estabelecidas entre os vizinhos e parentes (principalmente, ovos, tubérculos e frutas, além dos pescados) o que garante de alguma forma o acesso a esses tipos de alimentos. No quadro que segue abaixo procurei reunir os dados obtidos durante as visitas aos quintais, com o preenchimento dos calendários e os levantamentos da dieta.
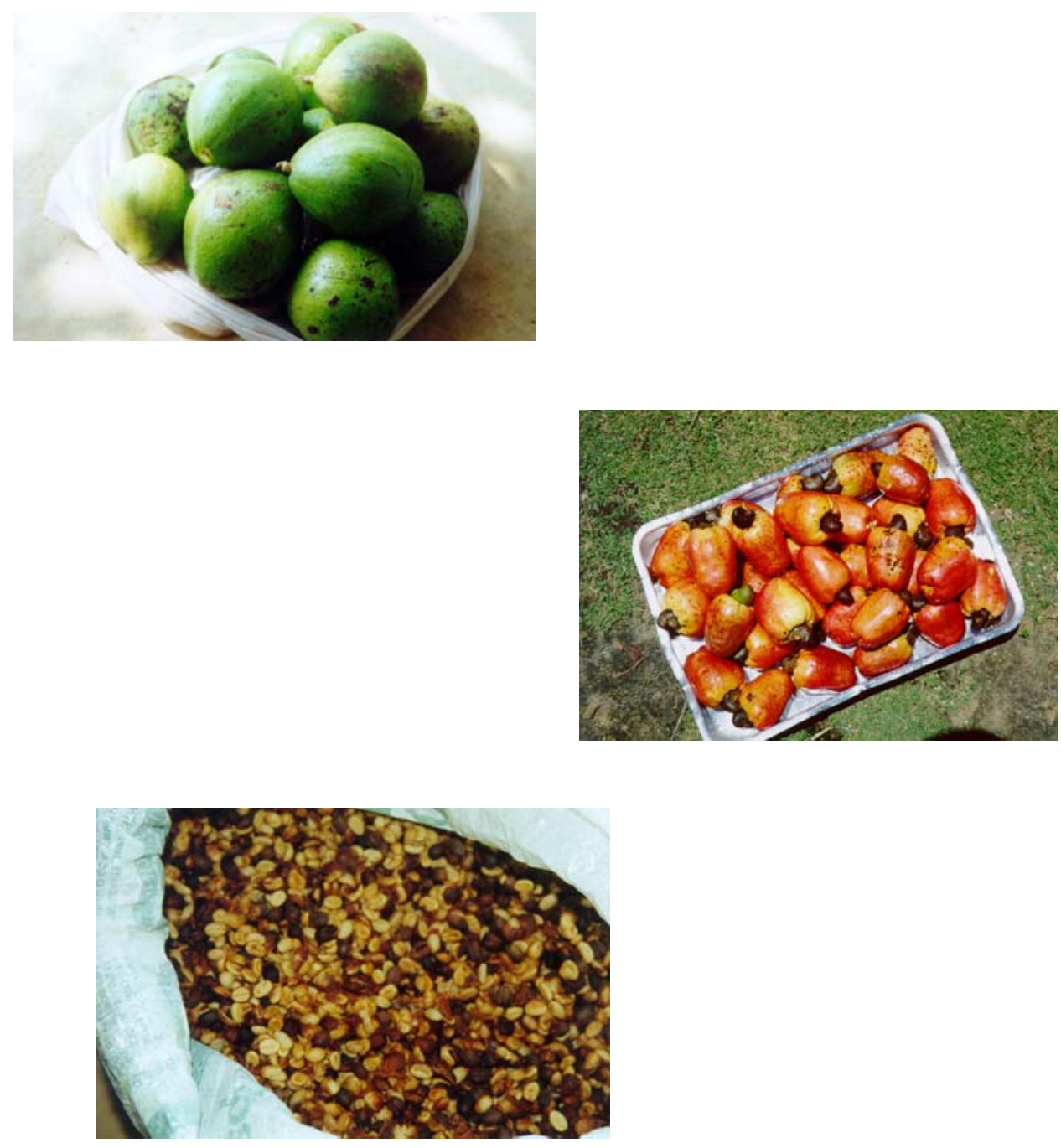

Figura 45 - Podutos que vêm dos quintais (abacate, caju e café) 


\begin{tabular}{|c|c|c|}
\hline Levantamentos & $\begin{array}{l}\text { Alimentos disponíveis (observados nos quintais e citados no } \\
\text { preenchimento do calendário)* }\end{array}$ & $\begin{array}{l}\text { Alimentos produzidos nos quintais citados no levantamento da } \\
\text { dieta familiar** }^{* *}\end{array}$ \\
\hline Mar/01 & $\begin{array}{l}\text { Limão, maracujá, banana (início), abacate (final), laranja, jaca, } \\
\text { café, jambo, urucum, Iranja }\end{array}$ & $\begin{array}{l}\text { abacate, banana da terra, banana prata, batata doce, laranja, limão } \\
\text { cravo, mamão, maracujá }\end{array}$ \\
\hline Abril/Maio/01 & Laranja, limão, abacate, banana, mamão, palmito, jambo, café & $\begin{array}{l}\text { banana prata, maracujá, inhame, condessa, abacate, laranja e limão } \\
\text { cravo, laranja lima, abóbora, banana cinzenta, jambo, laranja cravo, } \\
\text { laranja lima, maracujá }\end{array}$ \\
\hline Jun/01 & $\begin{array}{l}\text { Fava, banana cinzenta, mamão, goiaba branca e vermelha, } \\
\text { manga, banana prata, laranja, café, palmito, jambo }\end{array}$ & $\begin{array}{l}\text { banana prata, maracujá, inhame, condessa, abacate, laranja e limão } \\
\text { cravo, laranja lima, abóbora, banana cinzenta, banana nanica, banana } \\
\text { prata veiaca, fruta pão, laranja, laranja cravo, mamão. }\end{array}$ \\
\hline Ago/01 & $\begin{array}{l}\text { Limão (final), feijão guandu, ata, cacau, banana, limão, urucum, } \\
\text { mamão, condessa, pitanga, romã, coco, ingá, banana cinza, } \\
\text { ameixa, chuchu, jaca e amora }\end{array}$ & $\begin{array}{l}\text { banana prata, coco, tomate gunguito, condessa , laranja, jaca, goiaba } \\
\text { branca, mamão, banana cinzenta, feijão guandu, batata doce, chuchu, } \\
\text { chicória, tomate normal }\end{array}$ \\
\hline Set/Out/01 & $\begin{array}{l}\text { Ata, abacaxi coco, banana prata, limão e condessa, pitanga, } \\
\text { urucum, jaca, pitanga e ameixa (final), fruta-pão, ingá, mamão, } \\
\text { jaboticaba, batata doce, jambo }\end{array}$ & $\begin{array}{l}\text { coco, manga, banana prata, condessa, cana, fruta pão, manga, alface, } \\
\text { ata, batata doce, chicória, couve, goiaba branca, ingá, mamão, } \\
\text { pitanga, tomate normal }\end{array}$ \\
\hline Dez/01 & $\begin{array}{l}\text { Coco, banana prata, algodão, mamão, castanha, jaca, banana da } \\
\text { terra, d'água, manga, cereja, fruta- pão, guandu, amora, cana, } \\
\text { pepino, milho, quiabo, urucum, acerola, café, ingá, abacaxi, } \\
\text { chuchu, jaca, jaboticaba, condessa, romã, jambo }\end{array}$ & $\begin{array}{l}\text { tomate gunguito, banana prata, batata doce, banana terra, chuchu, } \\
\text { alface, cacau, limão cravo. }\end{array}$ \\
\hline Jan/02 & $\begin{array}{l}\text { Grumixama, goiaba, cereja, maracujá, caju, pitanga e banana, } \\
\text { manga, goiaba, coco, limão, jaca, café }\end{array}$ & $\begin{array}{l}\text { chuchu, banana prata, coco, goiaba vermelha, jaca, limão cravo, } \\
\text { mamão, maracujá, tomate gunguito }\end{array}$ \\
\hline Out/Nov 02 & $\begin{array}{l}\text { Abacaxi, laranja, limão, mamão,abacate do amarelo, banana da } \\
\text { terra, banana, condessa, cambuá, coco }\end{array}$ & $\begin{array}{l}\text { laranja china, laranja cravo e limão legítimo, banana da terra, banana } \\
\text { prata, cajá-manga, caju, condessa, fruta pão, jaca, jambo, laranja, } \\
\text { laranja china, laranja cravo, laranja lima, mamão, maracujá }\end{array}$ \\
\hline
\end{tabular}

Quadro 6 - Os alimentos produzidos nos quintais e consumidos na dieta 


\subsubsection{Algumas reflexões sobre as técnicas aplicadas durante o trabalho de campo- Os problemas encontrados e suas adaptações.}

- Recordatório 24 horas

Quando iniciei a aplicação do método Recordatório 24 horas, procurei esclarecer os entrevistados sobre o propósito desse levantamento e sua ligação com o resto do trabalho que estava sendo realizado nos quintais. Mesmo assim, muitas pessoas perguntavam o porquê dos levantamentos e pareciam não entender. A principal dificuldade encontrada por mim, foi a obtenção das quantidades dos gêneros, tanto os comprados como os coletados, nos quintais, roças ou então pescados e etc. Muitas vezes, as pessoas respondiam que não sabiam a quantidade, ou então diziam que era a mesma quantia: "é aquela mesma de sempre..." Por fim, não considerei a quantidade, pois este não era um dado significativo para responder as perguntas propostas e oferecer subsídios para a discussão acerca da importância do quintal

Em determinadas situações este método se configurou invasivo para as pessoas entrevistadas. Muitas pessoas ficavam sem jeito, pela simplicidade do seu alimento, por se repetirem os mesmos gêneros em várias refeições, ou até mesmo pela falta destes ${ }^{28}$. Nessas situações é preciso considerar também o entrevistador, muitas vezes me vi em situações desconfortáveis e senti que estava de fato invadindo a privacidade das pessoas entrevistadas.

Outra observação feita durante a aplicação da técnica, era que a maior parte dos gêneros alimentares produzidos nos quintais é frutas e dificilmente as pessoas lembravam de citá-las durante o Recordatório 24 horas. Contudo, as frutas são consumidas durante todo 0 dia, algumas vezes direto e embaixo "do pé", principalmente pelas crianças (Figura 42). Para contornar esse problema, durante as entrevistas se enfatizou as perguntas sobre as frutas, verificou-se as fruteiras que estavam produzindo e se já estavam maduras ou "de vez", "deveizando". Perguntava também se não haviam feito trocas de outros produtos entre vizinhos ou parentes, como ovos, aipim, banana, etc.

\footnotetext{
${ }^{28}$ Essa situação é decorrente das poucas opções existentes atualmente para a maioria das famílias que sofrem com a falta de alimentos (plantios escassos ou inexistentes) e o acesso à cidade é difícil, ou ainda há falta de dinheiro para compra de alimentos.
} 


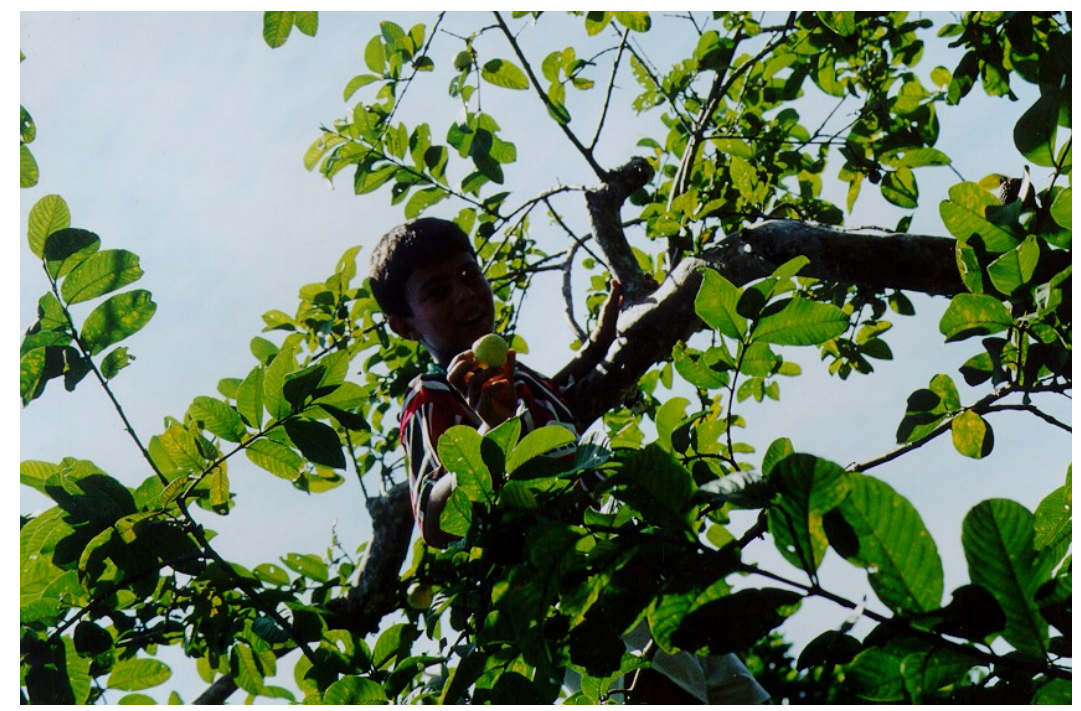

Figura 42 - "Brincadeira com gosto de goiaba"

\section{- Calendários das Fruteiras}

Este instrumento foi elaborado com a intenção de completar as informações sobre as fruteiras em especial quanto à sazonalidade e 0 aproveitamento das frutas produzidas nos quintais. A utilização desse instrumento ficou aquém das minhas expectativas, esperava um pouco mais de envolvimento das pessoas com o calendário. Todos os calendários, no entanto, ao serem recolhidos encontravam-se preenchidos, alguns incompletos e outros com mais detalhes, mais completos. Observei que os dados sobre fenologia não haviam sido acompanhados como o desejado por parte dos responsáveis. Já o aspecto positivo relatado pelas pessoas foi o preenchimento de seus calendários junto com vizinhos, com amigas (os), ou com os filhos. $O$ calendário propiciou a participação espontânea de outras pessoas, além das que se dispuseram realizar o preenchimento. Isto foi importante para tirar as dúvidas ao completarem os dados e a checagem das informações que estavam registrando. Com isso acredito de ter atingido parte dos objetivos, de alguma forma chamei a atenção para as fruteiras de seus quintais.

Outro ponto positivo foi a proposta de envolvimento dos alunos com os calendários das fruteiras, pensada em conjunto com os professores da escola pólo do Mamanguá. A proposta inicial era trabalhar apenas com os grupos familiares, mas sempre tive em mente envolver de 
alguma forma a escola da comunidade. Assim que o calendário ficou pronto, achei que esta seria uma boa forma de aproximação. Com isso, apresentei meu trabalho e este instrumento à Secretaria Municipal de Educação de Paraty e aos professores da escola pólo do Mamanguá. Propus que fossem desenvolvidas atividades com as crianças a partir dos calendários, por acreditar que este poderia ser utilizado como instrumento didático. Ao apresentar o calendário aos professores, pensamos em temas e formas de trabalhar com esse instrumento em grupos ou individualmente. Coloco a seguir algumas idéias iniciais de atividades pensadas com três professores do Mamanguá:

Tema: Conhecendo as fruteiras do quintal-

Cada grupo escolheria uma ou mais fruteiras de seus quintais e assim desenvolveriam as seguintes atividades:

- Os tipos de flores, as épocas de floração e frutificação

- Os insetos e os pássaros que visitam as fruteiras dos quintais

- As frutas e a alimentação

- As frutas e os remédios

Tema: Sentindo os sabores do Quintal

- Os tipos de fruteiras e as receitas conhecidas e as que podem ser inventada Tema: Aspectos nutricionais e a merenda escolar

- Que plantas queremos plantar?

- O que gostaríamos de ter em nossa merenda?

- O que o quintal da escola pode nos dar?

- O quintal da escola, quem vai cuidar?

Sugeri também que as atividades fossem trabalhadas também com poesias e músicas que em suas letras falassem de frutas e quintais. 


\subsubsection{Um pouquinho do sabor dos produtos que vem do quintal}

Durante as vistas às famílias, degustei e coletei algumas receitas que utilizam os produtos dos quintais (e das roças).

Fruta-pão: come-se cozida com o café, mas também se faz bolinho, recheado com carne moída, marisco, camarão ou queijo.

Aipim: come-se cozido com o café, e da mesma forma que a fruta-pão, se faz bolinho, recheado com carne moída, marisco, camarão ou queijo.

Coco: pode-se fazer a cocada, além do cuscuz de coco com tapioca e com fubá.

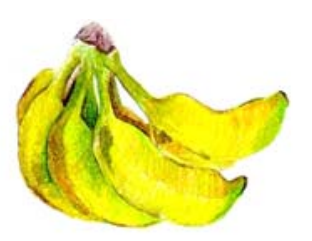

Banana de São Tomé: com esse tipo de banana é feito um prato típico da região e do Mamanguá, chamado "Azul Marinho". Além de ser hábito cozinhar todos os tipos de bananas para comer com o café.

Urucum: é usado para fazer o colorau, tempero muito usado na região, principalmente para substituir molho de tomate e é usado no macarrão.

Mamão, Limão, Laranja: são feitos doces em compota com essas frutas.

Pitanga: é usada para sucos e geléia e também como remédio.

Cana: todos citam a época em que as pessoas eram criadas com "café de cana", não existia o açúcar e se passava o café com o caldo de cana. Citam o melado e as balas "puxa-puxa".

Batata-doce: faz- se bolo cremoso e come-se cozida com o café.

São também citadas as plantas para remédio como o saião e a embaúba branca usadas para fazer xarope, erva de santa maria para fazer chá para vermes, boldo para o fígado, terramicina usada para infecções, entre outras. Os principais condimentos citados e presentes nos quintais são: alfavaca; hortelã de galinha; coentrão, salsinha e manjericão. Usados para temperar marisco, siri, peixes, carne e frango ou galinhado "caipira". 


\section{CONSIDERAÇÕES FINAIS}

As informações e dados obtidos nos levantamentos de campo desta dissertação apontam uma série de mudanças significativas que ocorreram no uso da terra na comunidade do Saco do Mamanguá nas últimas décadas, sobretudo, após a abertura da Rio-Santos a qual atingiu diversas comunidades caiçaras. Essas mudanças ocorreram de forma gradativa no Saco do Mamanguá, devido ao difícil acesso, porém a venda das terras e a inclusão de novas atividades ligadas ao turismo, refletiram no comportamento dessa população, que hoje, são mais visíveis nos jovens, os quais perderam a tradição agrícola e se interessam apenas por atividades remuneradas e ligadas ao turismo.

Com a venda de suas posses próximas ao mar, o caiçara perde parte da possibilidade concreta de produzir e reproduzir sua cultura. Sem o seu território à beira-mar, os moradores locais se deslocam para as encostas, diminuindo, assim, o espaço de mobilidade interna das famílias e os espaços de cultivos, tanto da roça, quanto dos próprios quintais.

A comunidade do Mamanguá vivencia hoje uma conjuntura de crise revelada nos meios de subsistência, nas formas de organização e nas concepções de mundo diante das pressões sócio-ambientais. Crise esta que condiciona alterações nos padrões culturais tradicionais, podendo levar ao seu desaparecimento ou a persistência destes. As famílias que ainda possuem seus quintais e roçados produtivos manifestam, de certa forma, elementos de persistência do modo de vida "antigo" dentro desse contexto. Exemplo disso são os cultivos presentes, os tipos de manejo praticados, o uso dos recursos locais e as benfeitorias, como as casas de farinha que ainda persistem em alguns quintais. Esses elementos de persistência podem significar reajustes às novas condições e sua readaptação (Cândido, 1987). 
O quintal é composto e modelado por seus moradores com base nas suas necessidades e escolhas. Não é um ecossistema natural e sim um sistema construído pelas pessoas que vivem nele. Portanto, trata-se de um "espaço cultural e dependente das variações do meio social e ambiental", (Lok, 1998b). A perda de território e a substituição parcial ou total das atividades ligadas às práticas tradicionais de subsistência, com a inclusão da safra do turismo no calendário de atividades caiçaras, somadas ao aumento do poder aquisitivo são os aspectos que gradativamente influenciam no uso e na forma do quintal.

Embora, em todos os quintais estudados tenha sido verificada a presença dos principais estratos, confirmando uma de suas principais características, a diferença encontrada entre os quintais estudados, é a diversidade de espécies presentes relacionadas aos estratos e às categorias de uso que os compõem, assim como a proporção entre nativas e cultivadas. Em geral, são os quintais maiores e médios, com maior diversidade em riqueza de espécies e onde se encontra maior oferta de produtos em diferentes épocas do ano, assim como a presença de muitas espécies nativas no estrato arbóreo. E os responsáveis por estes quintais são, em geral, as pessoas mais velhas, cujos vínculos com o turismo são indiretos ou mesmo ausentes. Em todos os quintais é observado, entre outros aspectos, o potencial de uso para alimentação que constitui em um importante papel de complementação da dieta, conferindo aumento na variedade e da qualidade nutricional, porém ao analisar a dieta e a origem dos alimentos, percebeu-se que, em alguns grupos, os quintais contribuem muito pouco para a alimentação das famílias, em detrimento dos produtos que advém dos armazéns. Essa situação reflete o processo de desuso dos quintais por motivos sócio-econômicos e culturais.

Este processo de desuso faz com que as famílias percam uma de suas mais importantes estratégias de sobrevivência, além da perda da diversidade, já que os quintais integram sistemas de modo sustentável e apropriado às características dos ecossistemas (Guimarães, 1998; Pacheco, 1996; Viana; Dubois; Anderson, 1996). Tal situação também foi constatada por Brandão (1981) em que a forma e função dos quintais são modificadas e adequadas às novas exigências sociais e econômicas, principalmente no que se refere ao trabalho assalariado, causando rompimentos com antigos valores e a aquisição de novos. Nessa lógica, os quintais deixam de ser prioridade, os hábitos alimentares são modificados e os integrantes dos grupos familiares empenham-se em ganhar dinheiro para consumir bens de consumo, os quais, muitas 
vezes, já foram produzidos no próprio quintal, sendo esta característica de situações de delocalização alimentar.

A presença e manutenção dos quintais pelos grupos familiares possuem outros sentidos, não apenas aqueles mencionados acima, mas de espaços ocupados de diferentes formas que, inclusive, traduzem diferentes zonas de manejo e oferecem pistas para identificar quem os manejam e suas preferências. Possuem também valores não tão facilmente mensuráveis, mas que conferem às famílias qualidade de vida. Essa afirmação pode ser fundamentada nos dados apresentados nesta dissertação, quando se verifica, por exemplo, a porcentagem da riqueza de espécies que compõe o estrato herbáceo, representado em sua grande maioria pelas espécies ornamentais, seguidas das plantas medicinais. Esses dados revelam um espaço de manejo feminino, ligado à estética e ao bem-estar, contrapondo-se a um olhar puramente utilitário.

Outro aspecto relevante desse sistema de produção é aquele ligado às práticas agroecológicas, já que um quintal bem desenvolvido e produtivo é uma imitação da floresta, devido a sua forma e funções desempenhadas, com a presença de muitos consórcios entre espécies frutíferas, nativas e outros cultivos anuais, além das diferentes zonas de manejo. Essas características propiciam reflexões sobre o uso da terra e o manejo no espaço e no tempo dentro de uma perspectiva histórica e social, dando relevância às opções e aos conhecimentos de cada morador. Em alguns quintais foi possível reconhecer zonas de transição com a mata secundária, com a presença de fruteiras e nativas no estrato arbóreo. A presença de um número significativo de nativas, principalmente, no estrato arbóreo representa uma característica dos quintais do Saco do Mamanguá.

Por fim, pretende-se que os resultados desta dissertação possam, no futuro, subsidiar e incentivar a adoção de práticas agroflorestais adequadas às situações específicas dos quintais, com a perspectiva da retomada da auto-suficiência das famílias do Saco do Mamanguá, como também de outras alternativas de uso da terra, que possam garantir a oferta de diferentes produtos ao longo do ano e que sejam mais condizentes com a situação sócio-ambiental desta comunidade, e com a vocação florestal dessa região, considerando sua condição de remanescente da Floresta Atlântica. 
ANEXOS 
ANEXO A -TEXTO DE APRESENTAÇÃO DO TRABALHO À COMUNIDADE

Esse texto foi apresentado à Associação dos Moradores e Amigos do Mamanguá e aos professores das (antigas) três escolas de ensino fundamental da comunidade.

\section{Apresentação do Projeto de trabalho à Comunidade do Saco do Mamanguá.}

Responsável: Valquíria Garrote 29

\section{“OS QUINTAIS CAIÇARAS, SUAS CARACTERÍSTICAS SÓCIO- AMBIENTAIS E PERSPECTIVAS PARA A COMUNIDADE DO SACO DO MAMANGUÁ, PARATY- RJ”.}

-"Nossa que nome complicado e grande!! É do jeito que esse povo da Universidade gosta..."

- $\quad$ "Mas por que se estuda quintal"?

- $\quad$ "E por que aqui no nosso lugar? O que tem de especial"?

- É... então vou tentar falar um pouquinho sobre este trabalho que estou propondo desenvolver aqui no Saco do Mamanguá.

"Com certeza estas e muitas outras perguntas devem estar passando pela cabeça das muitas pessoas com quem tenho falado ultimamente e tentado explicar sobre a pesquisa que vou desenvolver aqui no Saco do Mamanguá. Além de tentar explicar, convidei algumas famílias a participarem deste trabalho.

Espero que aos poucos as pessoas entendam e se envolvam, percebam que este trabalho não será somente para mim ou para a Universidade, e com o passar de tempo, poderemos descobrir muitas coisas juntos(as), para cada um de nós, nossas famílias e nossa comunidade. E estas descobertas estão mais perto do que imaginávamos, aqui bem do lado, no terreiro, no Quintal...

Então quais serão as expectativas de cada família em relação a este trabalho com os quintais?

E por que estudam quintais?? 
Pois é, no mundo inteiro os quintais são estudados... Os quintais são parte dos sistemas de produção de uma família, têm um papel muto importante na alimentação, muitas vezes também é no quintal que se desenvolvem outros trabalhos como o artesanato, é onde se faz a farinha, ou se conserta a canoa e o peixe e tantos outros afazeres...

É ainda neste espaço tão especial que se criam os animais, as plantinhas que curam e embelezam o lugar com suas flores... É neste espaço que crescem as crianças e que ao findar da tarde podemos sentar e descansar, receber amigos que às vezes vêm de longe. É neste lugar, continuação da casa, que a vida passa e se completa. Por isto que falamos do quintal como um espaço "Sócio- Ambiental".

Vou estudar os quintais... 0 que tem em seus quintais, se o quintal é realmente importante para as famílias do lugar, se tem as plantas que curam e para quê são usadas. Tem muita gente nova que e já não sabe mais sobre estas plantas, perdeu o interesse ou nunca teve ninguém pra explicar, mostrar como faz, como prepara a terra, onde tem muda, ou se é de semente que se planta? E pra que serve? E quanto conhecimento se tem guardado por aí...

A partir do quintal, que surpresa! A gente pode chegar na Floresta... Em uma das Florestas mais importantes do mundo: a Floresta Atlântica... E é neste lugar tão especial que vocês moram e de repente poderemos descobrir coisas juntos.

Vou trabalhar com aproximadamente 15 familias... Pode ser um pouquinho mais. Vou trabalhar com algumas famílias do Cruzeiro, do Baixio, do Pontal, da Praia Grande, Do Curupira, do Regato e da Ponta da Romana.

\section{O Trabalho...}

Tem pesquisa de todo jeito... Pesquisa de Laboratório, pesquisa com gente, tem pesquisa que só trabalha com bicho ou só com planta, com a terra ou com a água, com os peixes, tem pesquisa de todo o jeito...

$O$ tipo de pesquisa que eu vou fazer, trabalha com gente e com planta e um pouquinho com os bichos.... Claro, no quintal é onde as famílias estão, plantando e criando seus animais,

${ }^{29}$ Bióloga, estudante de pós graduação da Universidade de São Paulo, Laboratório de Silvicultura Tropical- Campus de Piracicaba/SP. 
sem falar nas visitas de alguns bichos da mata. Mas o mais importante, é que nesta pesquisa vou coletar dados, informações, que depois serão apresentados às famílias de uma forma simples, criativa e gostosa de discutir.

Trocar e aprender, esta é minha proposta... E é nesta parte do trabalho que vou contar com a participação de cada um. Vou tentar de alguma forma envolver as crianças e suas atividades da escola. É isto mesmo... as crianças podem aprender muito nos quintais.

Para realizar o trabalho, eu pensei em dividir em algumas etapas que serão cumpridas ao longo de mais ou menos um ano e meio...

\section{Etapa}

Convite às famílias apresentação do trabalho, visitas aos quintais;

\section{$\underline{2^{0} \text { Etapa }}$}

Coleta das plantas e conversas sobre o quintal, a família as atividades e o lugar, etc;

\section{Etapa}

Discussão dos dados e sonhar o futuro.

Em cada etapa vou conversar muito com todos, anotar as histórias e os saberes de cada um... Outra informação importante é sobre alimentação, quais são os hábitos, de onde vêm os alimentos que são consumidos diariamente, as dificuldades, as vontades, as receitas. $O$ que se usa, o que se usava e por que hoje não se usa mais. Então é isto, espero que tenha começado a responder as primeiras perguntas e a esclarecer um pouco mais sobre minha presença tão próxima nestes meses que se seguirão, espero que possamos fazer um bom trabalho e que 0 resultado seja gratificante para todos nós, que seremos parceiros e temos muito o que aprender juntos nesta vida."

\section{Obrigada pela atenção e carinho,}

\section{Valquíria*}


ANEXO B - ROTEIROS PARA AS ENTREVISTAS SEMI-ESTRUTURADAS

GUIA PARA O LEVANTAMENTO ETNOBOTÂNICO

\section{Identificação do núcleo familiar}

Nome Comum da planta

Arbóreas: Nativas Cultivadas ( ) Exóticas ( )

Não- Arbóreas: Nativas Cultivadas ( ) Exóticas ( )

Outros

Observação da Fenologia: Floração (meses) / Frutificação (meses)

Para que usa/ Que parte da planta usa

Quem plantou/ Para que plantou?

Forma consórcio? Com quais plantas?

Quem cuida?

Observar o aproveitamento - É constante? Como usa? (in natura ou elaborado)

Verificar Receitas

Altura/ Cor da flor

presença de látex S( ) N ( )

Textura da Folha /Características Especiais

\section{GUIA PARA LEVANTAMENTO DE CRIAÇÃO ANIMAL NOS QUINTAIS}

\section{Identificação do núcleo familiar:}

\section{Tem criação no quintal?}

Tipo de criação

Quantidade

Finalidade

Sistema de produção

Alimentação

Usa os resíduos/ Para quê? 
GUIA PARA O LEVANTAMENTO SÓCIO-AMBIENTAL

\section{Identificação do núcleo familiar \\ Informações do Núcleo Familiar}

Integrantes da Família:

Número de Filhos:

Outros Tipo de Parentesco

Nível de instrução dos integrantes da família

Principais atividades desenvolvidas pelos responsáveis do grupo familiar

\section{Dados da Propriedade:}

Área total da propriedade e/ou do Quintal

\section{Forma de apropriação da terra:}

1 Proprietário; 2 Posseiro; 3 Arrendatário; 4 Caseiro; 5 Outros

Tipo de Habitação

Como se encontra o esgoto: Fossa negra ( ) Fossa Séptica ( ) Não Possui ( )

0 que faz com o lixo/ Considera o lixo um problema?

lluminação/Geladeira

Histórico da Propriedade (ênfase ao quintal, ao espaço próximo à casa)

Localização: Há Quanto tempo mora aqui?

Como era aqui quando a família chegou

Havia floresta? Capoeira? Ou alguma plantação (Qual)?

Onde era a casa? No mesmo lugar ( ) Local diferente ( ) Por que mudou?

\section{Manejo do Quintal}

Como denomina o espaço próximo à casa?

Quem cuida do quintal

Plantio de árvores solteiras (principalmente frutíferas) próximo à casa? Quais?

Plantio de árvores consorciadas (principalmente frutíferas) próximo à casa? Quais?

Observação de Cultivos Anuais/Outros Cultivos

Onde se consegue o material para plantio? 
Foram plantadas espécies que não deram certo? Quais ? Por que não deu certo?

Quantas horas de trabalho são gastas diariamente no quintal?

Quais plantas que dão certo quando plantadas juntas e quais não dão certo?

Quando por algum motivo uma espécie que foi plantada morre, é feito o replantio?

Existem árvores ou plantas que nasceram espontaneamente? Quais?

0 que está faltando em seu quintal?

\section{Manejo da Floresta}

É costume extrair produtos da Floresta? Quais?

Quais as principais espécies madeireiras conhecidas e utilizadas?

Quais as principais espécies não- madeireiras conhecidas e utilizadas?

Quais espécies gostaria de ter em seu quintal? Por quê?

\section{Para finalizar...}

Em relação à história do lugar o que mudou e por que mudou? Tem vontade de se mudar do lugar? Por quê?

Tem projetos/sonhos futuros? Quais são? 
ANEXO C - CALENDÁRIOS DAS FRUTEIRAS

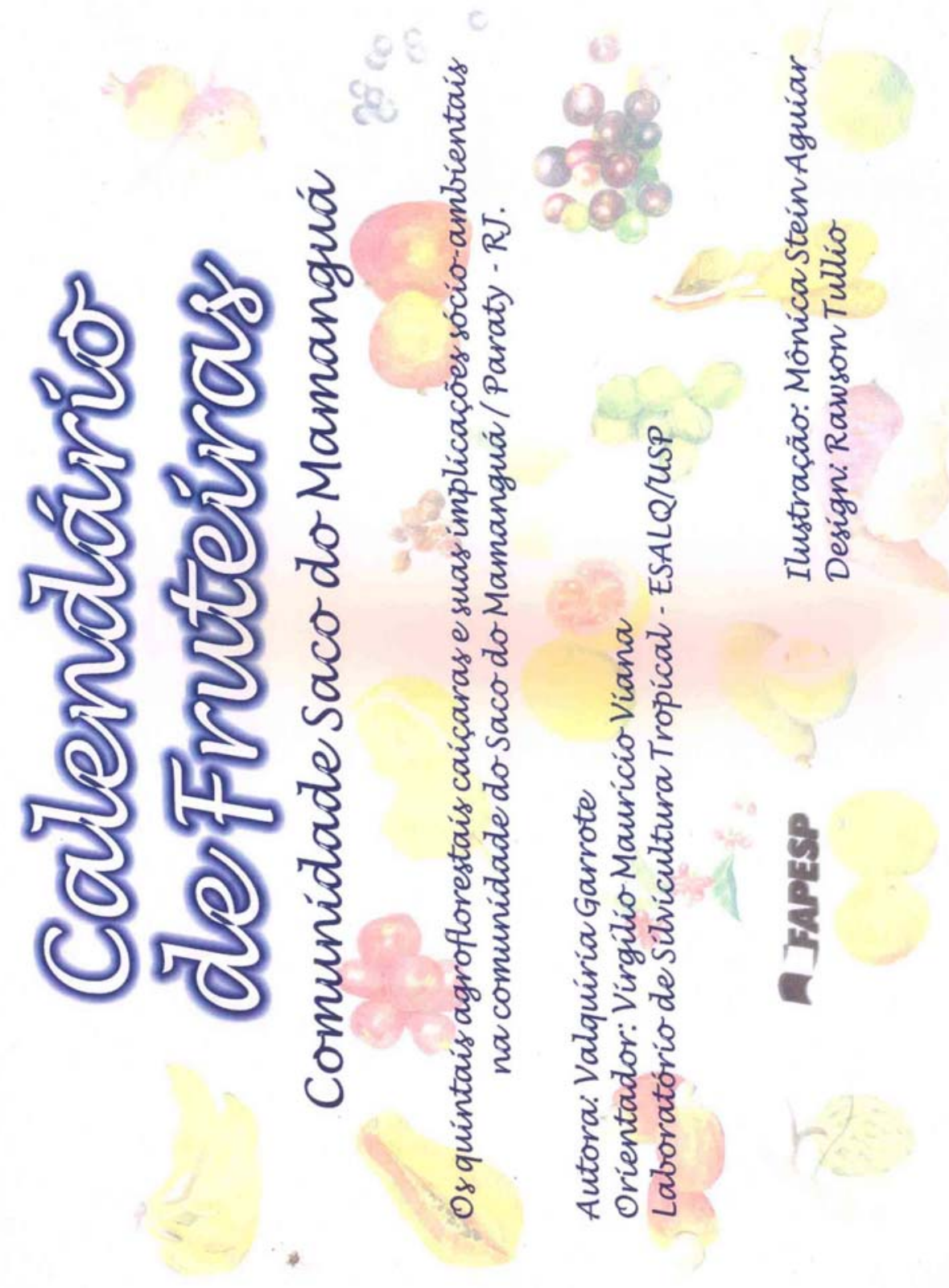


ANEXO C CALENDÁRIO FRUTEIRAS - EXEMPLO PREENCHIDO

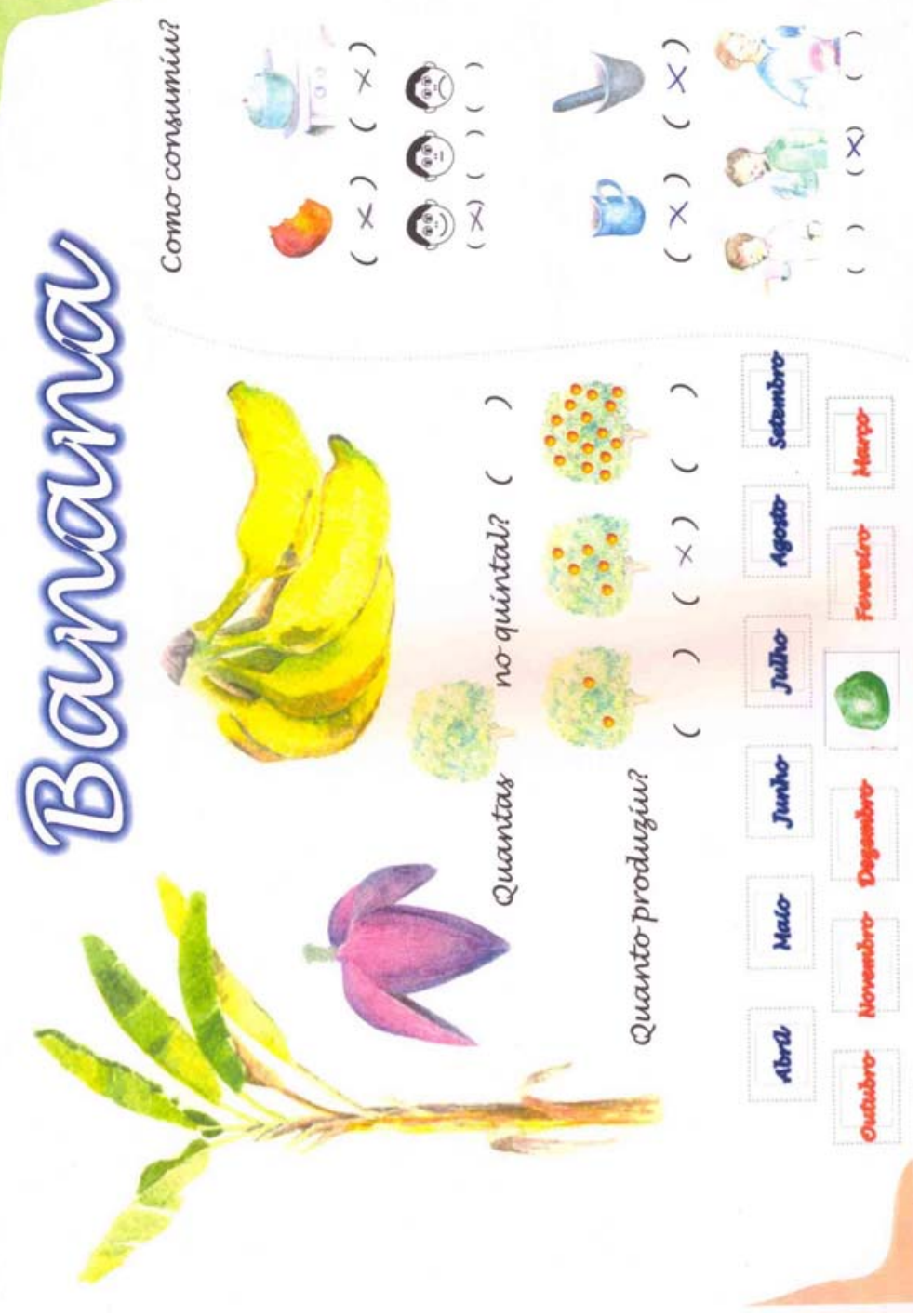


ANEXO C CALENDÁRIO FRUTEIRAS- EXEMPLO PREENCHIDO

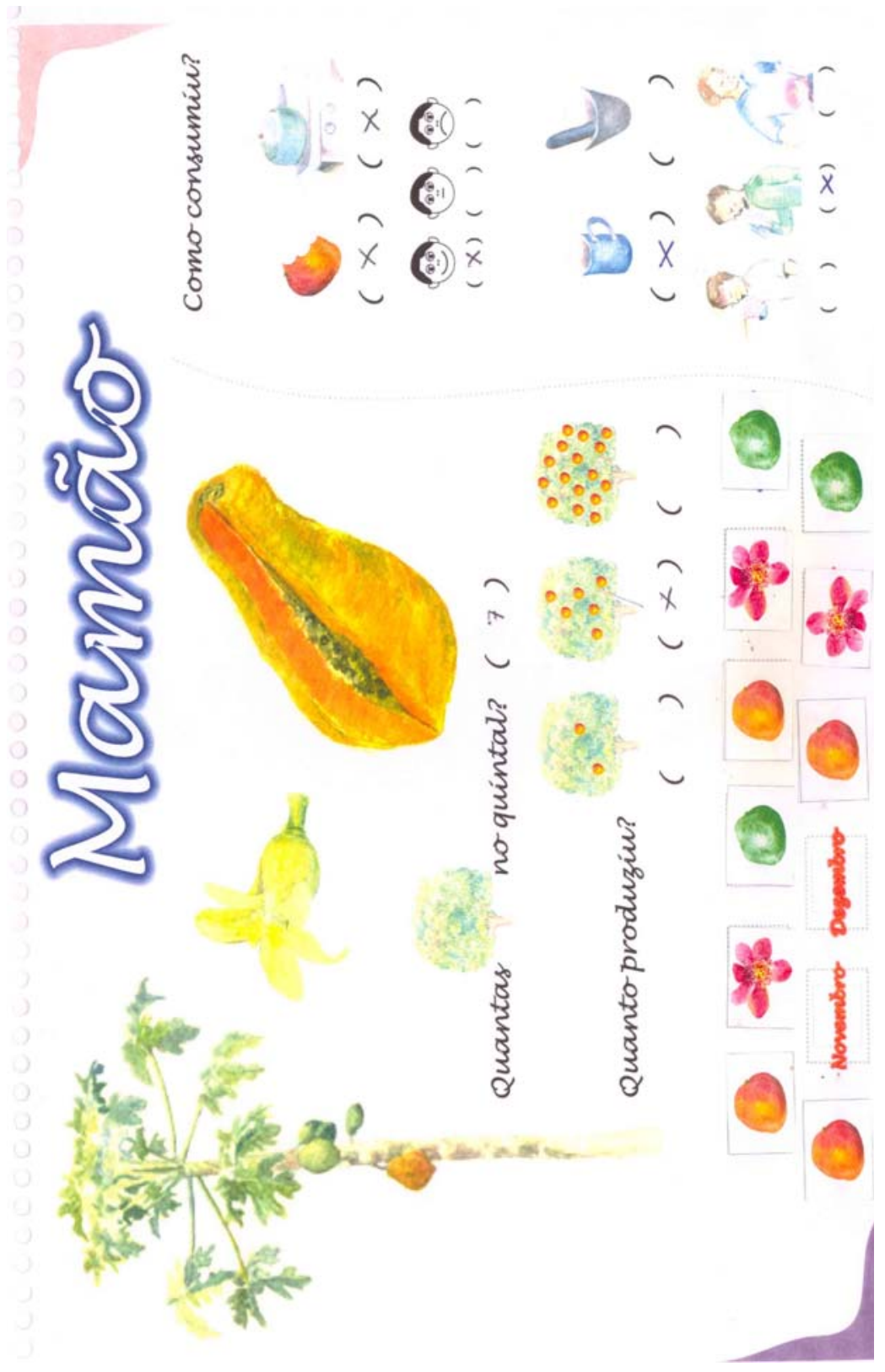


ANEXO C CALENDÁRIOS DAS FRUTEIRAS - EXEMPLO PREENCHIDO

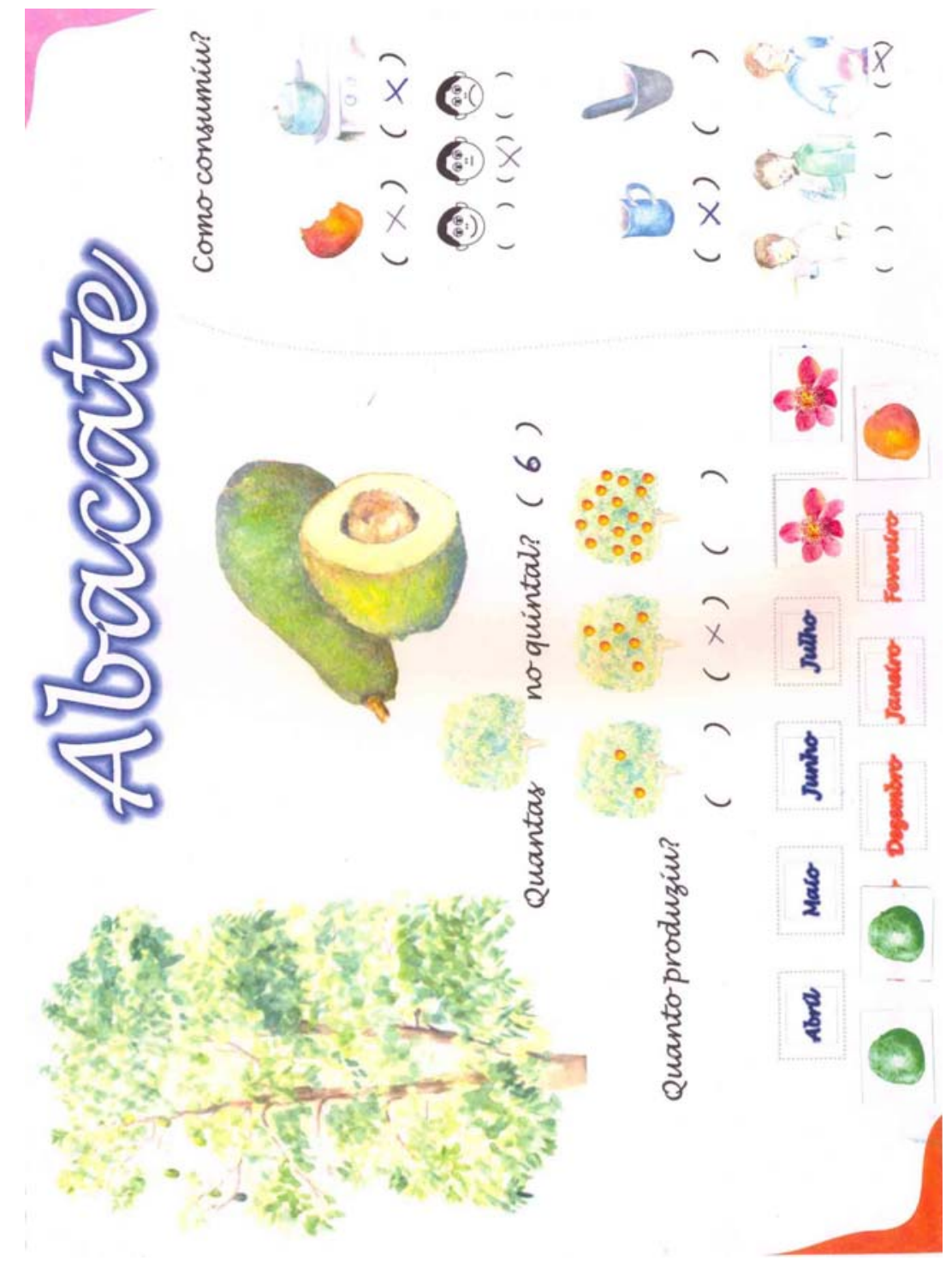


ANEXO C CALENDÁRIOS DAS FRUTEIRAS - EXEMPLO PREENCHIDO

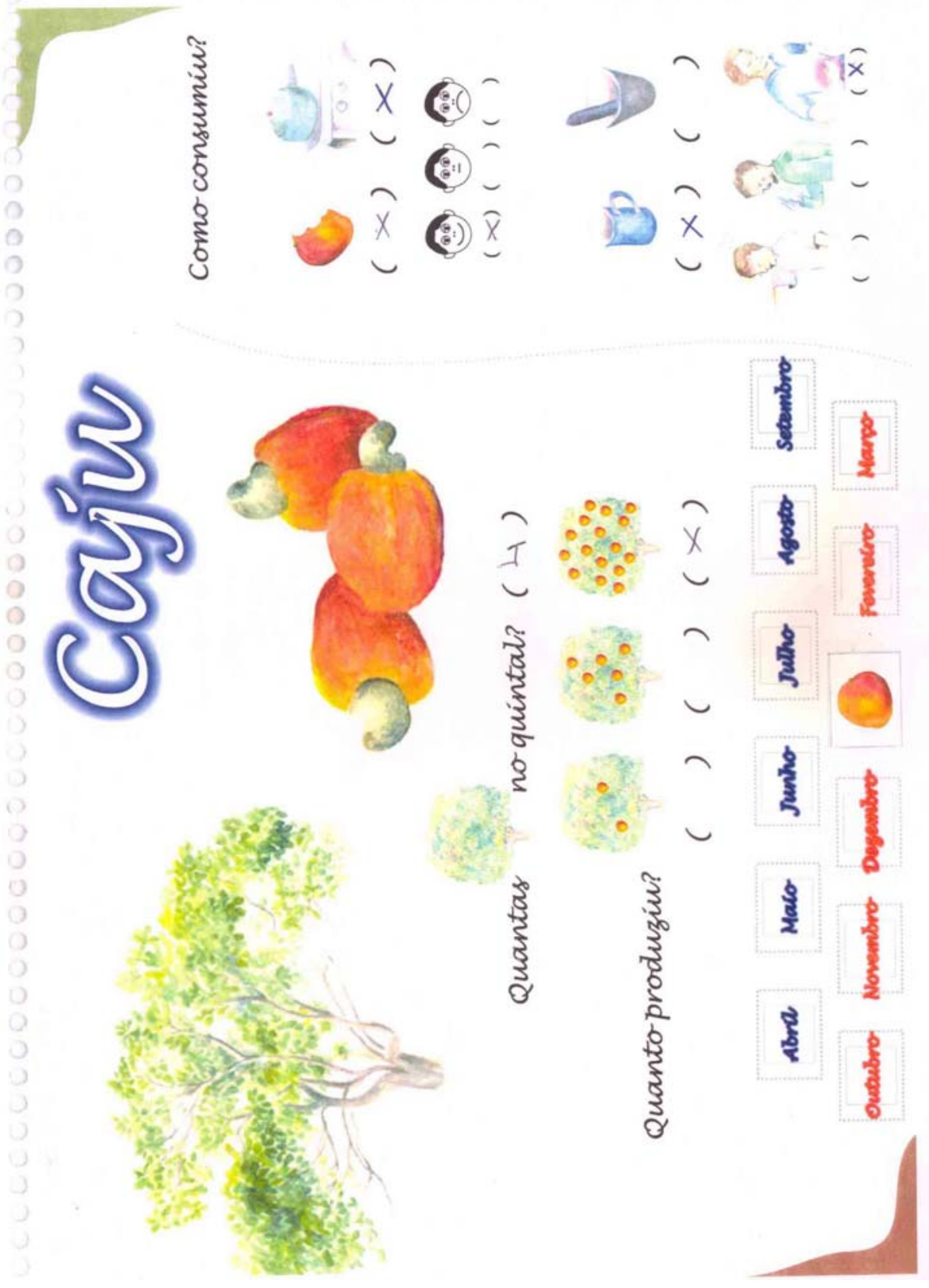


ANEXO C CALENDÁRIOS DAS FRUTEIRAS - EXEMPLO PREENCHIDO

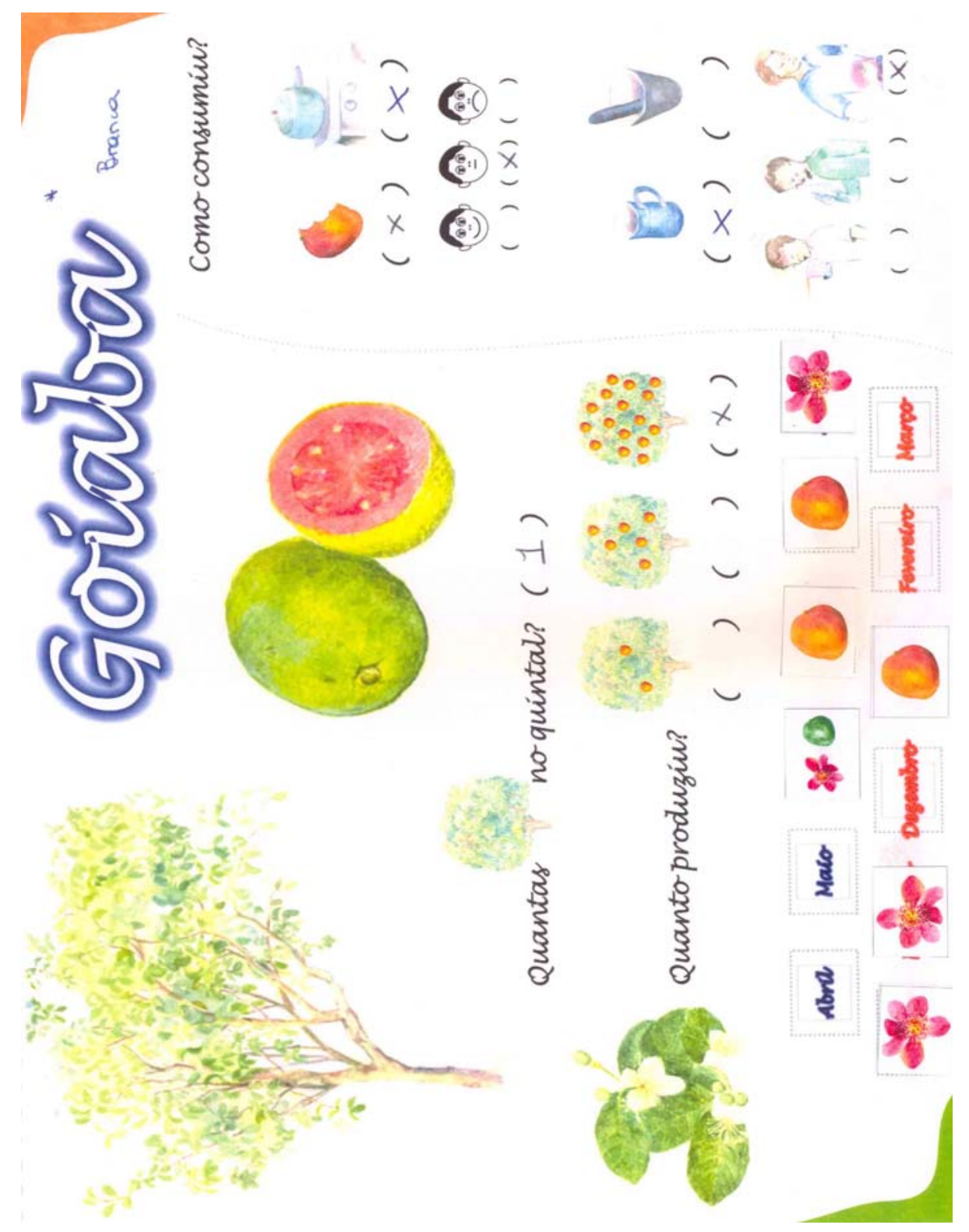


ANEXO C CALENDÁRIO FRUTEIRAS- EXEMPLO PREENCHIDO

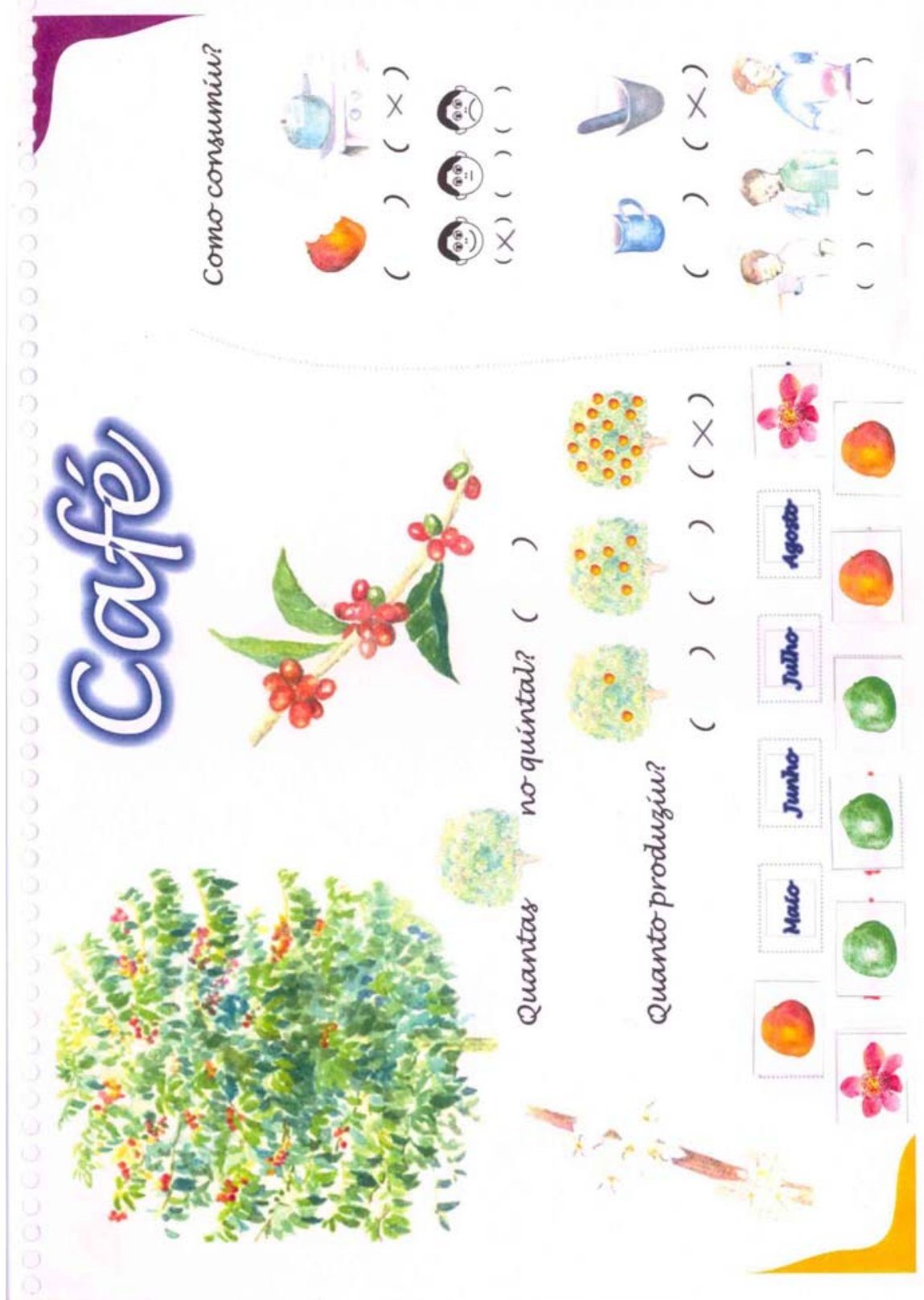


ANEXO D - QUADRO COM AS ATIVIDADES VIAGENS DE CAMPO

\begin{tabular}{|c|c|c|}
\hline Data & Dias de campo & Atividades desenvolvidas \\
\hline $\begin{array}{l}10 \text { Viagem 22/01- } \\
26 / 01 / 01\end{array}$ & 4 & $\begin{array}{l}\text { Apresentação do projeto à comunidade e à } \text { AMAM }^{*} \text {; seleção dos quintais e } \\
\text { visitas aos grupos domésticos; participação em reuniões da AMAM e da } \\
\text { Prefeitura de Paraty com a comunidade. }\end{array}$ \\
\hline $\begin{array}{l}2^{0} \text { Viagem } \\
14 / 03-22 / 03 / 01\end{array}$ & 8 & Início dos levantamentos sócio- ambientais; dieta familiar e coleta botânica. \\
\hline $\begin{array}{l}3^{0} \text { Viagem } \\
25 / 04-28 / 04 / 01 \\
\end{array}$ & 3 & $\begin{array}{l}\text { Visitas a } 2 \text { novos povoados e apresentação do projeto; continuidade dos } \\
\text { levantamentos. }\end{array}$ \\
\hline 29/04- 05/05/01 & 7 & $\begin{array}{l}\text { Disciplina pós-graduação Monitora do Grupo que estudou os quintais e a } \\
\text { relação destes com o turismo }\end{array}$ \\
\hline $\begin{array}{l}4^{0} \text { viagem } \\
\text { 02/08- } 14 / 08 \\
30 / 08 / 01 \text { reunião }\end{array}$ & 11 & $\begin{array}{l}\text { Levantamentos sócio- ambientais; dieta familiar e coleta botânica. } \\
\text { Participação em reuniões (Comitê da } R E J^{* *} \text {, Conselho da APA do Cairuçu) e } \\
\text { reunião com os representantes das comunidades da REJ; elaboração de } \\
\text { informativo sobre o SNUC. }\end{array}$ \\
\hline $\begin{array}{l}5^{0} \text { viagem } \\
5 / 06-17 / 06\end{array}$ & 11 & Levantamentos sócio- ambientais; dieta familiar e coleta botânica \\
\hline $\begin{array}{l}60 \text { viagem } \\
27 / 09-03 / 10\end{array}$ & 6 & $\begin{array}{l}\text { Levantamentos sócio- ambientais; dieta familiar e ênfase nas coletas } \\
\text { botânicas }\end{array}$ \\
\hline $\begin{array}{l}7^{0} \text { viagem } \\
03 / 12-11 / 12 \\
18 / 12 / 2001\end{array}$ & 8 & $\begin{array}{l}\text { Levantamento de dietas, coleta botânica de material reprodutivo, } \\
\text { observação da fenologia das principais fruteiras, apresentação do relatório } \\
\text { aos responsáveis pelos GDs, participação na reunião do Comitê Gestor da } \\
\text { APA do Cairuçu; participação em reuniões da AMAM }{ }^{30} \text {. } \\
\text { Participação em reunião da apresentação do pré- Plano de Gestão da APA } \\
\text { do Cairuçu, pela SOS Mata Atlântica. }\end{array}$ \\
\hline $\begin{array}{l}8^{0} \text { Viagem } 15 / 01- \\
04 / 02 / 02\end{array}$ & 21 & $\begin{array}{l}\text { Distribuição dos calendários das fruteiras dos quintais, medições da área de } \\
\text { quintal; perfis vertical e horizontal de } 12 \text { quintais; levantamento de dietas e } \\
\text { coleta botânica; levantamento de preços dos principais produtos obtidos nos } \\
\text { quintais em Paraty. }\end{array}$ \\
\hline $\begin{array}{lr}100 & \text { Viagem } \\
28 / 10 / 02-03 / 11 / 02\end{array}$ & 6 & $\begin{array}{l}\text { Recolhimento dos calendários, checagem de dados, e finalização das } \\
\text { atividades na comunidade - despedidas... (do lugar e das pessoas). }\end{array}$ \\
\hline Total & 93 & \\
\hline
\end{tabular}


ANEXO E - ARTIGO DE JORNAL

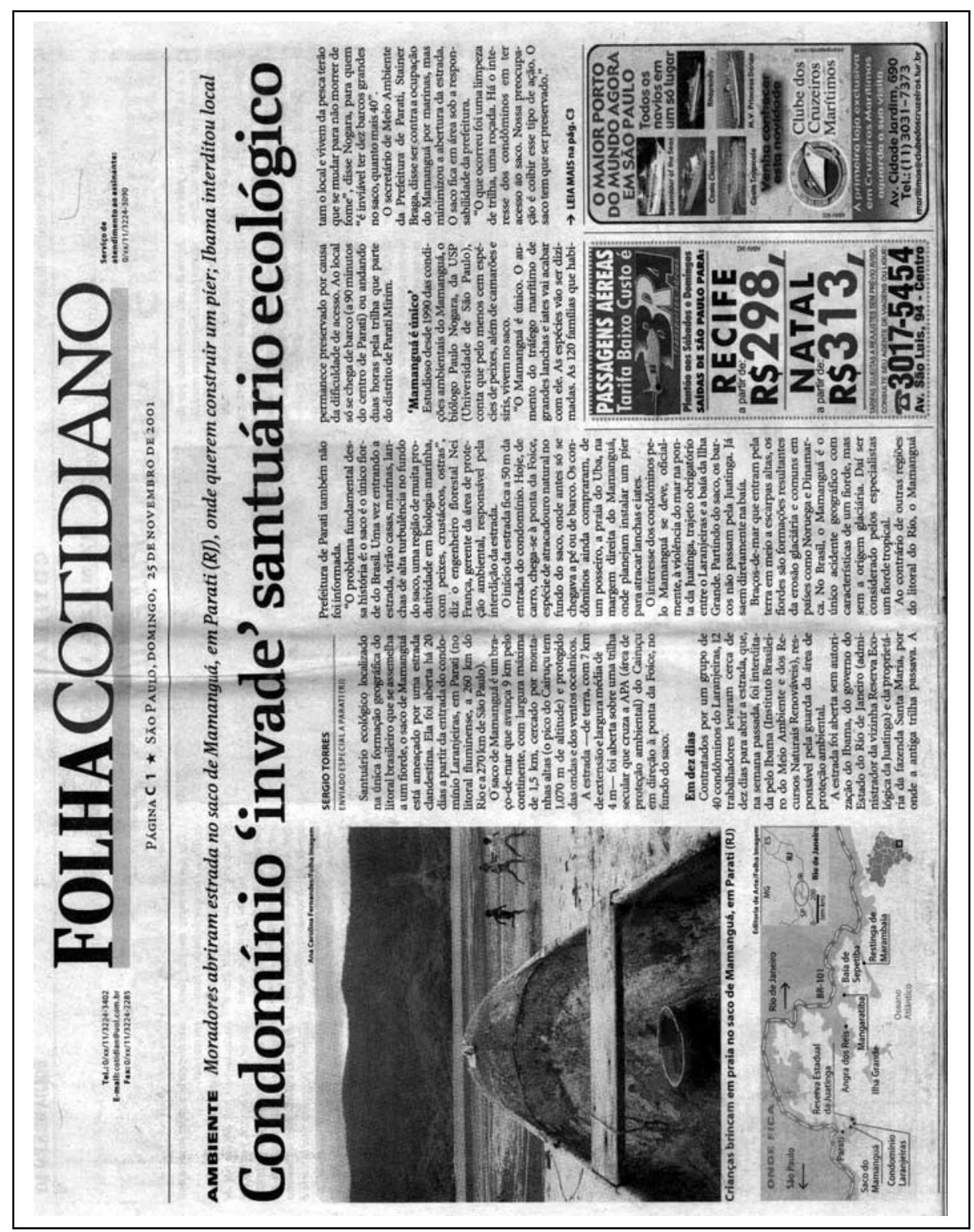




\title{
ANEXO F - INFORMATIVO PRODUZIDO PARA SER APRESENTADO EM UMA REUNIÃO COM AS LIDERANÇAS DAS COMUNIDADES DA RESERVA ECOLÓGICA DA JUATINGA
}

\author{
INFORMATIVO I
}

AGOSTO DE 2001

\section{Para saber mais....}

\section{PARA COMEÇAR...}

Este informativo tem o objetivo de organizar algumas perguntas e respostas a fim de esclarecer o processo em discussão da RECLASSIFICAÇÃO da Reserva Ecológica da JuatingaParaty- RJ. - REJ.

As primeiras perguntas de muitas outras que possam aparecer...

- O que é Reserva Ecológica da Juatinga- REJ?

A REJ foi criada em 1991 pela Lei Estadual no 1859 de 01/10/91.

A área abrange cerca de 2.000 ha.

Existem 12 comunidades caiçaras que vivem e utilizam os recursos naturais dentro da REJ, somando aproximadamente 400 famílias e cerca de 2000 pessoas.

Saco do Mamanguá; Praia Grande da Cajaíba; Martins de Sá; Saco das Anchovas; Itaoca; Calhaus; Pouso; Juatinga; Cairuçu das Pedras; Ponta Negra e Sono

- Qual o objetivo da REJ?

A REJ tem como objetivo:

"A preservação do ecossistema local que possui costões, o que restou (remanescentes) da Floresta Atlântica, restingas e manguezais. Além de incentivar a Cultura Caiçara, através de programas de Educação Ambiental, de forma que atividades desenvolvidas pelos caiçaras conservem a Natureza ou o Meio Ambiente".

- Quem administra a REJ?? 
A REJ é administrada pelo Instituto Estadual de Florestas que está ligado à Secretaria do Estado do Meio Ambiente e Desenvolvimento Sustentável. E é também o IEF responsável pelos programas de Educação Ambiental.

- O Que está em discussão ...

Está sendo discutido a RECLASSIFICAÇÃO da REJ.

- E por quê??

Para que a REJ seja integrada ao Sistema Nacional de Unidades de Conservação- UC Como está o processo de Discussão??

Diante da proposta de RECLASSIFICAÇÃO a sociedade se organizou está sendo representada pelos seguintes Integrantes:

Representantes das comunidades;

Instituto Estadual de Florestas - IEF;

Instituto de Terras do Rio de Janeiro- ITERJ;

Prefeitura de Paraty;

Proprietários de terras dentro da REJ;

Organizações Não- Governamentais- ONGs (representadas pela SOS Mata Atlântica, Verde Cidadania);

Universidade (representada pelo NUPAUB e pelos laboratórios- LASTROP E AGROLAB, USP).

As reuniões têm acontecido em Paraty desde de abril. Em agosto estão acontecendo no plenário da Câmara Municipal Foram realizadas 7 reuniões até o momento.

- Qual é o papel da Universidade??

Desenvolver trabalhos individuais e em conjunto dentro da Reserva da Juatinga $E$ na área de Proteção Ambiental APA do Cairuçu. Estes trabalhos são realizados em forma de 
pesquisa, formação (educação) e extensão e contribuem nas decisões e políticas públicas em processos como este de RECLASSIFICAÇÃO de uma Unidade de Conservação, a REJ.

O NUPAUB-USP, o LASTROP/ESALQ-USP e o AGROLAB-USP se posicionam favoravelmente à reclassificação da REJ como Reserva de Desenvolvimento Sustentável. Este tipo de Unidade de Conservação considera a população local e busca a sustentabilidade das atividades ligadas à Natureza, assim como garante sua permanência em terras de DOMíNIO PÚBLICO. Considera também a GESTÃO PARTICIPATIVA das comunidades envolvidas. Ë uma forma inventada no Brasil para promover a conservação da natureza junto com a melhoria da qualidade de vida das populações presentes em Unidades de Conservação.

- Qual é o papel da população local...

Se posicionar diante das opções de classificação da REJ e por isso é importante participar das reuniões através de seus legítimos representantes e transmitir as informações ao restante da comunidade e incentivar a participação de um número maior de pessoas nas discussões e encaminhamentos.

- E por quê?

Por que é o seu lugar, o seu modo de vida, a sua permanência que estão sendo discutidos! A sua participação, sua opinião, seu sentimento para com o lugar e para com seus filhos, netos será determinante nas decisões do presente que irão refletir no futuro.

\section{O QUE SIGNIFICAM AS PALAVRAS?}

\section{Unidades de Conservação -}

Áreas protegidas criadas pelo governo para conservar elou preservar os recursos ambientais.

\section{Sistema Nacional de Unidades de Conservação- SNUC}

Lei de 2000 que diz como as Unidades de Conservação são criadas, implantadas e administradas.

Conservação - Manejo + Preservação + Utilização Sustentável (usar os ecossistemas sem destruir, mantendo a capacidade do sistema e a qualidade de vida para filhos e netos.

\section{Preservação}


Políticas e Métodos para manter os ecossistemas equilibrados sem a utilização para produção pelas populações humanas.

Manejo = Cuidar ... para que a floresta, o mar ou as roças produzam sempre sem acabar.

Desenvolvimento Sustentável- Forma de utilização dos recursos que considera e respeita a parte Ambiental, Social, e Econômica da cadeia de produção desde a matéria prima até o consumidor.

E o que significam as Siglas?

\begin{tabular}{|l|l|l|}
\hline Siglas- Instituições & O que significa & Contato \\
\hline \multirow{2}{*}{ NUPAUB-USP } & $\begin{array}{l}\text { Núcleo de Apoio à Pesquisa sobre Populações } \\
\text { Humanas e Áreas Úmidas Brasileiras } \\
\text { Coord. Prof. Dr. Antônio Carlos S. Diegues. }\end{array}$ & \\
\hline LASTROP-USP & $\begin{array}{l}\text { Laboratório de Silvicultura Tropical } \\
\text { Coord. Prof. Dr. Virgílio M. Viana }\end{array}$ & $\begin{array}{l}\text { Renata Fraire/Valquíria } \\
\text { Garrote }\end{array}$ \\
\hline AGROLAB-USP & Laboratório de Geografia Agrária. & Lúcia Cavalieri \\
\hline IEF & Instituto Estadual de Florestas & $\begin{array}{l}\text { Paulo Schiavo Dália e João } \\
\text { Fernandes }\end{array}$ \\
\hline IBAMA & $\begin{array}{l}\text { Instituto Brasileiro do Meio Ambiente e dos } \\
\text { Recursos Renováveis }\end{array}$ & Ney França Pinto \\
\hline ITERJ & Instituto Estadual de Terras do Rio de Janeiro & \\
\hline
\end{tabular}

Esse informativo foi apresentado em uma das reuniões que participei (31/08/2001) com 8 representantes das comunidades da REJ. Estes representantes convidaram pessoas das Universidades que desenvolviam trabalhos na região a participarem de um encontro só com representantes das comunidades para esclarecimento de dúvidas e para definirem estratégias de organização frente a este problema. Este texto foi elaborado por mim: Valquíria Garrote (LASTROP/USP), Lúcia Cavallieri (AGROLAB/USP) e Paulo Nogara (NUPAUB/USP). 
ANEXO G - Listagem Botânica Das Plantas Coletadas Nos Dezenove Quintais Do Saco Do Mamanguá Paraty- RJ.

\begin{tabular}{|l|l|l|l|l|}
\hline Nome Popular & Nome científico & Família & Uso & Hábito \\
\hline Abacate amarelo & Persea americana, L. & Lauraceae & $\begin{array}{l}\text { Alimentação } \\
\text { Medicinal }\end{array}$ & Arbórea Cultivada \\
\hline Abacate branco & Persea americana, L. & Lauraceae & $\begin{array}{l}\text { Alimentação } \\
\text { Medicinal }\end{array}$ & Arbórea Cultivada \\
\hline Abacate coco & Persea americana, L. & Lauraceae & $\begin{array}{l}\text { Alimentação } \\
\text { Medicinal }\end{array}$ & Arbórea Cultivada \\
\hline Abacate roxo & Persea americana, L. & Alimentação & Medicinal & Arbórea Cultivada \\
\hline Abacaxi & Ananas comusos, L. Merril & Alimentação & Herbácea \\
\hline Abiu & Pouteria cainito, (Ruiz \& Pav.) & Bromeliaceae & Alimentação & Arbórea Cultivada \\
\hline Abiu roxo & Pouteria cainito, (Ruiz \& Pav.) & Sapotaceae & Alimentação & Arbórea Cultivada \\
\hline Abóbora & Cucurbita sp & Cucurbitaceae & Alimentação & Herbácea \\
\hline Abóbora menina & Cucurbita sp & Cucurbitaceae & Alimentação & Herbácea \\
\hline Abricó & Mammea americana, L. & Clusiaceae & Alimentação & Arbórea Cultivada \\
\hline Abuta & Chondodendron platyphilum (A St. Hill) & Menispermaceae & Medicinal & Herbácea \\
\hline Acerola & Miers Ann m & Malpighiaceae & Alimentação & Arbustiva Cultivada \\
\hline aAçucenaena & Malpighia glabra, L. & Ornamental & Herbácea \\
\hline Açucena (gigante) & Hippeastrum puniceum, (Lam.) Voos & Amaryllidaceae & Ornamental & Herbácea \\
\hline Aipim & Crinum x powelii, Hort. Ex Baker & Amaryllidaceae & Alimentação & Arbustiva Cultivada \\
\hline Alecrim & Manihot sp & Euphorbiaceae & Condimento & Herbácea \\
\hline Alecrim de cheiro & Rosmarinus officinalis, L. & Lamiaceae & Medicinal/condimen. & Herbácea \\
\hline
\end{tabular}


ANEXO G - Listagem Botânica Das Plantas Coletadas Nos Dezenove Quintais Do Saco Do Mamanguá Paraty- RJ.

\begin{tabular}{|c|c|c|c|c|}
\hline Nome Popular & Nome científico & Família & Uso & Hábito \\
\hline Aleluia & Senna bicapsulares, (L.) Roxb. & Caesalpiniaceae & Outros & Arbórea Nativa \\
\hline Alface & Lactuva sativa, & Asteracea & Alimentação & Herbácea \\
\hline Alfavaca & Ocimum basilicu,L. & Lamiaceae & Condimento & Herbácea \\
\hline Algodão & Gossypium barbadense, L. & Malvaceae & Medicinal e outros & Arbustiva Cultivada \\
\hline Ameixeira & Prunus domestica, L. & Rosaceae & Alimentação & Arbórea Cultivada \\
\hline Amendoim & Arachis hypogae, Lin. & Fabaceae & Alimentação & Herbácea \\
\hline Amora & Morus nigra, L. & Moraceae & $\begin{array}{l}\text { Alimentação } \\
\text { Medicinal }\end{array}$ & Arbórea Cultivada \\
\hline Anador & Altenanthera cf brasiliana, (L.), O. Kuntze & $\mathrm{NI}$ & Medicinal & Herbácea \\
\hline Anestesia & Clorodendro sp & Acanthaceae & Medicinal & Herbácea \\
\hline Anis & Pimpinella anisum, L. & Umbelifera & Medicinal & Herbácea \\
\hline Antúrio & Anthurium $x$ froebelli, Hort. & Araceae & Ornamental & Herbácea \\
\hline Araça & Psidium cattleyanum, Sabino & Myrtaceae & Alimentação & Arbórea Nativa \\
\hline Aroeira Pimenteira & Schinus terebintifhifolius, Roddi & Anacardiaceae & Outros & Arbórea Nativa \\
\hline Arruda & Ruta graveolenses, L. & Rutaceae & Medicinal & Herbácea \\
\hline Ata & Annona sp & Annonaceae & Alimentação & Arbórea Cultivada \\
\hline Avenca & Adianthum sp & Pteridaceae & Ornamental & Herbácea \\
\hline Avenca verde & Adianthum sp & Pteridaceae & Ornamental & Herbácea \\
\hline Avenca vermelha & Adianthum sp & Pteridaceae & Ornamental & Herbácea \\
\hline Babosa & Aloe vera, $\mathrm{L}$. & Aloeaceae & Medicinal & Herbácea \\
\hline Baleeira & Julocroton cf sp & Euphorbiaceae & Outros & Arbórea Nativa \\
\hline Bambú & Pogonatherum paniceum, Hack & Gramineae & Outros & Arbórea Cultivada \\
\hline Bambuzinho & Bambusa gracilis, Hort. Ex C. Rivière & Gramineae & Ornamental & Arbustiva Cultivada \\
\hline Banana Bacubita & Musa sapientum, & Musaceae & Alimentação & Arbustiva Cultivada \\
\hline
\end{tabular}


ANEXO G - Listagem Botânica Das Plantas Coletadas Nos Dezenove Quintais Do Saco Do Mamanguá Paraty- RJ.

\begin{tabular}{|c|c|c|c|c|}
\hline Nome Popular & Nome científico & Família & Uso & Hábito \\
\hline Banana Cinzenta & Musa sp & Musaceae & $\begin{array}{l}\text { Alimentação } \\
\text { Medicinal }\end{array}$ & Arbustiva Cultivada \\
\hline Banana Maça & Musa sp & Musaceae & Alimentação & Arbustiva Cultivada \\
\hline Banana Nanica & Musa paradisiaca,L & Musaceae & Alimentação & Arbustiva Cultivada \\
\hline Banana Prata & Musa sapientum,L. Kuntze & Musaceae & $\begin{array}{l}\text { Alimentação } \\
\text { Medicinal }\end{array}$ & Arbustiva Cultivada \\
\hline Banana Prata veiaca & Musa sp & Musaceae & Alimentação & Arbustiva Cultivada \\
\hline Banana São Tomé & Musa sapientum,L. Kuntze & Musaceae & Alimentação & Arbustiva Cultivada \\
\hline Banana Terra & Musa paradisiaca, L. & Musaceae & Alimentação & Arbustiva Cultivada \\
\hline Batata doce & Ipomea sp & Convolvulaceae & Alimentação & Herbácea \\
\hline Begônia 1 & Begonia sp & Begoniaceae & Ornamental & Herbácea \\
\hline Begônia 2 & Begonia aconitifolia, A DC. & Begoniaceae & Ornamental & Herbácea \\
\hline Begônia 3 & Begonia boveri,Ziesenh. & Begoniaceae & Ornamental & Herbácea \\
\hline Begônia 4 & Begonia $x$ sementaceae,Hort & Begoniaceae & Ornamental & Herbácea \\
\hline Begônia 5 & Begonia cf coccinea, Hook & Begoniaceae & Ornamental & Herbácea \\
\hline Begônia 6 & Begonia cucullata, Willd. & Begoniaceae & Ornamental & Herbácea \\
\hline Begônia 7 & Begonia manicata, Cels. Ex Vis & Begoniaceae & Ornamental & Herbácea \\
\hline Begônia 8 & Begonia masoniana, Irmsch. & Begoniaceae & Ornamental & Herbácea \\
\hline Begônia 9 & Bergenia crassifolia, Fritsch. & Saxifragaceae & Ornamental & Herbácea \\
\hline \begin{tabular}{|l|l|} 
Beijo (Maria sem \\
vergonha)
\end{tabular} & Impatiens walleriana, Hook. F & Balsaminaceae & Ornamental & Herbácea \\
\hline Bengala amarela & Bidens fenelifolia, (Jacq) Sweet. & Asteracea & Ornamental & Herbácea \\
\hline Bengala vermelha & Bidens fenelifolia, (Jacq) Sweet. & Asteracea & Ornamental & Herbácea \\
\hline Boa Noite & Catharanthus roseus, G. Don & Apocynaceae & Ornamental & Herbácea \\
\hline
\end{tabular}


ANEXO G - Listagem Botânica Das Plantas Coletadas Nos Dezenove Quintais Do Saco Do Mamanguá Paraty- RJ.

\begin{tabular}{|c|c|c|c|c|}
\hline Nome Popular & Nome científico & Família & Uso & Hábito \\
\hline Boca de lobo & Sinningia speciosa, Baill. & Gesneriaceae & Ornamental & Herbácea \\
\hline Boca de moça & Salvia splendens, Ker Grawe & Lamiaceae & Ornamental & Herbácea \\
\hline Boldo arbusto & Plectrantus cf barbatus, Andr & Lamiaceae & Medicinal & Arbustiva Cultivada \\
\hline Boldo da china & Plectranthus, sp & Lamiaceae & Medicinal & Herbácea \\
\hline Boldo rasteiro & Plectrantus, sp & Lamiaceae & Medicinal & Herbácea \\
\hline Brinco de rainha & Hibiscus schizopetalus, Hook. f. & Malvaceae & Ornamental & Arbustiva Cultivada \\
\hline Cabaça & Guarea macrophyla, Vahl. & Bignoniacea & Outros & Arbórea Cultivada \\
\hline Cabacinha & Crescentia cujete, L. & Bignoniacea & Outros & Arbórea Cultivada \\
\hline Cabeludinha & Plinia glomerata, (O. Berg) Amshoff Myrt. & Myrtaceae & Alimentação & Herbácea \\
\hline Cacau & Theobroma cacao,L. & Sterculiaceae & Alimentação & Arbórea Cultivada \\
\hline Café & Coffea arabica,L. & Rubiaceae & Alimentação & Arbustiva Cultivada \\
\hline Caixeta & $\begin{array}{l}\text { Tabebuia cassinoides,(Lam.) A. P. de } \\
\text { Condolle }\end{array}$ & Bignoniacea & Outros & Arbórea Nativa \\
\hline Cajamanga & $\begin{array}{l}\text { Spondias cytheia, Sonn.(Seg. Engl. \& } \\
\text { Prantl.) }\end{array}$ & Anacardiaceae & Alimentação & Arbórea Cultivada \\
\hline Caju & Anacardium occidentalis, L. & Anacardiaceae & Alimentação & Arbórea Cultivada \\
\hline Cajú amarelo & Anacardium occidentalis, L. & Anacardiaceae & Alimentação & Arbórea Cultivada \\
\hline Cajú vermelho & Anacardium occidentalis, L. & Anacardiaceae & Alimentação & Arbórea Cultivada \\
\hline Cajuja & Aegiphila sellowiana, Cham & Verbenaceae & Outros & Arbórea Nativa \\
\hline Camarão & Pachystachys lutea, Nees & Acanthaceae & Ornamental & Herbácea \\
\hline Cambara de cruz & $\mathrm{NI}$ & $\mathrm{NI}$ & Medicinal & Herbácea \\
\hline Cambucá & Gomidesia flagellaris, D. Legrand & Myrtaceae & Alimentação & Arbórea Nativa \\
\hline Cambucá mirim & $\mathrm{NI}$ & Myrtaceae & Alimentação & Arbórea Nativa \\
\hline Camomila & Achilea millefolium, L. & Asteracea & Medicinal & Herbácea \\
\hline
\end{tabular}


ANEXO G - Listagem Botânica Das Plantas Coletadas Nos Dezenove Quintais Do Saco Do Mamanguá Paraty- RJ.

\begin{tabular}{|c|c|c|c|c|}
\hline Nome Popular & Nome científico & Família & Uso & Hábito \\
\hline Cana & Saccharium officinarum, $\mathrm{L}$ & Gramineae & Alimentação & Herbácea \\
\hline Cana do Brejo & Costus, sp & Zingiberaceae & Ornamental & Herbácea \\
\hline Canafístula & Pelthophorium dubium, (Spreng.) Taub. & Caesalpiniaceae & Outros & Arbórea Nativa \\
\hline Candiúba & Trema micrantha, (L.) Blume & Ulmaceae & Outros & Arbórea Nativa \\
\hline Canela & NI & $\mathrm{NI}$ & Outros & Arbórea Nativa \\
\hline Capim limao (cidreira) & Cymbopogon citratus, (D.C.) Stapf & Gramineae & Medicinal & Herbácea \\
\hline Capororoca & Rapanea ferruginea, (Ruiz \& Pav.) Mez & Myrsinaceae & Outros & Arbórea Nativa \\
\hline Capotinho & $\mathrm{NI}$ & Menispermaceae & Medicinal & Cipo \\
\hline Caqui & Diospyros kaki, L. & Ebenaceae & Alimentação & Arbórea Cultivada \\
\hline Cará & Dioscorea alata, L. & Dioscoreaceae & Alimentação & Herbácea \\
\hline Caraguatá & Ananas sp & Bromeliaceae & Ornamental & Herbácea \\
\hline Caramanchao & Bongainville spectabilis, Willd & Nyctaginaceae & Ornamental & Arbustiva Cultivada \\
\hline Carambola & Averhoa carambola, L. & Oxalidaceae & Alimentação & Arbórea Cultivada \\
\hline Carne seca & Guapira, (Vell.) Brenan & Nyctaginaceae & Outros & Arbórea Nativa \\
\hline Carobinha & $\begin{array}{l}\text { Jacaranda bracteata, Bureau \& K. } \\
\text { Schumann }\end{array}$ & Bignoniacea & Outros & Arbórea Nativa \\
\hline Carqueja & Baccharis genistelloides (Lam.) Pers. & Asteracea & Medicinal & Herbácea \\
\hline Casca preta & Rollinia cf sericea, (R.E. Fr.) R.E. Fr. & Annonaceae & Outros & Arbórea Nativa \\
\hline Castanheira & Bombacopsis glabra, (Pasq.) A. Rob. & Bombacaceae & Outros & Arbórea Cultivada \\
\hline Castiçal & Brugmansia suaveolens, Bercht \& Presl & Solanaceae & Ornamental & Arbustiva Nativa \\
\hline Catinga de mulata & Dyctyoma vandellianum, A. Juss. & Rutaceae & Outros & Arbórea Nativa \\
\hline Cebolinha & Allium fistulosum, L. & Liliaceae & Condimento & Herbácea \\
\hline Cedrinho & Melia azedarach L. & Meliaceae & Outros & Arbórea Nativa \\
\hline
\end{tabular}


ANEXO G - Listagem Botânica Das Plantas Coletadas Nos Dezenove Quintais Do Saco Do Mamanguá Paraty- RJ.

\begin{tabular}{|c|c|c|c|c|}
\hline Nome Popular & Nome científico & Família & Uso & Hábito \\
\hline Cedro & Cedrela fissilli, Vell. & Meliaceae & Outros & Arbórea Nativa \\
\hline Cenoura & Daucus carota, L. & Umbelifera & Alimentação & Herbácea \\
\hline Cereja & Bunchosia armeniaca, (Cav.) DC. & Malpighiaceae & Alimentação & Arbórea Nativa \\
\hline Chagas & Caesalpinia pulcherrima, SW & Caesalpiniaceae & Ornamental & Arbórea Nativa \\
\hline Chapéu de couro & $\begin{array}{l}\text { Echinodorus grandiflorus (Cham. \& } \\
\text { Schltd.) Mich. }\end{array}$ & Alimatideae & Medicinal & Herbácea \\
\hline Chapéu de sol & $\mathrm{NI}$ & $\mathrm{NI}$ & Outros & Arbórea Cultivada \\
\hline Cheflera & Scheflera arboricola, (Hayata) Merr. & Araliciceae & Ornamental & Herbácea \\
\hline Chicória & Chicorium endiva, L. & Chicoreaceae & Alimentação & Herbácea \\
\hline Chifre de veado & Platycerium bifucatum, (Cav.) Chr. & Polypodiaceae & Ornamental & Herbácea \\
\hline Chorão de jardim & Tibouchina sp 2 & Melastomataceae & Ornamental & Arbustiva Nativa \\
\hline Chorão do mato & Tibouchina sp 1 & Melastomataceae & Outros & Arbórea Nativa \\
\hline Chuchu & Sechium edule,Sw. & Cucurbitaceae & Alimentação & Cipo \\
\hline Chuva de ouro & Oncidium varicosum, Lindl. & Orchidaceae & Ornamental & Epifita \\
\hline Cica & Cycas revoluta, Thumb. & Cycadaceae & Ornamental & Herbácea \\
\hline Cinco Chagas (Tarumã & & Caesalpiniaceae & Ornamental & Arbórea Nativa \\
\hline Ciosa ou Lírio do brejo & Hedychium coronarium, Koehne & Zingiberaceae & \begin{tabular}{|l|} 
Medicinal \\
ornamental
\end{tabular} & Herbácea \\
\hline Cipó & Heteropterys sp & Malpighiaceae & Ornamental & Cipo \\
\hline Citronela & $\mathrm{NI}$ & $\mathrm{NI}$ & Medicinal & Herbácea \\
\hline Cobi & Anadenanthera colubrina, (Vill.) Brenan & Mimosaceae & Outros & Arbórea Nativa \\
\hline Cobitinga & Croton floribundus, (L.) Spreng. & Euphorbiaceae & Outros & Arbórea Nativa \\
\hline Coco Anã & Cocos nucifera & Arecaceae & Alimentação & Arbórea Cultivada \\
\hline Coco Bahia & Cocos nucifera & Arecaceae & Alimentação & Arbórea Cultivada \\
\hline
\end{tabular}


ANEXO G - Listagem Botânica Das Plantas Coletadas Nos Dezenove Quintais Do Saco Do Mamanguá Paraty- RJ.

\begin{tabular}{|c|c|c|c|c|}
\hline Nome Popular & Nome científico & Família & Uso & Hábito \\
\hline Coco Indaiá & Attalea dubia, (Mart.) & Arecaceae & Ornamental e outros & Arbórea Nativa \\
\hline Coco Pati & $\mathrm{NI}$ & Arecaceae & Outros & Arbórea Nativa \\
\hline Coco Pindoba & Attalea humilis, Mart. ex Spreng. & Arecaceae & Alimentação e outros & Arbórea Nativa \\
\hline Coentrão & Eryginum horridum & Apiaceae & Condimento & Herbácea \\
\hline Coentro & Eryginum horridum & Apiaceae & Condimento & Herbácea \\
\hline Condessa & Rollinia mucosa (Jacq.) Baill. & Annonaceae & Alimentação & Arbórea Cultivada \\
\hline Confrei & NI & $\mathrm{NI}$ & Medicinal & Herbácea \\
\hline Copo de leite & Zantedeschi aethiopica & Araceae & Ornamental & Herbácea \\
\hline Coquinho & $\mathrm{NI}$ & Arecaceae & Ornamental & Arbórea Nativa \\
\hline Coração de mãe & Peperomia cf sandersii, C. DC. & Piperaceae & Ornamental & Herbácea \\
\hline Cordão de frade & $\mathrm{NI}$ & $\mathrm{NI}$ & Medicinal & Herbácea \\
\hline Coroa de cristo & Euphorbia milli, Des Moul. & Euphorbiaceae & Ornamental & Herbácea \\
\hline Costela de adão & Monstera deliciosa, Liebm. & Araceae & Ornamental & Herbácea \\
\hline Couve & Brassica oleraceae, L. & Cruciferae & Alimentação & Herbácea \\
\hline Cravo & Tagetes sp & Asteracea & Ornamental & Herbácea \\
\hline Cubatã & $N$ & $\mathrm{NI}$ & Outros & Arbórea Cultivada \\
\hline Dinheiro em penca & Pilea nummularifolia Wedd. & Urticaceae & Ornamental & Herbácea \\
\hline Doril & Pfaffia sp & Amaranthaceae & Medicinal & Herbácea \\
\hline Dracena & Dracena deremensis, Engl. & Liliaceae & Ornamental & Herbácea \\
\hline Dracena & Dracena fragans, Ker Gawl. & Liliaceae & Ornamental & Herbácea \\
\hline Embauba branca & Cecropia sp & Cecropiaceae & Medicinal & Arbórea Nativa \\
\hline Embauba vermelha & Cecropia sp & Cecropiaceae & Medicinal e outros & Arbórea Nativa \\
\hline Erva cidreira & Lippia alba, (Mill.) N. E. Br. & Verbenaceae & Medicinal & Herbácea \\
\hline
\end{tabular}


ANEXO G - Listagem Botânica Das Plantas Coletadas Nos Dezenove Quintais Do Saco Do Mamanguá Paraty- RJ.

\begin{tabular}{|c|c|c|c|c|}
\hline Nome Popular & Nome científico & Família & Uso & Hábito \\
\hline Erva de Santa Maria & Chenopodium ambrosoides & Chenopodiaceae & Medicinal & Herbácea \\
\hline Espada de santa rita & $\begin{array}{l}\text { Sansevieria trifasciata, Hort. Ex Paine } \\
\text { "Hahnii" }\end{array}$ & Liliaceae & Ornamental & Herbácea \\
\hline Espada de são jorge & $\begin{array}{l}\text { Sansevieria trifasciata, Hort. Ex Paine } \\
\text { "Laurentii" }\end{array}$ & Liliaceae & Ornamental & Herbácea \\
\hline Espadinha & $\begin{array}{l}\text { Sansevieria trifasciata, Hort. Ex Paine } \\
\text { "Hahnii }\end{array}$ & Liliaceae & Ornamental & Herbácea \\
\hline Espinheiro & $\mathrm{NI}$ & Mimosaceae & Outros & Arbórea Nativa \\
\hline Espirradeira & Nerium oleander, Linn & Apocynaceae & Ornamental & Arbórea Nativa \\
\hline Estomalina & Vernonia condesata, L. & Asteracea & Medicinal & Arbustiva Cultivada \\
\hline Executivo (boca preta) & Turnera ulmiflora, Linn & Turneraceae & Ornamental & Herbácea \\
\hline Fedegoso & Senna sp & Caesalpiniaceae & Ornamental e outros & Arbórea Nativa \\
\hline Fedegoso 1 & $\begin{array}{l}\text { Senna macrantha, (Colladon) H. S.Irwin } \\
\text { \& Barneb }\end{array}$ & Caesalpiniaceae & Ornamental e outros & Arbórea Nativa \\
\hline Fedegoso 2 & Senna alata, (L.) Roxb. & Caesalpiniaceae & Ornamental e outros & Arbórea Nativa \\
\hline Feijão corda & Vigna sinensis, Endl. & Fabaceae & Alimentação & Herbácea \\
\hline Feijão fava & Vigna sp & Fabaceae & Alimentação & Herbácea \\
\hline Figueira & $\begin{array}{l}\text { Ficus cf guaranitica, Chodat ex Chodat \& } \\
\text { Vicher }\end{array}$ & Moraceae & Outros & Arbórea Nativa \\
\hline Figueira & Ficus sp & Moraceae & Outros & Arbórea Nativa \\
\hline Figueira bca & Ficus sp & Moraceae & Outros & Arbórea Nativa \\
\hline Figueira vermelha & Ficus sp & Moraceae & Outros & Arbórea Nativa \\
\hline Figueirinha & Ficus benjamina & Moraceae & Ornamental & Arbustiva Cultivada \\
\hline Filodendro & Philodendro imbe, Schott & Araceae & Ornamental & Herbácea \\
\hline
\end{tabular}


ANEXO G - Listagem Botânica Das Plantas Coletadas Nos Dezenove Quintais Do Saco Do Mamanguá Paraty- RJ.

\begin{tabular}{|c|c|c|c|c|}
\hline Nome Popular & Nome científico & Família & Uso & Hábito \\
\hline Filodendro & Philodendron sp & Araceae & Ornamental & Herbácea \\
\hline Flecha de ubá & Gynerium sagittatum, P. Beauv & Gramineae & Ornamental & Arbórea Nativa \\
\hline Flor de cera & Hoya carnosa, R. Br. & Asclepiadaceae & Ornamental & Herbácea \\
\hline Flor de maio & Schlumbergera truncata, (Haw) & Cactaceae & Ornamental & Herbácea \\
\hline Flor roxa & Leea rubra, Blume & Vitaceae & Ornamental & Herbácea \\
\hline Folhagem 1 & Codiaeum variegatum, Blume & Euphorbiaceae & Ornamental & Arbustiva Cultivada \\
\hline Folhagem 2 & Graptophilum pictum, Griff & Acanthaceae & Ornamental & Herbácea \\
\hline Folhagem 3 & Syngonium podophyllum, Schott & Araceae & Ornamental & Herbácea \\
\hline Folhagem 4 & Euphrobia cotinifolia, Linn & Euphorbiaceae & Ornamental & Arbustiva Cultivada \\
\hline Folhagem 5 & Acalypha wilkesiana, Müll. Arg. & Euphorbiaceae & Ornamental & Herbácea \\
\hline Folhagem 5 & Codiaeum variegatum, Blume & Euphorbiaceae & Ornamental & Herbácea \\
\hline Folhagem 6 (dracena) & Cordyline terminalis, (Kunth) & Liliaceae & Ornamental & Herbácea \\
\hline Folhagem 7 & Calathea ornata, Körn & Marantaceae & Ornamental & Herbácea \\
\hline Fruta de Morcego 1 & Eugenia mosemii, O. Berg & Myrtaceae & Outros & Arbórea Nativa \\
\hline Fruta de Morcego 2 & Eugenia speciosa, Cambess. & Myrtaceae & Outros & Arbórea Nativa \\
\hline Fruta pão & Artocarpus altilis, (Parkinson) Fosberg & Moraceae & $\begin{array}{l}\text { Alimentação } \\
\text { Medicinal }\end{array}$ & Arbórea Cultivada \\
\hline Garapubu & Schizolobium parahyba, (Vell.) Blake & Caesalpiniaceae & Outros & Arbórea Nativa \\
\hline Gengibre & Zingiber officinalis, Roscoe & Zingiberaceae & $\begin{array}{l}\text { Alimentação } \\
\text { Medicinal }\end{array}$ & Herbácea \\
\hline Gerânio (malva) & Pelargonium hortorum, LH. Bailey & Geraniaceae & \begin{tabular}{|l|} 
Medicinal \\
ornamental
\end{tabular} & Herbácea \\
\hline Gervão roxo & Stachytarpheta caynenesis, (Rich) Vahl. & Amaranthaceae & Medicinal & Herbácea \\
\hline Gloxínia (boca de lobo) & Sinningia speciosa, Baill. & Gesneriaceae & Ornamental & Herbácea \\
\hline
\end{tabular}


ANEXO G - Listagem Botânica Das Plantas Coletadas Nos Dezenove Quintais Do Saco Do Mamanguá Paraty- RJ.

\begin{tabular}{|c|c|c|c|c|}
\hline Nome Popular & Nome científico & Família & Uso & Hábito \\
\hline Goiaba Branca & Psidium guajava, L. & Myrtaceae & \begin{tabular}{|l} 
Alimentação \\
Medicinal
\end{tabular} & Arbórea Cultivada \\
\hline Goiaba Vermelha & Psidium guajava, L. & Myrtaceae & $\begin{array}{l}\text { Alimentaçã } \\
\text { Medicinal }\end{array}$ & Arbórea Cultivada \\
\hline Grama & Zoysia tenuifolia, Trin & Gramineae & Ornamental & Herbácea \\
\hline Grama & Paspalum notatum, Flüggé & Gramineae & Ornamental & Herbácea \\
\hline Grumixama & Eugenia brasiliensis, Lam & Myrtaceae & Alimentação & Arbórea Nativa \\
\hline Guaco & $\mathrm{NI}$ & $\mathrm{NI}$ & Medicinal & Herbácea \\
\hline Guandu & Cajanus cajan,(L.) Millsp. & Fabaceae & Alimentação & Arbustiva Cultivada \\
\hline Guaraninha & Ervatamia coronaria, Stapf & Apocynaceae & Ornamental & Arbustiva Cultivada \\
\hline Guarana & Tabernamontana cf australis, Müll. Arg. & Apocynaceae & Ornamental e outros & Arbórea Nativa \\
\hline Guaretá & Citharexylum myrianthum, Cham & Verbenaceae & \begin{tabular}{|l|} 
Outros \\
\end{tabular} & Arbórea Nativa \\
\hline Hortelã & Mentha sp & Lamiaceae & Medicinal & Herbácea \\
\hline Hortelã de galinha & Plectrantus sp & Lamiaceae & \begin{tabular}{|l|} 
Medicinal \\
condimentos
\end{tabular} & Herbácea \\
\hline Hortênsia & Hydrangea macrophyla, Ser. & Saxifragaceae & Ornamental & Herbácea \\
\hline Ingá & Inga subnuda, Salzm. ex Benth. & Mimosaceae & Alimentação e outros & Arbórea Nativa \\
\hline Ingá amendoim & Inga sp & Mimosaceae & \begin{tabular}{|l|} 
Outros \\
\end{tabular} & Arbórea Nativa \\
\hline Ingá Cipó & Inga vera, Willd. & Mimosaceae & Alimentação e outros & Arbórea Nativa \\
\hline Ingá Feijão & Inga sp (striata?), Benth. & Mimosaceae & Alimentação outros & Arbórea Nativa \\
\hline Ingá Flecha & Inga edulis, Mart & Mimosaceae & Alimentação e outros & Arbórea Nativa \\
\hline Inhame & Colacasia esculenta, L. Schott. & Araceae & Alimentação & Herbácea \\
\hline Ipê amarelo & Stenolobium status, Seem & Bignoniacea & Ornamental e outros & Arbórea Nativa \\
\hline Ipê amarelo & Tabebuia sp & Bignoniacea & Ornamental e outros & Arbórea Nativa \\
\hline
\end{tabular}


ANEXO G - Listagem Botânica Das Plantas Coletadas Nos Dezenove Quintais Do Saco Do Mamanguá Paraty- RJ.

\begin{tabular}{|c|c|c|c|c|}
\hline Nome Popular & Nome científico & Família & Uso & Hábito \\
\hline Ipê roxo & Tabebuia sp & Bignoniacea & Ornamental e outros & Arbórea Nativa \\
\hline Iris da praia & Neomarica candida, Sprague & Iridaceae & Ornamental & Herbácea \\
\hline Ixora & Ixora coccinea, Linn & Rubiaceae & Ornamental & Herbácea \\
\hline Jaboticaba & Myrciaria cf trunciflora, Berg. & Myrtaceae & Alimentação & Arbórea Cultivada \\
\hline Jaca & Artocarpus integrifolia, L & Moraceae & Alimentação & Arbórea Cultivada \\
\hline Jaca da vermelha & Artocarpus integrifolia, L & Moraceae & Alimentação & Arbórea Cultivada \\
\hline Jacatirão & Miconia sp3 & Melastomataceae & Outros & Arbórea Nativa \\
\hline Jambo & Syzygium malecense, L. & Myrtaceae & $\begin{array}{l}\text { Alimentação } \\
\text { Medicinal }\end{array}$ & Arbórea Cultivada \\
\hline Jambo cera & Syzygium sp & Myrtaceae & Alimentação & Arbórea Cultivada \\
\hline Jardineira & Verbena cf tenera, Spreng & Verbenaceae & Ornamental & Herbácea \\
\hline Jibóia & Scindapsus aureus, Engl. & Araceae & Ornamental & Herbácea \\
\hline Jiló & Solanum gilo, L. & Solanaceae & Alimentação & Herbácea \\
\hline Jissara & Euterpe edulis,Mart. & Arecaceae & Alimentação e outros & Arbórea Nativa \\
\hline Jorgina & Zinnia elegans, Jacq. & Asteracea & Ornamental & Herbácea \\
\hline Jurema cheirosa & Aloysia gratissima, (Gill. Et Hook) Tronc. & Verbenaceae & Ornamental & Herbácea \\
\hline Lágrima de Cristo & Clerodendron thomsonae, Balf. & Verbenaceae & Ornamental & Arbustiva Cultivada \\
\hline Laranja Bahia & Citrus cf sinsensis, (Linn) Osbech. & Rutaceae & $\begin{array}{l}\text { Alimentação } \\
\text { Medicinal }\end{array}$ & Arbustiva Cultivada \\
\hline Laranja Cidra & Citrus medica, Linn & Rutaceae & Alimentação & Arbustiva Cultivada \\
\hline Laranja Cravo & Citrus sp & Rutaceae & Alimentação & Arbustiva Cultivada \\
\hline Laranja Lima & Citrus aurantifolia, Christom. Swing. & Rutaceae & Alimentação & Arbustiva Cultivada \\
\hline Laranja pêra & Citrus of sinensis, (Linn) Osbech. & Rutaceae & $\begin{array}{l}\text { Alimentação } \\
\text { Medicinal }\end{array}$ & Arbustiva Cultivada \\
\hline
\end{tabular}


ANEXO G - Listagem Botânica Das Plantas Coletadas Nos Dezenove Quintais Do Saco Do Mamanguá Paraty- RJ.

\begin{tabular}{|c|c|c|c|c|}
\hline Nome Popular & Nome científico & Família & Uso & Hábito \\
\hline Laranja China & Citrus reticulada & Rutaceae & $\begin{array}{l}\text { Alimentação } \\
\text { Medicinal }\end{array}$ & Arbustiva Cultivada \\
\hline Laranja tangerina & Citrus reticulada & Rutaceae & Alimentação & Arbustiva Cultivada \\
\hline Laranjinha & $\mathrm{NI}$ & $\mathrm{NI}$ & Ornamental & Arbustiva Cultivada \\
\hline Limão Cravo & Citrus limon, (Linn) Burn. & Rutaceae & $\begin{array}{l}\text { Alimentação } \\
\text { Medicinal }\end{array}$ & Arbustiva Cultivada \\
\hline Limão legítimo & Citrus limon, (Linn) Burn. & Rutaceae & Alimentação/Med. & Arbustiva Cultivada \\
\hline Lirio & Belamcanda chinesis, DC. & Iridaceae & Ornamental & Herbácea \\
\hline Lírio amarelo & Hemerocallis flava, Linn & Liliaceae & Ornamental & Herbácea \\
\hline Lírio de paz (branco) & Spathiphyllum wallisi, Regel & Araceae & Ornamental & Herbácea \\
\hline Lírio roxo & Neomarica caerulea, Sprague & Iridaceae & Ornamental & Herbácea \\
\hline Losna & Artemisia vulgaris, $\mathrm{L}$. & Asteracea & Medicinal & Herbácea \\
\hline Maio & $N I$ & $\mathrm{NI}$ & Ornamental & Arbustiva Cultivada \\
\hline Mal me quer & Lantana camara, Linn & Verbenaceae & Ornamental & Herbácea \\
\hline Malacutão & Piper cf aduncum & Piperaceae & Ornamental & Herbácea \\
\hline Malva (geranio) & Pelargonium hortorum, LH. Bailey & Geraniaceae & Ornamental & Herbácea \\
\hline Mamão fêmea & Carica papaya, L. & Caricaceae & $\begin{array}{l}\text { Alimentação } \\
\text { Medicinal }\end{array}$ & Arbustiva Cultivada \\
\hline Mamão macho & Carica papaya, L. & Caricaceae & Alimentação/Medic. & Arbustiva Cultivada \\
\hline Manacá & Brunfelsia uniflora, D. Don. & Solanaceae & Ornamental & Arbustiva Nativa \\
\hline Mandioca brava & Manihot sp & Euphorbiaceae & Alimentação & Arbustiva Cultivada \\
\hline Manga & Mangifera indica, L. & Anacardiaceae & Alimentação & Arbórea Cultivada \\
\hline Manga amarela & Mangifera indica, L. & Anacardiaceae & Alimentação & Arbórea Cultivada \\
\hline Manga rosa & Mangifera indica, L. & Anacardiaceae & Alimentação & Arbórea Cultivada \\
\hline
\end{tabular}


ANEXO G - Listagem Botânica Das Plantas Coletadas Nos Dezenove Quintais Do Saco Do Mamanguá Paraty- RJ.

\begin{tabular}{|c|c|c|c|c|}
\hline Nome Popular & Nome científico & Família & Uso & Hábito \\
\hline Mangue do mato & Rapanea guyanensis, Aubl. & Myrsinacea & Outros & Arbórea Nativa \\
\hline Manjericão & Ocimum micranthum, Willd. & Lamiaceae & Condimento & Herbácea \\
\hline Maracujá & Passiflora sp & Passifloriaceae & \begin{tabular}{|l} 
Alimentação \\
Medicinal
\end{tabular} & Cipo \\
\hline Maravilha & Mirabilis jalapa, Linn & Nyctaginaceae & Ornamental & Herbácea \\
\hline Marcela & Achyrocline satureoides, (Lam) D.C. & Asteracea & Medicinal & Herbácea \\
\hline Margarida & Chrisanthemum leucanthemum, Linn & Asteracea & Ornamental & Herbácea \\
\hline Margaridinha & $\begin{array}{l}\text { Chrisanthemum anethifolium, Brouss. Ex } \\
\text { Willd. }\end{array}$ & Asteracea & Ornamental & Herbácea \\
\hline Maria Mole & Aegiphila sellowiana, Cham & Verbenaceae & Outros & Arbórea Nativa \\
\hline Maria mole & Guapira opposita (Vell.) Brenan & Nyctaginaceae & Outros & Arbórea Nativa \\
\hline Maria Preta & Vernonia scorpioides, & Asteracea & Medicinal & Arbustiva Nativa \\
\hline Melancia & $\mathrm{NI}$ & $\mathrm{NI}$ & Alimentação & Herbácea \\
\hline Melão & $\mathrm{NI}$ & $\mathrm{NI}$ & Alimentação & Herbácea \\
\hline Milho & Zea mays, L. & Gramineae & Alimentação & Herbácea \\
\hline Mimo amarelo & Hibiscus rosa-sinenses, Linn & Malvaceae & Ornamental & Arbustiva Cultivada \\
\hline Mimo branco & Hibiscus syriacus,L. & Malvaceae & Ornamental & Arbustiva Cultivada \\
\hline Mimo crespo vermelho & Hibiscus rosa-sinenses, Linn & Malvaceae & Ornamental & Arbustiva Cultivada \\
\hline Mimo de cerca & Malvaviscus arboreus, Cav. & Malvaceae & Ornamental & Arbustiva Cultivada \\
\hline Mimo folha verde e bca & Hibiscus rosa-sinenses, Linn & Malvaceae & Ornamental & Arbustiva Cultivada \\
\hline Mimo rosa & Hibiscus rosa-sinenses, Linn & Malvaceae & Ornamental & Arbustiva Cultivada \\
\hline Mimo roxo & Ipomea carnea & Convolvulaceae & Ornamental & Arbustiva Cultivada \\
\hline Mimo vermelho & Hibiscus rosa-sinenses, Linn & Malvaceae & Ornamental & Arbustiva Cultivada \\
\hline Monjolo (Pau jacaré) & Piptadenia gonoacantha,(Mart.) Macbr. & Mimosaceae & Outros & Arbórea Nativa \\
\hline
\end{tabular}


ANEXO G - Listagem Botânica Das Plantas Coletadas Nos Dezenove Quintais Do Saco Do Mamanguá Paraty- RJ.

\begin{tabular}{|c|c|c|c|c|}
\hline Nome Popular & Nome científico & Família & Uso & Hábito \\
\hline Mostarda & Brassica juncea,(L.) Czern. & Brassicaceae & Alimentação & Herbácea \\
\hline Murta da branca & Largestomia cf indica, L. & Lytraceae & Ornamental & Arbustiva Cultivada \\
\hline Murta roxa & Lagerstomia cf indica, L. & Lytraceae & Ornamental & Arbustiva Cultivada \\
\hline NI 3 & Eucharis grandiflora, Planch. \& Linden & Amaryllidaceae & Ornamental & Herbácea \\
\hline $\mathrm{NI} 1$ & Macherium nyctitans, (Vell.) J. F. Macbr & Mimosaceae & Outros & Arbórea Nativa \\
\hline $\mathrm{NI} 8$ & Alpinia purpurata, K.Schum. & Zingiberaceae & Ornamental & Cipo \\
\hline $\mathrm{NI} 9$ & Canna cf glauca, Linn & Cannaceae & Ornamental & Arbórea Cultivada \\
\hline NI 10 & $\begin{array}{l}\text { Alpinia zerumbet, (Pers.) B. L. Burt \& } \\
\text { R.M. Sm. }\end{array}$ & Zingiberaceae & Ornamental & Herbácea \\
\hline NI 11 & Miconia sp1 & Melastomataceae & Outros & Arbórea Nativa \\
\hline NI 12 & Miconia sp2 & Melastomataceae & Outros & Herbácea \\
\hline $\mathrm{NI} 13$ & Tibouchina cf granulosa, (Desr.) Cogn. & Melastomataceae & Outros & Arbórea Nativa \\
\hline $\mathrm{NI} 14$ & Leandra, sp & Melastomataceae & Outros & Arbórea Nativa \\
\hline $\mathrm{NI} 15$ & Solanum cf argentum & Solanaceae & Ornamental e outros & Arbórea Nativa \\
\hline $\mathrm{NI} 2$ & Calliandra brevipes, Benth. & Mimosaceae & Ornamental & Herbácea \\
\hline $\mathrm{NI} 4$ & Erythroxylum sp & Erythroxylaceae & Outros & Herbácea \\
\hline $\mathrm{NI} 5$ & Oxalis sp & Oxalidaceae & Ornamental & Herbácea \\
\hline $\mathrm{NI} 6$ & Ipomea pinnata & Convolvulaceae & Ornamental & Epifita \\
\hline $\mathrm{NI} 7$ & Pedilanthus tithymaloides & Euphorbiaceae & Ornamental e outros & Arbórea Cultivada \\
\hline Novalgina & Pfaffia cf glomerata & Amaranthaceae & Medicinal & Herbácea \\
\hline Olho de boneca & Dendrobium nobile, Lindl. & Orchidaceae & Ornamental & Epifita \\
\hline Onze Horas & Portulaca oleracea, Linn & Portulacaceae & Ornamental & Herbácea \\
\hline Orquídea & NI & Orchidaceae & Ornamental & Epifita \\
\hline
\end{tabular}


ANEXO G - Listagem Botânica Das Plantas Coletadas Nos Dezenove Quintais Do Saco Do Mamanguá Paraty- RJ.

\begin{tabular}{|c|c|c|c|c|}
\hline Nome Popular & Nome científico & Família & Uso & Hábito \\
\hline Orquídea Pingo de ouro & Oncidium varicosum, Lindl. & Orchidaceae & Ornamental & Epifita \\
\hline Palmeirinha 1 & $\begin{array}{l}\text { Dypsis lutescens, (H. Wendl.) Beentje \& } \\
\text { J. Dransf. }\end{array}$ & Arecaceae & Ornamental & Arbustiva Cultivada \\
\hline Palmeirinha 2 & $\begin{array}{l}\text { Raphis excelsa, (Thunb.) A. Henry ex } \\
\text { Rehder }\end{array}$ & Arecaceae & Ornamental & Arbustiva Cultivada \\
\hline Pampulha & Hibiscus cf pernambucenses & Malvaceae & Ornamental & Arbustiva Cultivada \\
\hline Paraguaia & Iresine herbstii, Hook & Amaranthaceae & Ornamental & Herbácea \\
\hline Peperômia 1 & Peperomia sandersii, C. DC. & Piperaceae & Ornamental & Herbácea \\
\hline Peperômia 2 & Peperomia scandens, Ruiz \& Pav. & Piperaceae & Ornamental & Herbácea \\
\hline Pepino & Cucumis sativus & Cucurbitaceae & Alimentação & Herbácea \\
\hline Perpétua & Gomphrena globosa, Linn & Amaranthaceae & Ornamental & Herbácea \\
\hline Piao do roxo & Jatropha gossypifolia, L. & Verbenaceae & Medicinal & Herbácea \\
\hline Piloteira 1 & Cyphomandra diploconos, (Mart) Sendtn. & Solanaceae & Outros & Arbórea Nativa \\
\hline Piloteira 2 & Aureliana fasciculata,(Vell.) Sendtn & Solanaceae & Outros & Arbustiva Nativa \\
\hline Piloteira 3 & Solanum pseudoquina, A. St. - Hill & Solanaceae & Outros & Arbórea Nativa \\
\hline Pimena malagueta & Capsicum frutecenses, & Solanaceae & Condimento & Herbácea \\
\hline Pimenta botão & Capsicum sp & Solanaceae & Condimento & Herbácea \\
\hline Pimenta cambari & Capsicum sp & Solanaceae & Condimento & Herbácea \\
\hline Pimenta do reino & Piper nigrum, L. & Piperaceae & Condimento & Cipo \\
\hline Pimenta doce & Capsicum sp & Solanaceae & Alimentação & Herbácea \\
\hline Pimentão & Capsicum annum, L. & Solanaceae & Alimentação & Herbácea \\
\hline Pimentinha & Erythroxylum buxus, Peyr. & Erythroxylaceae & Ornamental e outros & Arbustiva Nativa \\
\hline Pindá & Allamanda cathartica, L. & Apocynaceae & Ornamental & Herbácea \\
\hline
\end{tabular}


ANEXO G - Listagem Botânica Das Plantas Coletadas Nos Dezenove Quintais Do Saco Do Mamanguá Paraty- RJ.

\begin{tabular}{|c|c|c|c|c|}
\hline Nome Popular & Nome científico & Família & Uso & Hábito \\
\hline Piperaceae & Piper sp & Piperaceae & Ornamental & Herbácea \\
\hline Pipoca & NI & $\mathrm{NI}$ & Ornamental & Arbustiva Cultivada \\
\hline Pita & Agave americana,L. & Agavaceae & Ornamental & Arbustiva Cultivada \\
\hline Pitanga & Eugenia uniflora, L. & Myrtaceae & Alimentação Med. & Arbórea Cultivada \\
\hline Pixirica 1 & Miconia cf dodecandro, (Desr.) Cogn & Melastomataceae & Outros & Arbórea Nativa \\
\hline Pixirica 2 & Clidemia sp & Melastomataceae & Ornamental & Arbórea Nativa \\
\hline Planta veludo & $\begin{array}{l}\text { Ruellia makoyana, Hort ex Barclay \& F. } \\
\text { T. Hubb }\end{array}$ & Acanthaceae & Ornamental & Herbácea \\
\hline Poejo & Mentha pulegium, L. & Lamiaceae & Medicinal & Herbácea \\
\hline Prateadinha & $\begin{array}{llll}\begin{array}{l}\text { Chamaeranthemum venosum, } \\
\text { Forster \& Lor.B. Sm }\end{array} & \text { B. } \\
\end{array}$ & Acanthaceae & Ornamental & Herbácea \\
\hline Pupunha & Bractis gasipaes, Kunth & Arecaceae & Alimentação & Arbórea Cultivada \\
\hline Quebra pedra & Chamaesyce prostrata, (Aiton) Small & Euphorbiaceae & Medicinal & Herbácea \\
\hline Quiabo & Hibiscus esculentus, L. & Malvaceae & Alimentação & Herbácea \\
\hline Rabo de burro & Sedum morganiuanum, Walth. & Crassulaceae & Ornamental & Herbácea \\
\hline Rabo de gato & Acalypha hispida, Willd. & Euphorbiaceae & Ornamental & Herbácea \\
\hline Rabo de gato rasteiro & Acalypha reptans, Sw. & Euphorbiaceae & Ornamental & Herbácea \\
\hline Renda portuguesa & Davallia fejeensis, Hook. & Davalliaceae & Ornamental & Herbácea \\
\hline Romã & Punica granatum, L. & Punicaceae & $\begin{array}{l}\text { Alimentação } \\
\text { Medicinal }\end{array}$ & Arbórea Cultivada \\
\hline Rosa branca & Rosa sp & Rosaceae & Ornamental & Herbácea \\
\hline Rosa do lodo & Pistia stratiotes, Linn. & Araceae & Ornamental & Herbácea \\
\hline Sabugueiro & Sambucus nigra, L. & Caprifoliaceae & Medicinal & Arbustiva Cultivada \\
\hline Saia de cutia & Stifftia sp & Asteracea & Ornamental & Herbácea \\
\hline
\end{tabular}


ANEXO G - Listagem Botânica Das Plantas Coletadas Nos Dezenove Quintais Do Saco Do Mamanguá Paraty- RJ.

\begin{tabular}{|c|c|c|c|c|}
\hline Nome Popular & Nome científico & Família & Uso & Hábito \\
\hline Saião & Kalanchoe sp & Crassulaceae & Medicinal & Herbácea \\
\hline Saiãozinho & Kalanchoe sp & Crassulaceae & Medicinal Ornam. & Herbácea \\
\hline Salsinha & $\begin{array}{l}\text { Petroselinum crispum,(Mill.) Nyman ex } \\
\text { A.W. Hill }\end{array}$ & Lamiaceae & Condimento & Herbácea \\
\hline Samabaia de metro & Nephrolepis cordifolia, Presl. & Davalliaceae & Ornamental & Herbácea \\
\hline Samambaia & Nephrolepis sp & Davalliaceae & Ornamental & Herbácea \\
\hline São paulo crespo & Portulaca grandiflora, Hook & Portulacaceae & Ornamental & Herbácea \\
\hline São paulo liso & Portulaca oleraceae,Linn. & Portulacaceae & Ornamental & Herbácea \\
\hline Saputiaba & Bredemeyra sp & Poligalaceae & Outros & Arbórea Nativa \\
\hline Seis meses & \begin{tabular}{|lll}
$\begin{array}{l}\text { Euphorbia } \\
\text { Klotzsch }\end{array}$ & pulcherrima, Willd. Ex \\
\end{tabular} & Euphorbiaceae & Ornamental & Arbustiva Cultivada \\
\hline Simbiíba & $\begin{array}{l}\text { Licania cf octandra, (Hofmg. Ex R. \& S>) } \\
\text { Kuntze }\end{array}$ & Chrysobalanaceae & Outros & Arbórea Nativa \\
\hline Suspiro & Celosia argenta, Linn. & Amaranthaceae & Ornamental & Herbácea \\
\hline Taioba & Alocasia macrorhiza, Schott & Araceae & $\begin{array}{l}\text { Alimentação } \\
\text { ornamental }\end{array}$ & Herbácea \\
\hline Tanssagem & Plantago major, L. & Plantaginaceae & Medicinal & Herbácea \\
\hline Tapete 1 & Solenostemum scutellarioides, L. Codd. & Lamiaceae & Ornamental & Herbácea \\
\hline Tapete 2 & Episcia cupreata, Haust. & Gesneriaceae & Ornamental & Herbácea \\
\hline Tarumã & Citharexylum myrianthum, Cham & Verbenaceae & Outros & Arbórea Nativa \\
\hline Terramicina & Pfaffia sp & Amaranthaceae & Medicinal & Herbácea \\
\hline Timbuíba & $\begin{array}{l}\text { Balizia of pedicelaris, (DC) Barneby \& } \\
\text { JW Grimes }\end{array}$ & Mimosaceae & Outros & Arbórea Nativa \\
\hline Timbupeva & $\mathrm{NI}$ & $\mathrm{NI}$ & Outros & Arbórea Nativa \\
\hline
\end{tabular}


ANEXO G - Listagem Botânica Das Plantas Coletadas Nos Dezenove Quintais Do Saco Do Mamanguá Paraty- RJ.

\begin{tabular}{|l|l|l|l|l|}
\hline Nome Popular & Nome científico & Família & Uso & Hábito \\
\hline Tipo de jambo & Syzygium cf cuminii, L. Skeels. & Myrtaceae & Outros & Arbórea Cultivada \\
\hline Tomate & Solanum lycopersicum, L. & Solanaceae & Alimentação & Herbácea \\
\hline Tomate bucho de bagre & Solanum sp & Solanaceae & Alimentação & Herbácea \\
\hline Trapoeraba & Tradescantia pallida, (Rose) D.R. Hunt & Commelinaceae & Ornamental & Herbácea \\
\hline Trepadeira amarela & Senecio cf confusus & Asteracea & Ornamental & Cipo \\
\hline Trep. Flor de S. Miguel & Petrea subserrata, Cham. & Verbenaceae & Ornamental & Cipo \\
\hline Trevo roxo & Oxalis sp & Oxalidaceae & Ornamental & Herbácea \\
\hline Urucoum & Bixa orellana, L & Bixaceae & Condimento & Arbórea Cultivada \\
\hline Uva & Vitis sp & Vitaceae & Alimentação & Herbácea \\
\hline Valmora & Solanum americanum, Mill. & Solanaceae & Medicinal & Herbácea \\
\hline Vassoura & Baccharis semiserrata, Baker & Asteracea & Outros & Herbácea \\
\hline Vento levou & NI & NI & Ornamental & Herbácea \\
\hline Verdiana & Caladium $x$ hortulanum, Birdsey & Araceae & Ornamental & Herbácea \\
\hline Violeta & Saintpaulia ionantha, H. Wendl. & Gesneriaceae & Ornamental & Herbácea \\
\hline Xixá & Alchornea glandulosa, Poepp. & Euphorbiaceae & Outros & Arbórea Nativa \\
\hline
\end{tabular}




\section{REFERÊNCIAS BIBLIOGRÁFICAS}

ADAMS, C. Caiçaras na Mata Atlântica: pesquisa científica versus planejamento e gestão ambiental. São Paulo: Annablume: FAPESP, 2000. 337 p.

ADAMS, C. Identidade caiçara: exclusão histórica e sócioambiental. In: ALBUQUERQUE, U. P. et al (Org.). Atualidades em etnobiologia e etnoecologia. Recife: Sociedade Brasileira de Etnobiologia e Etnoecologia, 2002. 151p.

ALTIERI, M. Agroecologia: a dinâmica produtiva da agricultura sustentável. 2. ed. Porto Alegre: Editora da Universidade - UFRGS, 2000. $110 p$.

AMBRÓSIO, L.A.; PERES, F.C.; SALGADO, J.M. Diagnóstico dos produtos do quintal na alimentação das famílias rurais: microbacia D'Água F, Vera Cruz. Informações Econômicas, v. 26, n. 7, p.27 - 39, 1996.

AMOROZO, M.C.de M. Alimentação em um bairro pobre de Manaus, Amazonas. Acta Amazônica, v. 11, n.3, Supl. p. 43, 1981.

BEGOSSI, A.; HANAZAKI, N.; SILVANO, R.A.M. Ecologia humana, etnoecologia e conservação. In: AMOROZO, M.C.M.; MING,L.C.; SILVA,S.M.P. (Org.). Métodos de coleta de dados em etnobiologia e etnoecologia e disciplinas correlatas. Rio Claro: UNESP- CNPq, 2002. p. 93-128.

BECKER, H.S. Métodos de pesquisa em ciências sociais. 4. ed. São Paulo: Editora Hucitec, 1999. $178 \mathrm{p}$.

BRANDÃO, C.R. Plantar, Colher, Comer. Rio de Janeiro: Edições Graal, 1981. v. 1 
BRANDÃO, C.R. Participação da pesquisa no trabalho popular. In: BRANDÃO, C. R (Org.). Repensando a pesquisa participante. São Paulo: Editora Brasiliense, 1999. p.223- 251.

BRANDÃO, C.R. Identidade e etnia: construção da pessoa e resistência cultural. São Paulo: Editora Brasiliense, 1986. $170 \mathrm{p}$.

BORRINI-FEYRABEND, G. Manejo participativo de áreas protegidas: Adaptando o Método ao Contexto. Gland, Suiça: União Mundial para a Natureza, 1997. 67 p.

BRITO, M.C.W. Unidades de conservação: intenções e resultados. São Paulo: Annablume: FAPESP, 2000. $230 \mathrm{p}$.

BRITTO, R.C. Modernidade e tradição: construção da identidade social dos pescadores de Arrail do Cabo, RJ. Rio de Janeiro: EDUFF, 1995.

CALVENTE, M. del C.M.H. No território do azul marinho. A busca do espaço caiçara. São Paulo, 1992. 173 p. Dissertação (Mestrado). Faculdade de Filosofia, Letras e Ciências Humanas, Universidade de São Paulo.

CANDIDO, A. Os Parceiros do Rio Bonito: Estudo sobre o caipira paulista e a transformação dos seus meios de vida. São Paulo: Livraria Duas Cidades, 1987. 282 p.

CASTRO, E. Território, biodiversidade e saberes. In: DIEGUES, A. C. (Org.). Etnoconservação: novos rumos para a proteção da natureza. São Paulo: HUCiTEC/USP, NUPAUB, 2000. p.165-182.

CONSÓRCIO MATA ATLÂNTICA, Reserva da biosfera Mata Atlântica. Campinas: Universidade Estadual de Campinas. Plano de Ação: Referências Básicas. 1992 . 101 p. v. 1

CRUZ, G. L. Dicionário das plantas úteis do Brasil 2a. ed. Rio de Janeiro: Civilização Brasileira, 1982. $599 \mathrm{p}$. 
CUNHA, M.M.C.; ALMEIDA, M.W.B. Populações tradicionais e conservação. In: CAPOBIANCO, J. P. R. et al. (Org.) Biodiversidade na Amazônia: avaliação e ações prioritárias para a conservação, uso sustentável e repartição de benefícios. São Paulo: Editora Estação Liberdade e Instituto Sócio Ambiental, 2000.

DIEGUES, A.C.; NOGARA P.J. O Nosso lugar virou parque: estudo sócio- ambiental do Saco do Mamanguá- Paraty-RJ. São Paulo: NUPAUB/USP, 1994. 187 p.

DIEGUES, A.C.; ARRUDA R.S.V.(Org.) Saberes tradicionais e biodiversidade no Brasil. Brasília: Ministério do Meio Ambiente; NUPAUB/USP, 2001. 176 p. (Biodiversidade,4).

FELIPIM, A. P.; Resende, R. U.; RIBEIRO, R.J. Agricultura de pousio e controle ambiental In: DIEGUES \& VIANA (Org.). Comunidades tradicionais e manejo dos recursos naturais da Mata Atlântica. São Paulo: USP, NUPAUB; USP, LASTROP-ESALQ. 2000. p.111 - 119.

FERREIRA, L. da C.; SIVIERO, O. S. de; CAMPOS, S. V. de; et al. Conflitos sociais em áreas protegidas no Brasil: Moradores, Instituições e Ongs no Vale do Ribeira e Litoral Sul de São Paulo. São Paulo: 2000. (no prelo)

FREIRE, P. Criando métodos de pesquisa alternativa: aprendendo a fazê-la melhor através da ação. In: BRANDÃO, C. R. (Org.). Pesquisa participante. $7^{0}$ ed. São Paulo: Editora Brasilense, 1988. 211p.

GUIMARÃES, R.G., "A importância de quintais domésticos com relação à alimentação e renda familiares." Rio Claro, 1998: 82 p. Monografia (Graduação). Instituto de Biociências, Universidade Estadual Paulista "Júlio de Mesquita Filho".

GUITIÉRREZ, F. Educação comunitária e desenvolvimento sócio - político. In: GADOTTI, M. e GUITIÉRREZ, F. (Org.). Educação comunitária e economia popular. São Paulo: Editora Cortez, 1993. cap. 2. p $23-33$.

HANAZAKI, N. Ecologia Caiçara: uso de recursos e dieta. Campinas-SP, 2001. 193p. Tese (Doutorado). Instituto de Biologia, Universidade de Campinas. 
HANAZAKI, N.; LEITÃO-FILHO H. de F.; BEGOSSI, A. Uso de recursos na Mata Atlântica: o caso da Ponta do Almada (Ubatuba, Brasil). Interciência, v.25, n. 3, maio - junho, 2000.

KEMPERS, M.O., Ecological Planning in South- East Brazil, 1993. 116 p. Thesis (Ph. D.). Department of Forestry, Department of Ecological and Department of Enviromental Planning of the Agriculture, University of Wageningen.

LEITÃO FILHO, H. de F., (Coord.) Ecologia da Mata Atlântica em Cubatão (SP). CampinasSP: Editora da UNICAMP, 1993. $173 \mathrm{p}$.

LEEUWEN van J. O pomar Caseiro na região de Manaus, amazonas, um importante sistema agroflorestal tradicional. In: ENCONTRO DA SOCIEDADE BRASILEIRA DE PRODUÇÃO, 2,. LONDRINA, PR, 1995. Actas Londrina: IAPAR,. 1995 p. 180 - 189.

LIMA, R.M.B. Descrição, composição e manejo dos cultivos mistos de quintal na várzea da "Costa do Caldeirão", Iranduba, AM. Manaus, 1994. 264 p. Dissertação (Mestrado). Programa de Pós - Graduação em Biologia Tropical e Recursos Naturais, Instituto Nacional de Pesquisa da Amazônia.

LOK, R. La Función Insustituble de los Huertos Caseros. Agroforesteria en Las Americas, v.3, n. $9 / 10$, p. $5,1996$.

LOK, R. El Huerto casero tropical tradicional em América Central. In: LOK, R. (Ed.) Huertos Tradicionales de América Central: características, beneficios e importancia, desde um enfoque multidisciplinario. Turrialba, Costa Rica: CATIE/AGUILA/IDR/ETC Andes, 1998 a. p. 7 - 28.

LOK, R. Introdución a los huertos caseros tradicionales tropicales. Turrialba, Costa Rica: CATIE/GTZ, (Módulo de Enseñanza Agroflorestal, n.3) 1998 b. 156 p.

LOK, R.; MENDEZ, E. El uso del ordenamiento local del espacio para una classificación de huertos na Nicaragua. In: LOK, R. (Ed.) Huertos Tradicionales de América Central: 
características, beneficios e importancia, desde um enfoque multidisciplinario. Turrialba, Costa Rica: CATIE/AGUILA/IDR/ETC Andes, 1998. p 129-149.

LORENZI, H.; Souza, H.M. Plantas ornamentais no Brasil: Arbustivas, herbáceas e trepadeiras. 2 ed. Nova Odessa- SP: Instituto Plantarum, 1999. 1088 p.

LORENZI, H., Arvores brasileiras : Manual de Identificacâo e Cultivo de Plantas Arbóreas Nativas do Brasil São Paulo : Plantarum, 1992. $351 \mathrm{p}$

LORENZI, H., Palmeiras no Brasil: nativas e exóticas Nova Odessa - SP: Plantarum, 1996. $303 p$.

MALDONADO, S.C. Pescadores do mar. São Paulo: Editora Ática,. 1986. 77 p. (Série princípios).

MANSANO, C.F. Do tempo dos antigos ao tempo de hoje: caiçaras de Cambury entre a terra e o mar. Campinas, 1998. 174p. Dissertação (Mestrado). Faculdade de Educação, Universidade Estadual de Campinas.

MARQUES, J.G.W. Pescando Pescadores. Etnoecologia abrangente no baixo São Francisco alagoano. São Paulo: NUPAUB-USP, 1995. 127 p.

MARQUES, M.C.M. (Org.) Mapeamento da cobertura vegetal e listagem das espécies ocorrente na área de proteção ambiental de Cairuçu, município de Paraty, RJ.. Rio de Janeiro: Jardim Botânico, 199796 p. (Série Estudos e Contribuições).

MARSH R.; HERNANDEZ I. El Papel del Huerto Casero en la economia del hogar: casos de Honduras y Nicaragua. Agroforesteria en Las Americas, v. 3, n. 9/ 10, 1996. p. 35 - 41.

MARTIN, G.J. Ethnobotany a methods manual: A people and plants conservation manual, London: Chapman and Hall, 1995. v. 1, 268 p. 
MICHON, G.;F.MARY Transforming traditional home gardens and related systems in West Java (Bogor) and West Sumatra (Maninjau). S.L.: In: K. LANDAUER; M. BRAZIL (Ed.). Tropical homegardens. United Nations University Press, 1990. p. 110 - 135.

MURRIETA, R.S.S. Dialética do sabor: alimentação, ecologia e vida cotidiana. Revista de Antropologia, v. 44, n.2, p 53 - 75, 2001.

MUSSOLINI, G. Ensaios de antropologia indígena e caiçara. In: EDGARD CARONE (Coord.). Rio de Janeiro: Ed. Paz e Terra, 1980. 228 p.

NAIR, P.K.R. An Introduction to agroforestry. The Netherlands: Kluwer Academic Published, 1993. 499p.

OKIGBO, B.N. Home gardens in tropical Africa. In: LANDAUER K.; BRAZIL, M. (Ed.). Tropical home gardens. Tokyo, Japón: United Nations Press. 1990. p. 53 -72.

OLIVEIRA, R. de; LIMA, D.F.; SAMPAIO, P. D. et al, Roça caiçara: um sistema "primitivo"autosustentável. Ciência Hoje, v. 18, n. 104, p. 45 - 51, 1994.

OLIVEIRA, S.P. THÉBAUD-MONY, A. Estudo do consumo alimentar: em busca de uma abordagem multidisciplinar. Revista de Saúde Pública, v.2, n. 31, p. 201-208, 1997.

OLIVEIRA, V.G. Educação ambiental e manejo de recursos naturais em área de proteção ambiental. Piracicaba, 2002. 117p. Dissertação (Mestrado). Escola Superior de Agricultura Luiz de Queiroz, Universidade de São Paulo.

PACHECO, M.E.L. Sistemas de produção: uma perspectiva de gênero. In: WORKSHOP GÊNERO, DEMOCRACIA E POLÍTICAS PÚBLICAS - CONSTRUINDO REFERÊNCIAS PARA A POLÍTICA DE ATUAÇÃO DAS ONGS BRASILEIRAS. Anais Rio de Janeiro: Ong's Brasileiras, 1996 p. 28 - 36.

PELTO, G.H; VARGAS, L. A. Introduction: dietary change and nutrition. Ecology of Food and Nutrition, v.27, p. 159-161, 1992. 
POSEY, D.A. Interpreting and apllying of indigenous concepts: what is necessary to learn from the natives? In: REDFORD , K. H.; PADOCH, C. (Ed). Conservation of Neotropical Forests: working from traditional resource use. New York: Columbia University Press, 1992. p. $21-34$.

RIBEIRO, D. 0 povo brasileiro: a formação e o sentido do Brasil. São Paulo: Companhia das Letras, $1995.470 \mathrm{p}$.

RODRIGUES,C.L. Limites do Consenso: territórios polissêmicos na Mata Atlântica e a gestão ambiental participativa. São Paulo, 2000. 197p.Tese (Doutorado). Faculdade de Filosofia, Letras e Ciências Humanas, Universidade de São Paulo.

SANCHES, R.A. Caiçaras e a Estação Ecológica de Juréia- Itatins (Litoral sul-São Paulo): uma abordagem etnográfica e ecológica para o estudo da relação homem- meio ambiente. São Paulo, 1997. 209p. Dissertação (Mestrado). Instituto de Biociências, Universidade de São Paulo.

SARAGOUSSI, M.; MARTEL, J.H.I. ; RIBEIRO, G.A. Comparação na composição de quintais de três localidades de terra firme do Estado do Amazonas. In POSEY, D. A.; OVERAL, W. L. (Org.) Ethnobiology: implications and applications. Proceedings of the first International Congress of Ethnology. Belém- PA: 1990. v. 1. p. 295-301.

SCHIMDT, C.B. Lavoura Caiçara. Documentário da vida rural. Rio de Janeiro: Ministério da Agricultura - Serviço de informação Agrícola, 1958. 78 p.

SILVA, O.S. O Turismo em Parati: sob a ótica do caiçara da praia do Sono. Presidente Prudente, 2001. 96p. Dissertação (Mestrado). Faculdade de Ciência e Tecnologia, Universdade Estadual Paulista "Júlio Mesquita Filho".

SILVA, P.P.V. Sistemas agroflorestais para recuperação de matas ciliares. Piracicaba, 2002. 110p. Dissertação (Mestrado). Escola Supeior de Agricultura "Luiz de Queiroz", Universidade de São Paulo.

SIQUEIRA, P. Genocídio dos Caiçaras. São Paulo: Ohno; M.; Guaneli, I. (Ed.) 1984.78 p. 
Brasil. Leis, diretrizes, etc. Lei 9.985 de 18 de julho de 2000. Diário Oficial. 01 de agosto de 2000. Vetos da Presidência da República ao Projeto de Lei aprovado pelo Congresso Nacional Conselho Nacional da Reserva da Biosfera da Mata Atlântica. Secretaria do estado do Meio Ambiente do Estado de São Paulo e do Instituto Florestal de São Paulo.

THIOLLENT, M. Notas para o debate sobre pesquisa-ação. In: BRANDÃO, C. R. (Org.). Pesquisa Participante. São Paulo: Editora Brasiliense. 1984. p. 82- 103.

TUAN, Yi- Fi Topofilia: um estudo da percepção, atitudes e valores. São Paulo: Editora Difel, 1974. $212 \mathrm{p}$.

TUAN, Yi- Fi Espaço e Lugar: a perspectiva da experiência. São Paulo: Difusão editorial Difel, 1983. 247p.

VIANA, V. M.; DUBOIS, J.C.L.; ANDERSON, A. Manual Agroflorestal para a Amazônia. Rio de Janeiro: REBRAF, 1996. v.1. 228 p.

VIANA, V.M.; MATOS J.C. DE S.; AMADOR D.B. Sistemas Agroflorestais e Desenvolvimento Rural Sustentável no Brasil. In: CONGRESSO DE CIÊNCIA DO SOLO, 26, Rio de Janeiro:. Anais Rio de Janeiro: s.ed., 1997. p.114 - 121.

VIANA, V.M. Envolvimento Sustentável e Conservação das Florestas Brasileiras. In: DIEGUES; VIANA (Org.). Comunidades tradicionais e manejo dos recursos naturais da Mata Atlântica. São Paulo: USP, NUPAUB; USP, LASTROP-ESALQ. 2000. 273 p.

VÍQUEZ ET AL. Caracterización del huerto mixto tropical "La Asunción" Masatepe, Nicaragua. Agorforestería en las Américas, v.1, n. 1/2, 1994.

WEID, J. M. von. Metodologia de diagnóstico rápido participativo. In: KAUSMEYER, A.; RAMALHO, L. (Org.) Introdução a metodologia participativa: um guia prático. Recife: SACTES-DED, 1995. p.143 - 156. 